\title{
Mobilização leucocitária: controle endógeno e efeitos de xenobióticos
}

Tese apresentada à Faculdade de Ciências Farmacêuticas da Universidade de São Paulo para a obtenção do Título de Professor Livre-Docente junto ao Departamento de Análises Clínicas e Toxicológicas.

São Paulo

2006 
Aos meus pais, pelo esforço incondicional dedicado à minha educação

Ao Prof. João Garcia Leme, por ter me ensinado a fazer ciência

Ao Pedro, por estar sempre ao meu lado

À Luisa e ao Arthur, por me fazerem feliz 
Agradeço de coração a todos os amigos que, de forma direta ou indireta, contribuíram para minha carreira científica. Em especial a:

Dra. Ana Campa

Dra. Ana Marisa C. Tavassi

Dr. Benjamim Eurico Mallucelli

Dra. Catarina de Fátima P. Teixeira

Dra. Celina Lotufo

Dra. Denise V. Tambourgi

Dra. Dulcinéia Saes Parra Abdalla

Dr. Edson Antunes

Dr. Gilberto De Nucci

Dr. Jorge Mario Ferreira Junior

Dra. Mônica Lopes Ferreira

Dr. Oswaldo Sant'anna

Dra. Paulina Sannomiya

Dra. Primavera Borelli

Dra. Regina Pekelman Markus

Dra. Suzana Beatriz Veríssimo de Mello

Dra. Silvia Berlanga de Moraes Barros

Dra. Yara Cury

Dr. Wothan Tavares de Lima

Dra. Zuleica Bruno Fortes

Dra. Zulma Ferreira

Aos docentes do Departamento de Análises Clínicas e Toxicológicas da Faculdade de Ciências Farmacêuticas USP.

Aos meus alunos de Iniciação Científica e Pós-Graduação: Alexandre Ferreira, Cristina Hebeda, Danielle M.H. Cavalcanti, Emerson Botelho, Julyana Furokawa, Leilane Barboza, Suéllen C.V. Moreira, Sandra M.D. Macedo.

À Elaine Midori Ychico e Jorge Alves de Lima da Secretaria de PósGraduação.

Às secretárias Ana Maria Dias Danta, Carla de Souza, Edna Batista Lima, Maria Auxiliadora de Lima, Maria Roseli Ramos, Márcia C. Caramico, Sueli Providelo.

Às auxiliares de Laboratório Dalva C. Moura, Helena M.S. de Francisco, Irene M. Gouveia, Luzia Valderrama e Maria Lúcia Gomes.

À equipe do Biotério de Criação e Experimentação da FCF/IQ.

À FAPESP e ao CNPq pelos auxílios financeiros e bolsas concedidos. 


\section{SUMÁRIO}

Pág.

$\begin{array}{ll}\text { 1. RESUMO } & 01\end{array}$

$\begin{array}{ll}\text { 2. SUMMARY } & 02\end{array}$

3. INTRODUÇÃO 03

3.1 Mobilização leucocitária 03

3.1.1 Interação leucócito-endotélio $\quad 04$

3.2 Controle endógeno da mobilização leucocitária 10

$\begin{array}{ll}\text { 3.2.1 Glicocorticóides endógenos } & 10\end{array}$

3.2.2 Óxido Nítrico 16

3.3 Efeitos de xenobióticos sobre a mobilização leucocitária 24

3.3.1 Compostos fenólicos derivados do metabolismo do benzeno 24

4. REFERÊNCIAS BIBLIOGRÁFICAS 33

5. ANEXOS 64 


\section{RESUMO}

O presente trabalho apresenta estudos experimentais sobre os eventos responsáveis pela mobilização leucocitária na vigência de processos inflamatórios, especialmente os voltados às interações dos leucócitos ao endotélio vascular, eventos iniciais e fundamentais na migração celular para o foco de lesão. Duas linhas trilham esta tese, a saber: os mecanismos de modulação endógena e os efeitos de substâncias tóxicas.

Dentro do primeiro enfoque, demonstramos que os glicocorticóides endógenos modulam o recrutamento de células brancas, por atuarem, pelo menos em parte, sobre os fenômenos de interação leucócito-endotélio. A deficiência hormonal acarreta aumento no número de leucócitos "rolling" e leucócitos aderidos à parede de vênulas pós-capilares in vivo. A interferência sobre a maturação leucocitária e a expressão de moléculas de adesão em leucócitos e célula endotelial são efeitos importantes no processo. Nesta mesma linha mostramos, ainda, que o efeito da inibição prolongada da síntese de óxido nítrico (NO; L-NAME, 20 mg/kg/dia/14 dias) promove ação antiinflamatória, visualizada pela diminuição do influxo de leucócitos para o foco de lesão, dependente de prejuízos na interação leucócito-endotélio e na expressão de moléculas de adesão.

$\mathrm{Na}$ segunda linha de investigações, estudamos os mecanismos envolvidos na toxicidade causada pela exposição a compostos fenólicos, derivados da metabolização do benzeno. Mostramos que a exposição à hidroquinona por período prolongado de tempo (50 mg/kg; via i.p.; 1 vez ao dia com intervalos de 2 dias a cada 5 doses; 13 ou 16 doses) afeta distintamente o recrutamento celular na vigência de resposta inata ou adquirida, por mecanismos complexos que envolvem ações na maturação, estado de ativação e função leucocitária. Apesar do fenol ser endogenamente metabolizado à hidroquinona, a exposição ao fenol, nas mesmas condições que a exposição à hidroquinona, não altera os parâmetros inflamatórios. 


\section{SUMMARY}

The present work shows experimental studies performed to clarify the mechanisms responsible for the control of leukocyte mobilization during inflammatory processes, specially to those related to leukocyte-endothelial interactions, fudamental and initial events to cellular migration into lesioned areas. Two lines of investigations lead this work, as follow: mechanisms of endogenous modulations and effects of toxic substances.

At the first line, we demonstrated that endogenous glucocorticoids modulate the white cells recruitment, by acting, at least in part, on leukocyteendothelial interactions. Deficiency of hormones induces increment on number of rolling and adhered leukocytes to postcapillary venules in vivo. Modulations on leukocyte maturation phases and on adhesion molecules expressions on leukocytes and endothelial cells are important actions in these effects. At the same line of investigations, we also showed that chronicle inhibition of NO synthesis (L-NAME, $20 \mathrm{mg} / \mathrm{Kg} /$ day, during 14 days) reduces leukocyte influx into inflammatory site, dependent on impairment on leukocyte-endothelial interactions and on adhesion molecules expressions.

The second line of investigations comprises the mechanisms responsible for the toxicity provoked by exposuring animals to phenolic compounds derived from benzene's biotransformation. We showed that hidroquinone exposure for a prolonged period of time $(50 \mathrm{mg} / \mathrm{kg}$; i.p. route; once a day, with interval of 2 days each 5 doses; 13 or 16 doses) affects the cellular recruitment during an innate or acquired inflammatory reaction, throughout complex mechanisms which involve actions on maturation, activation and functions of leuckocytes. Despite fenol be endogenously transformed to hydroquinone, fenol exposure does not promote similar effects of hidroquinone administrations. 


\section{INTRODUÇÃO}

\subsection{Mobilização leucocitária}

As associações da presença de leucócitos no tecido extravascular e a resposta a uma lesão foram inicialmente constatadas no final do século XIX por Dutrochet (1824), Addison (1843) e Waller (1846), sendo que este último também correlacionou o evento à formação de exsudato purulento. Subseqüentemente, Cohnheim (1867) descreveu que as bases fundamentais para a resposta tecidual à injúria dependiam da presença de leucócitos e da formação do exsudato inflamatório, sendo que alterações na parede microvascular favoreciam as interações celulares necessárias para o processo. Desta forma, foi descrita a primeira evidência da importância da interação leucócito-endotélio. Vinte e seis anos mais tarde, o brilhante Metchnikoff (1893) e seus discípulos postularam que o processo inflamatório era dependente da atividade de leucócitos em resposta à ação de agentes químicos extravasculares, com propriedades de induzirem a migração leucocitária. Assim, os primeiros conceitos da quimiotaxia foram inseridos (revisto em Rampart, 1994). Desde então, os mecanismos que regem as interações celulares, bem como as adesões entre as células e os componentes dos microambientes em cada etapa da migração leucocitária, são alvos de intensas investigações.

Desde o início até sua resolução, a reação inflamatória é caracterizada pela infiltração sucessiva dos diferentes subtipos de células brancas. A mobilização dos compartimentos de reserva e o recrutamento seqüencial no curso do processo - neutrófilos seguido pelas células mononucleares e eosinófilos - são eventos complexos e vitais para eficiência da imunidade inata e adaptativa. A complexidade do processo é decorrente da ação de inúmeros mediadores químicos, que desencadeiam sinalizações intracelulares diferentes para expressão de receptores e alterações morfológicas durante a ativação e locomoção leucocitárias. Interferências nestes eventos acarretam prejuízos 
sérios à instalação, desenvolvimento e resolução de processos inflamatórios de diferentes origens.

\subsubsection{Interação leucócito-endotélio}

A mobilização dos leucócitos circulantes inicia-se com a mudança na localização das células e elementos figurados na corrente sangüínea. Em condições normais de fluxo, os leucócitos circulam no centro da corrente sangüínea. As interações das células brancas e a parede vascular são inexpressivas, com exceções do "pool" periférico de leucócitos aderidos à parede dos vasos da microcirculação, principalmente pulmonar, e de linfócitos no processo de recirculação, os quais interagem com células endoteliais especializadas de tecidos linfóides secundários. A posição central dos leucócitos na corrente sangüínea é dependente, pelo menos em parte, de seu maior tamanho em relação aos demais componentes sangüíneos. Na vigência de um processo inflamatório, uma série de eventos contribui para o contato inicial das células brancas com o endotélio vascular, entre os quais: 1) as alterações na hemodinâmica microvascular, representadas pela vasodilatação, aumento de permeabilidade vascular e redução de fluxo em capilares e vênulas pós-capilares, que em conjunto provocam modificações no estado de agregação e velocidade de eritrócitos na circulação, e 2) a expressão de receptores, denominados de moléculas de adesão (Schmid-Schönbein e cols., 1980; Pearson e Lipowsky, 2000; revisto em Sun e cols., 2003).

Comportamento "rolling" foi a denominação conferida ao contato inicial dos leucócitos ao endotélio, pela habilidade destas células de deslizarem sobre a parede vascular com velocidade menor que o fluxo sangüíneo e aderirem, momentaneamente. Com a progressão do processo inflamatório, o tempo de aderência à parede vascular aumenta e os leucócitos aderem firmemente ao endotélio. Estes eventos, denominados em conjunto de interação leucócitoendotélio, são iniciais e fundamentais para a subseqüente diapedese e migração para o interstício adjacente. 
A expressão coordenada e sucessiva de moléculas de adesão nas membranas celulares durante os eventos de interação leucócito-endotélio é um paradigma que foi atribuído após um grande número de estudos experimentais, que demonstraram que o bloqueio na síntese, expressão, interação com ligante(s) específico(s) ou na sinalização intracelular induzida pela molécula prejudicava especificamente cada etapa do processo. Estes estudos descreveram a gênese de doenças, até então desconhecidas, caracterizadas pela inabilidade de resposta a infecções, e denominadas de LAD (leukocyte adherence deficiency) (revistos em Roos e Law, 2001; Bunting e cols., 2002; Wild e cols., 2002; Alon e Etzioni, 2003).

A descrição das moléculas de adesão, desde o final da década de 1980, tem contribuído efetivamente para o conhecimento das bases fisiológicas e patológicas das interações celulares em processo vitais como fertilização, embriogênese, formação e manutenção da integridade tecidual, angiogênese, defesa, cicatrização, reparo e na formação de metástases. Nos últimos anos tem sido amplamente demonstrado que o papel das moléculas de adesão vai muito além da mediação das interações celulares, uma vez que vias de sinalizações intracelulares são ativadas após a expressão e/ou ligação destas moléculas. No que concerne à resposta inflamatória, as sinalizações conferem amplificação do processo, entre outros efeitos, pela síntese/expressão de moléculas de adesão, redistribuição de receptores na membrana celular, reorganização intracelular e síntese de mediadores inflamatórios. Desta forma, estas moléculas têm sido alvo para marcadores de doenças e para intervenções farmacológicas (revistos em Kluger, 2004; Bochner, 2004; Szekanecz e Koch, 2004; Ehrhardt e cols., 2004).

Dentro da cascata de ativação das moléculas de adesão, as moléculas pertencentes à família das selectinas são fundamentais para o comportamento "rolling" de leucócitos. Três moléculas desta família foram descritas e agrupadas pela sua capacidade de ligar-se a carboidratos sialilados, fucosilados e sialomucinas, presentes constitutivamente nas membranas celulares (Taylor e Drickamer, 1993; Vestweber e Blanks, 1999). A semelhança destes carboidratos às lectinas de plantas denominou esta família de LEC-CAM (lectin-cell adhesion molecules). A deficiência de síntese de carboidratos, 
principalmente fucosilados, determina prejuízo no "rolling" de leucócitos e, conseqüentemente, na aderência ao endotélio e no influxo de células brancas para o foco de lesão. Este padrão de comportamento tem sido demonstrado em animais "knockout" para síntese de carboidratos e em indivíduos com LAD tipo II, caracterizada por deficiência de carboidratos fucosilados desencadeada por mutações gênicas em um sistema de transporte de fucose localizado no complexo de Golgi (para revisões Roos e Law, 2001; Bunting e cols., 2002). Tem sido demonstrado que a administração oral de fucose restaura a ligação celular às selectinas e corrige a neutrofilia detectada nestes pacientes. Se o tratamento é interrompido, após alguns dias, o mesmo padrão de doença reaparece (Lühn e cols., 2001).

A L-selectina (CD62L) ou Mel-14 ou lectin-like cell adhesion molecule-1 (LECAM-1) medeia o "homing" de linfócitos às células endoteliais especializadas dos linfonodos (Gallatin e cols., 1983; Butcher e Picker, 1996) e o "rolling" de leucócitos em respostas inflamatórias agudas e crônicas (Tedder e cols., 1995; Winn e cols., 1998). Uma peculiaridade da L-selectina é sua rápida clivagem da membrana após ativação celular pela ação de metaloproteinases presentes na parede celular, gerando um ectodomínio solúvel e um pequeno fragmento retido na membrana (Zhao e cols., 2001; Smalley e Ley, 2005). O mecanismo de clivagem é dependente de vias de sinalização intracelulares, que envolvem proteína quinase $C$ e inibição de calmodulina (Fors e cols., 2001; Smalley e Ley, 2005). O significado biológico da clivagem protéica tem sido demonstrado, experimentalmente, pela contínua migração de linfócitos para os linfonodos e pelo maior influxo e por tempo mais prolongado de neutrófilos para o peritôneo inflamado na vigência de bloqueio enzimático (Venturi e cols., 2003).

A P-selectin (CD62P) ou granule membrane protein 140 (GMP140) é expressa constitutivamente nos grânulos $\alpha$ de plaquetas (Stenberg e cols., 1985) e nos corpúsculos de Weibel-Palade no endotélio (Bonfanti e cols., 1989). Após ativação, a molécula é rapidamente transportada para as membranas celulares (Dunlop e cols., 1992; Michelson e cols., 1996; Hartwell e cols., 1998); no entanto, sua expressão é passageira. Em plaquetas, sofre clivagem; e no endotélio, grande parte é re-internalizada, sendo que o restante 
é clivado (Burger e Wagner, 2003). A P-selectina participa da interação responsável pelo comportamento "rolling" de leucócitos e da agregação heterotípica de plaquetas a leucócitos. Desta forma, é uma molécula importante para conexão entre inflamação, trombose e coagulação em áreas de lesão (Palabrica e cols., 1992). Sua expressão em plaquetas presentes em trombos em crescimento facilita o recrutamento dos leucócitos circulantes, além de induzir a sinalização intracelular para síntese/secreção de diferentes mediadores envolvidos no processo (revistos em Andre, 2004; Geng e cols., 2004).

A E-selectina (CD62E) ou endothelial-leukocyte adhesion molecules (ELAM-1) é expressa na célula endotelial pela ação de vários mediadores inflamatórios, entre os quais o fator de necrose tumoral $\alpha(\mathrm{TNF}-\alpha)$ e a interleucina-1 (IL-1), com pico de expressão na quarta hora e declínio 24 horas após estimulação (Bevilacqua e cols., 1987). A regulação de sua transcrição é dependente de vários fatores, i uindo o fator nuclear kappa B (NF-к B) e o ativador de proteína 1 (AP-1) (revisto em Ehrhardt e cols., 2004). Uma vez expressa, a molécula é clivada ou lentamente re-internalizada para os lisossomos, com subseqüente degradação (Subramaniam e cols., 1993). A clivagem exacerbada de E-selectina e a conseqüente elevação da concentração de sua forma solúvel no plasma desencadeia sintomatologia semelhante à observada em pacientes com LAD e, desta maneira, foi proposto que esta poderia ser um tipo de manifestação da doença (DeLisser e cols., 1999).

As integrinas compõem uma família de moléculas que medeiam a interação leucócito-endotélio e leucócito-matriz extravascular. Sua denominação foi decorrente da habilidade de integrar o meio intra e extravascular e, assim, são importantes sinalizadoras em diferentes processos fisiopatológicos (revistos em Rossetti e cols., 2002; Hogg e cols., 2002). Todas as integrinas são heterodímeros compostos de uma subunidade $\alpha$ e uma subunidade $\beta$. A perfeita associação das diferentes subunidades $\alpha$ a uma subunidade $\beta$ comum determinou a classificação destas moléculas em subfamílias. Desta forma, as integrinas são agrupadas em pelo menos 5 subfamílias (revisto em GonzálezAmaro e Sánchez-Madrid, 1999; Arnaout e cols., 2005). A subfamília $\beta_{2}$ ou 
complexo CD18 é composta de 4 moléculas, a saber: CD11a/CD18 ou lymphocyte function associated 1 (LFA-1), CD11b/CD18 ou macrophage antigen-1 (MAC-1), CD11c/CD18 ou gp150,95 e CD11d/CD18. São expressas exclusivamente em leucócitos, medeiam a aderência ao endotélio e sua subseqüente diapedese. Neste processo, os ligantes para as $\beta_{2}$ integrinas são as moléculas que compõem a família das imunoglobulinas, além da fração C3b do complemento e de proteoglicanos (revisto em González-Amaro e SánchezMadrid, 1999). A adesão celular mediada pelas $\beta_{2}$ integrinas é decorrente de expressão qualitativa, pela ativação de moléculas quiescentes nas membranas leucocitárias, ou quantitativa, proveniente de mobilização de estoques intracelulares e de síntese protéica (Chatila e cols., 1989; revisto em Gahmberg e cols., 1997). Assim, uma série de mediadores químicos e hormônios interferem na expressão das integrinas, por mecanismos transcripcionais e pós-transcripcionais ou por provocarem alterações estruturais em moléculas constitutivamente expressas (revisto em Kim e Yamada, 1997). A deficiência autossômica recessiva para a síntese da cadeia $\beta_{2}$ foi denominada LAD I e caracterizada pela inabilidade dos leucócitos aderirem ao endotélio e migrarem para o foco de lesão. Indivíduos portadores desta doença, classificada como leve, moderada ou grave de acordo com a porcentagem de expressão das $\beta_{2}$ integrina, apresentam leucocitose persistente e processos infecciosos freqüentes e graves (Crowley e cols., 1980; Arnaout e cols., 1982; Springer, 1985; Dana e Arnaout, 1988; revisto em Etzioni e cols., 1999). Recentemente, uma doença com sintomatologia semelhante à LAD I foi denominada de LAD III e sua gênese foi associada à inabilidade de ativação de $\beta_{2}$ integrinas por receptores de membranas ligados à proteína G (Alon e Etzioni, 2003).

As imunoglobulinas são membros de uma família de moléculas de adesão, compostas por um domínio extracelular constituído de várias unidades repetidas e homólogas a domínios de imunoglobulina $G$, uma região transmembrana e uma pequena cauda citoplasmática. São expressas em diferentes tipos celulares, mas como citado acima, são as ligantes no endotélio para as $\beta_{2}$ integrinas nos processos de aderência e diapedese. As expressões da intercellular cell adhesion molecule-1 (ICAM-1) e vascular cell adhesion molecule-1 (VCAM-1) no endotélio quiescente são baixas, mas na presença 
de estímulos inflamatórios suas concentrações na membrana endotelial são extremamente aumentadas. Diferentemente, as expressões constitutivas da intercellular cell adhesion molecule-2 (ICAM-2) e platelet endothelial cell adhesion molecule-1 (PECAM-1) são significativas (revisto em Huo e Ley, 2001). Neste contexto, vale ressaltar que a localização constitutiva e predominante de PECAM-1 nas junções interendoteliais é fundamental para a manutenção fisiológica da junção interendotelial e para diapedese de leucócitos na vigência de processo inflamatório (revisto em Muller e Randolph, 1999; Luscinskas e cols., 2002).

Apesar da comprovada expressão seqüencial das moléculas de adesão citadas acima em processos inflamatórios de diferentes origens, vias alternativas têm sido propostas e parecem ser dependentes de características específicas dos leitos microcirculatórios dos tecidos lesados (Duncan e cols., 1999; Doerschuk e cols., 2000; Doerschuk, 2001). Recentemente, tem sido demonstrado que uma classe de enzimas, semelhantes às monoaminoxidases, chamadas vascular adhesion protein -1 (VAP-1), medeia o "rolling" e a aderência de leucócitos em alguns modelos de inflamação e na recirculação de linfócitos. Apesar do mecanismo ainda não estar estabelecido, há evidência de uma ação própria, como moléculas de adesão, mediando diretamente o "rolling", ou pela expressão de P-selectina induzida pela ação do peróxido de hidrogênio gerado em decorrência de sua atividade enzimática na deaminação de aminas primárias (Salmi e Jalkanen, 2001). Sua participação na migração leucocitária tem sido amplamente demonstrada in vivo e in vitro em modelos de inflamação aguda e crônica e na rejeição de transplantes (Yegutkin e cols., 2004; Koskinen e cols., 2004; Martelius e cols., 2004; Merinen e cols., 2005; Stolen e cols., 2005).

Uma das características presente nas LAD é a leucocitose persistente. Este efeito é resultante da manutenção das células na circulação e da hematopoese alterada. A participação efetiva das selectinas e integrinas na manutenção celular durante as etapas de produção e diferenciação das células brancas na medula tem sido demonstrada, como revisto por Chan e Watt (2001). Na população mielóide, a expressão de L-selectina varia de acordo com suas etapas de maturação e sua clivagem é fundamental para mobilização 
dos leucócitos para a circulação (van Eeden e cols., 1997; Dimitroff e cols., 2001; Carion e cols., 2002). Adicionalmente, a interação das selectinas com seus ligantes específicos induz sinalização para modificação da expressão, estado de ativação e função de integrinas envolvidas na hematopoese (revisto em Gonzalez-Amaro e Sanchez-Madrid, 1999). Neste contexto, é importante ressaltar o papel relevante das $\beta_{2}$ integrinas e imunoglobulinas na sinalização de síntese de citocinas, fatores de crescimento e outras moléculas de adesão durante a hematopoese (revisto em Verfaillie, 1998; Chan e Watt, 2001).

Do exposto fica evidente que as moléculas de adesão modulam a interação leucócito-endotélio e atuam como sinalizadores intracelulares em diferentes microambientes durante a mobilização leucocitária em condições fisiológicas e na gênese de diferentes doenças, entre as quais, as de origem inflamatória.

Nossos trabalhos investigam o controle endógeno da migração leucocitária durante respostas inflamatórias e os efeitos de xenobióticos sobre este processo. Desta forma, a expressão/ativação das moléculas de adesão são eventos abordados neste estudo.

\subsection{Controle endógeno da mobilização leucocitária}

\subsubsection{Glicocorticóides endógenos}

Os glicocorticóides (GC) são agentes antiinflamatórios e imunossupressores potentes utilizados amplamente na clínica médica. No entanto, seus efeitos adversos intensos e graves podem restringir suas aplicações, apesar do grande benefício terapêutico.

O uso terapêutico dos GC se iniciou na década de 1950 a partir de estudos que mostraram a importância dos hormônios secretados pelas glândulas adrenais na homeostasia. A partir destes trabalhos, foi demonstrada a ativação do eixo hipotálamo-hipófise-adrenal na vigência de estresse de diferentes origens. No que concerne à resposta inflamatória, é conhecido que mediadores inflamatórios secretados localmente no processo, entre os quais 
IL-1, interleucina-2 (IL-2), interleucina-6 (IL-6), interferon- $\gamma$ (INF- $\gamma$ ) e fator de necrose tumoral (TNF $\alpha$ ), alcançam a circulação sangüínea e estimulam centros específicos no hipotálamo e na hipófise que induzem, respectivamente, a secreção do hormônio liberador de corticotrofina $(\mathrm{CRH})$ e do hormônio adrenocorticotrófico (ACTH). As células do córtex adrenal, estimuladas pelo $\mathrm{ACTH}$, secretam GC que atuam como moduladores endógenos do processo (Leme e Schapoval, 1975; revistos em Tilders e cols., 1994; Haddad e cols., 2002). Ainda, alguns mediadores podem estimular as células adrenais diretamente, provocando a secreção hormonal (revisto em Haddad e cols., 2002).

A maioria dos efeitos antiinflamatórios dos GC é desencadeada por ação genômica, que leva a uma regulação positiva ou negativa da síntese de proteínas participativas do processo. O mecanismo molecular de ação inicia-se com a interação dos esteróides com o receptor protéico citosólico, composto por uma proteína da família das heat shock protein (HSP 90), um membro da família das heat shock family of stress induced protein (HSP70) e uma imunofilina, integrante da família de proteínas que se liga a agentes imunossupressores. Esta conformação protéica parece ser necessária para a manutenção do estado inativo do receptor na ausência do agonista. Duas isoformas do receptor têm sido descritas. $\mathrm{A}$ isoforma $\alpha$, que liga-se ao hormônio e ativa os genes responsivos aos GC, entre os quais os responsáveis pelos efeitos antiinflamatórios; e a isoforma $\beta$, que não se liga ao hormônio, mas liga-se ao DNA, e parece atuar como regulador negativo da ativação mediada pela isoforma $\alpha$. Expressões deste tipo de receptor estão associadas aos casos de resistência a GC durante resposta inflamatória (revisto em Smoak e Cidlowski, 2004; Lu e Cidlowski, 2004; Rhen e Cidlowski, 2005). Após interação hormonal, o receptor $\alpha$ dissocia-se das proteínas adjacentes, sofre fosforilações que resultam na homodimerização do complexo receptor-agonista e na sua transmigração para o núcleo. Nesta localização, o complexo hormônio-receptor pode atuar das seguintes maneiras: 1) domínios da região $\mathrm{N}$-terminal do receptor ligam-se a seqüências específicas do DNA (glucocorticoid responsive element, GRE), positivas ou negativas, nas regiões promotoras dos genes, com conseqüente iniciação ou repressão da 
transcrição; 2) pela estabilização da estrutura do DNA, evitando a ligação de fatores de transcrição (revisto em Barnes, 1998); 3) pela indução de RNAases específicas, que diminuem a estabilidade das respectivas RNAm (Fessler e cols., 1996); 4) ou pela ligação com fatores de transcrição, como o AP-1 e o NF-kB, inativando-os (McEwan e cols., 1997; Wissink e cols., 1998; Reichardt e Schutz, 1998; revisto em Goulding, 2004; Rhen e Cidlowski, 2005).

Adicionalmente, um outro mecanismo, conhecido como não genômico, tem sido proposto e parece estar relacionado a doses elevadas dos hormônios. Os efeitos são rápidos (segundos e minutos após terapia hormonal) e não são abolidos pela ação de inibidores da transcrição gênica e de síntese protéica. $O$ mecanismo molecular ainda não é conhecido, mas há evidências da participação de um receptor de superfície (Hafezi-Moghadam e cols., 2002; Bartholome e cols., 2004) ou da simples interação dos GC com os fosfolípedes de membrana. Este último mecanismo poderia alterar as propriedades físicas e químicas de proteínas e receptores constitutivos na membrana (revisto em Goulding, 2004; Stellato, 2004). Neste último contexto, tem sido demonstrado que a capacidade metabólica de células imunes ativadas por citocinas é rapidamente reduzida após a administração de GC. As células apresentaram decréscimo no consumo de ATP e de substratos para reações de oxidação (Schmid e cols., 2000). A importância deste mecanismo não está bem estabelecida para os diversos efeitos dos GC, mas parece ter papel significativo em diferentes condições fisiopatológicas e terapêuticas, principalmente na artrite reumatóide após pulso-terapia (Hafezi-Moghadam e cols., 2002; revisto em Pitzalis e cols., 2002; Smoak e Cidlowski, 2004; Goulding, 2004; Rhen e Cidlowski, 2005).

Dentre os inúmeros efeitos antiinflamatórios, os GC secretados ou exógenos são moduladores importantes do recrutamento leucocitário para o foco de lesão, por interferirem diretamente sobre as propriedades de adesão e/ou locomoção celular ou por inibirem a secreção de mediadores inflamatórios envolvidos no processo (Flower e cols., 1986; Moraes e cols., 1987; Perretti e cols., 1989; Stenberg e cols., 1990; revistos em Morand e Leech, 2001; Pipitone e cols., 2001). 
Nós demonstramos que os GC endógenos inibem a migração leucocitária por modularem as etapas iniciais da interação leucócito-endotélio. Ratos Wistar, machos, submetidos à adrenalectomia bilateral ou tratados com metopirona, inibidor da síntese de GC, apresentavam valores maiores de leucócitos "rollers" em vênulas pós-capilares da fáscia espermática interna in vivo que animais controles submetidos à falsa-cirurgia ou não manipulados. Modulação adicional do hormônio sobre o processo de aderência pôde ser inferida, já que o número de células aderidas à parede vascular na pós indução de resposta inflamatória local também foi maior em animais com deficiência hormonal e, ainda, a administração de anticorpo monoclonal anti $\beta 2$ integrina reverteu o efeito. $O$ envolvimento do mecanismo genômico nestas modulações foi demonstrado pela similaridade dos quadros detectados em animais com deficiência hormonal e animais normais pré-tratados com RU 38486, antagonista de receptor citosólico de glicocorticóides, actinomicina D, inibidor da transcrição gênica, e cicloheximida, inibidor da síntese de proteínas (FARSKY, S.H.P.; SANNOMIYA, P.; GARCIA-LEME, J. Secreted glucocorticoids regulate leukocyte-endothelial interactions in inflammation: A direct vital microscopic study. Journal of Leukocyte Biology, 57:379-86, 1995).

Com a descrição do envolvimento primordial das moléculas de adesão na interação leucócito-endotélio, o papel dos CG sobre a expressão/atividade das mesmas começou a ser investigado. Reduções ou não alterações nas sínteses e/ou expressões destas moléculas in vivo foram observadas em condições de concentrações elevadas dos hormônios, determinadas por administrações de doses farmacológicas dos mesmos ou por diferentes estados de estresse (Leech e cols.,1998; Fassbender e cols., 1999; Torsteinsdottir e cols., 1999; Mori e cols., 2000; Kaname e cols., 2002; Weber e cols., 2001; 2004; Sale e cols., 2004).

Entretanto, a ausência de efeitos ou a inibição da expressão das moléculas parece não ser válida em todos os casos. Recentemente, um estudo com pacientes em choque séptico tratados com baixas doses de hidrocortisona quantificou as concentrações séricas de moléculas de adesão solúveis como 
determinantes da ativação endotelial. O tratamento reduziu a concentração de E-selectina, aumentou signifićantemente a concentração de ICAM-1 e não alterou as elevadas concentrações de P-selectina e VCAM-1, indicando que, em baixas concentrações terapêuticas, os glicocorticóides controlam diferentemente a expressão de moléculas de adesão no endotélio e a presença de suas formas solúveis na circulação (Leone e cols., 2004). Estes efeitos discrepantes podem ser atribuídos às diferentes condições de ativação celular e às doses dos $G C$, uma vez que a eficácia do $G C$ depende da sua ligação ao receptor. Mudanças na densidade, afinidade e atividade do receptor ocorrem em diferentes concentrações hormonais desencadeadas por doenças ou protocolos terapêuticos (Schaaf e Cidlowski, 2003).

Como já havíamos demonstrado que os GC endógenos poderiam modular a aderência por controlar a expressão/atividade das $\beta 2$ integrinas, passamos a utilizar nossos modelos animais para investigar os efeitos da secreção de GC sobre as demais moléculas de adesão responsáveis pela interação leucócito-endotélio.

Mostramos que um dos mecanismos dos $\mathrm{GC}$ endógenos envolvidos no recrutamento leucocitário é a modulação da expressão de L-selectina em leucócitos polimorfonucleares (PMN). A expressão da molécula em PMN obtidos da medula óssea de ratos adrenalectomizados foi significativamente menor que em células obtidas de ratos falso-operados ou não-manipulados, usados como controles. Este efeito pode ser um dos responsáveis pela aceleração na maturação destas células e pela conseqüente neutrofilia detectada em animais com deficiência hormonal. Inversamente, a expressão de L-selectina em PMN circulantes de animais adrenalectomizados estava aumentada, e esta alteração pode ser um dos determinantes para o aumento do número de leucócitos em comportamento "rolling" e pela maior migração para o foco de lesão por nós previamente demonstrados. Os efeitos moduladores sobre a expressão de L-selectina não foram decorrentes de modificações na expressão gênica, uma vez que ensaios de reverse transcription-polymerase chain reaction (RT-PCR) mostraram valores equivalentes de RNAm em leucócitos segmentados da medula óssea e 
neutrófilos circulantes de animais adrenalectomizados e não-manipulados. Estes dados sugeriram que os GC endógenos modulam a clivagem da Lselectina. Cabe ressaltar que a modulação dos GC endógenos sobre as moléculas de adesão em PMN durante a interação leucócito-endotélio parece ser restrita à expressão de L-selectina, uma vez que a expressão de $\beta_{2}$ integrina em neutrófilos não foi alterada pela adrenalectomia e neutrófilos circulantes de animais adrenalectomizados possuem menor habilidade de aderirem à célula endotelial in vitro (CAVALCANTI, D.M.H.; LOTUFO, C.M.C.; BORELLI, P.; MARKUS, R.P.; FARSKY, S.H.P. Adrenal deficiency alters mechanisms of neutrophil mobilization. Molecular and Cellular Endocrinology, 2006).

No entanto, o controle sobre a aderência parece estar associado ao efeito dos GC sobre o endotélio. A habilidade da célula endotelial de animal adrenalectomizado aderir neutrófilos foi marcantemente maior que o endotélio de animais controles, falso-operados e não-manipulados. Esta maior habilidade foi reforçada pelas maiores expressões de ICAM-1, VACM-1 e PECAM-1 em células endoteliais da microcirculação do músculo cremaster de animais adrenalectomizados. Ainda, corroborando o controle preferencial sobre os PMN durante o comportamento "rolling", a expressão de P-selectina não foi modificada pela deficiência hormonal (CAVALCANTI, D.M.H.; LOTUFO, C.M.C.; MAIA, A.; CHUDZINSKI-TAVASSI, A.M.; MARKUS, R.P.; FARSKY, S.H.P. Endogenous control of glucocorticoids on endothelial adherence. Em preparação).

A modulação endógena dos glicocorticóides sobre a clivagem de Lselectina foi surpreendente, já que a maioria dos trabalhos sugere que a administração exógena dos hormônios promove inibição de sua síntese, especificamente por células circulantes (Weber e cols., 2001; 2004). Como já salientado anteriormente, a clivagem de L-selectina é dependente da ação de metaloproteinases de membranas (Zhao e cols., 2001; Smalley e Ley, 2005), dependente de vias de sinalização intracelulares, que envolvem proteína quinase C e a inibição de calmodulina (Fors e cols., 2001; Smalley e Ley, 
2005). Assim, os efeitos dos glicocorticóides endógenos sobre as enzimas e as vias de sinalização citadas acima serão objetos de investigações futuras.

O envolvimento do mecanismo genômico nas ações dos GC sobre os eventos inflamatórios pelo bloqueio do seu receptor citosólico tem sido amplamente demonstrado. A estratégia mais utilizada é a administração do antagonista de receptor RU 38 486, comercialmente denominado de mifepristone (revisto em Pitzalis e cols., 2002). No que concerne às moléculas de adesão, tem sido amplamente demonstrado que os GC exógenos regulam a expressão gênica de diferentes moléculas de adesão pela interação com seu receptor citósólico $(\alpha)$ e subseqüente interação com GRE no DNA, inibindo suas sínteses, ou por interferirem com ativação de fatores de transcrição, entre os quais o AP-1 e o NFKB (revisto em Pitzalis e cols., 2002; Almawi e cols., 2002; Hayashi e cols., 2004; Caramori e Adcock, 2005).

Como tínhamos evidências da participação do receptor citosólico no controle da interação leucócito-endotélio in vivo (Farsky e cols., 1995), neste momento estamos investigando a importância deste receptor nos efeitos por nós detectados. Para tanto, estão sendo utilizados animais tratados com o RU 38486 , sendo que os dados obtidos até o momento mostram que a neutrofilia e os efeitos sobre as moléculas de adesão (a clivagem da L-selectina e a superexpressão de ICAM-1, VCAM-1 e PECAM-1) são mediados pela interação dos hormônios ao receptor citosólico. Paralelamente, estamos avaliando se efeitos são decorrentes de modificaçãoes na sinalização mediada por AP-1 ou NFkB. Verificamos que a translocação de NFKB está reduzida em neutrófilos e aumentada na célula endotelial de animais adrenalectomizados em comparação aos mesmos tipos celulares de animais controles. Embora preliminares, estes dados sugerem diferentes vias de mediação intracelular nos efeitos dos GC endógenos em PMN e na célula endotelial.

\subsection{2 Óxido Nítrico}

O óxido nítrico (NO) é uma molécula importante na sinalização intra e intercelular em diferentes processos fisiológicos e patológicos. O NO regula o 
tônus vascular, está relacionado à reatividade plaquetária, age como neurotransmissor e apresenta atividade citotóxica, particularmente em processos inflamatórios (Moncada e Higgs, 1991; Alderton e cols., 2001; Bogdan, 2001; Dawn e Bolli, 2002).

O NO é um radical livre de meia-vida muito curta. É sintetizado a partir da L-arginina e do oxigênio molecular, utilizando a nicotinamida adenina dinucleotídeo fosfato (NADPH) como doador de elétrons e grupamento heme, flavina mononucleotídeo (FMN), flavina adenina dinucleotídeo (FMD) e tetrahidrobiopterina $(\mathrm{BH} 4)$ como cofatores da reação. A produção de NO é catalisada por um grupo de enzimas homodiméricas (130-160 kDa) denominadas óxido nítrico sintases (NOS) (revsito em Aktan, 2004). Na presença de oxigênio, o $\mathrm{NO}$ é rapidamente metabolizado em nitrito $\left(\mathrm{NO}_{2}{ }^{-}\right)$e nitrato $\left(\mathrm{NO}_{3}{ }^{-}\right)$(Mayer e cols., 1998).

Três isoformas distintas de $\quad S$ foram identificadas. Duas isoformas constitutivas (cNOS), com atividade regulada por cálcio e calmodulina, a saber: 1) NOS neuronal (nNOS) ou NOS I, descrita inicialmente no sistema nervoso central e periférico, e 2) NOS endotelial (eNOS) ou NOS III, presente nas células do endotélio vascular. Uma terceira isoforma denominada NOS induzível (iNOS) ou NOS II, cuja expressão é independente de cálcio, pode ser isolada de uma enorme variedade de células, após ação de mediadores inflamatórios e produtos bacterianos (revistos em Laroux e cols., 2000; Hickey e cols., 2001). As NOS variam quanto suas expressões e distribuições celulares e teciduais (revisto em Stuehr, 1999).

Inibidores e/ou doadores de NO são ferramentas amplamente empregadas em estudos experimentais que investigam a influência do mediador em diferentes processos fisiopatológicos, entre os quais, a resposta inflamatória. $\mathrm{N}^{\mathrm{G}}$-nitro-L-arginina metil éster (L-NAME) é um análogo da Larginina que inibe de maneira competitiva e não específica as NOS (Moore e cols., 1990). Há evidências que os tempos de tratamentos e as dosagens de inibidores/doadores contribuem para as diferentes respostas nos incontáveis estudos experimentais, principalmente quanto ao efeito pressórico e no processo inflamatório (Navarro-Cid e cols., 1996; Forster e cols., 2001; Dedeoglu e cols., 2001; Quiroz e cols., 2001). Abordagens mais atuais, que 
envolvem o emprego de agentes sintéticos capazes de inibirem especificamente cada uma das três formas enzimáticas e a utilização de animais geneticamente deficientes das NOS, têm fornecido dados complementares e mais sensíveis aos obtidos com os inibidores não seletivos e, ainda, corroboram uma complexa relação entre efeitos pró e antiinflamatórios e as diferentes atividades enzimáticas (Hickey e cols., 1997; Hobbs e cols, 1999; lalenti e cols., 2000; Sanz e cols., 2001; Louin e cols., 2006; Jiménez-Altayó, 2006).

As ações pró-inflamatórias do NO estão relacionadas, possivelmente, à sua habilidade de aumentar a permeabilidade vascular e o edema por meio do incremento do fluxo sangüíneo local (revsitos em Colasanti e Suzuki, 2000; Canty, 2000) e ao seu alto potencial lesivo, pela habilidade de interagir com espécies reativas de oxigênio (ERO), como ânion superóxido $\left(\mathrm{O}_{2}^{-}\right)$, levando à formação de peroxinitrito (ONOO-). Este último mecanismo ocorre, predominantemente, em concentrações elevadas de NO proveniente da iNOS, e os produtos formados alteram a estrutura de proteínas por reagirem com biomoléculas, como tióis e aminas presentes em peptídeos e proteínas, resultando na formação de S-nitrosotióis (revsitos em Bogdan, 2001).

As ações antiinflamatórias estão relacionadas à modulação da migração leucocitária, controlando as interações dos leucócitos circulantes ao endotélio vascular (Kubes e cols., 1991; Arndt e cols., 1993; Granger e Kubes, 1994). No entanto, os dados são controversos e não estão completamente elucidados.

Especificamente na artrite humana ou experimental, tem se demonstrado que o NO possui papel pró-inflamatório, uma vez que animais tratados com L-NAME apresentaram valores de células brancas nas cavidades articulares menores que os encontrados em animais controles (McCartneyFrancis e cols., 1993; Stefanovic- Racic e cols., 1994; Mello e cols., 1997; Palácios e cols., 1999). O papel pró-inflamatório do NO foi confirmado pela maior produção de $\mathrm{NO}_{2}^{-} / \mathrm{NO}_{3}{ }^{-}$no líquido sinovial de pacientes com artrite reumatóide quando comparados a pacientes portadores de doenças como osteoatrose (Novaes e cols., 1997) e pelo aumento de expressão de iNOS, principalmente nas células mononucleares desse infiltrado (Borderie e cols., 1999). 
Os efeitos pró-inflamatórios do NO foram por nós corroborados no modelo de inflamação intraarticular induzida pelo veneno de serpentes Bothrops jararaca (VBj) em coelhos New Zeland, adultos. Animais tratados com L-NAME por período prolongado de tempo (14 dias, $20 \mathrm{mg} / \mathrm{kg}$, via oral) ou agudamente (30 mg/Kg, i.v., $30 \mathrm{~min}$ antes da injeção do VBj) apresentaram redução no extravasamento protéico e no recrutamento leucocitário para a cavidade articular 4 horas após a injeção do veneno em comparação com animais tratados com D-NAME, enantiômero inativo do L-NAME, ou com salina. As diminuições nos parâmetros inflamatórios foram acompanhadas pela redução parcial na concentração de $\mathrm{NO}_{2}{ }^{-} / \mathrm{NO}_{3}$, metabólitos estáveis do $\mathrm{NO}$, no fluído sinovial. Cabe ressaltar que o tratamento dos animais com D-arg-[Hyp ${ }^{3}$, Thi $^{5}$, Dtic ${ }^{5}$, Oic $^{8}$ ]-bradykinin (HOE 140), antagonista de receptor B2 de bradicinina (0,3 mg/kg; 30 min antes da administração do VBj), provocou o mesmo efef antiinflamatório do L-NAME e redução na concentração dos metabólitos do NO no líquido sinovial. Em conjunto, os resultados sugeriram papel pró-inflamatório e interrelação da bradicinina e NO nos efeitos próinflamatórios na artrite induzida pelo veneno de serpentes Bothrops jararaca (GUZZO, M.L.; FARSKY, S.H.P.; DE NUCCI, G.; ANTUNES, E.; SILVA, M.A.G. VERÍSSIMO DE MELLO, S.B. Role of kinins and nitric oxide on the rabbit arthrits induced by Bothrops jararaca venom. Toxicon, 38(11):15351546, 2000). Posteriormente, o papel do receptor B2 de bradicinina e sua relação com a produção de NO na indução da artrite foram ratificados, sendo a relação positiva entre $\mathrm{NO}$ e prostaglandina $\mathrm{E}_{2}\left(\mathrm{PGE}_{2}\right)$ demonstrada pela redução da concentração deste eicosanóide no líquido sinovial dos animais tratados com L-NAME ou HOE-140 (VERÍSSIMO DE MELLO, S.B.; GUZZO, M.L.; LISBOA, L.F.S.; FARSKY, S.H.P. Pharmacological characterization of arthritis induced by Bothrops jararaca venom in rabbits. A positive crosstalk between bradykinin, nitric oxide and prostaglandin E2 (BjV). Mediators of Inflammation 11 (1):13-6, 2002).

Os primeiros trabalhos relacionados aos efeitos do NO sobre a interação leucócito-endotélio mostraram que a superfusão do mesentério de gatos ou de ratos com doadores de NO acarretava diminuição nos fenômenos de "rolling" e 
aderência e, que por outro lado, a superfusão com inibidores inespecíficos das NOS promovia aumento nos eventos de interação leucocitária. Este último efeito era revertido pela suplementação de L-arginina após a superfusão com L-NAME. Em conjunto, estes dados demonstravam que o NO produzido em condições basais atuava como modulador da interação leucócito-endotélio e, conseqüentemente, permitiam inferir o $\mathrm{NO}$ constitutivo como um modulador endógeno da migração leucocitária (Kubes e cols., 1991; Arndt e cols., 1993; Granger e Kubes, 1994). Os possíveis mecanismos estavam relacionados à inibição ou ao consumo de substâncias reativas de oxigênio, entre as quais o superóxido, com conseqüente diminuição na ativação de mastócitos (Kubes e cols., 1993; Gaboury e cols., 1993). Da mesma forma que o NO constitutivo, uma linha de evidências na literatura mostra que concentrações elevadas de NO, gerado a partir da ativação da iNOS em condições inflamatórias, inibem o recrutamento leucocitário para o foco de lesão. Um dos mecanismos envolvidos parece ser também a modulação sobre a interação leucócitoendotélio, já que ensaios em animais deficientes de iNOS ou tratados agudamente com inibidores específicos da iNOS mostraram valores aumentados de leucócitos "rollers" ou aderidos em relação aos animais controles (revisto em Hickey e cols., 2001; Secco e cols., 2003).

As demonstrações do papel do NO sobre a interação leucócito-endotélio geraram a investigação imediata do papel deste mediador sobre a expressão de moléculas de adesão envolvidas neste processo. Apesar das indicações do NO inibir a síntese/expressão destas moléculas, a análise dos dados da literatura mostra a discordância de resultados. A administração de anticorpos monoclonais antimoléculas de adesão em animais tratados agudamente com LNAME e a determinação de suas expressões em células pré-incubadas in vitro com inibidores da eNOS ou com doadores de NO indicaram a habilidade do mediador obtido da NOS constitutiva modular a expressão de $\beta_{2}$ integrinas (Kubes e cols., 1991; 1994; Mitchell e cols., 1998), ICAM-1 (Niu e cols., 1994), VCAM-1 e P-selectina (Lefer e cols, 1999; Zampolli e cols., 2000). No entanto, os dados obtidos em animais deficientes de eNOS nem sempre confirmaram as observações descritas acima. Recentemente foi demonstrado que células endoteliais de camundongos geneticamente deficientes de eNOS não 
apresentaram diferenças na aderência de leucócitos e na expressão de moléculas de adesão em relação à célula de animais selvagens. Ainda, após estimulação com citocinas, a expressão de moléculas de adesão e aderência de leucócitos foi equivalente nos dois tipos celulares, indicando que a deficiência de NO constitutivo não afetava a capacidade de adesão e nem suprimia de maneira autócrina a capacidade de ativação endotelial (Kuhlencordt e cols., 2004).

Visto a discrepância de resultados quanto aos efeitos do NO sobre os fenômenos que regem a interação leucócito-endotélio, e os resultados por nós obtidos anteriormente, passamos a investigar os mecanismos envolvidos no efeito facilitador do NO sobre o influxo leucocitário. O modelo animal passou a ser o rato Wistar, macho, adulto, tratado com L-NAME, com seu enantiômero inativo (D-NAME) ou com salina estéril (14 dias, $20 \mathrm{mg} / \mathrm{kg}$, via oral). Da mesma forma que observado em coelhos, a migração leucocitária e o aumento de permeabilidade vascular no tecido subcutâneo dorsal inflamado (modelo da bolsa de ar 6 horas após injeção do VBj) estavam reduzidos nos animais tratados com L-NAME quando comparados aos animais controles (tratados com D-NAME ou salina). A eficácia do tratamento foi demonstrada pela redução parcial da concentração de $\mathrm{NO}_{2}{ }^{-} / \mathrm{NO}_{3}{ }^{-}$no exsudato inflamatório. Estudos de microscopia intravital mostraram reduções significativas no número de leucócitos "rollers" e de leucócitos aderidos ao endotélio em vênulas póscapilares da fáscia espermática interna, tanto em condições basais, como na vigência de estimulação com o VBj. A mensuração do fluxo sangüíneo de arteríolas e vênulas pós-capilares e da reatividade vascular frente à noradrenalina, acetilcolina ou histamina mostrou que os efeitos não eram decorrentes de modificações na hemodinâmica microvascular. A quantificação do número de mastócitos adjacentes às vênulas pós-capilares e sua capacidade de desgranulação frente ao composto 48/80 também descartou o possível papel do NO sobre estas células. No entanto, o número de leucócitos PMN circulantes estava significantemente aumentado em animais tratados com L-NAME, mas a quantificação dos números de leucócitos na medula óssea mostrou que a neutrofilia não era proveniente de alterações na produção e/ou 
maturação destas células. Estes dados indicavam que a neutrofilia presente em animais tratados com L-NAME poderia ser decorrente da inabilidade de neutrófilos interagirem com a parede vascular, com sua conseqüente manutenção na circulação. Os resultados subseqüentes, que mostraram redução na expressão de L-selectina em PMN circulantes de animais tratados com L-NAME, reforçaram esta hipótese. É importante salientar que esta mesma redução foi observada em leucócitos segmentados na última etapa de maturação na medula óssea sob estimulação com $\mathrm{VBj}$, indicando que a ausência de NO por período de tempo prolongado altera as propriedades adesivas de PMN, facilitando seu recrutamento para circulação e sua manutenção no compartimento periférico. Entretanto, o efeito parece ser restrito à L-selectina, uma vez que a expressão de $\beta 2$ integrina não foi alterada em células de ambos os compartimentos (FARSKY, S.H.P.; BORELLI, P.; FOCK, R.A.; PROTO, S.Z.; FERREIRA, J.M.C.; MELLO, S.B.V. Chronic blockage of nitric oxide biosynthesis in rats: effect on leukocyte endothelial interaction and on leukocyte recruitment. Inflammation Research, 53:442-542, 2004).

Os dados dos estudos da interação leucocitária foram opostos aos encontrados na literatura. No entanto, estes foram obtidos em condições de inibição das NOS por período prolongado de tempo, protocolo de inibição enzimática até então não utilizado para este tipo de estudo. Propusemos que no protocolo experimental por nós empregado ocorrem alterações em leucócitos ainda na medula óssea e, portanto, a discrepância entre nossos dados e os da literatura, provém, possivelmente, de mecanismos de ação distintos entre os diferentes protocolos de inibição das NOS. Dados obtidos recentemente em nosso laboratório mostraram que a inibição de migração leucocitária por nós detectada na vigência de inibição da síntese de NO é dependente também da menor expressão de PECAM-1, já que animais tratados com L-NAME apresentaram valores significativamente menores da expressão da molécula no endotélio que animais controles (Hebeda e cols., 2005). 
Ultimamante, tem-se verificado papel importante da nNOS na regulação da migração leucocitária, principalmente em condições de inibição da eNOS (Beck e cols., 2004). Neste contexto, camundongos deficientes de eNOS, nos quais a interação dos leucócitos circulantes ao endotélio de vênulas póscapilares do músculo cremaster não foi diferente dos animais controles, quando tratados com inibidor seletivo da nNOS, apresentaram um aumento significativo no número de leucócitos aderidos à parede vascular, sugerindo que a nNOS seja responsável pela modulação da adesão de leucócitos na ausência de eNOS (Sanz e cols., 2001). Ainda, Beck e cols. (2004) demonstraram que, em modelo de colite em camundongos, a inflamação e a mortalidade em camundongos deficientes de nNOS foi maior se comparadas com as obtidas em animais controles. Por outro lado, em animais deficientes de eNOS ou de iNOS o processo inflamatório foi menos significativo que em animais controles. Desta forma, sugeriu-se que o NO proveniente da nNOS parece exercer efeito protetor sobre o desenvolvimento do processo inflamatório, enquanto o NO proveniente da iNOS ou eNOS parece exercer efeito facilitador do processo.

Em conjunto, os dados da literatura sugerem que NO proveniente das diferentes NOS está envolvido no controle da interação leucócito-endotélio e conseqüentemente, no recrutamento leucocitário. No entanto, a participação efetiva de cada enzima no processo, especialmente em condições de inibição específica de uma delas, não está determinada.

Como L-NAME é um inibidor inespecífico das NOS e nossos resultados mostram que o tratamento não abole a produção de NO (reduções de 50\% no sangue e nos exsudatos inflamatórios), a continuidade destes estudos envolve avaliar o potencial do protocolo de tratamento com L-NAME de inibir cada uma das enzimas e correlacionar a fonte do NO remanescente em nossos ensaios. Para tanto, ensaios de RT-PCR estão sendo realizados em leucócitos e célula endotelial para se aquilatar a expressão de iNOS, eNOS e nNOS. 


\subsection{Efeitos de xenobióticos sobre a mobilização leucocitária}

\subsubsection{Compostos fenólicos derivados do metabolismo do benzeno}

As intoxicações por solventes orgânicos, entre os quais o benzeno, afetam vários sistemas endógenos por diferentes mecanismos e intensidades. De maneira geral, os efeitos se manifestam por alterações no sistema nervoso central, comprometimento hepático e renal, doenças respiratórias, doenças do tecido conjuntivo, alterações marcadas na hematopoese e no sistema imune, com a conseqüente gênese de anemias e leucemias, além de neoplasias de diferentes origens (revisto em Schenker e Jacobs, 1996; Gralewics, 1999; Garabrant e Dumas, 2000; Nietert e Silver 2000; Waidynatha e cols., 2004).

O benzeno é derivado do petróleo e empregado em diferentes ramificações industriais, principalmente como solvente para tintas, colas, vernizes, materiais de limpeza e na indústria do couro. Pelos seus graves efeitos prejudiciais à saúde, o uso do benzeno passou a ser controlado na última década e sua utilização ficou restrita às indústrias que o produzem ou utilizam-no em processos de síntese química, na composição de combustíveis e derivados do petróleo, ou em análises laboratoriais; neste último caso, somente quando não for possível sua substituição (BRASIL, 2001).

Dentre as intoxicações pelo benzeno, as mais comuns são as ocupacionais. No entanto, não são irrelevantes os casos de acidentes domésticos e de contaminação ambiental, devido à sua volatilidade. Neste último caso, vale ressaltar que o benzeno é um contaminante comum do meio ambiente, comumente gerado pelo processamento, combustão e evaporação de petróleo, além de ser um componente da fumaça do cigarro (Rothman e cols., 1996; Muzyka e cols., 1998; Javelaud e cols., 1998; Bogadi-Sare e cols., 2000; Boscolo e cols., 2000; revisto em Nietert e Silver, 2000).

Uma vez absorvido, principalmente pelas vias aérea e dérmica, o benzeno é metabolizado extensivamente pelo fígado. O passo inicial da biotransformação do benzeno é a oxidação do benzeno a epóxido (óxido de benzeno) pela ação da enzima CYP2E1 (Chepiga e cols., 1991; revisto em Snyder, 2004). O óxido de benzeno é subseqüentemente metabolizado por três 
vias, a saber: 1) conjugação com a glutationa, formando o ácido pré mercaptúrico, que posteriormente é convertido a ácido fenil mercaptúrico; 2) rearranjo não enzimático, com formação de fenol (FE), e 3) metabolização pela epóxido hidrolase, gerando os metabólitos FE, catecol (CAT), hidroquinona (HQ) e 1,2,4, benzenotriol hidroxilados (Seaton e cols., 1994). Estes compostos fenólicos são detoxificados por conjugação com sulfato, glutationa ou glucuronídeo. Adicionalmente, tem sido bem descrito que os compostos fenólicos formados no fígado são transportados através do sangue para a medula óssea, onde se constituem substratos para peroxidases, como a mieloperoxidase (MPO) e ciclooxigenase (COX). Nesta localização são hidroxilados e/ou oxidados a quinonas e semiquinonas, metabólitos com alto potencial tóxico, por reagirem com estruturas nucleofílicas como DNA, RNA e proteínas; ou por gerarem espécies reativas de oxigênio que causam o estresse oxidativo (Thomas e cols., 1990; Kolachana e cols., 1993; Ross e cols., 1996). Também na medula o processo de detoxificação envolve a conjugação com sulfatos, glutationa ou glicuronídeos. No entanto, a sulfatação não é um mecanismo potente de detoxificação, devido à presença de níveis elevados de sulfatase na medula óssea, que podem quebrar os conjugados sulforados para fenóis livres (Low e cols., 1995). Contribuindo para detoxificação, a enzima $\mathrm{NAD}(\mathrm{P}) \mathrm{H}$ : quinona oxidoredutase (NQ01) presente na medula reduz as quinonas e semiquinonas a benzoquinonas (Ross e cols., 2000; Bauer e cols., 2003). Tem sido proposto que a relação entre a concentração de MPO e NQ01 pode representar o balanço entre bioativação e detoxificação, influenciando, desta forma, susceptibilidade à toxicidade por compostos fenólicos (Ganousis e cols., 1992). A biotransformação do benzeno é crucial para sua toxicidade. Estudos experimentais in vivo e in vitro têm demonstrado que as concentrações dos metabólitos do benzeno necessárias para os efeitos tóxicos ao sistema imune são menores que as requeridas pelo benzeno (Irons e cols., 1985; Ewens e cols., 1999; Fabiani e cols., 2001) e que polimorfismos nas enzimas envolvidas no processo determinam diferenças no quadro da intoxicação (Kim e cols., 2004; Ross, 2005; Fustinoni e cols., 2005)

Visto a relevância da toxicidade do benzeno, os métodos analíticos empregados para monitorização biológica devem ser precisos e apresentar alta 
sensibilidade para identificação de biomarcadores, mesmo em baixas condições de exposição. O emprego de método analítico inadequado pode fornecer dados errôneos na determinação de parâmetros toxicológicos importantes, como a relação entre exposição, dose-resposta e o efeito ("endpoint") (Ong e Lee, 1994). Desta forma, a investigação analítica caminha no sentido de desenvolver métodos mais sensíveis e precisos para determinação de marcadores biológicos que indiquem alterações fisológicas precocemente.

Uma grande variedade de métodos analíticos é utilizada para separação, quantificação e identificação dos produtos de biotransformação do benzeno (Schad e cols., 1992). A determinação da concentração biológica do benzeno e de seus produtos de biotransformação pode ser realizada em diferentes matrizes biológicas, entre as quais o ar exalado, o sangue e a urina. Análises do benzeno na respiração podem ser conduzidas com tubo coletor de ar exalado e sua subseqüente análise direta pode ser realizada por cromatografia gasosa (CG) ou cromatografia gasosa acoplada a espectrometria de massa (CGMS) (Brega e cols., 1990; Schad e cols., 1992; Lee e cols., 1993; Laurens e cols., 2002; Waidynatha e cols., 2004). Entretanto, análises em amostras de sangue ou urina são comumente empregadas (Ong e Lee, 1994). A preparação das amostras de urina e sangue para determinação dos compostos fenólicos geralmente envolve uma fase de hidrólise ácida ou enzimática, seguida de extração líquido-líquido em solvente orgânico. Nestes casos, os métodos espectrofotométricos são empregados para determinação de componentes fenólicos totais, enquanto que os cromatográficos são apropriados para determinação seletiva destes compostos. Acetilação, benzilação, benzoilação, alquilação, sililação são métodos que têm conquistado terreno na literatura para análises de cromatografia gasosa de fenóis (Fiamegos e cols., 2003).

Recentemente, desenvolvemos e validamos o método de CGMS para determinação simultânea de FE, HQ e CAT na urina, no qual a obtenção dos analítos da matriz foi realizada por hidrólise ácida dos compostos fenólicos conjugados e subseqüente extração usando microextração em fase sólida. Para tanto, os analítos foram extraídos pela submersão de uma fibra de 
coberta de poliacrilato polar $(85 \mu \mathrm{m})$ na urina $(\mathrm{pH} 3,0$, ajustado com ácido acético glacial) por 20 minutos com agitação magnética. Os compostos extraídos na fibra foram expostos ao reagente hexametildisilazano em fase de vapor por 20 minutos para obtenção dos derivados trimetilsililados. Este procedimento de derivação permitiu a formação de compostos mais apropriados para a análise cromatográfica, sem afetar a meia-vida da fibra. A espectrometria de massa foi realizada no modo de monitoramento seletivo de íns. Os limites de detecção foram $0,3 \mu \mathrm{g} / \mathrm{mL}$ para o $\mathrm{FE} ; 0,15 \mu \mathrm{g} / \mathrm{mL}$ para a $\mathrm{HQ}$ e $0,02 \mu \mathrm{g} / \mathrm{mL}$ para o CAT. As precisões inter e intra-ensaios também foram verificadas (coeficiente de variação menor que $8 \%$ ) com o uso de padrões deuterados (LOURENÇO, E.L.B.; FERREIRA, A.; PINTO, E.; YONAMINE, M.; FARSKY, S.H.P. On-Fiber derivatization of SPME extracts of Phenol, Hydroquinone and Catechol with GC-MS detection. Chromatographia, 2006).

Como já salientado anteriormente, os efeitos da intoxicação pelo benzeno sobre o sistema imune são graves e complexos e envolvem efeitos na produção, maturação e nas diferentes funções das células envolvidas nas respostas imunes (Woo e cols., 1989; Morimoto, 1993; Robinson e cols., 1997; Farris e cols., 1997; Bogadi-Sare e cols., 2000; Velasco-Lezama e cols., 2001).

O benzeno e seus metabólitos, especialmente as quinonas, são estimuladores in vitro e in vivo da diferenciação de granulócitos e promovem supressão da hematopoese in vivo (revisto em De Caprio, 1999). Tais observações provêm de estudos clínicos ou experimentais que mostraram que a exposição ao benzeno ou a seus metabólitos reduz o número de células da linhagem mononuclear no sangue periférico (Gill e cols., 1980; Snyder e cols., 1980; Green e cols., 1981; Cronkite e cols., 1989; Farris e cols., 1997), na medula e em orgãos linfóides secundários (Robinson e cols., 1997; Farris e cols., 1997; Kalf e cols., 2000; Boscolo e cols., 2000; Bogadi-Sare e cols., 2000; Velasco-Lezama, 2001).

A granulocitose induzida pelo benzeno, demonstrada in vivo por neutrofilia, tem sido atribuída à incompleta diferenciação celular, de mieloblasto a mielócito, com aumento no número de mielócitos. Este efeito ocorre devido à 
biotransformação do benzeno, sendo que a oxidação da $\mathrm{HQ}$ a p-benzoquinona pela MPO parece ser etapa fundamental. Os mecanismos envolvidos não estão bem determinados, mas parecem ser dependentes de diferentes vias de ativação do ciclo celular. Foi demonstrado in vitro que o solvente suprime o ciclo celular mediado por p53 e aumenta a expressão de p21, um inibidor de quinase ciclo dependente (Yoon e cols., 2002). Adicionalmente, o mecanismo da incompleta diferenciação granulocítica parece ser dependente da ativação de proteína quinase $\mathrm{C}$ e da subseqüente ativação da via da 5 -lipoxigenase $\mathrm{e}$ produção de leucotrieno D4 e sua interação ao receptor (Hazel e cols., 1996a; Hazel e Kalf, 1996). Adicionalmente, a HQ oxidada pela MPO também inibe a apoptose de mieloblastos, contribuindo para o efeito (Hazel e cols., 1996b). Além da modificação na produção e maturação de granulócitos, o benzeno e seus metabólitos fenólicos estimulam o "burst" respiratório de granulócitos humanos com geração de metabólitos ativos do oxigênio, por meio de um mecanismo que envolve fosfolipase $C$ cálcio-dependente, fosfolipase $D$ e proteína C quinase (Myhre e Fonnum, 2001). Este trabalho ratifica observações prévias de MacEachern e cols. (1992) que demonstraram que granulócitos e monócitos da medula óssea de camundongos intoxicados por benzeno apresentam produção de peróxido de hidrogênio e atividade quimiotáxica aumentadas.

Visto que os metabólitos fenólicos do benzeno alteram a maturação e as funções de leucócitos polimorfonucleares, investigamos se a exposição por período prolongado de tempo a estes compostos afeta o recrutamento destas células na vigência de resposta inflamatória inata.

Para tanto, ratos Wistar machos foram expostos à $\mathrm{HQ}$, FE ou veículo pela via intraperitoneal, na dose de $50 \mathrm{mg} / \mathrm{kg}, 13$ doses, uma vez ao dia com intervalos de 2 dias a cada 5 doses, sendo os ensaios realizados 24 horas após a última dose. Animais expostos ao veículo foram usados como controles. Quantificações dos números de leucócitos presentes na medula óssea ou na circulação mostraram que somente a exposição à $H Q$ acarretou neutrofilia, devido à acelerada mobilização destas células da medula, já que o número de células segmentadas na última etapa de maturação foi menor em animais 
expostos à $H Q$ que animais expostos ao FE ou ao veículo. Imagens da rede microcirculatória do mesentério, obtidas por ensaios de microscopia intravital, mostraram que os leucócitos circulantes de ratos expostos à $\mathrm{HQ}$ possuiam maiores capacidades de rolarem e aderirem à parede de vênulas pós-capilares. A investigação da capacidade de contração e dilatação dos vasos da microcirculação frente à noradrenalina e acetilcolina, respectivamente; a quantificação do número de mastócitos adjacentes às vênulas e suas habilidades de desgranulação em resposta ao composto 48/80; e a determinação da expressão de moléculas de adesão no endotoléio mostraram que as alterações na interação leucócito-endotélio não eram dependentes de modificações na reatividade vascular, nem da ação de mediadores químicos secretados por mastócitos, nem da expressão de ICAM-1, VCAM-1 ou PECAM1 no endotélio. No entanto, a maior interação com a parede vascular parece ser dependente, pelo menos em parte, da ativação dos neutrófilos circulantes, visualizados pelo decréscimo e acréscimo das expressões de L-selectina e $\beta 2$ integrinas, respectivamente. A maior mobilização de neutrófilo da medula para o compartimento periférico e seu estado de ativação alterado pode ter contribuído pelo maior número de neutrófilos no exsudato inflamatório coletado de um processo agudo (6 horas após injeção de glicogênio de ostra no subcutâneo dorsal - modelo da bolsa de ar). Em conjunto, os dados obtidos mostraram que a $\mathrm{HQ}$ altera a mobilização e ativação de neutrófilos, que resultam em uma reação exacerbada em reposta ao trauma inespecífico. Cabe salientar que apesar do $\mathrm{FE}$ ser biotransformado à $H Q$, a exposição ao $\mathrm{FE}$ resultou somente em aumento no número de leucócitos em comportamento "rolling", o qual não foi suficiente para alterar o processo inflamatório (MACEDO, SM; LOURENÇO, EL; BORELLI, P.; FOCK, RA; FERREIRA JM Jr; FARSKY, SH. Effect of in vivo phenol or hydroquinone exposure on events related to neutrophil delivery during an inflammatory response. Toxicology, 2006).

Além dos efeitos sobre a série granulocítica, o benzeno e seus derivados fenólicos alteram a produção e/ou maturação de células da linhagem mononuclear, especialmente os diferentes tipos de linfócitos, prejudicando a 
mobilização destas células para a circulação e suas funções específicas (MacEachern e cols., 1992; Farris e cols., 1997; Yoon e cols., 2001). O papel da $H Q$ nestes efeitos tem sido demonstrado após sua adição a células precursoras da produção linfocitária em cultura (King e cols., 1987; 1989; Li e cols., 1996; 1997; 1998; Pyatt e cols., 1998; 2000; McCue e cols., 2000; 2003) e pela redução do número de células $B$ progenitoras na medula e no baço de camundongos expostos à $H Q$ ou ao catecol (Wierda e Irons, 1982). Os mecanismos envolvidos são complexos e não bem compreendidos, e parecem depender das concentrações dos metabólitos nos diferentes compartimentos de maturação e função celular. Tem sido demonstrado que a $H Q$ inibe a progressão do ciclo celular (Li e cols, 1996, 1997; McCue e cols., 2003) e a atividade da ribonucleotídeo redutase (Li e cols., 1998; McCue e cols., 2000), bloqueando conseqüentemente, a linfoproliferação de linfócitos. Ainda, a administração in vitro de $\mathrm{HQ}$ reduz a produção de interleucina 2 (IL-2) e TNF por células $T$ e B cells, respectivamente, em um mecanismo dependente de NF-kappa B em resposta a vários estimulos (Pyatt e cols., 1998, 2000).

Com as fortes evidências dos metabólitos fenólicos do benzeno, especialmente a $\mathrm{HQ}$, sobre a série linfocitária, investigamos o papel deste metabólito sobre a capacidade de migração leucocitária, agora em vigência de um processo alérgico no pulmão.

Para tanto, os animais foram expostos à $\mathrm{HQ}(50 \mathrm{mg} / \mathrm{kg}$, i.p., 16 doses, diariamente, com intervalos de 2 dias a cada 5 doses) ou ao veículo, nas mesmas condições. No décimo dia após o início das exposições, os animais foram sensibilizados pela Ovalbumina (OVA; $10 \mu \mathrm{g} / 10 \mathrm{mg}$ de hidróxido de alumínio, via i.p.) e desafiados 13 dias mais tarde pela inalação do antígeno (solução de OVA a $1 \%$ em tampão fosfato salina, durante 15 minutos). Os experimentos foram sempre realizados 24 horas após a última dose de HQ. A quantificação do número de leucócitos no lavado bronco-alveolar (LBA), coletado 24 horas após o desafio, mostrou que a exposição à $H Q$ provocou redução acentuada no número de leucócitos, representada por decréscimos nos números de leucócitos mononucleares (MN) e PMN. A determinação da atividade da enzima MPO no tecido pulmonar, que reflete a quantidade de 
neutrófilos no tecido, mostrou que a exposição à $H Q$ comprometeu a chegada destas células no pulmão, uma vez que os valores encontrados em animais expostos à $H Q$ e ao veículo foram equivalentes. Estes efeitos não foram dependentes de modificações no número de leucócitos circulantes, nem da expressão das moléculas de adesão no leucócito (L-selectina e $\beta 2$ integrina) e no endotélio (ICAM-1, VCAM-1 e PECAM-1). No entanto, os ensaios subseqüentes mostraram que 0 efeito parece ser dependente de comprometimento na desgranulação de mastócitos mediada por lgE. Este hipótese foi levantada pelas seguintes observações: 1) a contração da traquéia in vitro estava reduzida em tecidos provenientes de animais expostos à $H Q$ e 2) a resposta anafilática cutânea foi menor em animais normais que receberam previamente soro de animais sensibilizados e expostos à $\mathrm{HQ}$ que em animais que receberam soro de animais sensibilizados e expostos ao veículo. É importante salientar que a proliferação de linfócitos do baço em resposta à OVA ou à Concanavalina $\mathrm{A}$ foi similar em células obtidas de animais expostos à $H Q$ ou ao veículo, excluindo possíveis efeitos sobre os mecanismos intracelulares envolvidos nas respostas específicas ou não específicas ao antígeno. Em conjunto, nossos dados mostram que a exposição à $H Q$, em doses que não modificam o leucograma, diminui o recrutamento leucocitário durante uma resposta alérgica, dependente da desgranulação mastocitária mediada por IgE (MACEDO, S.M.D; VAZ, S.C.M.; LOURENÇO, E.L.B.; DA GLÓRIA DE SOUZA, M.; CAVRIANI, G.; LIGEIRO-OLIVEIRA, A.P.; ALMEIDA, S.R.; TAVARES DE LIMA, W.; FARSKY, S.H.P. In vivo hydroquinone exposure inhibits leukocyte migration during an allergic lung inflammation in rats. Toxicology and Applied Pharmacology, enviado para publicação).

É de grande relevância ressaltar que, aparentemente, as doses dos compostos fenólicos usados nos trabalhos acima não foram tóxicas para os animais, uma vez que não observamos perda de peso corporal; o exame histológico do rim e fígado não evidenciou alterações em ambos os tecidos e as concentrações de alanina amino transaminase, aspartato aminotransferase 
e creatinina foram equivalentes em animais expostos à $\mathrm{HQ}$ e ao veículo (estando dentro da faixa de normalidade).

Em conjunto, os dados dos trabalhos apresentados acima mostram que a exposição a agentes fenólicos por período prolongado de tempo interfere na migração leucocitária para o foco de lesão. No entanto, os efeitos são distintos, dependendo da origem do processo inflamatório e do tecido lesado. É possível que estas diferenças estejam associadas aos diferentes mediadores químicos e às sinalizações intracelulares dos processos. Neste sentido, umas das linhas que trilham nossos estudos é a investigação dos efeitos dos xenobióticos sobre a produção de óxido nítrico, uma vez que tem sido demonstrado que o mediador participa de reações oxidativas após exposição ao benzeno e a seus produtos de biotransformação (Laskin e cols., 1995; 1996; Wu e cols., 1998; Tuo e cols., 1999a,b; Fabiani e cols., 2001) e sobre a secreção de interleucina4 (IL-4) e interleucina-13 (IL-13) por linfócitos T, mediadores envolvidos na sinalização da produção de anticorpos.

A literatura mostra que o FE não apresenta efeito sobre alguns parâmetros envolvidos na gênese da intoxicação por benzeno, mas que é capaz de atuar sinergicamente com a HQ (Kolachana e cols., 1993; Moran e cols, 1996; Henschler e cols., 1996). Como demonstramos que o FE não foi capaz de interferir com a migração neutrofílica na vigência de resposta inflamatória aguda inata, uma outra linha de investigação do laboratório visa avaliar os efeitos da associação dos compostos fenólicos nos parâmetros por nós observados. Para tanto, caracterizamos a menor dose de $\mathrm{HQ}$ capaz de interferir com o processo (5 mg/kg) e a injetaremos com a mesma dose de FE, utilizando os mesmos delineamentos experimentais descritos acima. 


\section{REFERÊNCIAS BIBLIOGRÁFICAS}

ADDISON, W. Experimental and practical researches on the structure and function of blood corpuscles on inflammation and on the origin and nature of tubercules in the lungs. Trans. Prov. Med. Surg. Assoc., v.11, p.223-306, 1843.

AKTAN, F. iNOS-mediated nitric oxide production and its regulation. Life Sci., v.75, p.639-653, 2004.

ALDERTON, W.K.; COOPER, C.E.; KNOWLES, R.G. Nitric oxide synthases: structure, function and inhibition. Biochem. J., v.357, n.3, p.593-615, 2001.

ALMAWI, W.Y.; MELEMEDJIAN, O.K. Negative regulation of nuclear factorkappa B activation and function by glucocorticoids. J. Mol. Endocrinol., v.28, n.2, p.69-78, 2002.

ALON, R.; ETIZIONI, A. LAD-III, a novel group of leukocyte integrin activation deficiencies. Trends Immunol., v.24, p.561-566, 2003.

ANDRÉ, P. P-selectin in haemostasis. Br.J. Haematol., v.126, n.3, p.298-306, 2004.

ARNAOUT, M.A.; PITT, J.; COHEN, H.J.; MELAMED, J.; ROSEN, F.S.; COLTEN, H.R. Deficiency of a granulocyte-membrane glycoprotein (gp150) in a boy with recurrent bacterial infections. N. Engl. J. Med., v.306, n.12, p.693-699, 1982.

ARNDT, H.; RUSSELL, J.B.; KUROSE, I.; KUBES, P.; GRANGER, D.N. Mediators of leukocyte adhesion in rat mesenteric venules elicited by inhibition of nitric oxide synthesis. Gastroenterology, v.105, n.3, p.675-680, 1993. 
ARNOUT, M.A.; MAHALINGAM, B.; XIONG, J.-P. Integrin structure, allostery, and bidirectional signaling. Ann. Rev. Cell Develop. Biol., v.21, p.381-410, 2005.

BARNES, P.J. Anti-inflammatory actions of glucocorticoids: molecular mechanisms. Clin. Sci., v.94, n.6, p.557-572, 1998.

BARTHOLOME, B.; SPIES, C.M.; GABER, T.; SCHUCHMANN, S.; BERKI, T.; KUNKEL, D.; BIENERT, M.; RADBRUCH, A.; BURMESTER, G.R.; LAUSTER, R.; SCHEFFOLD, A.; BUTTGEREIT, F. Membrane glucocorticoid receptors (mGCR) are expressed in normal human peripheral blood mononuclear cells and up-regulated after in vitro stimulation and in patients with rheumatoid arthritis. FASEB J., v.18, n.1, p.70-80, 2004.

BAUER, A.K.; FAIOLA, B.; ABERNETHY, D.J.; MARCHAN, R.; PLUTA, L.J.; WONG, V.A.; ROBERTS, K.;JAISWAL, A.K.; GONZALEZ, F.J.; BUTTERWORTH, B.E.; BORGHOFF, S.; PARKINSON, H.; EVERITT, J.; RECIO, L. Genetic susceptibility to benzene-induced toxicity: role of NADPH: quinone oxidoreductase-1. Cancer Res. v.63, n.5, p.929-935, 2003.

BECK, P.L.; XAVIER, R.; WONG, J.; EZEDI, I.; MASHIMO, H.; MIZOGUCHI, A.; MIZOGUCHI, E.; BHAN, A.K.; PODOLSKY, D.K. Paradoxical roles of different nitric oxide synthase isoforms in colonic injury. Am. J. Physiol. Gastrointest. Liver Physiol., v.286, n.1, p.G137-G147, 2004.

BEVILACQUA, M.P.; POBER, J.S.; MENDRICK, D.L.; COTRAN, R.S.; GIMBRONE JÚNIOR, M.A. Identification of an inducible endothelial-leukocyte adhesion molecule. Proc. Natl. Acad. Sci. USA, v.84, n.24, p.9238-9242, 1987.

BOCHNER, BS. Adhesion molecule as therapeutic targets. Immunol. Allergy Clin. North Am., v.24, n.4, p.615-630, 2004. 
BOGADI-SARE, A.; ZAVALIC, M.; TROSIC, I.; TURK, R.; KONTOSIC, I.; JELCIC, I. Study of some immunological parameters in workers occupation exposed to benzene. Int. Arch. Occup. Environ. Health, v.73, n.6, p.397-400, 2000.

BOGDAN, C. Nitric Oxide and the regulation of gene expression. Trends Cell Biol., v.11, p.66-75, 2001.

BONFANTI, R.; FURIE, B.C.; FURIE, B.; WAGNER, D.D. PADGEM (GMP140) is a component of Weibel-Palade bodies of human endothelial cells. Blood, v.73, n.5, p.1109-1112, 1989.

BORDERIE, D.; HILLIQUIN, P.; HERNVANN, A.; KAHAN, A.; MENKES, C.J.; EKINDJIAN, O.G. Nitric oxide synthase is expressed in the lymphomononuclear cells of synovial fluid in patients with rheumatoid arthritis. J. Rheumatol., v.26, n.10, p.2083-2088, 1999.

BOSCOLO, P.; DI GIOACCHINO, M.; SABBIONI, E.; DI GIACOMO, F.; REALE, M.; VOLP, A.R.; DI SCIASCIO, M.B.; CONTI, P.; GIULIANO, G. Lymphocyte subpopulations, cytokines and trace elements in assymptomatic atopic women exposed to an urban environment. Life Sci., v.67, n.10, p.1119-1126, 2000.

BRASIL. Segurança e medicina do trabalho: lei $n^{\circ} 6514$, de 22 de dezembro de 1977. 48.ed. São Paulo: Editora Atlas, 2001. 605p.

BREGA, A.; PRANDINI, P.; AMAGLIO, C.; PAFUMI, E. Determination of phenol, m-, o- and p-cresol, p-aminophenol and nitrophenol in urine by highperformance liquid chromatography. J. Chromatogr., v.535, p.311-316, 1990. 
BUNTING, M.; HARRIS, E.S.; MCINTYRE, T.M.; PRESCOTT, S.M.; ZIMMERMAN, G.A. Leukocyte adhesion deficiency syndromes: adhesion and tethering defects involving beta 2 integrins and selectin ligands. Curr. Opin. Hematol., v.9, p.30-35, 2002.

BURGER, P.C.; WAGNER, D.D. Platelet P-selectin facilitates atherosclerotic lesion development. Blood, v.101, n.7, p.2661-2666, 2003.

BUTCHER, E.C.; PICKER, L.J. Lymphocyte homing and homeostasis. Science, v.272, n.5258, p.60-66, 1996.

CANTY, J.M. Nitric oxide and short-term hibernation: friend or foe? Circ. Res., v.87, p.85-87, 2000.

CARAMORI, G.; ADCOCK, I. Anti-inflammatory mechanisms of glucocorticoids targeting granulocytes. Curr. Drug Targets Inflamm. Allergy, v.4, n.4, p.455463, 2005.

CARION, A.; DOMENECH, J.; HERAULT, O.; BENBOUBKER, L.; CLEMENT, N.; BERNARD, M.C.; DESBOIS, I.; COLOMBAT, P.; BINET, C. Decreased stroma adhesion capacity of CD34+ progenitor cells from mobilized peripheral blood is not lineage- or stage-specific and is associated with low beta 1 and beta 2 integrin expression. J. Hematother. Stem. Cell. Res., v.11 n.3, p.491500, 2002.

CAVALCANTI, D.M.H.; LOTUFO, C.M.C.; BORELLI, P.; MARKUS, R.P.; FARSKY, S.H.P. Adrenal deficiency alters mechanisms of neutrophil mobilization. Molec. Cell. Endocrinol., 2006.

CHAN, J.Y.; WATT, S.M. Adhesion receptors on haematopoietic progenitor cells. Br. J. Haematol., v.112, n.3, p.541-557, 2001. 
CHATILA, T.A.; GEHA, R.S.; ARNAOUT, M.A. Constitutive and stimulusinduced phosphorylation of CD11/CD18 leukocyte adhesion molecules. J. Cell. Biol., v.109, n.6 (pt.2), p.3435-3444, 1989.

CHEPIGA, T.A.; YANG, C.S.; SNYDER, R. Benzene metabolism in two purified reconstituted rat hepatic mixed functions oxidase systems. In: WITTMER, C.M.; SNYDER, R.; JOLLOW, D.J., eds. Biological reactive intermediates IV. molecular and cellular effects and their impact on human health. New York: Plenum Press, 1991. p.261-265.

COHNHEIM, J. Über entzundung und eiterung. Virchows Arch. Pathol. Anat., v.40, p.1-79, 1867.

COLASANTI, M.; SUZUKI, H. The dual personality of NO. Trends Pharmacol. Sci., v.21, p.249-252, 2000.

CRONKITE, E.P.; DREW, R.T.; INOUE, T.; HIRABAYASHI, Y.; BULLIS, J.E. Hematotoxicity and carcinogenicity of inhaled benzene. Environ. Health Perspect., v.82, p.97-108, 1989.

CROWLEY, C.A.; CURNUTTE, J.T.; ROSIN, R.E.; ANDRE-SCHWARTZ, J.; GALLIN, J.I.; KLEMPNER, M.; SNYDERMAN, R.; SOUTHWICK, F.S.; STOSSEL, T.P.; BABIOR, B.M. An inherited abnormality of neutrophil adhesion. Its genetic transmission and its association with a missing protein. N. Engl. J. Med. v.302, n.21, p.1163-1168, 1980.

DANA, N.; ARNAOUT, M.A. Leucocyte adhesion molecules (CD11/CD18) deficiency. In: KAZATCHKINE, M. (ed.). Bailliere's clinical immunology and allergy. London: Baillier Tindall, 1988. v.2, cap.2, p.453-476.

DAWN, B.; BOLLI, R. Role of nitric oxide in myocardial preconditioning. Ann. New York Acad. Sci., v.962, p.18-41, 2002. 
DE CAPRIO, A.P. The Toxicology of hydroquinone - Relevance to occupational and environmental exposure. Crit. Rev. Toxicol., v.29, n.3, p.283-330, 1999.

DEDEOGLU, I.O.; SPRINGATE, J.E. Effect of nitric oxide inhibition on kidney function in experimental renovascular hypertension. Clin. Exp. Hypertens., v.23, n.3, p.267-275, 2001.

DeLISSER, H.M.; CHRISTOFIDOU-SOLOMIDOU, M.; SUN, J.; NAKADA, M.T.; SULLIVAN, K.E. Loss of endothelial surface expression of E-selectin in a patient with recurrent infections. Blood, v.94, n.3, p.884-894, 1999.

DIMITROFF, C.J.; LEE, J.Y.; SCHOR, K.S.; SANDMAIER, B.M.; SACKSTEIN, R. Differencial L-selectin binding activities of human hematopoietic cell Lselectin ligands HCELL and PSGL-1. J. Biol. Chem., v.276, n.50, p.4762347631, 2001.

DOERSCHUK, C.M.; TASAKA, S.; WANG, Q. CD11/CD18-dependent and independent neutrophil emigration in the lungs: how do neutrophils know which route to take? Am. J. Respir. Cell Mol. Biol., v.23, n.2, p.133-136, 2000.

DOERSCHUK, C.M. Mechanisms of leukocyte sequestration in inflamed lungs. Microcirculation, v.8, n.2, p.71-88, 2001.

DUNCAN, G.; ANDREW, D.P.; TAKIMOTO, H.; KAUFMAN, S.A.; YOSHIDA, H.; SPELLBERG, J.; LUIS DE LA POMPA, J.; ELIA, A.; WAKEHAM, A.; KARAN-TAMIR, B.; MULLER, W.A.; SENALDI, G.; ZUKOWSKI, M.M.; MAK, T.W. Genetic evidence for functional redundancy of Platelet/Endothelial cell adhesion molecule-1 (PECAM-1): CD31-deficient mice reveal PECAM-1dependent and PECAM-1-independent functions. J. Immunol., v.162, n.5, p.3022-3030, 1999. 
DUNLOP, L.C.; SKINNER, M.P.; BENDALL, L.J.; FAVALORO, E.J.; CASTALDI, P.A.; GORMAN, J.J.; GAMBLE, J.R.; VADAS, M.A.; BERNDT, M.C. Characterization of GMP-140 (P-selectin) as a circulating plasma protein. J . Exp. Med., v.175, n.4, p.1147-1150, 1992.

DUTROCHET, M.H. Recherches anatomiques et physiologuiques sur la structure intime des animaux et des vegetaus, et sur leur motilité. Paris Bailliere et Fils, 1824.

EHRHARDT, C.; KNEUER, C.; BAKOWSKY, U. Selectins- an emerging target for drug delivery. Adv. Drug. Deliv. Rev., v.56, n.4, p.527-549, 2004.

ETZIONI, A.; DOERSCHUK, C.M.; HARLAN, J.M. Of man and mouse: leukocyte and endothelial adhesion molecule deficiencies. Blood, v.94, n.10, p.3281-3288, 1999.

EWENS, S.; WULFERINK, M.; GOEBEL, C.; GLEICHMANN, E. T-cell dependent immune reactions to reactive benzene metabolites in mice. Arch. Toxicol., v.73, p.159-167, 1999.

FABIANI, R.; DE BARTOLOMEO, A.; ROSIGNOLI, P.; SCAMOSCI, M.; LEPORE, L.; MORG, G. Influence of culture conditions on the DNA-damaging effect of benzene and its metabolites in human peripheral blood mononuclear cells. Environ. Mol. Mutagen., v.37, n.1, p.1-6, 2001.

FARRIS, G.M.; ROBINSON, S.N.; WONG, B.A.; WONG, V.A.; HANH, W.P.; $\mathrm{SHAH}, \mathrm{R}$. Effects of benzene on splenic, thymic, and femoral lymphocytes in mice. Toxicology, v.28, n.118, p.137-148, 1997.

FARSKY, S.H.P.; SANNOMIYA, P.; GARCIA-LEME, J. Secreted glucocorticoids regulate leukocyte-endothelial interactions in inflammation: $A$ direct vital microscopic study. J. Leukoc. Biol., v.57, p.379-386, 1995. 
FARSKY, S.H.P.; BORELLI, P.; FOCK, R.A.; PROTO, S.Z.; FERREIRA, J.M.C.; MELLO, S.B.V. Chronic blockage of nitric oxide biosynthesis in rats: effect on leukocyte endothelial interaction and on leukocyte recruitment. Inflamm. Res., v. 53, p.442-542, 2004.

FASSBENDER, K.; KAPTUR, S.; BECKER, P.; GROSCHEL, J.; SCHMIDT, R.; HENNERICI, M. Inverse association between endogenous glucocorticoid secretion and L-selectin (CD62L) expression in trauma patients. Life Sci., v.65, n.23, p.2471-2480, 1999.

FESSLER, B.J.; PALIOGIANNI, F.; HAMA, N.; BALOW, J.E.; BOUMPAS, D.T. Glucocorticoids modulate CD28 mediated pathways for interleukin 2 production in human T cells: evidence for posttranscriptional regulation. Transplantation, v.62, n.8, p.1113-1118, 1996.

FIAMEGOS, Y.C.; NANOS, C.G.; PILIDIS, G.A.; STALIKAS, C.D. Phasetransfer catalytic determination of phenols as methylated derivatives by gas chromatography with flame ionization and mass-selective detection. J. Chromatogr. A, v.983, p.215-223, 2003.

FLOWER, R.J.; PARENTE, L.; PERSICO, P.; SALMON, J.A. A comparison of the acute inflammatory response in adrenalectomised and sham-operated rats. Br. J. Pharmacol., v.87, n.1, p.57-62, 1986.

FORS, B.P.; GOODARZI, K.; ANDRIAN, U.H. L-selectin shedding is independent of its subsurface structures and topographic distribution. J. Immunol., v.167, n.7, p.3642-3651, 2001.

FORSTER, J.; BEEBE, P.; WANG, H.; WOOD, J.G. The effect of nitric oxide inhibition on blood pressure depends on rat strain. J. Surg. Res., v.96, n.2, p.218-223, 2001. 
FUSTINONI, S.; CONSONNI, D.; CAMPO, L.; BURATTI, M.; COLOMBI, A.; PESATORI, A.C.; BONZINI, M.; BERTAZZI, P.A.; FOA, V.; GARTE, S.; FARMER, P.B.; LEVY, L.S.; PALA, M.; VALERIO, F.; FONTANA, V.; DESIDERI, A.; MERLO, D.F. Monitoring low benzene exposure: comparative evaluation of urinary biomarkers, influence of cigarette smoking, and genetic polymorphisms. Cancer Epidemiol. Biomarkers Prev., v.14, n.9, p.2237-2244, 2005.

GABOURY, J.; WOODMAN, R.C.; GRANGER, D.N.; REINHARDT, P.; KUBES, P. Nitric oxide prevents leukocyte adherence: role of superoxide. Am. J. Physiol., v.265, n.3 (pt.2), p.H862-H867, 1993.

GAHMBERG, C.G.; TOLVANEN, M.; KOTOVUORI, P. Leukocyte adhesionstructure and function of human leukocyte beta2-integrins and their cellular ligands. Eur. J. Biochem., v.245, n.2, p.215-232, 1997.

GALLATIN, W.M.; WEISSMAN, I.L.; BUTCHER, E.C. A cell-surface molecule involved in organ-specific homing of lymphocytes. Nature, v.304, n.5921, p.3044, 1983.

GANOUSIS, L.G.; GOON, D.; ZYGLEWSKA, T.; WU, K.K.; ROOS, D. Cellspecific metabolism in mouse bone marrow strome: studies if activation and detoxification of benzene metabolites. Mol. Pharmacol., v.42, p.1118-1125, 1992.

GARABRANT, D.H.; DUMAS, C. Epidemiology of organic solvents and connective tissue disease. Arthritis Res., v.2, n.1, p.5-15, 2000.

GENG, J.G.; CHEN, M.; CHOU, K.C. P-selectin cell adhesion molecule in inflammation, thrombosis, cancer growth and metastasis. Curr. Med. Chem., v.11, n16, p.2153-2160, 2004. 
GILL, D.P.; JENKINS, V.R.; KEMPEN, R.R.; ELLIS, S. The importance of pluripotential stem cells in benzene toxicity. Toxicology, v.16, n.2, p.163-171, 1980.

GONZALEZ-AMARO, R.; SANCHEZ-MADRID, F. Cell adhesion molecules: selectins and integrins. Crit. Rev. Immunol., v.19, n.5/6, p.389-429; 1999.

GOULDING, N.J. The molecular complexity of glucocorticoid actions in inflammation - a four-ring circus. Curr. Opin. Pharmacol., v.4, n.6, p.629-636, 2004.

GRALEWICS, S. Organic solvents and time-dependent sensitization. Int. J. Occup. Med. Environ. Health, v.12, n.4, p.371-381, 1999.

GRANGER, D.N.; KUBES, P. The microcirculation and inflammation: modulation of leukocyte-endothelial cell adhesion. J. Leukoc. Biol., v.55, n.5, p.662-675, 1994.

GREEN, J.D.; SNYDER, C.A.; LO BUE, J.; GOLDSTEIN, B.D.; ALBERT, R.E. Acute and chronic dose/response effects of inhaled benzene on multipotential hematopoietic stem (CFU-S) and granulocyte/macrophage progenitor (GMCFU-C) cells in CD-1 mice. Toxicol. Appl. Pharmacol., v.58, n.3, p.492-503, 1981.

GUZZO, M.L.; FARSKY, S.H.P.; DE NUCCI, G.; ANTUNES, E.; SILVA, M.A.G. VERÍSSIMO DE MELLO, S.B. Role of kinins and nitric oxide on the rabbit arthrits induced by Bothrops jararaca venom. Toxicon, v. 38, n.11, p.15351546, 2000.

HADDAD, J.J.; SAADE, N.E.; SAFIEH-GARABEDIAN, B. Cytokines and neuroimmune-endocrine interactions: a role for the hypothalamic-pituitary-adrenal revolving axis. J. Neuroimmunol., v.133, n.1/2, p.1-19, 2002. 
HAFEZI-MOGHADAM, A.; SIMONCINI, T.; YANG, Z.; LIMBOURG, F.P.; PLUMIER, J.C.; REBSAMEN, M.C.; HSIEH, C.M.; CHUI, D.S.; THOMAS, K.L.; PROROCK, A.J.; LAUBACH, V.E.; MOSKOWITZ, M.A.; FRENCH, B.A.; LEY, K.; LIAO, J.K. Acute cardiovascular protective effects of corticosteroids are mediated by non-transcriptional activation of endothelial nitric oxide synthase. Nat. Med., v.8, n.5, p.473-479, 2002.

HARTWELL, D.W.; MAYADAS, T.N.; BERGER, G.; FRENETTE, P.S.; RAYBURN, H.; HYNES, R.O.; WAGNER, D.D. Role of P-selectin cytoplasmic domain in granular targeting in vivo and in early inflammatory responses. J. Cell Biol., v.143, n.4, p.1129-1141, 1998.

HAYASHI, R.; WADA, H.; ITO, K.; ADCOCK, I.M. Effects of glucocorticoids on gene transcription. Eur. J. Pharmacol., v.500, n.1/3, p.51-62, 2004.

HAZEL, B.A.; O'CONNOR, A.; NICULESCU, R.; KALF, G.F. Induction of granulocytic differentiation in a mouse model by benzene and hydroquinone. Environ. Health Perspect., v.104, suppl.6, p.1257-1264, 1996a.

HAZEL, B.A.; KALF, G.F. Induction of granulocytic differentiation in myeloblasts by hydroquinone, a metabolite of benzene involves the leukotriene D4 receptor. Recept. Signal Transduct., v.6, n.1, p.1-12, 1996.

HAZEL, B.A.; BAUM, C.; KALF, G.F. Hydroquinone, a bioreactive metabolite of benzene, inhibits apoptosis in myeloblasts. Stem Cells, v.14, n.6, p.730-742, 1996b.

HEBEDA, C.B.; MELLO, S.B.V.; FARSKY, S.H.P. Mechanisms involved on inhibition of neutrophil recruitment by chronic blockage of nitric oxide synthase. Inflamm. Res., suppl.2, p.S169, 2005. 
HENSCHLER, R.; GLATT, H.R.; HEYWORTH, C.M. Hydroquinone stimulates granulocyte-macrophage progenitor cells in vitro and in vivo. Environ. Health Perspect., v.104, suppl.6, p.1271-1274, 1996.

HICKEY, M.J.; GRANGER, D.N.; KUBES, P. Inducible nitric oxide synthase (iNOS) and regulation of leucocyte/endothelial cell interactions: studies in iNOSdeficient mice. Acta Physiol. Scand., v.173, p.119-126, 2001.

HICKEY, M.J.; SHARKEY, K.A.; SIHOTA, E.G.; REINHARDT, P.H.; MACMICKING, J.D.; NATHAN, C.; KUBES, P. Inducible nitric oxide synthasedeficient mice have enhanced leukocyte-endothelium interactions in endotoxemia. FASEB J., v.11, n.12, p.955-964, 1997.

HOBBS, A.J.; HIGGS, A.; MONCADA, S. Inhibition of nitric oxide synthase as a potential therapeutic target. Annu. Rev. Pharmacol. Toxicol., v.39, p.191-220, 1999 .

HOGG, N.; HENDERSON, R.; LEITINGER, B.; MCDOWALL, A.; PORTER, J.; STANLEY, P. Mechanisms contributing to the activity of integrins on leukocytes. Immunol. Rev., v.186, p.164-171, 2002.

HUO, Y.; LEY, K. Adhesion molecules and atherogenesis. Acta Physiol. Scand., v.173, n.1, p.35-43, 2001.

IALENTI, A.; IANARO, A.; MAFFIA, P.; SAUTEBIN, L.; DI ROSA, M. Nitric oxide inhibits leucocyte migration in carrageenin-induced rat pleurisy. Inflamm. Res., v.49, n.8, p.411-417, 2000.

IRONS, R.D. Quinones as toxic metabolites of benzene. J. Toxicol. Environ. Health, v.16, p.673-678, 1985. 
JAVELAUD, B.; VIAN, L.; MOLLE, R.; ALLAIN, P.; ALLEMAND, B.; ANDRE, B.; BARBIER CHURET, A.M.; DUPUIS, J.; GALAND, M.; MILLET, F.; TALMON, J.; TOURON, C.; VAISS, M.; VECHAMBRE, D.; VIEULES, M.; VIVER, D. Benzene exposure in car mechanics and road tanker drivers. Int. Arch. Occup. Environ. Health, v.71, n.4, p.277-288,1998.

JIMÉNEZ-ALTAYÓ, F.; BRIONES, A.M.; GIRALDO, J.; PLANAS, A.M.; SALAICES, M.; VILA, E. Increased superoxide anion production by IL-1ß impairs nitric oxide mediated relaxation in resistance arteries. J. Pharmacol. Exp. Ther., v.316, n.1, p.42-52, 2006.

KALF, G.F. Utility of a mouse model for studying the effects of benzene on myeloid lineage: effects of hidroquinone on a model myeloid system. J. Toxicol. Environ. Health A, v.61, n.5/6, p.399-411, 2000.

KALF, G.F.; RENZ, J.F.; NICULESCU, R. p-benzoquinone, a reactive metabolite of benzene, prevents processing of pro-interleukins-1 alpha and -1 beta to active cytokines by inhibition of the processing enzymes, calpain, a interleukin-1 beta converting enzyme. Environ. Health Perspect., v.104, suppl.6, p.1251-1256, 1996.

KANAME, H.; MORI, Y.; SUMIDA, Y.; KOJIMA, K.; KUBO, C.; TASHIRO, N. Changes in the leukocyte distribution and surface expression of adhesion molecules induced by hypothalamic stimulation in the cat. Brain Behav. Immun., v.16, n.4, p.351-367, 2002.

KIM, L.T.; YAMADA, K.M. The regulation of expression of integrin receptors.

Proc. Soc. Exp. Biol. Med., v.214, n.2, p.123-131, 1997.

KIM, S.Y.; CHOI, J.K.; CHO, Y.H.; CHUNG, E.J.; PAEK, D.; CHUNG, H.W. Chromosomal aberrations in workers exposed to low levels of benzene: association with genetic polymorphisms. Pharmacogenetics, v.14, n.7, p.453463, 2004. 
KING, A.G.; LANDRETH, K.S.; WIERDA, D. Hydroquinone inhibits bone marrow pre-B cell maturation in vitro. Mol. Pharmacol., v.32, v.6, v.807-812, 1987.

KING, A.G.; LANDRETH, K.S.; WIERDA, D. Bone marrow stromal cell regulation of B-lymphopoiesis. II. Mechanisms of hydroquinone inhibition of preB cell maturation. J. Pharmacol. Exp. Ther., v.250, v.2, p.582-590, 1989.

KLUGER, M.S. Vascular endothelial cell adhesion and signaling during leukocyte recruitment. Adv. Dermatol., v.20, p.163-201, 2004.

KOLACHANA, P.; SUBRAHMANYAM, V.V.; MEYER, K.B.; ZHANG, L.; SMITH, M.T. Benzene and its phenolic metabolites produce oxidative DNA damage in HL60 cells in vitro and in the bone marrow in vivo. Cancer Res., v.53, p.10231026, 1993.

KOSKINEN, K.; VAINIO, P.J.; SMITH, D.J.; PIHLAVISTO, M.; YLAHERTTUALA, S.; JALKANEN, S.; SALMI, M. Granulocyte transmigration through the endothelium is regulated by the oxidase activity of vascular adhesion protein-1 (VAP-1). Blood, v.103, n.9, p.3388-3395, 2004.

KUBES, P.; KANWAR, S.; NIU, X.F.; GABOURY, J.P. Nitric oxide synthesis inhibition induces leukocyte adhesion via superoxide and mast cells. FASEB J., v.7, n.13, p.1293-1299, 1993.

KUBES, P.; KUROSE, I.; GRANGER, D.N. NO donors prevent integrin-induced leukocyte adhesion but not $\mathrm{P}$-selectin-dependent rolling in postischemic venules. Am. J. Physiol., v.267, n.3 (pt.2), p.H931-937, 1994.

KUBES, P.; SUZUKI, M.; GRANGER, D.M. Nitric oxide: an endogenous modulator of leukocyte adhesion. Proc. Natl. Acad. Sci. USA, v.88, p.64516455, 1991. 
KUHLENCORDT, P.J.; ROSEL, E.; GERSZTEN, R.E.; MORALES-RUIZ, M.; DOMBKOWSKI, D.; ATKINSON, W.J.; HAN, F.; PREFFER, F.; ROSENZWEIG, A.; SESSA, W.C.; GIMBRONE JÚNIOR, M.A.; ERTL, G.; HUANG, P.L. Role of endothelial nitric oxide synthase in endothelial activation: insights from eNOS knockout endothelial cells. Am. J. Physiol. Cell Physiol., v.286, n.5, p.C1195C1202, 2004.

LAROUX, F.S.; LEFER, D.J.; KAWACHI, S.; SCALIA, R.; COCKRELL, A.S.; GRAY, L.; VAN DER HEYDE, H.; HOFFMAN, J.M.; GRISHAM, M.B. Role of nitric oxide in the regulation of acute and chronic inflammation. Antioxid. Redox Signal, v.2, p.391-396, 2000.

LASKIN, D.L.; HECK, D.E.; PUNJABI, C.J.; LASKIN, J.D. Role of nitric oxide in hematosuppression and benzene-induced toxicity. Environ. Health Perspect., v.104, n.6, p.1283-1287, 1996.

LASKIN, J.D.; RAO, N.R.; PUNJABI, C.J.; LASKIN, D.L.; SNYDER, R. Distinct actions of benzene and its metabolites on nitric oxide production by bone marrow leukocytes. J. Leukoc. Biol., v.57, n.3, p.422-426, 1995.

LAURENS, J.B.; MBIANDA, X.Y.; SPIES, J.H., UBBINK, J.B., VERMAAK, W.J. Validated method for quantitation of biomarkers for benzene and its alkylated analogues in urine. J. Chromatogr. B, v.774, n.173-185, 2002.

LEE, B.L.; ONG, H.Y.; SHI, C.Y.; ONG, C.N. Simultaneous determination of hydroquinone, catechol and phenol in urine using high-performance liquid chromatography with fluorimetric detection. J. Chromatogr., v.619, n. 2, p.259266, 1993.

LEECH, M., HUTCHINSON, P.; HOLDSWORTH, S.R.; MORAND, E.F. Endogenous glucocorticoids modulate neutrophil migration and synovial Pselectin but not neutrophil phagocytic or oxidative function in experimental arthritis. Clin. Exp. Immunol.,v.112, n.3, p.383-388, 1998. 
LEFER, D.J.; JONES, S.P.; GIROD, W.G.; BAINES, A.; GRISHAM, M.B.; COCKRELL, A.S.; HUANG, P.L.; SCALIA, R. Leukocyte-endothelial cell interactions in nitric oxide synthase-deficient mice. Am. J. Physiol., v.276, n.6 (pt.2), p.H1943-H1950, 1999.

LEME, J.G.; SCHAPOVAL, E.E. Stimulation of the hypothalamo-pituitaryadrenal axis by compounds formed in inflamed tissue. Br. J. Pharmacol., v.53, n.1, p.75-83, 1975.

LEONE, M.; BOUtIERE-ALBANES, B.; VALETTE S.; CAMOIN-JAU, L.; BARRAU, K.; ALBANESE, J.; MARTIN, C.; DIGNAT-GEORGE, F. Cell adhesion molecules as a marker eflecting the reduction of endothelial activation induced by glucocorticoids. Shock, v.21, n.4, p.311-314, 2004.

LI, Q.; GEISELHART, L.; MITTLER, J.N.; MUDZINSKI, S.P.; LAWRENCE, D.A.; FREED, B.M. Inhibition of human T lymphoblast proliferation by hydroquinone. Toxicol. Appl. Pharmacol., v.139, n.2, p.317-323, 1996.

LI, Q.; AUBREY, M.T.; CHRISTIAN, T.; FREED, B.M. Differential inhibition of DNA synthesis in human $T$ cells by the cigarette tar components hydroquinone and catechol. Fundam. Appl. Toxicol., v.38, n.2, p.158-165, 1997.

LI, Q.; KASTEN-JOLLY, J.; YEN, Y.; FREED, B.M. Reversal of hydroquinonemediated suppression of $T$ cell proliferation by transfection of the M2 subunit of ribonucleotide reductase. Toxicol. Appl. Pharmacol., v.150, n.1, p.154-157, 1998.

LOUIN, G.; MARCHAND-VERRECCHIA, C.; PALMIER, B.; PLOTKINE, M.; JAFARIAN-TEHRANI, M. Selective inhibition of Inducible nitric oxide synthase reduces neurological deficit but not cerebral edema following traumatic brain injury. Neuropharmacology, v.50, n.2, p.182-190, 2006. 
LOURENÇO, E.L.B.; FERREIRA, A.; PINTO, E.; YONAMINE, M.; FARSKY, S.H.P. On-Fiber derivatization of SPME extracts of Phenol, Hydroquinone and Catechol with GC-MS detection. Chromatographia, 2006.

LOW, L.K.; LAMBERT, C.E.; MEEKS, J.R.; NARO, P.A.; MACKERER, C.R. Tissue-specific metabolismo $f$ benzene in Zymbal gland and other solid tumor target tissues in rats. J. Am. Coll. Toxicol., v.14, p.40-60, 1995.

LU, N.Z.; CIDLOWSKI, J.A. The origin and funtions of multiple human glucocorticoid receptor isoforms. Ann. N. Y. Acad. Sci., v.1024, p.102-123, 2004.

LUHN, K.; WILD, M.K.; ECKHARDT, M.; GERARDY-SCHAHN, R.; VESTWEBER, D. The gene defective in leukocyte adhesion deficiency II encodes a putative GDP-fucose transporter. Nat. Genet., v.28, n.1, p.69-72, 2001.

LUSCINSKAS, F.W.; MA, S.; NUSRAT, A.; PARKOS, C.A.; SHAW, S.K. The role of endothelial cell lateral junctions during leukocyte trafficking. Immunol. Rev., v.186, p.57-67, 2002.

MACEACHERN, L.; SNYDER, R.; LASKIN, D.L. Alterations in the morphology and functional activity of bone marrow phagocytes following benzene treatment of mice. Toxicol. Appl. Pharmacol., v.117, n.2, p.147-154, 1992.

MACEDO, S.M.; LOURENÇO, E.L.; BORELLI, P.; FOCK, R.A.; FERREIRA, J.M. Jr; FARSKY, S.H.P. Effect of in vivo phenol or hydroquinone exposure on events related to neutrophil delivery during an inflammatory response. Toxicology, 2006. 
MACEDO, S.M.D; VAZ, S.C.M.; LOURENÇO, E.L.B.; DA GLÓRIA DE SOUZA, M.; CAVRIANI, G.; LIGEIRO-OLIVEIRA, A.P.; ALMEIDA, S.R.; TAVARES DE LIMA, W.; FARSKY, S.H.P. In vivo hydroquinone exposure inhibits leukocyte migration during an allergic lung inflammation in rats. Toxicol. Appl. Pharmacol., enviado para publicação.

MARTELIUS, T.; SALASPURO, V.; SALMI, M.; KROGERUS, L.; HOCKERSTEDT, K.; JALKANEN, S.; LAUTENSCHLAGER, I. Blockade of vascular adhesion protein-1 inhibits lymphocyte infiltration in rat liver allograft rejection. Am. J. Pathol., v.165, n.6, p.1993-2001, 2004.

MAYER, B.; PFEIFFER, S.; SCHRAMMEL, A.; KOESLING, D.; SCHMIDT, K.; BRUNNER, F. A new pathway of nitric oxide/cyclic GMP signaling involving Snitrosoglutathione. J. Biol. Chem., v.273, n.6, p.3264-3270, 1998.

MCCUE, J.M.; LINK, K.L.; EATON, S.S.; FREED, B.M. Exposure to cigarette tar inhibits ribonucleotide reductase and blocks lymphocyte proliferation. J. Immunol., v.165, n.12, p.6771-6775, 2000.

MCCUE, J.M.; LAZIS, S.; COHEN, J.J.; MODIANO, J.F.; FREED, B.M. Hydroquinone and catechol interfere with $T$ cell cycle entry and progression through the G1 phase. Mol. Immunol., v.39, n.16, p.995-1001, 2003.

MCCARTNEY-FRANCIS, N.; ALLEN, J.B.; MIZEL, D.E.; ALBINA, J.E.; XIE, Q.W.; NATHAN, C.F.; WAHL, S.M. Suppression of arthritis by an inhibitor of nitric oxide synthase. J. Exp. Med., v.178, n.2, p.749-754, 1993.

MCEWAN, I.J.; WRIGHT, A.P.; GUSTAFSSON, J.A. Mechanism of gene expression by the glucocorticoid receptor: role of protein-protein interactions. Bioessays, v.19, n.2, p.153-160, 1997. 
MELLO, S.B.; NOVAES, G.S.; LAURINDO, I.M.; MUSCARA, M.N.; MACIEL, F.M.; COSSERMELLI, W. Nitric oxide synthase inhibitor influences prostaglandin and interleukin-1 production in experimental arthritic joints. Inflamm. Res., v.46, n.2, p.72-77, 1997.

MERINEN, M.; IRJALA, H.; SALMI, M.; JAAKKOLA, I.; HANNINEN, A.; JALKANEN S. Vascular adhesion protein-1 is involved in both acute and chronic inflammation in the mouse. Am. J. Pathol., v.166 n.3, p.793-800, 2005.

METCHNIKOFF, E. La pathologic comparée de I'inflammation. Paris: Masson, 1893.

MICHELSON, A.D.; BARNARD, M.R.;HECHTMAN, H.B.; MACGREGOR, H.; CONNOLLY, R.J.; LOSCALZO, J.; VALERI, C.R. In vivo tracking of platelets: circulating degranulated platelets rapidly lose surface P-selectin but continue to circulate and function. Proc. Natl. Acad. Sci. USA, v.93, n.21, p.11877-11882, 1996.

MITCHELL, D.J.; YU, J.; TYM, L.K. Local L-NAME decreases blood flow and increases leukocyte adhesion via CD18. Am. J. Physiol., v.274, n.4 (pt.2), p.H1264-1268, 1998.

MONCADA, S.; HIGGS, E.A. Endogenous nitric oxide: physiology, pathology and clinical relevance. Eur. J. Clin. Invest., v.21, n.4, p.361-374, 1991.

MOORE, P.K.; AL-SWAYEK, O.A.; CHONG, N.W.S.; EVANS, R.A.; GIBSON, A. L-NG-nitro arginine (L-NOARG), a novel L-arginine reversible inhibitor of endothelium dependent vasodilation in vitro. Br. J. Pharmacol., v.99, p.408412, 1990. 
MORAES, F.R.; BECHARA, G.H.; MORAES, J.R. Effect of alloxan diabetes and adrenalectomy on carrageenin-induced pleurisy in the rat. Braz. J. Med. Biol. Res., v.20, n.1, p.47-53, 1987.

MORAN, J.L.; SIEGEL, D.; SUN, X.M.; ROSS, D. Induction of apoptosis by benzene metabolites in $\mathrm{HL} 60$ and $\mathrm{CD} 34+$ human bone marrow progenitor cells. Mol. Pharmacol., v.50,n.3, p.610-615, 1996.

MORAND, E.F.; LEECH, M. Hypothalamic-pituitary-adrenal axis regulation of inflammation in rheumatoid arthritis. Immunol. Cell. Biol., v.79, n.4, p.395-399, 2001.

MORI, Y.; KANAME, H.; SUMIDA, Y.; TANAKA, S.; KUBO, C.; TASHIRO, N.; NOMOTO, K. Changes in the leukocyte distribution and surface expression of adhesion molecules accompanied with hypothalamically induced restlessness in the cat. Neuroimmunomodulation, v.7, n.3, p.135-146, 2000.

MORIMOTO, K. Induction of sister delays in human lymphocytes by microsomal activation of benzene. Cancer Res., v.43, p.1330-1334, 1993.

MYHRE, O.; FONNUM, F. The effect of aliphatic, naphthenic, and aromatic hydrocarbons on production of reactive oxygen species and reactive nitrogen species in rat brain synaptosome fraction: the involvement of calcium, nitric oxide synthase, mitochondria, and phospholipase A. Biochem. Pharmacol., v.62, n.1, p.119-128, 2001.

MULLER, W.A..; RANDOLPH, G.J. Migration of leukocytes across endothelium and beyond: molecules involved in the transmigration and fate of monocytes. J. Leukoc. Biol., v.66, n.5, p.698-704, 1999. 
MUZYKA, V.; VEIMER, S.; SCHMIDT, N. On the carcinogenic risk evaluation of diesel exhaust: benzene airborne particles and alterations of heme metabolism in lymphocytes as markers of exposure. Sci. Total Environ., v.217n.1/2, p.103111, 1998.

NAVARRO-CID, J.; MAESO, R.; RODRIGO, E.; MUNOZ-GARCIA, R.; RUILOPE, L.M.; LAHERA, V.; CACHOFEIRO, V. Renal and vascular consequences of the chronic nitric oxide synthase inhibition. Effects of antihypertensive drugs. Am. J. Hypertens., v.9, n.11, p.1077-1083, 1996.

NIETERT, P.J.; SILVER, R.M. Systemic sclerosis: environmental and occupational risk factor. Curr. Opin. Rheumatol., v.12, n.6, p.520-526, 2000.

NIU, X.F.; SMITH, C.W.; KUBES, P. Intracellular oxidative stress induced by nitric oxide synthesis inhibition increases endothelial cell adhesion to neutrophils. Circ. Res., v.74, n.6, p.1133-1140, 1994.

NOVAES, G.S.; DE MELLO, S.B.; LAURINDO, I.M.; PALACIOS, F.A.; COSSERMELLI, W. Intra-articular nitric oxide levels in patients with rheumatoid arthritis. Rev. Hosp. Clin. Fac. Med. São Paulo, v.52, n.2, p.55-59, 1997.

ONG, C.N.; LEE, B.L. Determination of benzene and its metabolites: application in biological monitoring of environmental and occupational exposure to benzene. J. Chromatogr. B, v.660, p.1-22, 1994.

PALABRICA, T.; LOBB, R.; FURIE, B.C.; ARONOVITZ, M.; BENJAMÍN, C.; HSU, Y.M.; SAJER, S.A.; FURIE, B. Leukocyte accumulation promoting fibrin deposition is mediated in vivo by P-selectin on adherent platelets. Nature, v.359, n.6398, p.848-851, 1992. 
PALACIOS, F.A.; NOVAES, G.S.; GUZZO, M.L.; LAURINDO, I.M.; DE MELLO, S.B. Interrelationship of the kinin system, nitric oxide and eicosanoids in the antigen-induced arthritis in rabbits. Mediators Inflamm., v.8, n.4/5, p.245-251, 1999.

PEARSON, M.J.; LIPOWSKY, H.H. Influence of erythrocyte aggregation on leukocyte margination in postcapillary venules of rat mesentery. Am. J. Physiol. Heart Circ. Physiol., v.279, n.4, p.H1460-H1471, 2000.

PERRETTI, M.; BECHERUCCI, C.; SCAPIGLIATI, G.; PARENTE, L. The effect of adrenalectomy on interleukin-1 release in vitro and in vivo. $\mathrm{Br}$. J. Pharmacol., v.98, n.4, p.1137-1142, 1989.

PIPITONE, N.; SINHA, M.; THEODORIDIS, E.; GOULDING, N.; HALL, M.; LANCHBURY, J.; CORRIGALL, V.; PANAYI, G.; PITZALIS, C. The glucocorticoid inhibition of LFA-1 and CD2 expression by human mononuclear cells is reversed by IL-2, IL-7 and IL-15. Eur. J. Immunol., v.31, n.7, p.21352142, 2001.

PITZALIS, C.; PIPITONE, N.; PERRETTI, M. Regulation of leukocyteendothelial interactions by glucocorticoids. Ann. N. Y. Acad. Sci., v.966, p.108118, 2002.

PYATT, D.W.; STILLMAN, W.S.; IRONS, R.D. Hydroquinone, a reactive metabolite of benzene, inhibits NF Kappa B in primary human $\mathrm{CD}^{+} \mathrm{T}$ lymphocytes. Toxicol. Appl. Pharmacol., v.149, p.178-184, 1998.

PYATT, D.W.; YANG, Y.; STILLMAN, W.S.; CANO, L.L.; IRONS, R.D. Hydroquinone inhibits PMA-induced activation of NFkappa B in primary human CD19+ B lymphocytes. Cell. Biol. Toxicol., v.16, n.1, p.41-51, 2000. 
QUIROZ, Y.; PONS, H.; GORDON, K.L.; RINCON, J.; CHAVEZ, M.; PARRA, G.; HERRERA-ACOSTA, J.; GOMEZ-GARRE, D.; LARGO, R.; EGIDO, J.; JOHNSON, R.I.; RODRIGUEZ-ITURBE, B. Mycophenolate mofetil prevents salt-sensitive hypertension resulting from nitric oxide synthesis inhibition. Am. J. Physiol. Renal Physiol., v.281, n.1, p.F38-F47, 2001.

RAMPART, M. Neutrophil-endothelial cell interactions. In: BRAIN, S. D., ed. The handbook of immunopharmacology. immunopharmacology of microcirculation. San Diego: Academic Press, 1994. p.77-107.

RHEN, T.; CIDLOWSKI, J.A. Antiinflammatory action of glucocorticoids - new mechanisms for old drugs. N. Engl. J. Med., v.353, n.20, p.1711-1723, 2005.

REICHARDT, H.M.; SCHUTZ, G. Glucocorticoid signalling-multiple variations of a common theme. Mol. Cell. Endocrinol., v.146, n.1/2, p.1-6, 1998.

ROBINSON, S.N.; SHAH, R.; WONG, B.A.; WONG, V.A.; FARRIS, G.M. Immunotoxicological effects of benzene inhalation in male Sprague-Dawley rats. Toxicology, v.119, p.227-237, 1997.

ROSS, D. Functions and distribution of NQO1 in human bone marrow: potential clues to benzene toxicity. Chem. Biol. Interact., v.153-154, p.137-146, 2005.

ROSS, D.; SIEGEL, D.; SCHETTENBERG, D.G.; XIAOMING, M.S.; MORAN, J.L. Cell-specific activation and detoxification of benzene metabolites in mouse and human bone marrow: identification of target cells and a potential role of modulation of apoptosis in benzene toxicity. Environ. Health Perspect., v.104, p.1177-1182,1996.

ROSS, D.; KEPA, J.K.; WINSKI, S.L.; BEALL, H.D.; ANWAR, A.; SIEGEL, D. $\mathrm{NAD}(\mathrm{P}) \mathrm{H}$ : quinone oxidoreductase 1 (NQO1): chemoprotection, bioactivation, gene regulation and genetic polymorphisms. Chem. Biol. Interact., v.129, p.7797, 2000. 
ROOS, D.; LAW, S.K. Hematologically important mutations: leukocyte adhesion deficiency. Blood Cells Mol. Dis., v.27, p.1000-1004, 2001.

ROSsetTI, G.; COLLINGE, M.; BENDER, J.R.; MOLTENI, R.; PARDI, R. Integrin-dependent regulation of gene expression in leukocytes. Immunol. Rev., v.186, p.189-207, 2002.

ROTHMAN, N.; SMITH, T.H.; HAYES, R.B.; LI, G.L.; IRONS, R.D.; DOSEMECI, M.; HAA STILLMAN, W.S.; LINET, M.; XI, L.Q.; BECHTOLD, W.E.; WIEMELS, J.; CAMPLEMAN, S.; ZHANG, L.; QUINTANA, P.J.; TITENKO-HOLLAND, N.; WANG, Y.Z.; LU, W.; KOLACHAV MEYER, K.B.; YIN, S. An epidemiologic study of early biologic effects of benzene in Chinese workers. Environ. Health Pespect., v.104, n.6, p. 1365-1370, 1996.

SALE, R.; SABATINI, F.; SILVESTRI, M.; SERPERO, L.; PETECCHIA, L.; ROSSI, G.A. Concentration-dependent activity of mometasone furoate and dexamethasone on blood eosinophils isolated from atopic children: modulation of Mac-1 expression and chemotaxis. Int. Immunopharmacol., v. 4, n.13, p.1687-1696, 2004.

SALMI, M.; JALKANEN, S. VAP-1: an adhesin and an enzyme. Trends Immunol., v.22, n.4, p.211-216, 2001.

SANZ, M.J.; HICKEY, M.J.; JOHNSTON, B.; MCCAFFERTY, D.M.; RAHARJO, E.; HUANG, P.L.; KUBES P. Neuronal nitric oxide synthase (NOS) regulates leukocyte-endothelial cell interactions in endothelial NOS deficient mice. Br. J. Pharmacol., v.134, n.2, p.305-312, 2001.

SCHAAF, M.J.; CIDLOWSKI, J.A. Molecular determinants of glucocorticoid receptor mobility in living cells: the importance of ligand affinity. Mol. Cell. Biol., v.23, n.6, p.1922-1934, 2003. 
SCHAD, H.; SCHAFER, F.; WEBER, L.; SEIDEL, H.J. Determination of benzene metabolites in urine of mice by solid -phase extraction and highperformance liquid chromatografy. J. Chromatogr., v.593, p.147-151,1992.

SCHENKER, M.B.; JACOBS, J.A. Respiratory effects of organic solvents exposure. Tuber. Lung Dis., v.77, n.1, p.4-18, 1996.

SCHMID, D.; BURMESTER, G.R.; TRIPMACHER, R.; KUHNKE, A.; BUTTGEREIT, F. Bioenergetics of human peripheral blood mononuclear cell metabolism in quiescent, activated, and glucocorticoid-treated states. Biosci. Rep., v.20, n.4, p.289-302, 2000.

SCHMID-SCHONBEIN, G.W.; USAMI, S.; SKALAK, R.; CHIEN, S. The interaction of leukocytes and erythrocytes in capillary and postcapillary vessels. Microvasc. Res., v.19, p.45-70, 1980.

SEATON, M.J.; SCHLOSSER, P.M.; BOND, J.A.; MEDINSKY, M.A. Benzene metabolism human liver microsomes in relation to cytochrome P450 2E1 activity. Carcinogenesis, v.15, p.1799-1806, 1994.

SECCO, D.D.; PARON, J.A.; DE OLIVEIRA, S.H.; FERREIRA, S.H.; SILVA, J.S.; CUNHA, F.Q. Neutrophil migration in inflammation: nitric oxide inhibits rolling, adhesion and induces apoptosis. Nitric Oxide, v.9, n.3, p.153-164, 2003.

SMALLEY, D.M.; LEY, K. L-selectin: mechanisms and physiological significance of ectodomain cleavage. J. Cell. Mol. Med., v.9, n.2, p.255-266, 2005.

SMOAK, K.A.; CIDLOWSKI, J.A. Mechanisms of glucocorticoid receptor signaling during inflammation. Mech. Ageing Dev., v.125, n.10/11, p.697-706, 2004. 
SPRINGER, T.A. The LFA-1, Mac-1 glycoprotein family and its deficiency in an inherited disease. Fed. Proc., v.44, n.10, 2660-2663, 1985.

SNYDER, C.A.; GOLDSTEIN, B.D.; SELLAKUMAR, A.R.; BROMBERG, I.; LASKIN, S.; ALBERT, R.E. The inhalation toxicology of benzene: incidence of hematopoietic neoplasmas and hematoxicity in AKR/J and C57BL/6J mice. Toxicol. Appl. Pharmacol., v.54, p.323-331, 1980.

SNYDER, R. Xenobiotic metabolism and the mechanism(s) of benzene toxicity. Drug Metab. Rev., v.36, n.3/4, p.531-547, 2004.

STEFANOVIC-RACIC, M.; MEYERS, K.; MESCHTER, C.; COFFEY, J.W.; HOFFMAN, R.A.; EVANS, C.H. N-monomethyl arginine, an inhibitor of nitric oxide synthase, suppresses the development of adjuvant arthritis in rats. Arthritis Rheum., v.37, n.7, p.1062-1069, 1994.

STENBERG, V.I.; BOULEY, M.G.; KATZ, B.M.; LEE, K.J.; PARMAR, S.S. Negative endocrine control system for inflammation in rats. Agents Actions, v.29, n.3/4, p.189-195, 1990.

STENBERG, P.E.; MCEVER, R.P.; SHUMAN, M.A.; JACQUES, Y.V.; BAINTON, D.F. A platelet alpha-granule membrane protein (GMP-140) is expressed on the plasma membrane after activation. J. Cell. Biol., v.101, n.3, p880-886, 1985.

STOLEN, C.M.; MARTTILA-ICHIHARA, F.; KOSKINEN, K.; YEGUTKIN, G.G.; TURJA, R.; BONO, P.; SKURNIK, M.; HANNINEN, A.; JALKANEN, S.; SALMI, $\mathrm{M}$. Absence of the endothelial oxidase $\mathrm{AOC} 3$ leads to abnormal leukocyte traffic in vivo. Immunity, v.22, n.1, p.105-115, 2005.

STELLATO, C. Post-transcriptional and nongenomic effects of glucocorticoids.

Proc. Am. Thorac. Soc., v.1, n.3, p.255-263, 2004. 
STUEHR, D.J. Mammalian nitric oxide synthases. Biochim. Biophys. Acta, v.1411, n.2/3), p.217-230, 1999.

SUBRAMANIAM, M.; KOEDAM, J.A.; WAGNER, D.D. Divergent fates of Pand E-selectins after their expression on the plasma membrane. Mol. Biol. Cell,.v.4, n.8, p.791-801, 1993.

SUN, C.; MIGLIORINI, C.; MUNN, L. Red Blood cells initiate leukocyte rolling in postcapillary expansions: a lattice Boltzmann analysis. Biophys. J., v.85, p.208-222, 2003.

SZEKANECZ, Z.; KOCH, A.E. Therapeutic inhibition of leukocyte recruitment in inflammatory diseases. Curr. Opin. Pharmacol., v.4, n.4, p.423-428, 2004.

TAYLOR, M.E.; DRICKAMER, K. Structural requirements for high affinity binding of complex ligands by the macrophage mannose receptor. J. Biol. Chem., v.268, n.1, p.399-404, 1993.

TEDDER, T.F.; STEEBER, D.A.; CHEN, A.; ENGEL, P. The selectins: vascular adhesion molecules. FASEB J., v.9, n.10, p.866-873, 1995.

THOMAS, D.J.; SADLER, A.; SUBRAHMANYAM, V.; SIEGEL, D.; REASOR, M.J.; WIERDA, D.; ROSS, D. Bone marrow stromal cell bioactivation and detoxification of the benzene metabolite hydroquinone: comparison of macrophages of fibrobastoids cells. Mol. Pharmacol., v.37, p.255-262, 1990.

TILDERS, F.J.; DERIJK, R.H.; VAN DAM, A.M.; VINCENT, V.A.; SCHOTANUS, K.; PERSOONS, J.H. Activation of the hypothalamus-pituitary-adrenal axis by bacterial endotoxins: routes and intermediate signals. Psychoneuroendocrinology, v.19, n.2, p.209-232, 1994. 
TORSTEINSDOTTIR, I.; ARVIDSON, N.G.; HALLGREN, R.; HAKANSSON, L. Enhanced expression of integrins and CD66b on peripheral blood neutrophils and eosinophils in patients with rheumatoid arthritis, and the effect of glucocorticoids. Scand. J. Immunol., v. 50, n.4, p.433-439, 1999.

TUO, J.; DENG, X.; LOFT, S.; POULSEN, H.E. Dexamethasone ameliorates oxidative DNA damage induced by benzene and LPS in mouse bone marrow. Free Radic. Biol. Med., v.30, n.1, p.29-36, 1999.

TUO, J.; LOFT, S.; POULSEN, H.E. Enhanced benzene-induced DNA damage in PMA-stimulated cell in vitro and in LPS-treated animals. Free Radic. Biol. Med., v.26, n.7/8, p.801-808, 1999a.

VAN EEDEN, S.F.; BICKNELL, S.; WALKER, B.A.; HOGG, J.C. Polymorphonuclear leukocytes L-selectin expression decreases as they age in circulation. Am. J. Physiol., v.272, n.1 (pt.2), p.H401-H408, 1997.

VELASCO-LEZAMA, R.; BARRERA ESCORCIA, E.; MUNOZ TORRES, A.; TAPIA AGUILA GONZALEZ RAMIRES, C.; GARCIA LORENZANA, M.; ORTIZ MONROY, V.; BRTANCOU RULE, M. A model for induction of aplastic anemia by subcutaneous administration of benzene in mice. Toxicology, v.162, n.3, p.179-191, 2001.

VENTURI, G.M.; TU, L.; KADONO, T.; KHAN, A.I.; FUJIMOTO, Y.; OSHEL, P.; BOCK, C.B.; MILLER, A.S.; ALBRECHT, R.M.; KUBES, P.; STEEBER, D.A.; TEDDER, T.F. Leukocyte migration is regulated by L-selectin endoproteolytic release. Immunity, v.19, n.5, p. 713-24, 2003.

VERFAILLIE, C.M. Adhesion receptors as regulators of the hematopoietic process. Blood, v.92, n.8, p.2609-2612, 1998. 
VERÍSSIMO DE MELLO, S.B.; GUZZO, M.L.; LISBOA, L.F.S.; FARSKY, S.H.P. Pharmacological characterization of arthritis induced by Bothrops jararaca venom in rabbits. A positive cross-talk between bradykinin, nitric oxide and Prostaglandin E2 (BjV). Mediat. Inflamm., v 11, n. 1,13-16, 2002.

VESTWEBER, D.; BLANKS, J.E. Mechanisms that regulate the function of the selectins and their ligands. Physiol. Rev., v.79, n.1, p.181-213, 1999.

WAIDYNATHA, S.; ROTHMAN, N.; LI, G.; SMITH, M.T.; YIN, S.; RAPPAPORT, S.M. Rapid determination of six metabolites in occupationally exposed and unexposed subjects. Anal. Biochem., v.327, p.184-199, 2004.

WALLER, A. Microscopic examination of some principal tissues of the animal frame as observed in the tongue of the living frog, toad, etc. Lond. Edin. Dubl. Phil. Mag., v.29, p.271-287, 1846.

WEBER, P.S.; MADSEN, S.A.; SMITH, G.W.; IRELAND, J.J.; BURTON, J.L. Pre-translational regulation of neutrophil L-selectin in glucocorticoid-challenged cattle. Vet. Immunol. Immunopat., v.83, n.3/4, p.213-240, 2001.

WEBER, P.S.; TOELBOELL, T.; CHANG, L.C.; TIRRELL, J.D.; SAAMA, P.M.; SMITH, G.W.; BURTON, J.L. Mechanisms of glucocorticoid-induced downregulation of neutrophil L-selectin in cattle: evidence for effects at the geneexpression level and primarily on blood neutrophils. J. Leukoc. Biol., v.75, p.815-827, 2004.

WIERDA, D.; IRONS, R.D. Hydroquinone and catechol reduce the frequency of progenitor B lymphocytes in mouse spleen and bone marrow. Immunopharmacology, v.4, n.1, p. 41-54, 1982. 
WILD, M.K.; LUHN, K.; MARQUARDT, T.; VESTWEBER, D. Leukocyte adhesion deficiency II: therapy and genetic defect. Cells Tissues Organs, v.172, p.161-173, 2002.

WINN, R.; VEDDER, N.; RAMAMOORTHY, C.; SHARAR, S.; HARLAN, J. Endothelial and leukocyte adhesion molecules in inflammation and disease. Blood Coagul. Fibrinolysi., v.9, suppl.2, p.S17-S23, 1998.

WISSINK, S.; VAN HEERDE, E.C.; VAND DER BURG, B.; VAN DER SAAG, P.T. A dual mechanism mediates repression of NF-kappaB activity by glucocorticoids. Mol. Endocrinol., v.12, n.3, p.355-363, 1998.

WOO, L.W.; JOHNSON, T.J.; GARDNER, D.C. Inhibitory effects of benzene metabolites on nuclear DNA synthesis in bone marrow cells. J. Toxicol. Environ. Health, v.26, p.277-291, 1989.

WU, T.; YUAN, Y.; WU, Y.; HE, H.; ZHANG, G.; TANGUAY, R.M. Presence of antibodies to heat shock proteins in workers exposed to benzene and patients with benzene poisoning. Cell Stress Chapeerones, v.3, n.3, p.161-167, 1998.

YEGUTKIN, G.G.; SALMINEN, T.; KOSKINEN, K.; KURTIS, C.; MCPHERSON, M.J.; JALKANEN, S.; SALMI, M. A peptide inhibitor of vascular adhesion protein-1 (VAP-1) blocks leukocyte-endothelium interactions under shear stress. Eur. J. Immunol., v.34, n.8, p.2276-2285, 2004.

YOON, B.I.; HIRABAYASHI, Y.; KAWASAKI, Y.; KODAMA, Y.; KANETO, T.; KIM, D.Y.; INOUE, T. Mechanism of action of benzene toxicity: cell cycle suppression in hemopoietic progenitor cells (CFU-GM). Exp. Hematol., v.29, n.3, p.278-285, 2001. 
YOON, B.-L.I.; HIRABAYASHI, Y.; KAWASAKI, Y.; KODAMA, Y.; KANEKO, T.; KANNO, J.; KIM, D.Y.; KURIYAMA-FUJII, Y.; INOUE, T. Aryl hydrcarbon receptor mediates benzene-induced hematotoxicity. Toxicol. Scienc., v.70, p.150-156, 2002.

ZAMPOLLI, A.; BASTA, G.; LAZZERINI, G.; FEELISCH, M.; DE CATERINA, R. Inhibition of endothelial cell activation by nitric oxide donors. J. Pharmacol. Exp. Ther., v.295, n.2, p.818-823, 2000.

ZHAO, L.; SHEY, M.; FARNSWORTH, M.; DAILEY, M.O. Regulation of membrane metalloproteolytic cleavage of L-selectin (CD62I) by the epidermal growth factor domain. J. Biol. Chem., v.276, n.33, p.30631-30640, 2001. 


\section{ANEXOS}

Pág.

Anexo 1. Trabalho apresentado: FARSKY, S.H.P.; SANNOMIYA, P.; GARCIALEME, J. Secreted glucocorticoids regulate leukocyte-endothelial interactions in inflammation: A direct vital microscopic study. Journal of Leukocyte Biology,57:37986,1995

Anexo 2. Trabalho apresentado: FARSKY, S.H.P.; SANNOMIYA, P.; GARCIALEME, J. CAVALCANTI, D.M.H.; LOTUFO, C.M.C.; BORELLI, P.; MARKUS, R.P.; FARSKY, S.H.P. Adrenal deficiency alters mechanisms of neutrophil mobilization. Molecular and Cellular Endocrinology, 2006.

Anexo 3. Trabalho apresentado: FARSKY, S.H.P.; SANNOMIYA, P.; GARCIALEME, J. CAVALCANTI, D.M.H.; LOTUFO, C.M.C.; BORELLI, GUZZO, M.L.; FARSKY, S.H.P.; DE NUCCI, G.; ANTUNES, E.; SILVA, M.A.G. VERÍSSIMO DE MELLO, S.B. Role of kinins and nitric oxide on the rabbit arthrits induced by Bothrops jararaca venom. Toxicon, 38(11):1535-46, 2000.

Anexo 4. Trabalho apresentado: VERÍSSIMO DE MELLO, S.B.; GUZZO, M.L.; LISBOA, L.F.S.; FARSKY, S.H.P. Pharmacological characterization of arthritis induced by Bothrops jararaca venom in rabbits. A positive cross-talk between bradykinin, nitric oxide and Prostaglandin E2 (BjV). Mediators of Inflammation 11 (1):13-6, 2002.

Anexo 5. Trabalho apresentado: FARSKY, S.H.P.; BORELLI, P.; FOCK, R.A.; PROTO, S.Z.; FERREIRA, J.M.C.; MELLO, S.B.V. Chronic blockage of nitric oxide biosynthesis in rats: effect on leukocyte endothelial interaction and on leukocyte recruitment. Inflammation Research, 53:442-542, 2004.

Anexo 6. Trabalho apresentado: LOURENÇO, E.L.B.; FERREIRA, A.; PINTO, E.; YONAMINE, M.; FARSKY, S.H.P. On-Fiber derivatization of SPME extracts of Phenol, Hydroquinone and Catechol with GC-MS detection. Chromatographia, 2006.

Anexo 7. Trabalho apresentado: MACEDO, S.M.; LOURENÇO, E.L.; BORELLI, P.; FOCK, R.A.; FERREIRA, J.M. Jr; FARSKY, S.H.P. Effect of in vivo phenol or hydroquinone exposure on events related to neutrophil delivery during an inflammatory response. Toxicology, 2006.

Anexo 8. Trabalho apresentado: MACEDO, S.M.D; VAZ, S.C.M.; LOURENÇO, E.L.B.; DA GLÓRIA DE SOUZA, M.; CAVRIANI, G.; LIGEIRO-OLIVEIRA, A.P.; ALMEIDA, S.R.; TAVARES DE LIMA, W.; FARSKY, S.H.P. In vivo hydroquinone exposure inhibits leukocyte migration during an allergic lung inflammation in rats. Toxicology and Applied Pharmacology, enviado para publicação. 


\title{
Secreted glucocorticoids regulate leukocyte-endothelial interactions in inflammation. A direct vital microscopic study
}

\author{
Sandra P. Farsky, Paulina Sannomiya, and J. Garcia-Leme \\ Department of Pharmacology, Institute of Biomedical Sciences, University of São Paulo, São Paulo, SP, Brazil
}

\begin{abstract}
Leukocytes come into intimate contact with the venular endothelium as they extravasate from blood to the interstitium during inflammation. In exteriorized tissues, the number of leukocytes rolling along the vessel wall was markedly increased in adrenalectomized and metyrapone-treated animals, relative to sham-operated and normal animals. During the development of an acute, local inflammatory response, rollers were numerically decreased and a stronger adhesion of the cells to the endothelium, with a concomitant migration into tissues, was observed. Adhesion and migration were much more marked in adrenalectomized and metyrapone-treated animals than in controls, suggesting that secreted glucocorticoids exert a suppressive effect on leukocyte-endothelial interactions. The increased number of rolling leukocytes in adrenalectomized and metyrapone-treated animals apparently resulted in more cells available to migrate into inflamed tissues. The effect appears to involve receptor occupancy and induction of gene expression because normal animals receiving the steroid antagonist RU 38486 , actinomycin D, or cycloheximide behaved as adrenalectomized or metyrapone-treated animals. Administration to adrenalectomized animals of a monoclonal antibody to the membrane glycoprotein complex CD18 did not affect the number of rolling cells, but dramatically reduced the number of adherent or migrated leukocytes. It is suggested that secreted glucocorticoids, in addition to an effect on rolling behavior of circulating leukocytes, might also modulate the activity of the glycoprotein complex CD18 on white blood cells. The ultimate consequence is a restrictive effect on cell emigration in inflammation. J. Leukoc. Biol. 57: $379-386 ; 1995$.
\end{abstract}

Key Words: adhesion molecules $\cdot C D 11 / C D 18 \cdot$ microcirculation $\cdot R U 38486$

\section{INTRODUCTION}

The principal cellular events that constitute the phenomena of inflammation have been clearly described in studies employing direct observation of microvessels. These studies indicate that leukocytes always become adherent to the vascular endothelium before penetrating the vessel wall and accumulating at sites of injury. It is now established that specific adhesion glycoproteins expressed on the surface of leukocytes and endothelial cells play a relevant role in the adhesion phenomenon [1-9]. Agents capable of interfering with leukocyte-endothelial interactions may, therefore, exhibit antiinflammatory properties.

Administration of glucocorticoids results in a suppressive action on neutrophil mobilization during inflammation. Because locomotion of leukocytes remains unaffected after exposure of the cells to glucocorticoids [10], the steroids, at least in part, appear to inhibit leukocyte accumulation in an inflamed area by blocking the production of mediators, particularly cytokines, involved in the recruitment process [11-13]. More recent findings support the view that glucocorticoids are also likely to directly inhibit the expression of adhesive molecules by stimulated endothelium [8, 14]

Blood levels of glucocorticoids are consistently and markedly increased during the development of inflammation [15-19]. The steroids, secreted in larger amounts at the early stages of an inflammatory reaction, are thought to regulate the initiation and subsequent course of inflammatory responses [17, 20,21].

These observations prompted us to investigate the influence of endogenous glucocorticoids on cellular events occurring in inflammation. The data to be presented suggest that glucocorticoids, through receptor-mediated genomic actions, modulate leukocyte-endothelial interactions and, consequently, leukocyte accumulation in an injured area.

\section{MATERIALS AND METHODS}

\section{Animals}

Male Wistar rats weighing between 200 and $220 \mathrm{~g}$ at the beginning of the experiments were used. The animals were allowed a standard pellet diet and tap water ad libitum throughout the experimental period. Blood glucose concentrations, hematocrit values, plasma corticosterone levels, and total and differential blood leukocyte counts were determined in the different experimental groups. Blood glucose levels were evaluated with a blood glucose monitor in samples obtained from the cut tip of the tail of nonanesthetized animals. The hematocrit was determined at the moment of death in blood samples collected from the abdominal aorta while the animals were under anesthesia. Corticosterone levels were estimated by radioimmunoassay [22]. Total and differential leukocyte counts were carried out in blood samples obtained from the cut tip of the tail. Total counts were made in Neubauer chambers. Stained blood films were used for differential leukocyte counts.

\section{Direct vital microscopy of the microcirculation}

The animals were anesthetized with pentobarbital sodium $(40 \mathrm{mg} / \mathrm{kg}$, intraperitoneally) and the internal spermatic fascia of the wall of the scrotal chamber was exteriorized for microscopic examination in situ [23]. This was done through

Abbreviations: HBSS, Hanks' balanced salt solution; LPS, lipopolysac charide; $\mathrm{mAb}$, monoclonal antibody.

Reprint requests: J. Garcia-Leme, Department of Pharmacology, Institute of Biomedical Sciences, University of São Paulo, São Paulo, SP, Brazil, 05508-900.

Received July 28, 1994; accepted October 18, 1994 
a longitudinal incision of the skin and dartos muscle in the midline over the ventral aspect of the scrotum and opening of the cremaster muscle to expose the internal fascia. The procedure does not require extensive surgical manipulation for the observation of the vascular network, and provides a valuable means for transilluminating a tissue for quantitative studies of the microcirculation. The animals were maintained on a special board thermostatically controlled at $37^{\circ} \mathrm{C}$, which included a transparent platform on which the tissue to be transilluminated was placed. The preparation was kept moist and warmed by irrigating the tissue with warmed $\left(37^{\circ} \mathrm{C}\right)$ Ringer-Locke's solution, $\mathrm{pH} 7.2-7.4$, containing $1 \%$ gelatin. The composition of the solution was $(\mathrm{mM}): \mathrm{NaCl} 154, \mathrm{KCl} 5.6, \mathrm{CaCl}_{2} \cdot 2 \mathrm{H}_{2} \mathrm{O} 2, \mathrm{NaHCO}_{3} 6$, and glucose 5. The rate of outflow of the solution onto the exposed tissue was controlled to maintain the preparation in continuous contact with a film of the liquid. A 500-line television camera was incorporated to a triocular Zeiss microcupe to facilitate observation of the enlarged image $(\times 3400)$ on the video screen. Images were recorded on a video recorder using a $\times 40$ longitudinal distance objective with a 0.65 numerial aperture. An image-splitting micrometer was adjusted to the phototube of the microscope [24]. The image-splitter sheared the optical image into two separate images and displaced one with respect to the other. By rotating the image-splitter in the phototube the shearing was maintained in a direction at right angles to the axis of the vessel. The displacement of one image from the other allowed measurement of the vessel diameter. Vessels selected for study were third-order venules, defined according to their branch order location within the microvascular network [ 25 , 26 . These vessels corresponded to postcapillary venules; their diameters ranged from 12 to $16 \mu \mathrm{m}$.

Interaction of leukocytes with the luminal surface of the venular endothelium was studied in a $100 \mu \mathrm{m}$ segment of the vessels using recorded images. Leukocytes moving in the periphery of the axial stream, in contact with the endothelium, were considered to be rollers $[27,28]$, and their number was determined in 10 -min periods. These leukocytes moved sufficiently slowly to be individually visible and were counted as they rolled past a selected point on one side of the vessel. The number of leukocytes adhering to the endothelium (stickers) was determined at the same intervals on the vascular segment. A given section of the vascular bed was tested only once, and no more than two determinations were performed on a single animal. These were averaged for each animal. The number of leukocytes accumulating at the connective tissue adjacent to a postcapillary venule was determined in a standard area of $1,000 \mu \mathrm{m}^{2}$. This area was defined on the video screen, $10 \mu \mathrm{m}$ in tissue corresponding to $3.4 \mathrm{~cm}$ on the screen (magnification $\times 3400$ ). Five different fields were evaluated on a single animal to avoid variability based upon sampling. Data were then averaged for each animal. A local inflammatory response was evoked by the injection of $0.1 \mathrm{ml}$ of a solution containing $500 \mu \mathrm{g} / \mathrm{ml}$ carrageenan in physiologic saline into the scrotal chamber of the animals.

\section{Erythrocyte velocity measurement in microvessels}

Erythrocyte velocity was measured in postcapillary venules by the time delay between the photometric signals that originate from two windows positioned along the centerline of the televised vessel under study [29].

\section{Neutrophil migratory assays in vitro}

The migratory assays were performed using a multiwel chemotaxis chamber. In brief, aliquots of cell suspensions containing $1.5 \times 10^{6}$ neutrophils were added to the upper compartment of the chamber separated from the chemotac tic agent in the lower compartment by a cellulose nitrate filter, $8 \mu \mathrm{m}$ average pore size. Hanks' balanced salt solution (HBSS) was substituted for the chemotactic agent to measure random migration [30]. The cells were incubated in humidified air for $60 \mathrm{~min}$, followed by removal of the filters for fixation and staining of the cells. Neutrophil migration within the filter was determined under light microscopy by the leading front method, in which the distance was measured from the top of the filter to the farthest plane still containing two cells with a $\times 40$ objective [30]. For each variable, duplicate wells were always run. Five fields were counted and averaged for each filter. Neutrophils were obtained after the intraperitoneal injection of $20 \mathrm{ml}$ of $1 \%$ oyster glycogen (type II, Sigma, St. Louis, MO) in phosphate-buffered saline. The animals were anesthetized with ether and the cells collected by rinsing the abdominal cavity with $\mathrm{HBSS}$ containing $1 \mathrm{U} / \mathrm{ml}$ heparin. Cell viability was confirmed by the trypan blue exclusion method. Final cell suspensions contained $0.1 \%$ crystalline bovine albumin To induce the generation of chemotactic activity, lipopolysaccharide (LPS, serotype 026:B6, Sigma) from Escherichia coli was incubated in rat plasma $(65 \mu \mathrm{g} / \mathrm{ml})$ for $30 \mathrm{~min}$ at $37^{\circ} \mathrm{C}$. Varying concentrations of LPS-activated plasma were obtained with dilution in HBSS

\section{Surgical procedures}

Bilateral adrenalectomy was performed with entrance into the peritoneal cavity through bilateral skin and muscle incisions [31]. Adrenalectomized rats were supplied with physiological saline in addition to water. In the set of shamoperated animals, surgical incisions, handling of the abdominal viscera, and closure of the incisions were of similar extent as those of actual surgeries. No special postoperative care was required in this case. Surgeries were performed under ether anesthesia; the animals used 6 days postoperatively. Intact controls were kept under the same conditions as operated rats.

\section{Pharmacological treatments}

Metyrapone (Ciba-Geigy, São Paulo, Brazil) dissolved in physiological saline was administered to block synthesis of glucocorticoids without causing a typical deficiency of mineralocorticoids [32]. Two daily doses of $30 \mathrm{mg} / \mathrm{kg}$ each were given orally at 12 -h intervals for 6 days. Animals were used $2 \mathrm{~h}$ after the last dose of the drug. Dexamethasone (Merck, Sharp \& Dohme, São Paulo, Brazil) was given intraperitoneally to adrenalectomized rats 6 days postoperatively. A single dose of $1 \mathrm{mg} / \mathrm{kg}$ was used and the animals tested $3 \mathrm{~h}$ later. To investigate the mechanisms by which endogenous glucocorticoids influence leukocyte-endothelial interactions and cell migration, animals were treated with the steroid antagonist RU 38486 (Roussel UCLAF, Romainville, France), with actinomycin D (Sigma), cycloheximide (Sigma), or with a monoclonal antibody ( $\mathrm{mAb}$ ) against the membrane glycoprotein complex CD18 (Immunotech, Marseille. France, clone BL5). The steroid antagonist RU 38 486, dissolved in absolute ethanol, was administered by the intraperitoneal route and the animals tested $2 \mathrm{~h}$ later. Actinomycin D and clycloheximide, dissolved in physiological saline. were given intraperitoneally $2 \mathrm{~h}$ before testing. The antiCD18 mAb, dissolved in physiological saline, was given intravenously $30 \mathrm{~min}$ or $2 \mathrm{~h}$ before testing. In all cases, controls received the same volume of the vehicle used to dissolve the drugs, by the same route. 
Anexo 1. Trabalho apresentado: FARSKY, S.H.P.; SANNOMIYA, P.; GARCIA-LEME, J.

TABLE 1. Blood Glucose Concentrations, Hematocrit Values, and Corticosterone Levels in Different Treatment Groups

\begin{tabular}{|c|c|c|c|}
\hline Treatment group ${ }^{a}$ & $\begin{array}{l}\text { Blood glucose } \\
\text { (mg/dl) }\end{array}$ & $\begin{array}{l}\text { Hematocrit } \\
(\%)\end{array}$ & $\begin{array}{l}\text { Corticosterone } \\
(\mathrm{ng} / \mathrm{ml})\end{array}$ \\
\hline Normal & $98 \pm 2.0(38)$ & $47.5 \pm 0.6(12)$ & $61.6 \pm 5.0 \quad(10)$ \\
\hline Sham-operated & $98 \pm 2.3(34)$ & $48.2 \pm 0.8(13)$ & $52.1 \pm 7.0$ \\
\hline Adrenalectomized & $94 \pm 1.3(35)$ & $51.0 \pm 0.7(13)$ & $0.08 \pm 0.02(10)^{\circ}$ \\
\hline Metyrapone-treated & $96 \pm 2.1(21)$ & $47.8 \pm 0.8(13)$ & $1.63 \pm 0.42(6)^{\circ}$ \\
\hline
\end{tabular}

${ }^{a}$ A nimals submitted to surgical procedures were used 6 days postoperatively. Metyrapone was given as two daily doses of $30 \mathrm{mg} / \mathrm{kg}$ each at $12-\mathrm{h}$ intervals for 6 days and the animals were used $2 \mathrm{~h}$ after the last dose.

${ }^{*} P<0.001$ vs values in normal and sham-operated groups. Figures within parentheses indicate number of animals used.

\section{Data analysis}

Means and standard errors of means (SEM) of all data are presented and were compared by Student's $t$-test or analysis of variance with significant probability levels of less than 0.01 .

\section{RESULTS}

To investigate the influence of endogenous glucocorticoids on leukocyte-endothelial interactions, we used adrenalectomy, and administration of metyrapone, which blocks synthesis of glucocorticoids without causing a typical deficiency of mineralocorticoids. The procedures did not cause significant changes in blood glucose concentrations or hematocrit values in comparison with values determined in sham-operated and normal animals. Plasma corticosterone levels, however, were sharply reduced by adrenalectomy or treatment with metyrapone (Table 1 ).

\section{Leukocyte-endothelial interactions}

Slow-rolling leukocytes and firmly adhered blood cells are absent in most normal tissues. However, rollers can be observed in surgically prepared tissues for investigation of the microcirculation such as the exteriorized internal spermatic fascia. In the absence of an inflammatory stimulus, adherence of leukocytes to the vessel wall or migration of cells into tissues did not occur. Nevertheless, leukocytes could be seen rolling along the endothelium with a velocity much lower than that of plasma. The phenomenon was particularly prominent in postcapillary venules. Quantitation of the rolling cell flux in the different groups of animals showed that previous adrenalectomy or administration of metyrapone resulted in a marked increase in the number of rolling leukocytes, relative to sham-operated or normal animals. Treatment of adrenalectomized animals with dexamethasone $3 \mathrm{~h}$ before testing, caused a full recovery of cell behavior to match control values. Results are presented in Figure 1. The observed changes were not dependent on the number of circulating leukocytes or blood flow: 1) total and differential counts in the peripheral blood were equivalent in normal, sham-operated, adrenalectomized, and metyrapone-treated animals (Table 2) and 2) erythrocyte velocity determined in adrenalectomized and sham-operated rats was not significantly different from that of controls. Values obtained ranged from $1.80 \pm 0.13 \mathrm{~mm} / \mathrm{s}$ to $2.11 \pm 0.63 \mathrm{~mm} / \mathrm{s}$, indicating comparable blood flow rates in the different experimental groups.

Tests performed $2 \mathrm{~h}$ after the injection of an irritant (carrageenan dissolved in physiological saline) into the scrotum to induce a local inflammatory response, showed a reduction in the number of rolling leukocytes. The levels attained were equivalent in all groups studied. Since the tissue cannot be exposed for such an interval without damage, the determination of levels of rolling leukocytes before the initiation of the inflammatory stimulus is impractical under this condition. For comparison, see data in Figure 1. The decrease in rolling was paralleled by the observation of cells adhering to the vessel wall and accumulation of leukocytes in perivascular tissues. Adherence was particularly noticeable in adrenalectomized and metyrapone-treated rats, in which much of the endothelial surface of randomly chosen venules was covered by firmly adhered cells. Similarly, accumulation of leukocytes in a standard area $\left(1,000 \mu \mathrm{m}^{2}\right)$ of the connective tissue adjacent to the observed postcapillary venule was more intense in these groups of animals than in controls (Fig. 2).

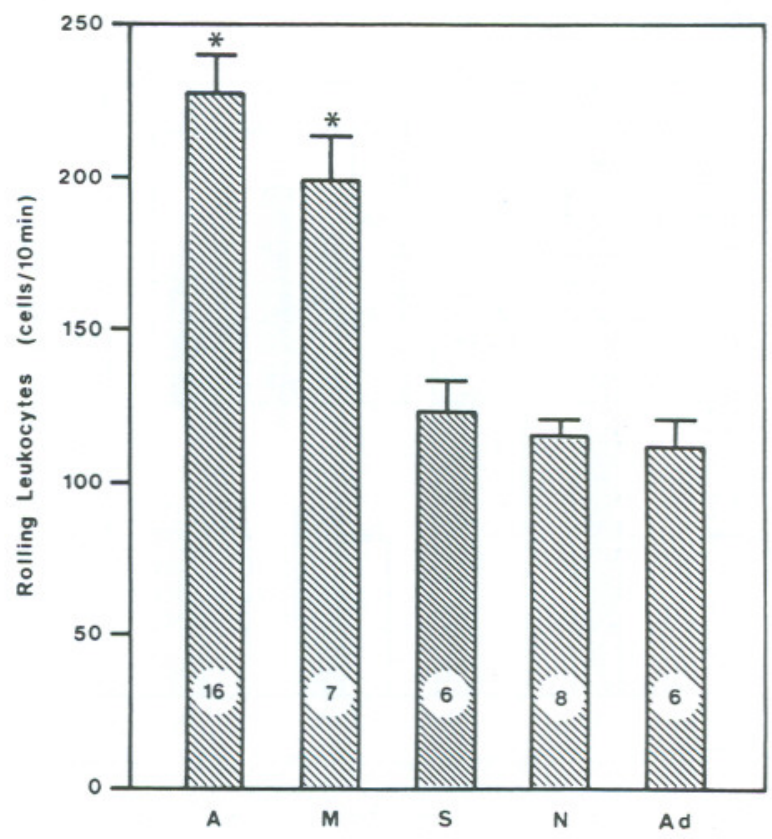

Fig. 1. Rolling leukocytes in postcapillary venules of adrenalectomized (A), metyrapone-treated $(M)$, sham-operated $(S)$, adrenalectomized given dexamethasone (Ad), and normal $(\mathrm{N})$ rats. Animals submitted to surgical procedures were used 6 days postoperatively. Metyrapone was given as two daily doses of $30 \mathrm{mg} / \mathrm{kg}$ each at 12 -h intervals for 6 days and the animals were used $2 \mathrm{~h}$ after the last dose. Dexamethasone was given as a single dose $(1 \mathrm{mg} / \mathrm{kg})$ 6 days after adrenalectomy and the animals used $3 \mathrm{~h}$ later. Figures within bars indicate number of animals in each group. ${ }^{*} P<0.001$ vs. values in other groups. 
Anexo 1. Trabalho apresentado: FARSKY, S.H.P.; SANNOMIYA, P.; GARCIA-LEME, J.

Secreted glucocorticoids regulate leukocyte-endothelial interactions in inflammation: A direct vital microscopic study. Journal of Leukocyte Biology,57:379-86, 1995.

TABLE 2. Leukocyte Counts in the Peripheral Blood of Different Treatment Groups

\begin{tabular}{|c|c|c|c|c|c|}
\hline \multirow[b]{2}{*}{ Treatment group ${ }^{a}$} & \multicolumn{5}{|c|}{ Cells $/ \mathrm{mm}^{3}$} \\
\hline & Total & Lymphocytes & Monocytes & Neutrophils & Eosinophils \\
\hline Normal (8) & $13,237 \pm 507$ & $8,364 \pm 384$ & $1,752 \pm 172$ & $3,038 \pm 231$ & $83 \pm 32$ \\
\hline Sham-operated (6) & $13,151 \pm 612$ & $8,408 \pm 317$ & $1,319 \pm 129$ & $3,335 \pm 241$ & $89 \pm 26$ \\
\hline Adrenalectomized (9) & $12,383 \pm 485$ & $7,903 \pm 491$ & $1,477 \pm 140$ & $2,816 \pm 224$ & $187 \pm 38$ \\
\hline Metvrapone-treated (7) & $12,699+610$ & $8,089 \pm 464$ & $1,779 \pm 144$ & $2,696 \pm 197$ & $135 \pm 54$ \\
\hline
\end{tabular}

${ }^{\circ}$ Animals submitted to surgical procedures were used 6 days postoperatively. Metyrapone was given as two daily doses of $30 \mathrm{mg} / \mathrm{kg}$ each at $12-\mathrm{h}$ inter vals for 6 days and the animals were used $2 \mathrm{~h}$ after the last dose. Figures within parentheses indicate number of animals in each group.

Essential changes, capable of altering cell locomotion, did not occur in adrenalectomized animals. Cells collected from normal and sham-operated rats, as well as from adrenalectomized rats were tested in vitro for their capacity to respond to varying concentrations of LPS-activated normal plasma, using the micropore filter system. Equivalent responses were obtained with either cell population. Migration ranged from $59+2 \mu \mathrm{m}$ to $68 \pm 3 \mu \mathrm{m}$ at a $1 \%$ concentration of activated plasma and from $100 \pm 3 \mu \mathrm{m}$ to $108 \pm 2 \mu \mathrm{m}$ at a $10 \% \mathrm{con}-$ centration, when the different cell populations were compared. Similarly, the capacity to generate chemotactic factors upon interaction with LPS was comparable in plasma samples obtained from adrenalectomized, sham-operated, and normal animals. This was assessed by quantitating the response of normal cells in the presence of varying concentrations (1 and 10\%) of LPS-activated plasma obtained from either group of animals. Migration ranged from $61 \pm 7 \mu \mathrm{m}$ to $70 \pm 10 \mu \mathrm{m}$ and from $104 \pm 2 \mu \mathrm{m}$ to $114 \pm 2 \mu \mathrm{m}$ at each concentration of activated plasma, when the different plasma samples were compared.

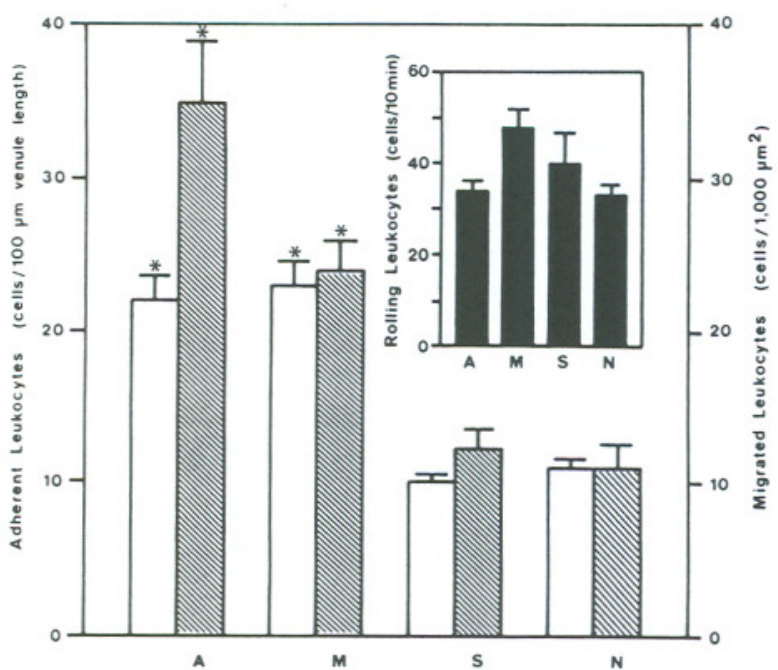

Fig. 2. Cells sticking to the endothelium of a $100-\mu \mathrm{m}$ segment of postcapillary venules (open bars), accumulation of leukocytes in a standard area $\left(1000 \mu \mathrm{m}^{2}\right)$ of the perivascular tissue (hatched bars), and rolling leukocytes (inset) in adrenalectomized (A), metyrapone-treated (M), sham-operated $(\mathrm{S})$, and normal $(\mathrm{N})$ rats. Results were obtained $2 \mathrm{~h}$ after the initiation of a local inflammatory response induced by the injection of carrageenan. For comparison, values for rolling leukocytes in animals not treated with carrageenan are indicated in Fig. 1. Animals submitted to surgical procedures were used 6 days postoperatively. Metyrapone was given as two daily doses of $30 \mathrm{mg} / \mathrm{kg}$ each at $12-\mathrm{h}$ intervals for 6 days and the animals were used $2 \mathrm{~h}$ after the last dose. Five animals were used in each group. ${ }^{*} P<0.001$ vs. corresponding values in other groups. No significant difference was observed between values for rolling leukocytes.

\section{Effect of RU 38486}

The steroid antagonist RU 38486 was administered intraperitoneally to normal rats $2 \mathrm{~h}$ before testing. Treatment resulted in a dose-dependent increase in the number of rolling leukocytes whereas no alteration was observed in controls receiving the vehicle alone (Fig. 3). The values attained

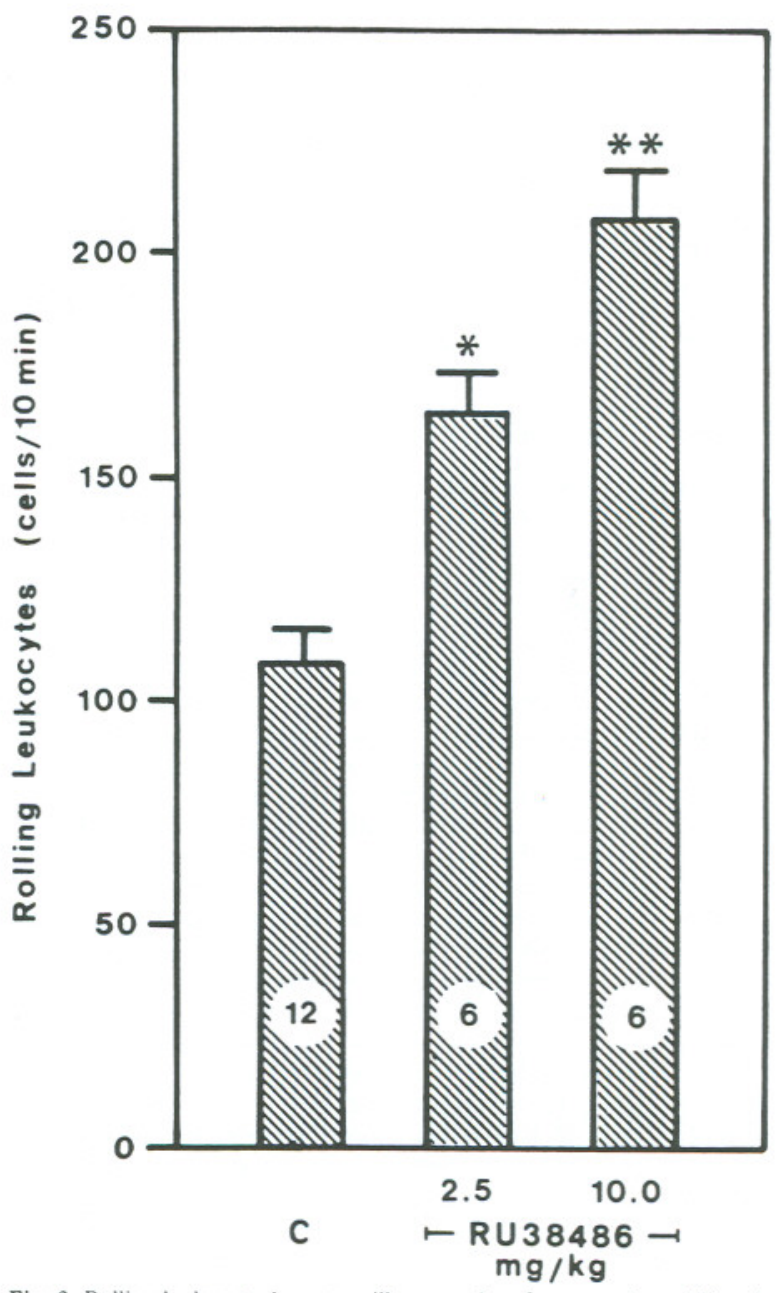

Fig. 3. Rolling leukocytes in postcapillary venules of untreated rats (C) and rats receiving the glucocorticoid antagonist RU 38486 . The antagonist was administered intraperitoneally as a single injection $2 \mathrm{~h}$ before testing Figures within bars indicate number of animals in each group. ${ }^{*} P<0.01$ and $\cdots P<0.001$ vs. value in control group. 
matched those observed in adrenalectomized and metyraponetreated animals. Total and differential leukocyte counts performed before and $2 \mathrm{~h}$ after drug administration showed no changes in the number of circulating leukocytes (data not shown).

During the development of a local inflammatory response evoked by carrageenan as referred to above, RU 38486 given immediately before the irritant caused a marked enhancement in the number of adherent and migrated cells. Rolling leukocytes were concomitantly reduced as compared with data presented in Figure 3. Normal animals receiving the steroid antagonist behaved strictly as adrenalectomized or metyrapone-treated rats. Results are presented in Figure 4.

\section{Effect of actinomycin D and cycloheximide}

Actinomycin D, which blocks the transcription of DNA by RNA polymerase, and cycloheximide, which inhibits protein synthesis, were given intraperitoneally to normal animals $2 \mathrm{~h}$ before testing. The doses were $1 \mathrm{mg} / \mathrm{kg}$ and $2 \mathrm{mg} / \mathrm{kg}$, respectively. Treatment with both drugs resulted in a significant increase in the number of rolling leukocytes $(P<$ 0.001 ) in comparison with values in control groups. The levels attained matched those observed in adrenalectomized and metyrapone-treated animals. The number of rolling leukocytes in actinomycin D-treated rats were $237 \pm 5, n=5$ versus $120 \pm 10, n=5$ in control animals. In cycloheximidetreated rats and matching controls the number of rolling leukocytes were $224 \pm 7, n=6$ and $110 \pm 7, n=6$, respectively. Total and differential leukocyte counts were not al-

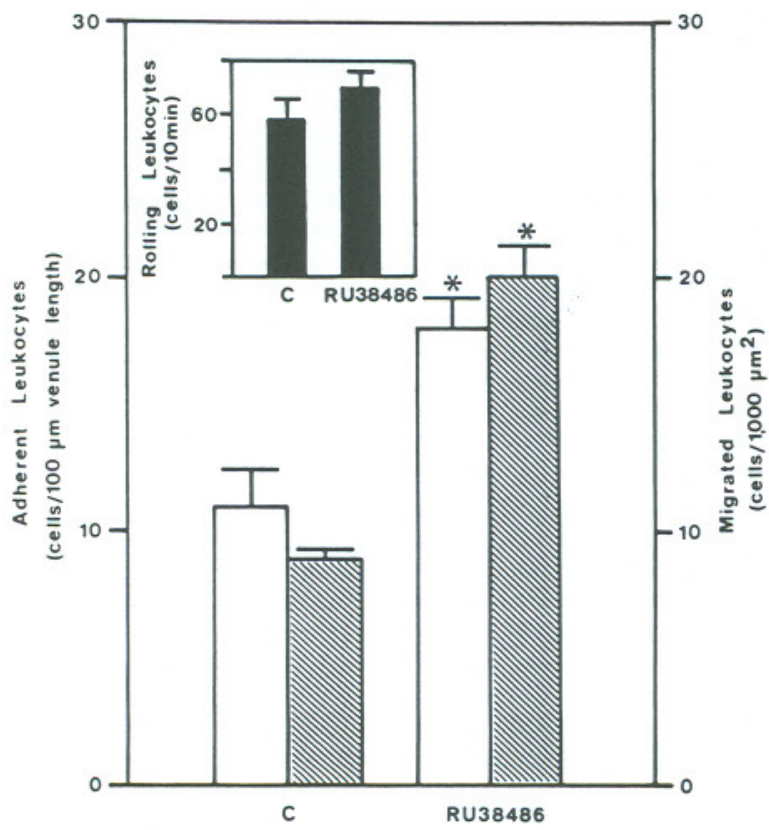

Fig. 4. Cells sticking to the endothelium of a $100-\mu \mathrm{m}$ segment of postcapillary venules (open bars), accumulation of leukocytes in a standard area $\left(1000 \mu \mathrm{m}^{2}\right)$ of the perivascular tissue (hatched bars), and rolling leukocytes (inset) in untreated normal rats (C) and rats receiving $10 \mathrm{mg} / \mathrm{kg}$ of the glucocorticoid antagonist RU 38486 . Results were obtained $2 \mathrm{~h}$ after the initiation of a local inflammatory response induced by injection of carrageenan. The steroid antagonist was administered intraperitoneally as a single injection, immediately before the injection of carrageenan. Five animals were used in each group. ${ }^{*} P<0.01$ vs. corresponding values in control group

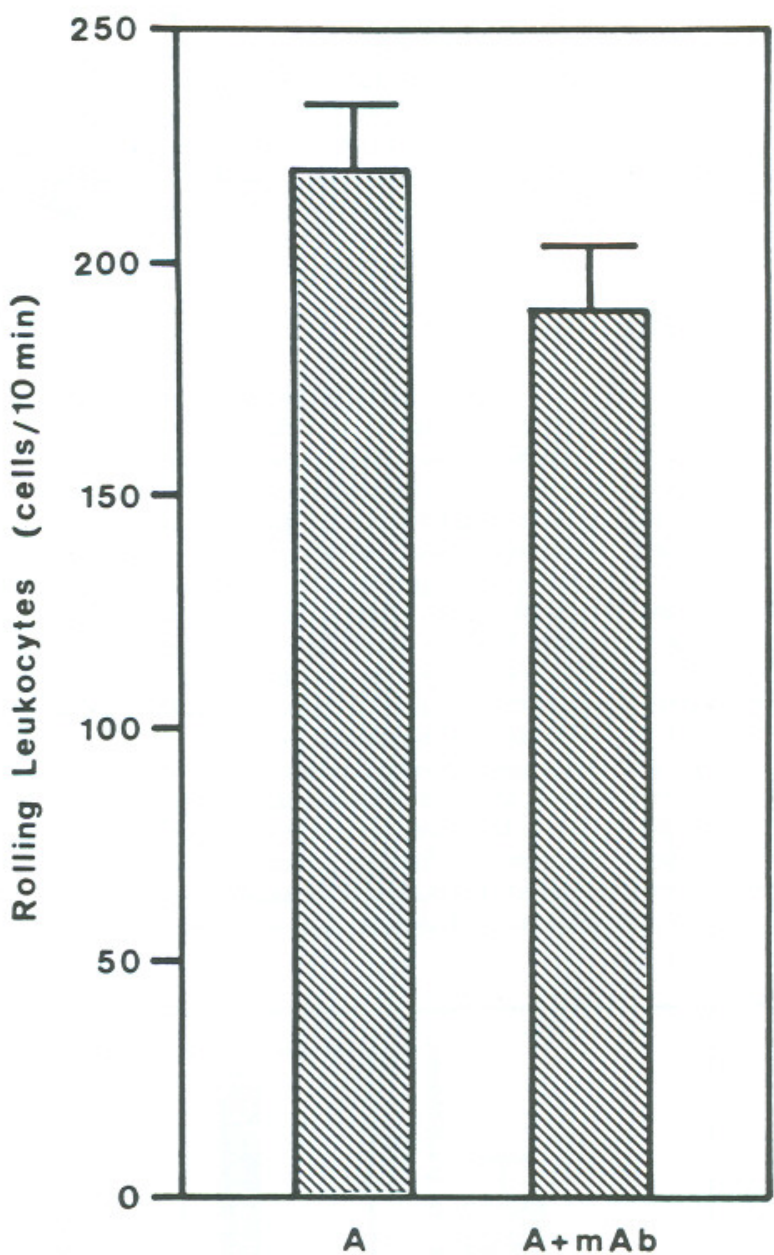

Fig. 5. Rolling leukocytes in postcapillary venules of untreated adrenalectomized rats $(\mathrm{A})$ and adrenalectomized rats receiving $1 \mathrm{mg} / \mathrm{kg}$ anti-CD18 $\mathrm{mAb}(\mathrm{A}+\mathrm{mAb})$ intravenously. Results were obtained $30 \mathrm{~min}$ after the injection of the anti-CD18 mAb. Five animals were used in each group.

tered by treatment of the animals with the drugs (data not shown).

During the development of a local inflammatory response evoked by carrageenan as referred to above, actinomycin D and cycloheximide given immediately before the irritant caused an enhancement in the number of migrated cells to a standard area in the perivascular tissue. Values were $18 \pm 1.2, n=5$ and $19 \pm 0.9, n=6$ cells $/ 1,000 \mu \mathrm{m}^{2}$ in actinomycin D- and cycloheximide-treated animals, respectively. In matching controls, values were $8 \pm 0.6, n=5$ and $9 \pm 0.7, n=6$, respectively $(P<0.01$ by comparing values in treated and untreated animals).

Effect of a monoclonal antibody against the membrane glycoprotein complex CD18

A commercially available anti-CD18 mAb was given in travenously to adrenalectomized animals $30 \mathrm{~min}$ before testing. Untreated (adrenalectomized) controls received the same volume of the vehicle used to dissolve the mAb. Treatment did not influence the number of rolling leukocytes (Fig. 5), which is increased in these animals as shown above. 
During the development of a carrageenan-induced local inflammatory response the number of rolling leukocytes remained high in adrenalectomized animals receiving the antiCD18 mAb immediately before the injection of the irritant. However, a dramatic decrease in the number of leukocytes adhering to the endothelium and in the number of cells accumulating at the interstitial tissue was observed. Data are presented in Figure 6.

\section{DISCUSSION}

Exteriorization of a tissue for the investigation of the microcirculation or its exposure to inflammatory stimul causes marked changes in the behavior of leukocytes at the microcirculatory level. In the former circumstance cells rolling along the venular endothelium of the microcirculation network are observed. This early type of leukocyteendothelial interaction is a prerequisite for stronger adhesion. During the development of an inflammatory response, leukocytes eventually become adherent to the venular en dothelium and then extravasate to the perivascular tissue.

We show here that the number of leukocytes rolling along the venular endothelium was markedly increased in adrenalectomized and metyrapone-treated animals relative to shamoperated and normal animals. Plasma corticosterone levels were sharply reduced by adrenalectomy or treatment with metyrapone. Metyrapone, through inhibition of the $11 \beta$. hydroxylation reactions, markedly decreases the secretion of cortisol, corticosterone, and aldosterone, while the secretion

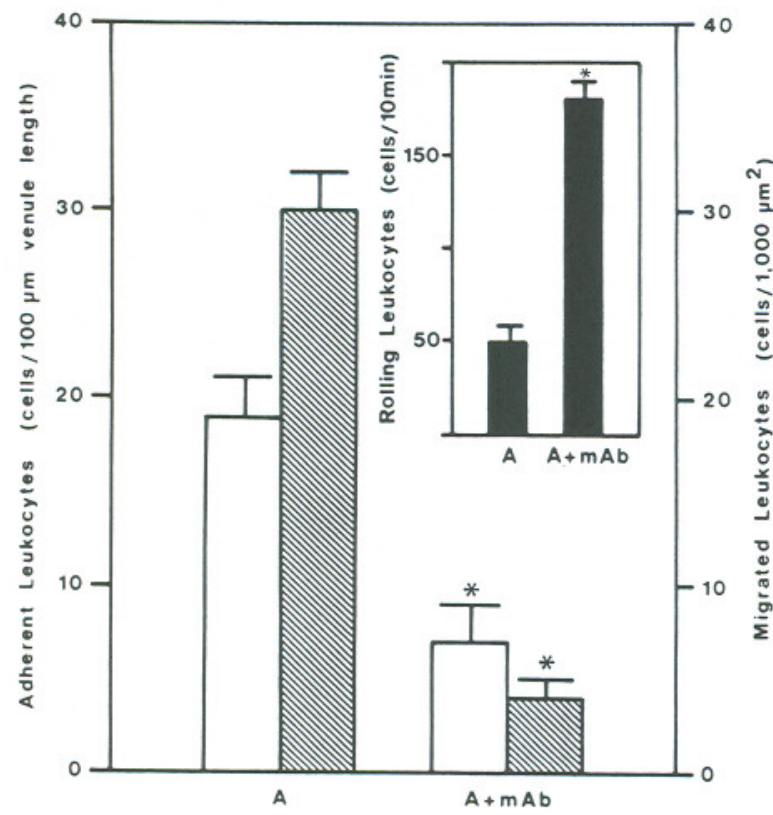

Fig. 6. Cells sticking to the endothelium of a $100-\mu \mathrm{m}$ segment of postcapil lary venules (open bars), accumulation of leukocytes in a standard are $\left(1000 \mu \mathrm{m}^{2}\right)$ of the perivascular tissue (hatched bars), and rolling leukocytes (inset) in adrenalectomized rats (A) and adrenalectomized rats receiving $1 \mathrm{mg} / \mathrm{kg}$ anti CD18 $\mathrm{mAb}(\mathrm{A}+\mathrm{mAb})$. Results were obtained $2 \mathrm{~h}$ after the initiation of a local inflammatory response induced by the injection of car. rageenan. The $\mathrm{mAb}$ was administered intravenously as a single injection, immediately before the injection of carrageenan. Four animals were used in each group. $\cdot P<0.001$ vs. corresponding values in adrenalectomized each group
animals. of 11-deoxycorticosteroids is relatively unimpaired. Accord ingly, the administration of metyrapone results in a compensatory increase in the secretion of adrenocorticotropic hormone and in enhanced secretion of 11-deoxycortisol, a relatively inert steroid, and 11-deoxycorticosterone, a mineralocorticoid. Therefore, the drug blocks the production of glucocorticoids but does not typically cause a deficiency of mineralocorticoids [32]. The relative lack of glucocorticoids in adrenalectomized and metyrapone-treated animals appears to be the major determinant for the increased number of rollers in these animals. Total and differential leukocyte counts in the peripheral blood were equivalent in all groups tested. Comparable blood flow rates, as assessed by erythrocyte velocity measurements, were observed in adrenalectomized, sham-operated, and normal animals. Furthermore, adrenalectomy followed by treatment with dexamethasone caused a full recovery of cell behavior to match control values.

Two $h$ after the initiation of a local inflammatory process induced by the injection of carrageenan, the number of rollers at the microcirculation network was reduced to comparable levels in all groups of animals. This was accompanied by the appearance of cells adhering to the vessel wall and accumulation of leukocytes in perivascular tissues. An inverse relationship between adhesion and rolling is demonstrated, indicating that when a greater number of stationary white blood cells prevails a reduction in the number of rolling leukocytes is observed $[28,33]$. The adhesion phenomenon was particularly prominent in adrenalectomized and metyrapone-treated animals, in which much of the endothelial surface was covered by firmly adhered cells. Similarly, accumulation of leukocytes in a standard area of the connective tissue adjacent to the venule was more intense in adrenalectomized and metyrapone-treated animals. Leukocytes collected from adrenalectomized or normal animals, however, exhibited comparable chemotactic responses in a concentration gradient of LPS-activated plasma. In addition, the capacity to generate chemotactic factors upon interaction with LPS was equivalent in plasma samples obtained from adrenalectomized and normal animals. Accordingly, adrenalectomy does not influence cell locomotion per se. Secreted glucocorticoids, therefore, appear to exert a suppressive effect on leukocyte-endothelial interactions.

The effect apparently involves receptor occupancy and induction of gene expression. Normal animals receiving the steroid antagonist RU 38486 behaved as adrenalectomized or metyrapone-treated animals. A dose-dependent increase in the number of rolling leukocytes was observed in animals given the antagonist. Furthermore, RU 38486 caused a marked enhancement in the number of adherent and migrated cells during the development of a local inflammatory response. RU 38486 stabilizes the association of steroid receptors with heat shock protein 90 in the presence of ligand, thereby preventing translocation of glucocorticoid receptors to the nucleus and transcription of genes containing glucocorticoid-responsive elements [34-38]. The finding was corroborated by experiments in which actinomycin D, which blocks the transcription of DNA by RNA polymerase, and cycloheximide, an inhibitor of protein synthesis, were used. Both drugs, given to normal animals, markedly enhanced the number of rolling leukocytes. In addition, the drugs increased the amount of cells migrating into the interstitial tissue during the development of an inflammatory reaction.

Therefore, acting at their cellular receptors, glucocorticoids influenced leukocyte rolling along the venular endothelium and leukocyte adhesion to vessel wall. The in - 
creased number of rolling leukocytes in adrenalectomized and metyrapone-treated animals apparently resulted in more cells available to respond to chemoattractants and therefore in more migration into inflamed tissues. Glycoproteins of the $\beta 2$-integrin family, collectively termed CD11/CD18 complex [39, 40], are known to be required for the firm adhesion of rolling cells to the endothelium $[4,8,9$, 41-43]. Administration of an anti-CD18 monoclonal antibody to adrenalectomized animals caused a marked reduction in the number of cells adhering to the endothelial surface of postcapillary venules and an almost complete block of leukocyte migration to the perivascular inflamed tissue without affecting the number of rolling leukocytes. Members of the selectin family of cell adhesion molecules are thought to mediate leukocyte rolling along the walls of the microvasculature [1, 43-46]. Recent observations demonstrate that glucocorticoids, at nanomolar concentrations, inhibit the expression of interactive molecules by endothelial cells that either act as counter-receptors for CD11/CD18 complex or recognize molecular constituents in leukocyte glycolipids and glycoproteins $[8,14]$. Accordingly, secreted glucocorticoids, in addition to an effect on rolling behavior of circulating leukocytes possibly involving molecules of the selectin family, might also modulate the activity of the CD11/CD18 complex on white blood cells.

\section{ACKNOWLEDGMENTS}

The authors wish to thank the Institute Roussel UCLAF, Romainville, France, for a generous supply of the glucocorticoid antagonist RU 38486 and Irene M. Gouveia, Maria L. Pereira, and Maria A. Oliveira for expert technical help. This work was supported in part by FAPESP grants and a fellowship awarded to S.P.F.

\section{REFERENCES}

1. Arfors, K.E., Lundberg, C., Kindbom, L., Lundberg, K., Beatty, P.G., Harlan, J.M. (1987) A monoclonal antibody to the membrane glycoprotein complex CD18 inhibits polymorphonuclear leukocyte accumulation and plasma leakage in vivo. Blood 69, 338-340.

2. Tonnesen, M.G. (1989) Neutrophil-endothelial cell interactions: mechanisms of neutrophil adherence to vascular endothelium. J. Invest. Dermatol. 93 (Suppl.), 53-58.

3. Vadas, M.A., Gamble, J.R. (1990) Regulation of the adhesion neutrophils to endothelium. Biochem. Pharmacol. 40, 1683-1687.

4. Albelda, S.M., Buck, C.A. (1990) Integrins and other cell adhesion molecules. FASEB J. 4, 2868-2880.

5. Nourshargh, S., Williams, T.J. (1990) Neutrophil-endothelial cell interactions in vivo. In The Endothelium: An Introduction to Current Research (J.B. Warren, ed), John Wiley \& Sons, New York, 171-186

6. Pober, J.S., Cotran, R.S. (1991) What can be learned from the expression of endothelial adhesion molecules in tissues? Lab. Invest. 64, 301-305.

7. Argenbright, L.W., Letts, L.G., Rothlein, R. (1991) Monoclonal antibodies to the leukocyte membrane CD18 glycoprotein complex and to intercellular adhesion molecule-1 inhibit leukocyteendothelial adhesion in rabbits. J. Leukoc. Biol. 49, 253-257.

8. Cronstein, B.N., Weissmann, G. (1993) The adhesion molecules of inflammation. Arthritis Rheum. 36, 147-157.

9. Rampart, M. (1994) Neutrophil-endothelial cell interactions. In Immunopharmacology of the Microcirculation (S.D. Brain, ed), Academic Press, San Diego, 77-107

10. Schleimer, R.P., Freeland, H.S., Peters, S.P., Brown, K.E., Derse, C.P. (1989) An assessment of the effects of glucocorti- coids on degranulation, chemotaxis, binding to vascular en dothelium and formation of leukotriene $\mathrm{B}_{4}$ by purified human neutrophils. J. Pharmacol. Exp. Ther. 250, 598-605.

11 Knudsen, PJ., Dinarello, C.A., Strom, T.B. (1987) Glucocorticoids inhibit transcriptional and post-transcriptional expression of interleukin 1 in U937 cells. J. Immunol. 139, 4129-4134

12. Bochner, B.S., Rutledge, B.K., Schleimer, R.P. (1987) Interleukin 1 production by human lung tissue. II. Inhibition by antiinflammatory steroids. J. Immunol. 139, 2303-2307.

13. Dinarello, C.A., Endres, S. (1989) Role of interleukin-1 in the pathogenesis of hypertensive diseases. J. Cell. Biochem. 39, 229-238.

14. Cronstein, B.N., Kimmel, S.C., Levin, R.I., Martiniuk, F. Weissmann, G. (1992) A mechanism for the antiinflammatory effects of corticosteroids: the glucocorticoid receptor regulates leukocyte adhesion to endothelial cells and expression of endothelial-leukocyte-adhesion molecule-1 and intercellular adhesion molecule-1. Proc. Natl. Acad. Sci. USA 89, 9991-9995.

15. Melby, J., Egdahl, R., Spink, W. (1960) Secretion and metabolism of cortisol after injection of endotoxin. J. Lab. Clin. Med. 56, 50-62.

16. Moberg, G.P. (1971) Site of action of endotoxins on hypothalamic-pituitary-adrenal axis. Am. J. Physiol. 220, 397-400.

17. Garcia-Leme, J., Schapoval, E.E.S. (1975) Stimulation of the hypothalamo-pituitary-adrenal axis by compounds formed in inflamed tissue. Br. J. Pharmacol. 53, 75-83.

18. Moraes, F.R., Garcia-Leme, J. (1982) Endogenous corticosteroids and insulin in acute inflammation. Microvasc. Res. 23, 281-293.

19. Stenberg, V.I., Bouley, M.G., Katz, B.M., Lee, K.J., Parmar, S.S. (1990) Negative endocrine control system for inflammation in rats. Agents Actions 29, 189-195.

20. Sternberg, E.M., Hill, J.M., Chrousos, G.P., Kamilaris, T., Listwak, S.J., Gold, P.W., Wilder, R.L. (1989) Inflammatory mediator-induced hypothalamic-pituitary-adrenal axis activation is defective in streptococcal cell wall arthritis-susceptible Lewis rats. Proc. Natl. Acad. Sci. USA 86, 2374-2378.

21. Garcia-Leme, J., Farsky, S.P. (1993) Hormonal control of inflammatory responses. Mediat. Inflamm. 2, 181-198.

22. Abraham, G.E. (1974) Radioimmunoassay of steroids in biological materials. Acta Endocrinol. 75 (Suppl. 183), 5-42.

23. Fortes, Z.B., Farsky, S.P., Oliveira, M.A., Garcia-Leme, J (1991) Direct vital microscopic study of defective leukocyteendothelial interactions in diabetes mellitus. Diabetes 40 , $1267-1273$.

24. Baez, S.A. (1973) A method for in-line measurement of lumen and wall of microscopic vessels in vivo. Microvasc. Res. 5, 229-308

25. Gore, R.W., Bohlen, H.G. (1977) Microvascular pressures in rat intestinal muscle and mucosal villi. Am. J. Physiol. 233, H685-693.

26. Rhodin, J.A.G. (1980) Architecture of the vessel wall. In Handbook of Physiology. The Cardivascular System. Sect. 2, vol II (D.F. Bohr, A.P. Somlyo and H.V. Sparks, eds) American Physiological Society, Bethesda, MD, 1-31.

27. Atherton, A., Born, G.V.R. (1972) Quantitative investigations of the adhesiveness of circulating polymorphonuclear leukocytes to blood vessel walls. J. Physiol. 222, 447-474.

28. Dahlen, S.E., Bjork, J., Hedqvist, P., Arfors, K.E., Hammarstrom, S., Lindgren, J.A., Samuelsson, B. (1981) Leukotrienes promote plasma leakage and leukocyte adhesion in postcapillary venules: in vivo effects with relevance to the acute inflammatory response. Proc. Natl. Acad. Sci. USA 78, 3887-3891.

29. Intaglietta, M., Silverman, N.R., Tompkins, W.R. (1975) Capillary flow velocity measurements in vivo and in situ by television methods. Microvasc. Res. 10, 165-179.

30. Zigmond, S.H., Hirsch, J.G. (1973) Leukocyte locomotion and chemotaxis. New methods for evaluation and demonstration of a cell-derived chemotactic factor. J. Exp. Med. 137, 387-410.

31. Waynforth, H.B. (1980) Experimental and Surgical Technique in the Rat. Academic Press, New York, 124-126.

32. Temple, E.T., Liddle, G.W. (1970) Inhibitors of adrenal steroid biosynthesis. Annu. Rev. Pharmacol. Toxicol. 10, 199-215.

33. Firrel, J.C., Lipowsky, H.H. (1989) Leukocyte margination and 
deformation in mesenteric venules of rat. Am. J. Physiol. 256, $\mathrm{H} 1667-\mathrm{H} 1674$

34. Groyer, A., Schweizer-Groyer, G., Cadepont, F., Mariller, M. Baulieu, E.E. (1987) Antiglucocorticosteroid effects suggest why steroid hormone is required for receptors to bind DNA in vivo but not in vitro. Nature (London) 328, 624-626.

35. Yang Yen, H.F., Chambard, J.C., Sun, Y.L., Smeal, T. Schmidt, T.J., Drouin, J., Karin, M. (1990) Transcriptional in terference between c-Jun and the glucocorticoid receptor: mutual inhibition of DNA binding due to direct protein-protein interactions. Cell 62, 1205-1215.

36. Schüle, R., Rangarajan, P., Kliewer, S., Ransone, L.J., Bolado, J., Yang, N., Verma, I.M., Evans, R.M. (1990) Functional antagonism between oncoproteins c-jun and the glucocorticoid receptor. Cell $62,1217-1226$.

37. Picard, D., Khursheed, B., Garabedian, M.J., Fortin, M.G. Lindquist, S., Yamamoto, K.R. (1990) Reduced levels of hsp90 compromise steroid receptor action in vivo. Nature (London) 348 , 166-168.

38. Evans, R.M. (1988) The steroid and thyroid hormone recepto superfamily. Nature (London) 240, 889-895.

39. Hynes, R.O. (1987) Integrins: A family of cell surface receptors.
Cell 48, 549-554

40. Arnout, M.A. (1990) Structure and function of the leukocyte adhesion molecules CD11/CD18. Blood 75, 1037-1050.

41. Hogg, N. (1989) The leukocyte integrins. Immunol. Today 10, $111-114$

42. Bevilacqua, M.P. (1993) Endothelial-leukocyte adhesion molecules. Annu. Rev. Immunol. 11, 767-804

43. Granger, D.N., Kubes, P. (1994) The microcirculation and inflammation: modulation of leukocyte-endothelial cell adhesion. J. Leukoc. Biol. 55, 662-675.

44. Von Andrian, U.H., Chambers, J.D., McEvoy, L.M., Bargatze, R.F., Arfors, K.E., Butcher, E.C. (1991) Two-step model of leukocyte-endothelial cell interaction in inflammation: distinct roles for LECAM-1 and the leukocyte beta 2 integrins in vivo. Proc. Natl. Acad. Sci. USA 81, 7538-7542.

45. Ley, K., Gaehtgens, P., Fennie, C., Singer, M.S., Lasky, L.A., Rosen, S.D. (1991) Lectin-like cell adhesion molecule-1 mediates leukocyte rolling in mesenteric venules in vivo. Blood 77 , 2553-2555.

46. Lawrence, M.B., Springer, T.A. (1991) Leukocytes roll on a selectin at physiologic flow rates: distinction from and prerequisite for adhesion through integrins. Cell 65, 859-873. 
+ Model

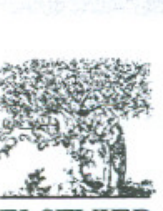

ELSEVIER

\title{
Adrenal deficiency alters mechanisms of neutrophil mobilization
}

\author{
Danielle M.H. Cavalcanti ${ }^{a}$, Celina M.C. Lotufo ${ }^{b}$, Primavera Borelli ${ }^{a}$, Agostinho L.M. Pereira ${ }^{\text {c }}$, \\ Ana Marisa C. Tavassi ${ }^{\mathrm{c}}$, Regina P. Markus ${ }^{\mathrm{b}}$, Sandra H.P. Farsky ${ }^{\mathrm{a}, *}$ \\ ${ }^{a}$ Department of Clinical and Toxicological Analyses, School of Pharmaceutical Sciences. University of São Paulo, \\ Av. Prof. Lineu Prestes 580 Bl. 13 B. São Paulo, SP, 05503-900. Brazil \\ ${ }^{\mathrm{b}}$ Department of Physiology, Bioscience Institute, University of São Paulo. Brazil \\ ' Biochemistry Laboratory, Butantan Institute, Brazil \\ Received 5 August 2005; received in revised form 13 December 2005; accepted 18 January 2006
}

\begin{abstract}
Deficiency of adrenal hormones promotes exacerbated neutrophil influx into inflammatory sites. We investigated the effect of adrenal deficiency on neutrophil mobilization comparing adrenalectomized (ADX) male Wistar rats to sham-operated (SO) or non-manipulated (N) animals, as controls . Seven days after surgeries, the number of neutrophils in peripheral blood was increased in ADX rats, by accelerating neutrophil maturation steps in the bone marrow. The investigation of adhesive properties on neutrophil membranes indicated reduced and increased expressions of L-selectin on cells present in the bone marrow and circulating blood, respectively. Similar levels of L-selectin mRNA in both cells from ADX or non-manipulated rats suggest that these effects do not depend on gene expression. Even though no differences in the expression of $\beta_{2}$ integrin by neutrophils were detected, modulation on subsequent PMN activation may occur by adrenal hormones, since circulating neutrophils from ADX exhibit lower in vitro adherence to the endothelium. We conclude that adrenal hormones control the adhesive interactions of neutrophils with the bone marrow microenvironment and with the vascular endothelium chiefly by modulation of L-selectin on PMN membrane in a mechanism independent of L-selectin gene expression.
\end{abstract}

(C) 2006 Elsevier Ireland Ltd. All rights reserved.

Keywords: Adrenal deficiency; Neutrophils; Bone marrow; Adhesion molecules; L-selectin mRNA

\section{Introduction}

Glucocorticoids are well known antiinflammatory substances when used in pharmacological concentrations, and the adrenal cortex hormone production is increased during the course of an inflammatory response. In contrast, the effect of typical diurnal concentrations of these hormones on the mechanisms that support inflammatory responses is not well understood.

Leukocyte recruitment, one of the first steps in mounting an inflammatory response, is known to be altered in adrenalectomized $(\mathrm{ADX})$ rats, in which a higher influx of neutrophils into injured areas is observed, compared to control subjects (Hlower et al.. 1986; Abe et al.. 1995; Rovai et al., 1998; Leech et al.. 2(0)0). This higher influx is probably due to the loss of glucocorticoid negative control on the rolling and adhesion

\footnotetext{
- Corresponding author. Tel.: +55 1130912197 ; fax: +55 1138156593

E-mail address: sfarsky@usp.br (S.H.P.Farsky).
}

0303-7207/S - see front matter 92006 Elsevier Ireland Ltd. All rights reserved. doi: 10.1016/j.mce.2006.01.007 of leukocytes to postcapillary venules (Farsky et al.. 1995). Adrenalectomy of normal rats leads to an increase in rolling and adhesion of leukocytes to postcapillary venules in vivo. Similar results are obtained after inhibition of the corticosterone synthesis with metyrapone or inhibition of glucocorticoid receptors with mifepristone (RU 38486), suggesting that the corticosterone synthesized by the adrenal gland plays a role in negatively modulating the migration of blood cells from the vascular bed (Farsky et al., 1995).

The initial rolling behavior and the subsequent adherence to the vessel wall are influenced by the expression of adhesion molecules on the membranes of leukocytes and endothelial cells and changes in hemodynamic behavior of circulating cells (Gonzalez-Amaro and Sanchez-Madrid. 1999; Pearson and Lipowsky, 2000; Marshall and Haskard, 2002; Sun e1 al.. 2003). Transient expression of selectins on leukocytes and endothelial cells mediates rolling behavior (Zhao et al., 2001; Rosen. 2004), whereas the subsequent expression of $\beta_{2}$ integrin on leukocytes and its binding to immunoglobulin receptors on the endothelium 
+ Model

are responsible for adhesion (Hubbard and Rothlein. 2000; Hogg et al., 2002; Mclntyre et al., 2003). This same set of molecules contribute to maintaining leukocytes in the bone marrow compartment during the maturation phase of these cells, and changes in their expression or cleavage can alter the adhesion either to the bone marrow microenvironment or to the vascular endothelium (Van teden et al. 1997: Dimitroftet al. 2001; Carion et a... 2002).

Recent data strongly suggest that adhesion molecules also mediate signal transduction. Initial interaction between leukocytes and the endothelium induces bi-directional signaling, which mediates events that impel leukocytes onward through microcirculatory vessels, as well as their responsiveness, differentiation states and survival at sites of inflammation (Wang and Doerschuk, 20k2: Kluger. 2004; Puri et al.. 2004: Nourshargh and Marelli-Berg. 2005).

Glucocorticoids interfere with the expression of adhesion molecules, and this is thought to be the basis for the inhibition of rolling and adhesion of leukocytes to endothelial cells (Vakagawa et al. 1998; Waisman et al. 1998; Torsteinsdottir el at.. 1999: Fassbender et al.. 1999: Weber et al.. 2001, 2004: Kaname et al.. 2002). However, these results were obtained with very high doses of natural or synthetic hormones, and may not represent the normal mechanism responsible for the effects of cortical adrenal hormonal production.

The aim of the current study is to determine the influence of adrenal cortical hormones on the distribution of leukocytes between the bone marrow and the blood compartment, and on leukocyte migration to peripheral tissues independently of the occurrence of an injury. We show that adrenal hormones deficiency accelerates the maturation of bone marrow neutrophils resulting in a faster migration of these cells to the peripheral compartment. A reduced expression of L-selectin on bone marrow segmented-quiescent polymorphonuclear (PMN) cells may underlie the facilitation of cell migration to peripheral blood. In addition, the increased expression of the same molecule in blood PMN cells may favor the migration of leukocytes from blood vessels when adrenal glands are removed. Both alterations on L-selectin on PMN membranes were not generated by modifications on gene expressions. On the other hand, adrenal hormones seem to alter the subsequent PMN activation, given that $\beta_{2}$ integrin on its membranes was not altered and its in vitro ability to adhere to the endothelium was reduced.

\section{Material and methods}

2.1. Animals

Male Wistar rats weighing $180-250 \mathrm{~g}$ at the beginning of the experiments were used. The animals were allowed a standard pellet diet and water ad libitum. During experimental procedures the animals were anesthetized with pentobarbital sodium ( $65 \mathrm{mg} / \mathrm{kg}$ : intraperitoneally) to avoid any stress condition. All animal procedures were performed according to approved protocols and in accordance with recommendations for the proper use and care of laboratory animals.

\subsection{Surgical procedures}

Bilateral adrenalectomy was performed with entrance into the cavity through bilateral skin and muscle incisions. Adrenalectomized rats (ADX) were supplied with physiological saline solution in addition to water. In the set of shamoperated animals, surgical incisions, handling of the abdominal viscera, and closure of the incisions were of similar extent as those of actual surgery. No special postoperative care was required in this case. Surgical procedures were performed with pentobarbital sodium anaesthesia; the animals were used for 7 days postoperatively. Intact controls were kept under the same conditions as operated rats.

\subsection{Determination of corticosterone concentration by radioimmunoassay}

The concentration of corticosterone was determined by radioimmunoassay (RIA) after extraction from plasma using ethanol (1.ope $\%$-Jimene $>$ et al.. 1989). The mean assay sensitivity and intra and interassay coefficients of variation were $0.4 \mu \mathrm{g} / \mathrm{dL}$ and $6.7 \%$. The percentage of recovery after extraction was $80 \%$. All the samples obtained from each experiment were analyzed in duplicate in the same assay.

\subsection{Hematological parameters}

\subsubsection{Blood}

Animals were anaesthetized with pentobarbital sodium and whole blood samples were obtained via abdominal aorta punctures using EDTA $(1 \mathrm{mg} / \mathrm{mL}$. Sigma, St. Louis, MO, USA). Total cells were quantified using a Neubauer chamber. Differential leukocyte counts were performed on blood smears stained with May Grumwald-Giemsa solution (Sigma, St. Louis, MO, USA).

\subsubsection{Bone marrow}

Bone marrow cells were obtained by flushing the femoral cavity with MoCoy's 5A medium (Sigma, St. Louis, MO, USA) with EDTA $(1 \mathrm{mg} / \mathrm{mL}$ ). The number of total cells was quantified in Neubauer chamber. Differential counts were performed on the basis of 500 cells per slide in cytocentrifuge smears stained with May-Grumwald and Giemsa dye.

\subsection{Flow cytometry}

Leukocytes were isolated from blood collected from the abdominal aorta or from the bone marrow to quantify $L$-selectin or $\beta_{2}$ integrin expressions. Blood was collected using EDTA solution $2 \%$ and bone marrow content was harvested by perfusion with Hank's balanced solution (HBSS) containing BSA $1 \%$ and EDTA $10 \%$. In brief, erythrocyte lysis was performed using ammonium chloride solution $(0.13 \mathrm{M})$ in both samples and leukocytes were recovered after washing with HBSS. Cells $\left(1 \times 10^{6}\right)$ were incubated with or without $N$-formylmethionyl. leucyl-phenylalanine (fMLP $10^{-8} \mathrm{M} / 15$ or $30 \mathrm{~min}$ ).

After washing, leukocytes were further incubated for $20 \mathrm{~min}$ at $4{ }^{\circ} \mathrm{C}$ in the dark with $10 \mu \mathrm{L}$ of monoclonal antibody against L-selectin (FITC conjugated. mouse anti-rat L-selectin, BD PharMingen Technical, CA, USA, $50 \mathrm{mg} / \mathrm{mL}$ ) or $\beta_{2}$ integrin (FITC conjugated, mouse anti-rat $\beta_{2}$ integrin, BD PharMingen Technical, CA, USA, $50 \mathrm{mg} / \mathrm{mL}$ ). Immediately after incubation. cells were analyzed on a FACScalibur flow cytometer (Becton and Dickinson, San Jose, CA, USA). Data from 10,000 cells were obtained and only the morphologically viable leukocytes were considered for analysis. Results were expressed as fluorescence units.

\subsection{Determination of $L$-selectin $m R N A$ levels}

\subsubsection{RNA extraction}

Total RNA was extracted from neutrophils by the TRIzol ${ }^{\text {(x) }}$ Reagent method following the manufacturer's instructions. The RNA extraction was carried out in an RNAse-free environment. RNA was quantified by reading the absorbency

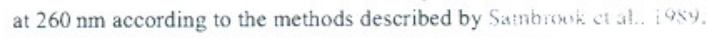

\subsubsection{RT-PCR}

The cDNAs were synthesized from $2 \mu \mathrm{g}$ of total RNA using oligo(dT) 15 primer $\left(20 \mu \mathrm{g} / \mathrm{mL}\right.$ ) (Promega), after incubation at $70^{\circ} \mathrm{C}$ for $5 \mathrm{~min}$. dNTP mix (2 mM) (Promega), RNasin Inhibitor (20U) (Promega) and M-MLV-RT 
+ Model

D.M.H. Cavalcanti et al. / Molecular and Cellular Endocrinology $x x x$ (2006) xox-xoxx

(200U) (Promega) were added with final volume of $25 \mu \mathrm{L}$ in buffer M-MLVRT (Promega). The reverse transcription occurred by incubation at $42^{\circ} \mathrm{C}$ for $60 \mathrm{~min}$. For the polymerase chain reaction (PCR), the cDNA obtained was incubated with $2.5 \mathrm{U}$ Taq DNA polymerase (Promega), $0.4 \mu \mathrm{M} \mathrm{3} 3^{\prime}$ and $5{ }^{\prime}$ specific primers and $200 \mu \mathrm{M}$ dNTP mix in buffer-thermophilic DNA polymerase (Promega), containing $1.5 \mathrm{mM} \mathrm{MgCl}$. The annealing temperature for $\mathrm{L}$-selectin and GAPDH was 51 and $54^{\circ} \mathrm{C}$, respectively, obtained in 30 cycles. The primers used were: L-selectin sense: $5^{\prime}$ AACGAGACTCTGGGAAGT' 3 : L-selectin antisense: 5'CAAAGGCTCACATTGGAT'3: GAPDH sense: 5'TATGATGACATCAAGAAGGTGG'3: GAPDH antisense: 5'CACCACCCTGTTGCTGTA'3. The PCR products were detected on $2 \%$ agarose electrophoresis stained with ethidium bromide using 100 or 50 bp ladder (Promega) as nucleotide size markers. A FLA-3000 scanner (Fuji film) scanned the gels and the densitometric analyses were obtained using the Total Lab Software. The target gene was amplified and the level of each expression was represented by the ratio of densities of the target genes versus the band corresponding to the GAPDH, a constitutive control gene.

\subsection{In vitro neutrophil-endothelium adherence}

2.7.1. Microvascular endothelial primary cultures

Primary cultures of microvascular endothelial cells were obtained from the rat cremaster muscle using the method described by Chen $\mathrm{N}$ al. (1945). Rats were anesthetized and non-coagulated by intraperitoneal injection of heparin (Liquimine ${ }^{\star}$, Roche, 1000 units per animal). The animals were exsanguinated by cutting the bilateral carotid arteries. Subsequently the cremaster muscles were isolated, cut into pieces of approximately $2 \mathrm{~mm} \times 2 \mathrm{~mm}$, and two pieces were placed into a flask and cultured in DMEM supplemented with $20 \%$ fetal calf serum and $1 \%$ penicillin/streptomycin. After $48 \mathrm{~h}$, the tissues were discarded and the medium changed. The flask contained only endothelial cells and blood cells. The cells were sub-cultured with $10 \%$ pancreatin in PBS solution and used for an adherence assay on the 8 th day, when they achieved confluence. The endothelial identification was performed by adding monoclonal antibody against PECAM-1 (Becton and Dickinson, San Jose, CA, USA, $50 \mathrm{mg} / \mathrm{mL}$ ).

\subsubsection{PMN cell-enriched leukocytes}

Blood was collected from the abdominal aorta of anesthetised rats using EDTA $2 \%$. Cell separation was performed by adding $3 \mathrm{~mL}$ of Percoll $(56 \%$ in sterile PBS) to $5 \mathrm{~mL}$ of blood samples. After centrifugation ( $1000 \times \mathrm{g}, 40 \mathrm{~min})$, the interface containing mainly PMN cells was collected and erythrocyte lysis was promoted by adding lysis solution $\left(\mathrm{NH}_{4} \mathrm{Cl} 8.02 \mathrm{~g} / \mathrm{L}, \mathrm{NaHCO}_{3} 0.84 \mathrm{~g} / \mathrm{L}\right.$ ). An amount of $10^{6}$ cells $/ \mathrm{mL}$ were suspended in HBSS with $0.5 \%$ BSA and used for an adherence assay.

2.7.3. Adherence assay

First-passage endothelial cells were plated in $6.4 \mathrm{~mm}$ diameter wells at $10^{4}$ cells $/ \mathrm{mL}$ in DMEM supplemented with $20 \%$ fetal calf serum. Cells were washed with three-well volume exchange of HBSS and PMN cells $\left(10^{5}\right.$ cells $/ 50 \mu \mathrm{L} /$ well $)$ were than added in HBSS containing $0.5 \%$ BSA. Endothelial and PMN cells were incubated for $5 \mathrm{~min}\left(37^{\circ} \mathrm{C}, 5 \% \mathrm{CO}_{2}\right)$. Nonadherent PMN cells were washed with a two-well volume exchange of HBSS. A colorimetric tetramethylbenzidine (TMB) assay was then applied to detect neutrophils adhering to the monolayers, using TMB as a peroxidase substrate. Fifty microlitres of acetate buffer $(0.05 \mathrm{M}, \mathrm{pH} 5.8)$ containing $0.25 \%$ of dodecyltrimethylammonium bromide as peroxidase solubilizing and $25 \mu \mathrm{L}$ of TMB ( $16 \mathrm{mM}$ in dimethylsulfoxide) were added and incubated for $5 \mathrm{~min}$ at room temperature. Subsequently, $100 \mu \mathrm{L}$ of hydrogen peroxidase (final concentration of $2.5 \mathrm{nM}$ ) were added. After $2 \mathrm{~min}$, the peroxidase reaction was stopped by the addition of $50 \mu \mathrm{L}$ of sulfuric acid $(1 \mathrm{M})$. The absorbance was determined at $420 \mathrm{~nm}$ using an ELISA microplate reader (spectraMAX 250. Molecular Devices). PMN adherence was calculated using a calibration curve obtained by performing the peroxidase reaction in wells containing known amounts of neutrophils.

\subsection{Statistical analysis}

Means and standard errors of means (S.E.M.) of data are presented and were compared by analysis of variance (ANOVA) or Tukey Multiple Comparisons Test with a significant probability of less than 0.05 . L-selectin $m R N A$ levels are expressed as mean of two assays performed in duplicate.

\section{Results}

\subsection{Corticosterone levels}

Adrenalectomy ( 7 days) reduced plasma concentration of corticosterone from $6.43 \mu \mathrm{g} / \mathrm{dL} \pm 0.71(n=9$; normal) to $0.43 \mu \mathrm{g} / \mathrm{dL} \pm 0.03(n=9, \mathrm{ADX}, p<0.05)$, confirming the efficacy of adrenal removal surgery. In addition, no significant difference in corticosterone levels was detected between normal and sham-operated animals $(6.92 \mu \mathrm{g} / \mathrm{dL} \pm 0.69, n=9)$ after 7 days of surgery, indicating that corticosterone returned to basal levels in sham-operated rats.

\subsection{Effects of adrenal deficiency on the production and maturation of segmented and mononuclear cells}

Adrenalectomy increased the number of total circulating leukocytes (Fig. I A), which reflected in an increment in the number of PMN cells (Fig. IB). The adrenal ablation did not modify the number of mononuclear (MN) leukocytes (data not shown). No changes in the numbers of progenitor cells of MN or PMN lineages in the bone marrow compartment were observed (data not shown), although a shunting line to the left in the PMN sector was detected. In fact, this deviation was compensated by an increased number of band PMN cells and a reduced number of immature PMN cells ( Fig. 2). No modification in the number of PMN cells in the last phase of maturation was detected (Fig. 2), probably due to their enhanced migration to the circulating compartment, as shown in Fig. IA.
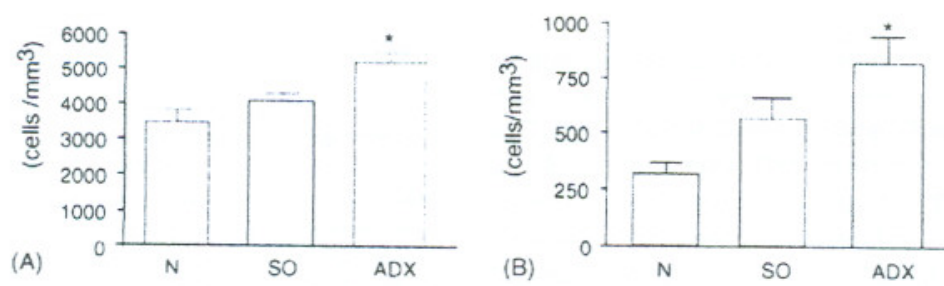

Fig. 1. Number of total leukocytes (A) and PMN cells (B) in the circulation compartment of normal (N), sham-operated (SO) or adrenalectomized (ADX) rats. Cells were collected 7 days after surgeries. Data are expressed as mean \pm S.E.M. of values obtained in six animals in each group. " $p<0.01$ vs. SO or $\mathrm{N}$ values. 
Anexo 2. Trabalho apresentado: CAVALCANTI; D.M.H.; LOTUFO, C.M.C.; BORELLI, P.;

MARKUS, R.P.; FARSKY, S.H.P. Adrenal deficiency alters mechanisms of neutrophil

mobilization. Molecular and Cellular Endocrinology, 2006

+ Model
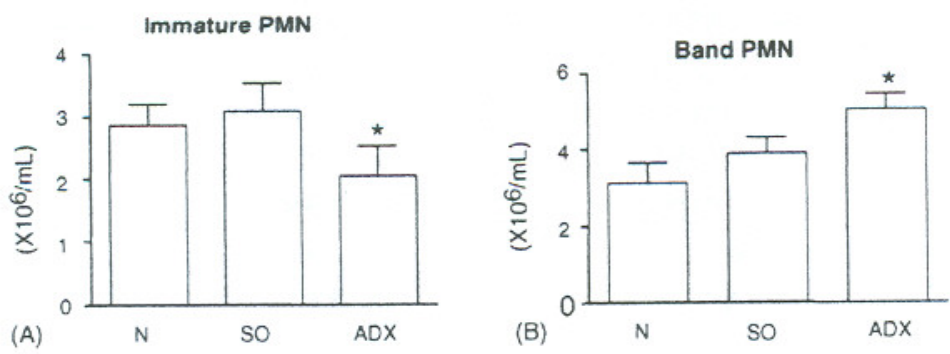

Segmented PMN

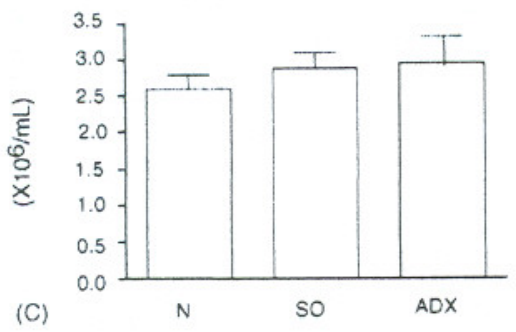

Fig. 2. Number of immature (A), band (B) or segmented PMN cells (C) from bone marrow of normal (N), sham-operated (SO) or adrenalectomized (ADX) rats. Cells were collected 7 days after surgeries. Data are expressed as mean \pm S.E.M. of values obtained in six animals in each group. $" p<0.05$ vs. SO or $\mathrm{N}$ values.

\subsection{Effects of adrenal deficiency on L-selectin and $\beta_{2}$ integrin expressions on bone marrow leukocytes}

To evaluate a possible role of adhesion molecules on accelerated PMN maturation, the expressions of L-selectin or $\beta_{2}$ integrin were investigated. Immature and band PMN cells from $\mathrm{ADX}$ animals presented $\mathrm{L}$-selectin expression comparable to cells from control animals (data not shown). However, segmented PMN cells obtained from ADX rats presented reduced expression of L-selectin when compared with cells collected from $\mathrm{SO}$ or $\mathrm{N}$ rats (Fig. 3A). In contrast, in vitro stimulation (fMLP $10^{-8} \mathrm{M}$ ) promoted similar increase on L-selectin expression in all groups of cells tested (Fig. 3A). Expression of $\beta_{2}$ integrin was not altered, neither under quiescent nor stimulated conditions, in all phases of PMN maturation (Fig. 3B). In addition, adrenal deficiency did not modify the expressions of both molecules on any stage of maturation of MN cells (data not shown).

\subsection{Effects of adrenal deficiency on L-selectin and $\beta_{2}$ integrin expression on circulating leukocytes}

Adrenalectomy promoted an increase on L-selectin expression on the membrane of total leukocytes (Fig. 4A), which reflected a marked increased on PMN population (Fig. 4B). The enhanced expression of L-selectin by PMN after in vitro addition of fMLP was similar in the three groups of cells tested (Fig. 4B). Conversely, adrenalectomy did not modify the expression of Lselectin on MN cells, since expression levels were not different than those from control cells, even on quiescent or fMLP stimulated cell membranes. Additionally, results presented in Fig. 5A showed that the expression of $\beta_{2}$ integrin on total circulating leukocytes, such as on PMN (Fig. 5B) and on MN cells (data not shown), did not differ among cells obtained from the three groups of animals.
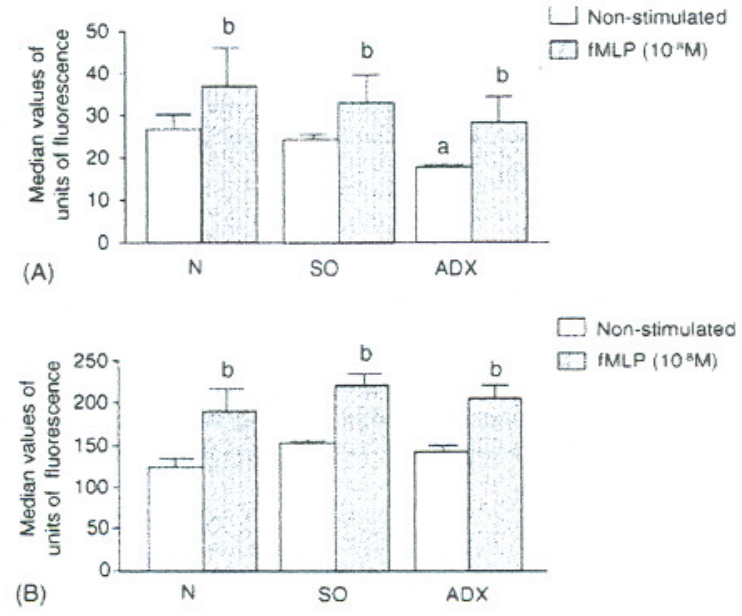

Fig. 3. Expression of adhesion molecules on segmented PMN cells from bone marrow. Data were obtained by blood flow cytometry analysis. Panel (A) represents $L$-selectin expression and panel $(B)$ represents $\beta_{2}$ integrin expression. White columns show values obtained in non-stimulated cells and striped columns show values obtained after stimulation by fMLP $\left(10^{-8} \mathrm{M}\right)$. Cells were collected 7 days after surgeries. Results express mean \pm S.E.M of cells collected from six to eight non-manipulated $(\mathrm{N})$, sham-operated $(\mathrm{SO})$ and adrenalectomized (ADX) rats. ${ }^{a} p<0.05$ vs. $\mathrm{SO}$ or $\mathrm{N}$ non-stimulated values; ${ }^{b} p<0.05$ vs. respective non-stimulated condition. 
+ Model
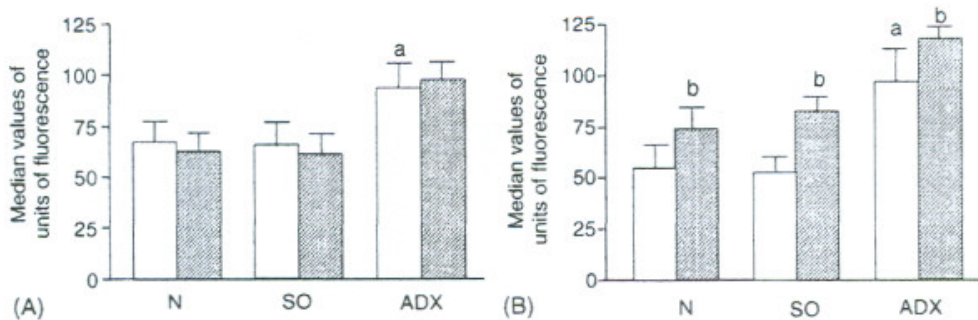

Fig. 4. Expression of L-selectin on total leukocytes (panel A) and on PMN circulating cells (panel B). Data were obtained by blood flow cytometry analysis. White columns show values obtained in non-stimulated cells and striped columns show values obtained after stimulation by $\mathrm{MLP}\left(10^{-8} \mathrm{M}\right)$. Cells were collected 7 days after surgeries. Results express mean \pm S.E.M of cells collected from six to eight non-manipulated $(\mathrm{N})$, sham-operated (SO) and adrenalectomized (ADX) rats. ${ }^{a} p<0.05$ vs. non-stimulated $\mathrm{SO}$ or $\mathrm{N}$ values; ${ }^{b} p<0.05$ vs. respective non-stimulated condition.

\subsection{Effects of adrenal deficiency on L-selectin mRNA levels}

To investigate if modifications on membrane expression of L-selectin were dependent on alterations in gene expression, levels of mRNA were evaluated in bone marrow segmented cells and circulating PMN. Data obtained showed equivalent levels of L-selectin mRNA in both types of cells from ADX and nonmanipulated rats (Fig. 6).

\subsection{Effects of adrenal deficiency on neutrophil adherence}

We performed in vitro assays using circulating neutrophils and cultured endothelium to investigate whether the deficiency

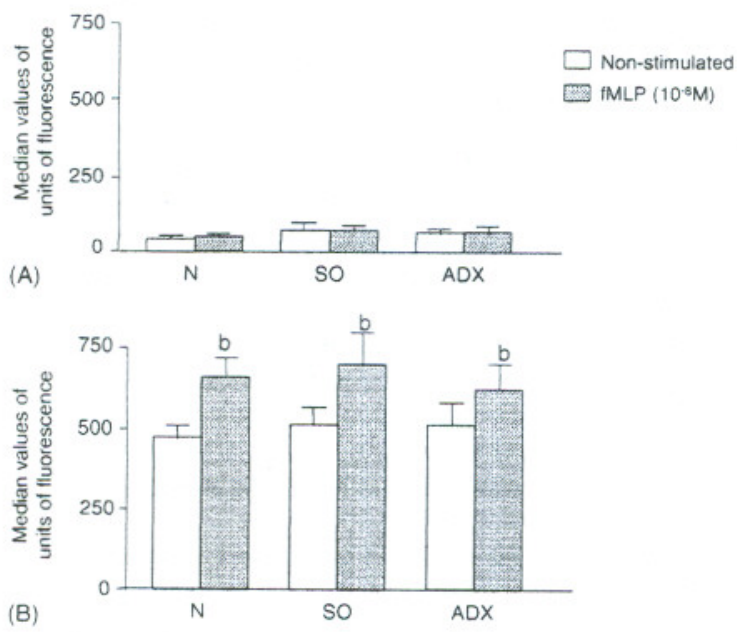

Fig. 5. Expression of $\beta_{2}$ integrin on total leukocytes (panel A) and on PMN circulating cells (panel B). Data were obtained by blood flow cytometry analysis. White columns show values obtained in non-stimulated cells and striped columns show values obtained after stimulation by $\operatorname{PLP}\left(10^{-8} \mathrm{M}\right)$. Cells were collected 7 days after surgeries. Results express mean \pm S.E.M of cells collected from six to eight non-manipulated $(\mathrm{N})$, sham-operated $(\mathrm{SO})$ and adrenalectomized $(A D X)$ rats. ${ }^{b} p<0.05$ vs. respective non-stimulated condition. of adrenal hormones affected the ability of neutrophils to adhere to the endothelium. Our data showed that the number of neutrophils from ADX animals adhering to normal endothelium was significantly smaller than the number of neutrophils collected from $\mathrm{SO}$ or $\mathrm{N}$ rats (Fig. 7).

\section{Discussion}

The present study described the alterations elicited by deficiency of adrenal hormones on neutrophil behavior during their mobilization steps. Most importantly, they suggest that adrenal hormones modulate adhesive properties promoted by L-selectin in the bone marrow and circulation in a mechanism independent of L-selectin gene expression.

Recruitment of neutrophils from bone marrow is a characteristic phenomenon of different types of stress, and it is modulated by elevated concentrations of glucocorticoids. Neutrophilia has been fully detected in experimental animals and humans after dexamethasone injection (Burton et al.. 1995; Nakagawa et al.. 1999; Weber et al., 2004) or during special physiological conditions, such as periparturient cows and neonatal calves (Lee and Kehrli, 1998; Preisler et al., 2000). The mechanisms involved are associated to demargination of immature cells (Meagher et al. 1996) or to impairment of neutrophil apoptosis (Liles et al. 1995; Chang et al., 2004). However, to our knowledge it has not hitherto been demonstrated that depletion of endogenous adrenal hormones induces neutrophilia in the absence of stress stimulus, by inducing accelerated delivery of cells from bone marrow to blood, as suggested here by adrenalectomy. Our data also show that the mechanisms involved may be related to the expression of adhesion molecule on neutrophils, since impairment on L-selectin expression on segmented cells at the last phase of maturation in the bone marrow compartment was observed in cells from ADX animals. The modulation of Lselectin expression on bone marrow neutrophils by elevated concentrations of glucocorticoids had already been suggested (Weber et al. 2001), and inferred as a possible determinant of neutrophilia. However, this effect was recently questioned 


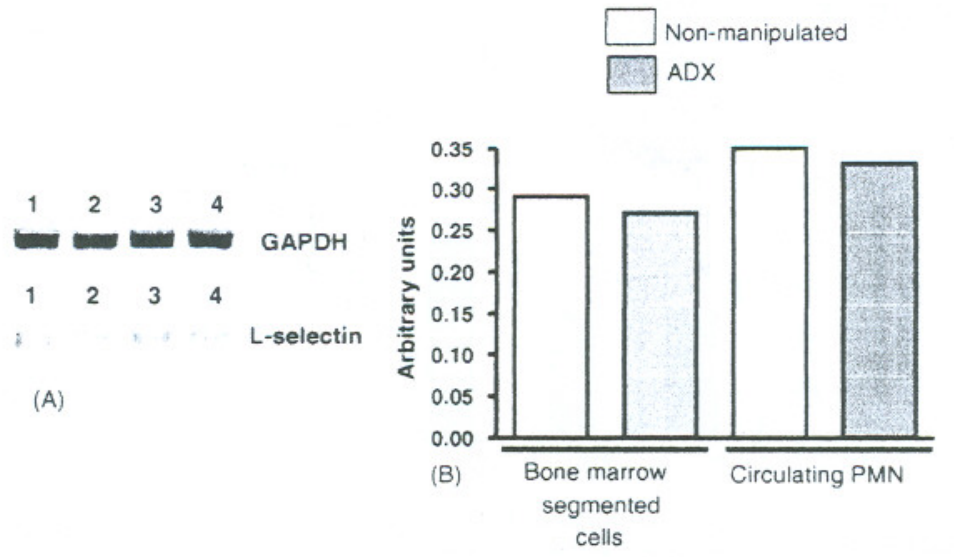

Fig. 6. Representative gel of PCR products and result of L-selectin:GAPDH ratios. (A) Agarose gel visualised under ultraviolet light using the fluorescent properties of ethidium bromide and scanned using FLA-3000 scanner (Fuji film). PCR products for L-selectin from a control bone marrow PMN in lane 1 and ADX bone narrow PMN in lane 2. with their respective GAPDH in lanes 3 and 4 are shown. (B) Densitometric analysis of L-selectin RT-PCR products standardized according to the corresponding GAPDH RT-PCR product levels. Data represent two independent experiments performed in duplicate.

in a bovine experimental model. It was suggested that dexamethasone downregulates L-selectin expression predominantly on the membrane of circulating neutrophils, through activation of glucocorticoid receptor and subsequent effects on intracellular reservoirs of L-selectin mRNA (Weher et al.. 2004). It is interesting to note that the impairment on L-selectin expression on segmented bone marrow cells from ADX detected here, does not reflect a defect on the synthesis or expression machineries of Lselectin, given that L-selectin mRNA levels and the enhanced expression of the molecule under in vitro fMLP stimulation was similar in PMN cells from ADX and controls rats. Van keden er a1. (1997) showed that L-selectin shedding occurs in PMN moving from the hematopoietic compartment, and suggested that this could control the release of PMN from the bone marrow. Thus, endogenous adrenal hormones may control L-selectin shedding on the segmented bone marrow, modulating its delivery to the circulation.

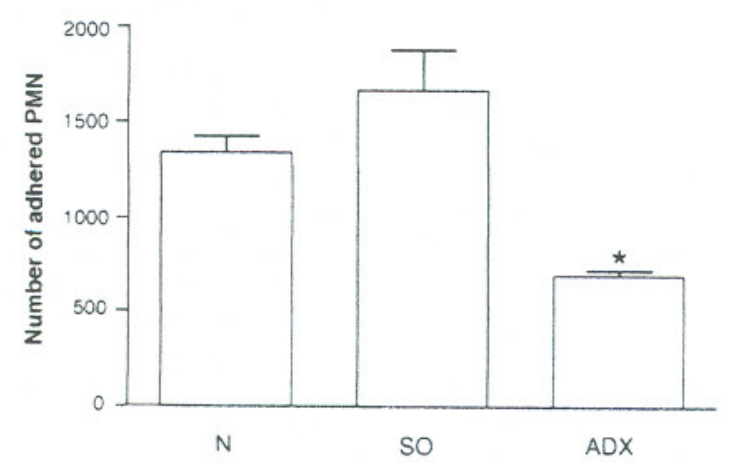

Fig. 7. Number of polymorphonuclear cells from ADX, SO or N rats adhered to cultured endothelium. Data express the mean \pm S.E.M. of values obtained from four animals in each group. Cells were collected 7 days after surgeries. " $p<0.05$ vs. $\mathrm{SO}$ or $\mathrm{N}$ values.
Interestingly, data herein show that on the circulating PMN cells, L-selectin expression is inversely modulated by adrenal hormones in comparison to bone marrow cells, as demonstrated by an increment on expression of L-selectin on peripheral neutrophils collected from ADX rats. These data corroborate the action of glucocorticoids on the molecule expression, since impairment on its expression is observed by elevated endogenous glucocorticoids concentrations during several pathophysiological conditions (Filep et al., 1997: Fasshender et al., 199\%. Nakagawa et al. 1998; Torsteinsdottir et al., 1999: Weber tal al. 2001. 2004; Kaname e1 al. 2002). The mechanism proposed is mainly based on a genomic hormonal action that induces reduction on L-selectin mRNA levels (Weber et al. 2001. 20044). However, the equivalent levels of L-selectin mRNA in circulating PMN from ADX and non-manipulated rats found here do not confirm the role of adrenal hormones on L-selectin induced synthesis. In addition, this result may indicate the induction of Lselectin shedding as a physiological action of adrenal hormones on the control of leukocyte-neutrophil interactions. Consistent with our hypothesis, Stratsbaugh and Rosen (2001) showed that annexin I, a protein suggested as responsible for some antiinflamamtory effects of glucocorticoids, induced a dose-response decrease in L-selectin on neutrophil and monocyte membranes, by evoking its shedding. Also, it was shown that clinical concentrations of dexamethasone reduce the shedding of $\mathrm{L}$-selectin induced by PAF (Filep el al.. 1997).

It has been shown that the blockage of $\mathrm{L}$-selectin shedding on PMN membranes during an inflammatory response increase the number and transit time of rolling cells on activated endothelium, resulting in elevated adherence and transmigration (Walcheck et al. 1996: Haferi-Moghadam and Ley. 1999; Haferi-Moghadam et al., 2001: Venturi et al. 2003; Smalley and Lev. 2005). A similar pattern of response was observed after inducting a local inflammatory reaction in ADX and metyrapone-treated rats (Farsky el al. 1995). 
+ Model

D.M.H. Cavalcanti et al. / Molecular and Cellular Endocrinology $x x x$ (2006) $x x x-x x x$

Cross-linking of L-selectin in an inflammatory process initiates intracellular signaling and participates of PMN activation during adherence and transmigration by enhancing neutrophil ability to deform and $\beta_{2}$ integrin activation (Crockett-Torabi et al. 1995: Simon el al. 1995, 1999). We expected that in ADX animals the expression of $\beta_{2}$ integrin would be increased, with consequent cellular activation. However, our results do not confirm this hypothesis because of the following observations: (1) adrenalectomy did not modify $\beta_{2}$ integrin expression on membrane of PMN cells and (2) circulating neutrophils from ADX animals lost their capacity to adhere to normal cultured endothelium. Our results may indicate that physiological control of subsequent steps of rolling behavior by adrenal hormones may be different during disease or after exogenous therapy. In this context, it has been shown that the effects of glucocorticoid hormones on adherence and on $\beta_{2}$ integrin expression are controversial, and seem to be dependent on hormonal concentrations. In vitro or in vivo assays carried out with pharmacological doses of dexamethasone inhibited $\beta_{2}$ integrin expression (Youssef et al.. 1995, 1996, Filep et al.. 1997; Lim et al., 2000), but the blockage of glucocorticoid synthesis in rheumatoid patients, with elevated concentration of cortisol, did not alter the pattern of integrin expression (Torsteinsdottir er al.. 1999). Additionally, House et al. (1997) showed that differences on corticosteroid concentrations induced by the circadian rhythm alters the adherence of leukocyte to postcapillary venule walls in vivo throughout the day. Higher adherence of leukocytes to postcapillary venules was detected at elevated concentrations of corticosteroids.

Taken together, our data demonstrate the physiological control by adrenal hormones of neutrophil events responsible for cellular interactions during their mobilization. L-selectin expression on PMN membranes seems to be essential to maintain these cells at their specific compartment during production and distribution, independently of its gene expression. Our results provide a better understanding of physiological modulation of adrenal hormones on mechanisms involved on leukocyte recruitment.

\section{Acknowledgements}

The authors thank Pricila de Paulo Araujo, Ricardo A. Fock and Jorge M. Ferreira Jr. for technical assistance and Dr. José A. Rodrigues for providing corticosterone antibody. This work was supported by FAPESP grants \#03/09410-5. Regina P. Markus and Sandra H.P. Farsky are fellows of the Conselho Nacional de Pesquisa e Tecnologia (CNPq). Danielle M.H. Cavalcanti is a $\mathrm{CNPq}$ graduate fellow.

\section{References}

Abe, R., Shimosegawa, T., Kimura, K., Abe, T., Kashimura, J., Koizumi, M., Toyota, T., 1995. The role of endogenous glucocorticoids in rat experimental models of acute pancreatitis. Gastroenterology 109, 933-943.

Burton, J.L., Kehrli Jr., M.E., Kapil, S., Horst, R.L., 1995. Regulation of L-selectin and CDI8 on bovine neutrophils by glucocorticoids: effects of cortisol and dexamethasone. J. Leukoc. Biol. 57, 317-325.

Carion, A., Domenech, J., Herault, O., Benboubker, L., Clement, N., Bernard, M.C., Desbois, 1., Colombat, P., Binet, C., 2002. Decreased stroma adhesion capacity of $\mathrm{CD} 34+$ progenitor cells from mobilized peripheral blood is not lineage- or stage-specific and is associated with low beta 1 and beta 2 integrin expression. J. Hematother. Stem. Cell. Res. 11, 491500 .

Chang, L.C., Madsen, S.A., Toelboell, T., Weber, P.S., Burton, J.L., 2004 Effects of glucocorticoids on Fas gene expression in bovine blood neutrophils. J. Endocrinol. 183, 569-583.

Chen, S.F., Fei, X., Li, S.H., 1995. A new simple method for isolation of microvascular endothelial cells avoiding both chemical and mechanical injuries. Microvasc. Res. 50, 119-128.

Crockett-Torabi, E., Sulenbarger, B., Smith, C.W., Fantone, J.C.. 1995. Activation of human neutrophils through L-selectin and Mac-l molecules. J. Immunol. 154, 2291-2302.

Dimitroff, C.J., Lee, J.Y., Schor, K.S., Sandmaier, B.M., Sackstein, R., 2001. Differential $\mathrm{L}$-selectin binding activities of human hematopoietic cell $\mathrm{L}$ selectin ligands, HCELL and PSGL-1. J. Biol. Chem. 276, 47623-4763!

Farsky, S.P., Sannomiya, P., Garcia-Leme, J., 1995. Secreted glucocorticoids regulate leukocyte-endothelial interactions in inflammation. A direct vital microscopic study. J. Leukoc. Biol. 57, 379-386.

Fassbender, K., Kaptur, S., Becker, P., Groschel, J., Schmidt, R., Hennerici. M., 1999. Inverse association between endogenous glucocorticoid secretion and L-selectin (CD62L) expression in trauma patients. Life Sci. 29. $2471-2480$

Filep, J.G., Delalandre, A., Payette, Y., Foldes-Filep, E., 1997. Glucocorticoid receptor regulates expression of $\mathrm{L}$-selectin and $\mathrm{CD} 1 \mathrm{1} / \mathrm{CD} 18$ on human neutrophils. Circulation 96, 295-301.

Flower, R.J., Parente, L., Persico, P., Salmon, J.A., 1986. A comparison of the acute inflammatory response in adrenalectomised and sham-operated rats. Br. J. Pharmacol. 87, 57-62.

Gonzalez-Amaro, R., Sanchez-Madrid, F., 1999. Cell adhesion molecules. selectins and integrins. Crit. Rev. Immunol. 19, 389-429.

Hafezi-Moghadam, A., Thomas, K.L., Prorock, A.J., Huo, Y., Ley, K., 2001 L-selectin shedding regulates leukocyte recruitment. J. Exp. Med. 193, 863-872.

Hafezi-Moghadam, A., Ley, K., 1999. Relevance of L-selectin shedding for leukocyte rolling in vivo. J. Exp. Med. 189, 939-947.

Hogg, N., Henderson, R., Leitinger, B., McDowall, A., Porter, J., Stanley, P. 2002. Mechanisms contributing to the activity of integrins on leukocytes Immunol. Rev. 186, 164-171.

House, S.D., Ruch, S., Koscienski Ill, W.F., Rocholl, C.W., Moldow. R.L., 1997. 1997 Effects of the circadian rhythm of corticosteroids on leukocyte-endothelium interactions in the $\mathrm{AM}$ and PM. Life Sci. 60 2023-2034.

Hubbard, A.K., Rothlein, R., 2000. Intercellular adhesion molecule-1 (ICAM1) expression and cell signaling cascades. Free Radic. Biol. Med. 28 . 1379-1386.

Kaname, H., Mori, Y., Sumida, Y., Kojima, K., Kubo, C., Tashiro, N., 2002. Changes in the leukocyte distribution and surface expression of adhesion molecules induced by hypothalamic stimulation in the cat. Brain Behav, Immunol. 16, 351-367.

Kluger, M.S., 2004. Vascular endothelial cell adhesion and signaling during leukocyte recruitment. Adv. Dermatol. 20, 163-201,

Lee, E.K., Kehrli Jr., M.E., 1998. Expression of adhesion molecules on neutrophils of periparturient cows and neonatal calves. Am. J. Vet. Res. 59. $37-43$.

Leech, M., Huang, X.R., Morand, E.F., Holdsworth, S.R., 2000. Endogenous glucocorticoids modulate experimental anti-glomerular basement membrane glomerulonephritis. Clin. Exp. Immunol. 119, 161-168.

Liles, W.C., Dale, D.C., Klebanoff, S.J., 1995. Glucocorticoids inhibit apoptosis of human neutrophils. Blood $86,3181-3188$.

Lim, L.H., Flower, R.J., Perretti, M., Das, A.M., 2000. Glucocorticoid receptor activation reduces CD11 b and CD49d levels on murine eosinophils: characterization and functional relevance. Am. J. Respir. Cell. Mol. Biol. 22, 693-701

Lopez-Jimenez, M., Valenca, M.M., Moreira, A.C., Antunes-Rodrigues, J.. 1989. Ether and immobilization stress effects on pituitary adrenal function in hemidecorticate rats. Braz. J. Med. Biol. Res. 22, 779-782.

Marshall, D., Haskard, D.O., 2002. Clinical overview of leukocyte adhesion and migration: where are we now? Semin. Immunology 14, 133-140. 
Mclntyre, T.M., Prescott, S.M., Weyrich, A.S., Zimmerman, G.A., 2003. Cell-cell interactions: leukocyte-endothelial interactions. Curr. Opin Hematol. 10, 150-158

Meagher, L.C., Cousin, J.M., Seckl, J.R., Haslett, C., 1996. Opposing effects of glucocorticoids on the rate of apoptosis in neutrophilic and eosinophilic granulocytes. J. Immunol. 156, 4422-4428.

Nakagawa, M., Bondy, G.P., Waisman, D., Minshall, D., Hogg, J.C., van Eeden, S.F., 1999. The effect of glucocorticoids on the expression of L-selectin on polymorphonuclear leukocyte. Blood 93, 2730-2737.

Nakagawa, M., Terashima, T., D'yachkova, Y., Bondy, G.P., Hogg, J.C., van Eeden, S.F., 1998. Glucocorticoid-induced granulocytosis: contribution of marrow release and demargination of intravascular granulocytes. Circulation $98,2307-2313$.

Nourshargh, S., Marelli-Berg, F.M., 2005. Transmigration through venular walls: a key regulator of leukocyte phenotype and function. Trends Immunol. 26, 157-165.

Pearson. M.J., Lipowsky, H.H., 2000. Influence of erythrocyte aggregation on leukocyte margination in postcapillary venules of rat mesentery. Am. J. Physiol. Heart Circ. Physiol. 279, 1460-1471.

Preisler, M.T., Weber, P.S., Tempelman, R.J., Erskine, R.J., Hunt, H., Burton, J.L.., 2000. Glucocorticoid receptor down-regulation in neutrophils of periparturient cows. Am. J. Vet. Res. 61, 14-19.

Puri, K.D., Doggett, T.A., Douangpanya, J., Hou, Y., Tino, W.T., Wilson. T. Graf, T., Clayton, E., Turner. M. Hayflick. J.S., Diacovo, T.G., 2004. Mechanisms and implications of phosphoinositide 3-kinase delta in promoting neutrophil trafficking into inflamed tissue. Blood 103. 3448-3456.

Rosen. S.D., 2004. Ligands for L-selectin: homing, inflammation, and beyond. Annu. Rev, Immunol. 22, 129-156.

Rovai, L.E., Herschman, H.R., Smith, J.B., 1998. The murine neutrophilchemoattractant chemokines LIX, KC, and MIP-2 have distinct induction kinetics, tissue distributions, and tissue-specific sensitivities to glucocorticoid regulation in endotoxemia. J. Leukoc. Biol. 64, 494-502.

Sambrook, J., Fritsch, E.F., Maniatis, T., 1989. Molecular Cloning Laboratory Manual, 2nd ed. Cold Spring Harbor Laboratory Press, United States of America, pp. 7-8.

Simon, S.I., Burns, A.R., Taylor, A.D., Gopalan, P.K., Lynam, E.B., Sklar, L.A., Smith, C.W., 1995, L-selectin (CD62L) cross-linking signals neutrophil adhesive functions via the Mac-1 (CD1/b/CD18) beta 2 integrin J. Immunol. 155, 1502-1514

Simon, S.I., Cherapanov, V., Nadra, 1., Waddell. T.K., Seo, S.M., Wang, Q.. Doerschuk, C.M., Downey, G.P., 1999. Signaling functions of L. selectin in neutrophils: alterations in the cytoskeleton and colocalization with CD18. J. Immunol. 163, 2891-2901.

Smalley, D.M., Ley, K., 2005. L-selectin: mechanisms and physiological significance of ectodomain cleavage. J. Cell. Mol. Med. 9. 255-266
Strausbaugh, H.J., Rosen, S.D., 2001. A potential role for annexin i as physiologic mediator of glucocorticoid-induced L-selectin shedding from myeloid cells. J. Immunol. 166, 6294-6300.

Sun, C., Migliorini, C., Munn, L.L., 2003. Red blood cells initiate leukocyte rolling in postcapillary expansions: a lattice Boltzmann analysis. Biophys J. $85,208-222$.

Torsteinsdottir, 1., Arvidson, N.G., Hallgren, R., Hakansson, L., 1999. Enhanced expression of integrins and CD66b on peripheral blood neutrophils and eosinophils in patients with rheumatoid arthritis, and the effect of glucocorticoids. Scand. J. Immunol. 50, 433-439.

Van Eeden, S.F. Kitagawa, Y., Klut, M.E. Lawrence, E., Hogg, J.C. 1997. Polymorphonuclear leukocytes released from the bone marrow preferentially sequester in lung microvessels. Microcirculation 4, 369-380.

Venturi, G.M. Tu, L., Kadono, T. Khan, A.I., Fujimoto, Y. Oshel, P.. Bock. C.B., Miller, A.S., Albrecht, R.M., Kubes, P., Steeber, D.A., Tedder. T.F., 2003. Leukocyte migration is regulated by L-selectin endoproteolytic release. Immunity $19,713-724$.

Waisman, D., Van Eeden, S.F., Hogg, J.C., Solimano, A., Massing, B., Bondy, G.P., 1998. L-selectin expression on polymorphonuclear leukocytes and monocytes in premature infants: reduced expression afer dexamethasone treatment for bronchopulmonary dysplasia. J. Pedriatr. 132, 53

Walcheck, B., Kahn, J., Fisher, J.M., Wang, B.B., Fisk, R.S., Payan, D.G. Feehan, C., Betageri, R., Darlak, K., Spatola, A.F., Kishimoto, T.K., 1996 Neutrophil rolling altered by inhibition of L-selectin shedding in vitro. Nature 380. 720-723.

Wang, Q., Doerschuk, C.M., 2002. The signaling pathways induced by neutrophil-endothelial cell adhesion. Antiox. Redox. Signal 4, 39-47.

Weber, P.S., Madsen, S.A., Smith, G.W., Ireland, J.J., Burton, J.L., 2001 Pre-translational regulation of neutrophil L-selectin in glucocorticoidchallenged cattle. Vet. Immunol. Immunopathol. 83, 213-240.

Weber, P.S., Toelboell, T., Chang, L.C., Tirrell, J.D., Saama, P.M., Smith. G.W., Burton, J.L., 2004. Mechanisms of glucocorticoid-induced downregulation of neutrophil L-selectin in cattle: evidence for effects at the gene-expression level and primarily on blood neutrophils. J. Leukoc. Biol. $75,815-827$

Youssef, P., Roberts-Thomson, P. Ahern, M., Smith, M. 1995 . Pulse methyl prednisolone in rheumatoid arthritis: effects on peripheral blood and synovial fluid neutrophil surface phenotype. J. Rheumatol. 22, 2065 2071.

Youssef, P.P., Cormack, J., Evill, C.A., Peter, D.T., Roberts-Thomson, P.I. Ahern, M.J., Smith, M.D., 1996. Neutrophil trafficking into inflamed joints in patients with rheumatoid arthritis, and the effects of methylprednisolone. Arthritis. Rheum. 39, 216-225.

Zhao, L.C.. Edgar, J.B., Dailey, M.O., 2001. Characterization of the rapid proteolytic shedding of murine L-selectin. Dev. Immunol. 8, 267-277. 


\title{
Toxicon
}

\section{Role of kinins and nitric oxide on the rabbit arthritis induced by Bothrops jararaca venom}

\author{
Maria Luiza Guzzo ${ }^{a}$, Sandra H.P. Farsky ${ }^{\text {, }}$, Gilberto De \\ Nucci $^{c}$, Edson Antunes ${ }^{c}$, Maria Aurora G. Silva ${ }^{a}$, Suzana \\ B.V. Mello ${ }^{\mathrm{a}, *}$ \\ "Rheumatology Division, Department of Internal Medicine, School of Medicine, University of São Paulo, \\ Av. Dr. Arnaldo 455, São Paulo, 0124-6903, SP, Brazil \\ ${ }^{\mathrm{b}}$ Lahoratory of Immunochemistry. Instituto Butantan, Av. Vital Brazil, 1500, São Paulo, 05503-900, SP. \\ Brazil \\ ${ }^{c}$ Pharmacology Division. School of Medicine, University of Campinas, PO Box 6111. Campinas, 13081. \\ 970, SP, Brazil
}

Received 12 October 1999; accepted 11 December 1999

\begin{abstract}
The effects of the nitric oxide synthase inhibitor $\mathrm{N}^{\omega}$ Nitro-L-arginine-methyl ester ( $\mathrm{L}$ NAME) and of the bradykinin $B_{2}$ receptor antagonist HOE 140 were evaluated in the inflammatory reaction induced by Bothrops jararaca venom (BjV) in New Zealand White rabbits. Arthritis was induced by injecting $0.5 \mathrm{ml}$ of a sterile solution of $\mathrm{BjV}(1-64 \mu \mathrm{g} / \mathrm{ml})$ into the knee intraarticular cavity. The contralateral joint was injected with bovine serum albumin (BSA) diluted in sterile saline. At selected times thereafter (4, 24 and $48 \mathrm{~h}$ ), the vascular permeability and the leukocyte influx in both the synovial fluid and synovium were evaluated. BjV caused a dose-dependent increase in both leukocyte influx and protein extravasation which reached a maximal response at $16 \mu \mathrm{g}$. Bothrops jararaca venom also induced the increase in the leukocyte accumulation in the synovium and in the concentration of both $\mathrm{NO}_{2} / \mathrm{NO}_{3}$ in the synovial fluid. Chronic administration of L-NAME $(20 \mathrm{mg} / \mathrm{kg} /$ day in the drinking water for 2 weeks) markedly reduced the leukocyte accumulation $(90 \%)$, protein leakage $(44 \%)$, and $\mathrm{NO}_{2} / \mathrm{NO}_{3}(50 \%)$ levels in the synovial fluid, measured at the 4 th h. Hoe 140 , given i.v. $(0.3 \mathrm{mg} / \mathrm{kg}, 30 \mathrm{~min}$ before $)$ also reduced leukocyte accumulation (75\%), protein leakage (48\%), and $\mathrm{NO}_{2} / \mathrm{NO}_{3}(79 \%)$ levels in the synovial fluid, measured at the 4 th $h$. Similar results were obtained with acute
\end{abstract}

\footnotetext{
* Corresponding author. Tel.: +55-011-30667492; fax: +55-011-30667490.
} 
administration of L-NAME (30 mg/kg, i.v., $30 \mathrm{~min}$ before). These results indicate that arthritis induced by $\mathrm{BjV}$ is triggered by kinin formation and that the increase in both vascular permeability and leukocyte accumulation is modulated by NO release. (C) 2000 Elsevier Science Ltd. All rights reserved.

\section{Introduction}

Bothropic snakes are responsible for about $90 \%$ of ophidic envenomation in Brazil and their venoms evoke a pronounced local tissue lesion characterised by haemorrhage, necrosis, inflammatory process and pain (Rosenfeld, 1971; Gutiérrez and Lomonte, 1989). The acute inflammatory reaction induced by Bothrops jararaca venom $(\mathrm{BjV})$ in the rat paw (Trebien and Calixto, 1989), rat pleurisy (Búrigo et al., 1996) and rat air-pouch (Farsky et al., 1997) is determined by oedema and leukocyte influx. These effects are multimediated with participation of histamine, serotonin, products of arachdonic acid metabolism, platelet activating factor (PAF) and factors derived from the complement system (Trebien and Calixto, 1989; Búrigo et al., 1996; Farsky et al., 1997). Although $\mathrm{BjV}$ induces bradykinin (Bk) formation (Rocha e Silva et al., 1949), there is no evidence of its contribution to the local lesion. Additionally, to several systemic effects, Bk stimulates the nitric oxide (NO) generation by endothelial cells or leukocytes at the site of the injury (Radomski et al., 1990). Since, the rat kinin system is different from the other species, including man, (Bhoola et al., 1992), we have investigated the interaction of $\mathrm{Bk}$ and $\mathrm{NO}$ in a rabbit model of arthritis.

The participation of $\mathrm{NO}$ in the intraarticular inflammatory process has been fully described in arthritic patients (St Clair et al., 1996; Novaes et al., 1997). Additionally, NO is produced by chondrocytes (Stadler et al., 1991; Palmer et al., 1993; Stefanovic-Racic et al., 1994a; Grabowski et al., 1996), synoviocytes (Grabowski et al., 1996; Stefanovic-Racic et al., 1994b), and osteoblasts (Grabowski et al., 1996). The administration of nitric oxide synthase (NOS) inhibitor in the experimental arthritis models is followed by a reduction of intraarticular accumulation of leukocytes and a reduction in swelling as well as in histopathological abnormalities (McCartney-Francis et al., 1993; Stefanovic-Racic et al., 1994c; Stefanovic-Racic et al., 1995; Veríssimo de Mello et al., 1997). Moreover, endogenous release of NO enhances macrophage cyclooxygenase (COX) activity that may result in the production of pro-inflammatory prostaglandins (Corbett et al., 1993; Salvemini et al., 1993).

Despite the fact that $\mathrm{BjV}$ activates the kinin system and $\mathrm{Bk}$ releases $\mathrm{NO}$ (De Nucci et al., 1988), the contribution of both inflammatory mediators has not been evaluated in this process. Then, in this study the participation of these mediators 
in the $\mathrm{BjV}$-induced arthrits was evaluated using the NO synthase inhibitor, LNAME and the bradykinin $B_{2}$ receptor antagonist HOE 140 .

\section{Material and methods}

\subsection{Venom}

Lyophilised BjV was supplied by the Butantan Institute (Brazil). The venom was maintained at $-20^{\circ} \mathrm{C}$, dissolved in sterile saline and filtered through a sterilising membrane (ester cellulose filter, $0.22 \mu \mathrm{m}$ pore size) before joint injection.

\subsection{Induction of arthritis}

The experimental protocol was approved by the Animal Ethics Committee of the Brazilian College of Experimental Animals. Arthritis was induced in the knee joint of adult male New Zealand White rabbits $(2 \mathrm{~kg})$ by injecting BjV $(1-64 \mu \mathrm{g} /$ $\mathrm{ml} ; 0.5 \mathrm{ml}$ ) into the articular cavity. The contralateral joint was injected with the same amount of bovine serum albumin (BSA) diluted in sterile saline and previously filtered. The amount of protein present in the BjV or BSA solution was spectrophotometrically assessed and an equivalent protein concentration was injected in each joint. After 4,24 or $48 \mathrm{~h}$ of the articular challenge, the animals were anaesthetised (xylazine $5 \mathrm{mg} / \mathrm{kg}$, i.m. and ketamine $50 \mathrm{mg} / \mathrm{kg}$, i.m.) and then sacrificed with $20 \% \mathrm{KCl}(2 \mathrm{ml}$, i.v.).

\subsection{Treatments}

Both L-NAME and D-NAME $(20 \mathrm{mg} / \mathrm{kg} / \mathrm{day})$ were administered in the drinking water for 2 weeks prior to the induction of arthritis. In a separate set of animals, L-NAME $(30 \mathrm{mg} / \mathrm{Kg}$, i.v.) was given as a single dose, $30 \mathrm{~min}$ prior to the venom administration. HOE 140 (D-Arg- $\left[\mathrm{Hyp}^{3}, \mathrm{Thi}^{5}, \mathrm{Dtic}^{5}, \mathrm{Oic}^{8}\right]$-bradykinin), a specific $\mathrm{B}_{2}$ receptor antagonist (Rhaleb et al., 1992; Brenner et al., 1993) $(0.3 \mathrm{mg} / \mathrm{kg}$, s.c.) was injected $30 \mathrm{~min}$ before $\mathrm{BjV}$ administration.

\subsection{Sampling of synovial fluid and measurement of leukocytes}

Immediately after sacrifice, $2 \mathrm{ml}$ of saline containing $0.1 \%$ EDTA was injected into the knee joint. The synovial fluid was aspirated, the joint opened and the remaining synovial fluid and the synovial membrane removed. Total leukocyte count was performed in a Neubauer chamber and the differential white cell was evaluated under light microscopy following Giemsa staining. 


\subsection{Assessment of vascular permeability response with Evans blue dve}

Briefly, before venom injection into knee joints, the animals received i.v. $20 \mathrm{mg} /$ $\mathrm{kg}$ of Evans's blue dye as a $2.5 \%$ solution in saline. The dye bind to plasma proteins resulting in a tagged macromolecule which passes the endothelial barrier in a negligible extent under normal conditions. However, it is raised in the synovial fluid under circumstances of increased vascular permeability. The synovial fluid was centrifuged and the optical density colorimetrically assessed at $630 \mathrm{~nm}$. The concentration of dye bound to protein in the synovial fluid was estimated from a standard graph recording the optical density of serial dilutions of a known sample of Evans blue in $\mathrm{NaCl}$. Results are expressed as $\mu \mathrm{g}$ of protein/ $\mathrm{ml}$ of synovial fluid.

\subsection{Synovial membrane histology}

The synovial membrane sections $(5 \mu \mathrm{m})$ were stained with hematoxylin and eosin for the quantification of PMN cell infiltrate under light microscopy. The results were expressed as cells/field by an observer blinded to the experimental groups.

\subsection{Total $\mathrm{NO}_{2} / \mathrm{NO}_{3}$ determination}

Total $\mathrm{NO}_{2} / \mathrm{NO}_{3}$ determination was realised by high performance liquid chromatography (HPLC) analysis (Muscará and De Nucci, 1996). After the passage of synovial fluid through a strong anion exchange column, two on line post column reactions occur. In the first, nitrate anions $\left(\mathrm{NO}_{3}\right)$ are reduced to nitrite $\left(\mathrm{NO}_{2}\right)$ on a copper-plated cadmium filled column, and in the second, a reaction with the Griess reagent takes place. The absorbance of the chromophore is read at $504 \mathrm{~nm}$. The method has a sensitivity of $30 \mathrm{pmol}$ for both anions.

\subsection{Materials}

Crystalline bovine albumin (fraction V), L-NAME and D-NAME were acquired from Sigma (St Louis, USA). Ester cellulose filters $(0.22 \mu \mathrm{m}$ pore size) was bought from Millipore (USA); xylazine from Bayer (Brazil); ketamine from Parke Davis (Brazil); EDTA and Evans blue dye from Merck (Brazil). Hoe 140 was kindly provided by Hoechst (Germany).

\subsection{Statistical analysis}

Results were presented as mean \pm SEM and $p<0.05$ as assessed by the analysis of variance followed by the Newman-Keuls test was considered significant. 


\section{Results}

\subsection{Characterisation of the arthritis induced by the intraarticular injection of BjV}

The intraarticular injection of $\mathrm{BjV}(1-32 \mu \mathrm{g} / \mathrm{ml})$ dose-dependently increased both the leukocyte accumulation and the protein leakage into the synovial fluid as measured at the 4 th $\mathrm{h}$ after the venom administration (Fig. la). The leukocyte infiltration was mainly due to polymorphonuclear cells (Fig. 1a). A higher dose $(64 \mu \mathrm{g})$ did not further increase leukocyte accumulation or protein leakage and evoked erythrocyte contamination (not shown). The intraarticular injection of $\mathrm{BjV}$ $(16 \mu \mathrm{g})$ led to a time dependent increase in the cellular infiltrate and protein leakage that was maximal at the 4 th $\mathrm{h}$, decreasing thereafter until $48 \mathrm{~h}$, when it was abolished (Fig. 1b).

\subsection{Effects of NOs inhibition and bradykinin antagonism}

L-NAME given either acutely or chronically significantly reduced leukocyte accumulation (Fig. 2a) and protein leakage (Fig. 2b) as measured at the 4th $\mathrm{h}$ after arthritis induction. Chronic administration of the inactive enantiomer DNAME had no effect on these parameters as compared to control animals, which drank only water (not shown). The previous administration of HOE 140 (0.3 mg/ $\mathrm{kg}$ ) promoted a reduction of cellular migration and protein leakage to the inflamed area at the 4 th hour of arthritis. The magnitude of this inhibitory effect on both parameters was similar to that evoked by L-NAME treatment (Fig. 2a and b).

\section{3. $\mathrm{NO}_{2} / \mathrm{NO}_{3} \cdot$ measurement in the synovial fluid}

The level of total $\mathrm{NO}_{2} \cdot \mathrm{NO}_{3}$, at the 4th hour of arthritis, was significantly reduced in the synovial fluid, collected from the $\mathrm{BjV}$ injected joint, of L-NAME and HOE 140 treated animals when compared with the level obtained in the control animals (Table 1). The $\mathrm{NO}_{2} / \mathrm{NO}_{3}$ levels in the contralateral joint, injected

Table 1

$\mathrm{NO}_{2} / \mathrm{NO}_{3}$ levels in the synovial fluid of Control, L-NAME and HOE 140 treated animals at 4 th $\mathrm{h}$ of $\mathrm{BjV}(16 \mu \mathrm{g})$ arthritis induction. The contralateral joint was injected with the same amount of BSA

\begin{tabular}{lclll}
\hline Treatment & $\begin{array}{l}\text { Control } \\
(n=4)\end{array}$ & $\begin{array}{l}\text { L-NAME } \\
(n=5) \text { Chronic }\end{array}$ & $\begin{array}{l}\text { L-NAME } \\
(n=4) \text { Acute }\end{array}$ & $\begin{array}{l}\text { HOE I40 } \\
(n=4)\end{array}$ \\
\hline $\mathrm{BjV} \mathrm{NO} / \mathrm{NO}_{3}(\mu \mathrm{M})$ & $18.08 \pm 3.05$ & $9.63 \pm 2.03^{*}$ & $9.8 \pm 2.0^{*}$ & $\begin{array}{l}5.75 \pm 3.59^{*} \\
\left.\mathrm{BSA} \mathrm{NO} \mathrm{NO}_{2} / \mu \mathrm{NO}\right)\end{array}$ \\
\hline
\end{tabular}

${ }^{*} p<0.05$ compared with values obtained of $\mathrm{BjV}$ injected joint in control animals. 


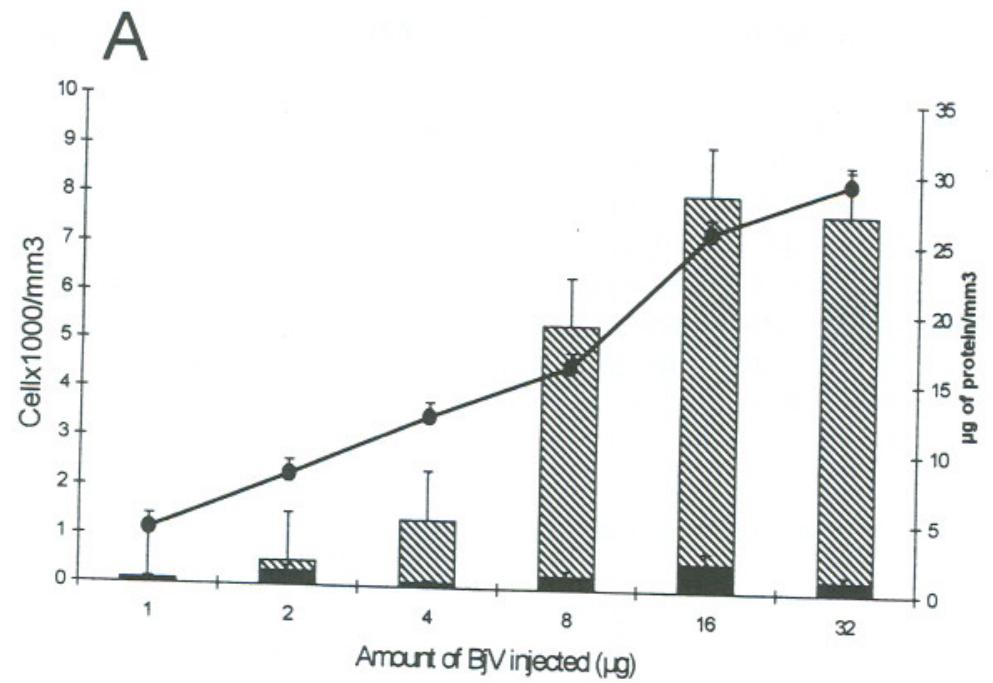

B

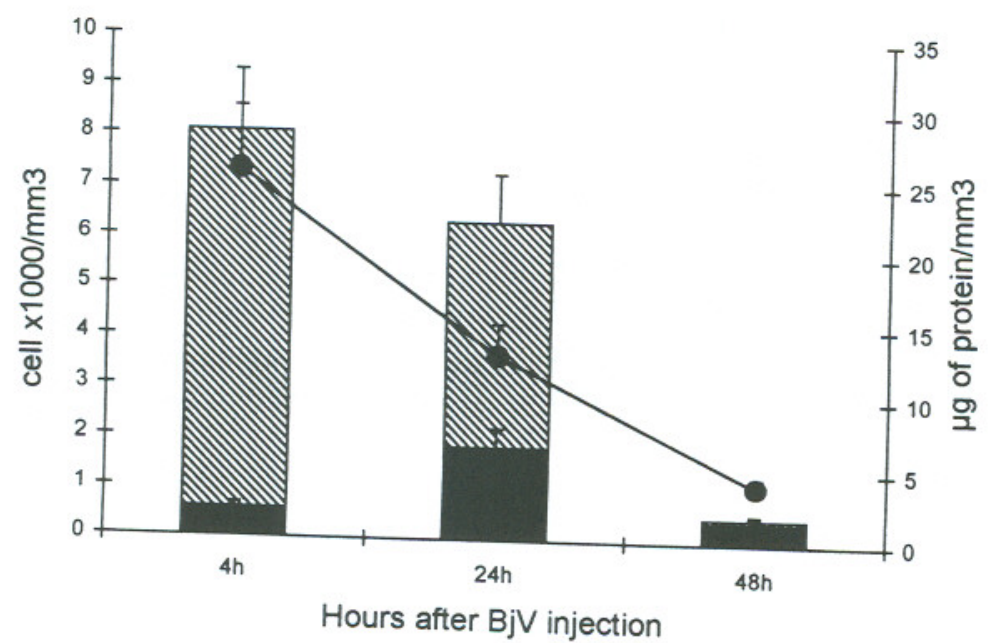

Fig. 1. Characterisation of the arthritis induced by Bothrops jararaca venom in rabbits. (a) Dose dependent cellular influx ( $\mathbf{B}=$ polymorphonuclear; $\mathbf{\square = m o n o n u c l e a r )}$ and protein leakage (line) induced Represents the intraarticularly. The animals were killed after $4 \mathrm{~h}$ of the induction of arthritis. (b) of sterile saline. The anime of the arthritis induced by the injection of $16 \mu \mathrm{g}$ of the BjV diluted in $0.5 \mathrm{ml}$ the mean \pm SEM of $4-8$ rabbits. 

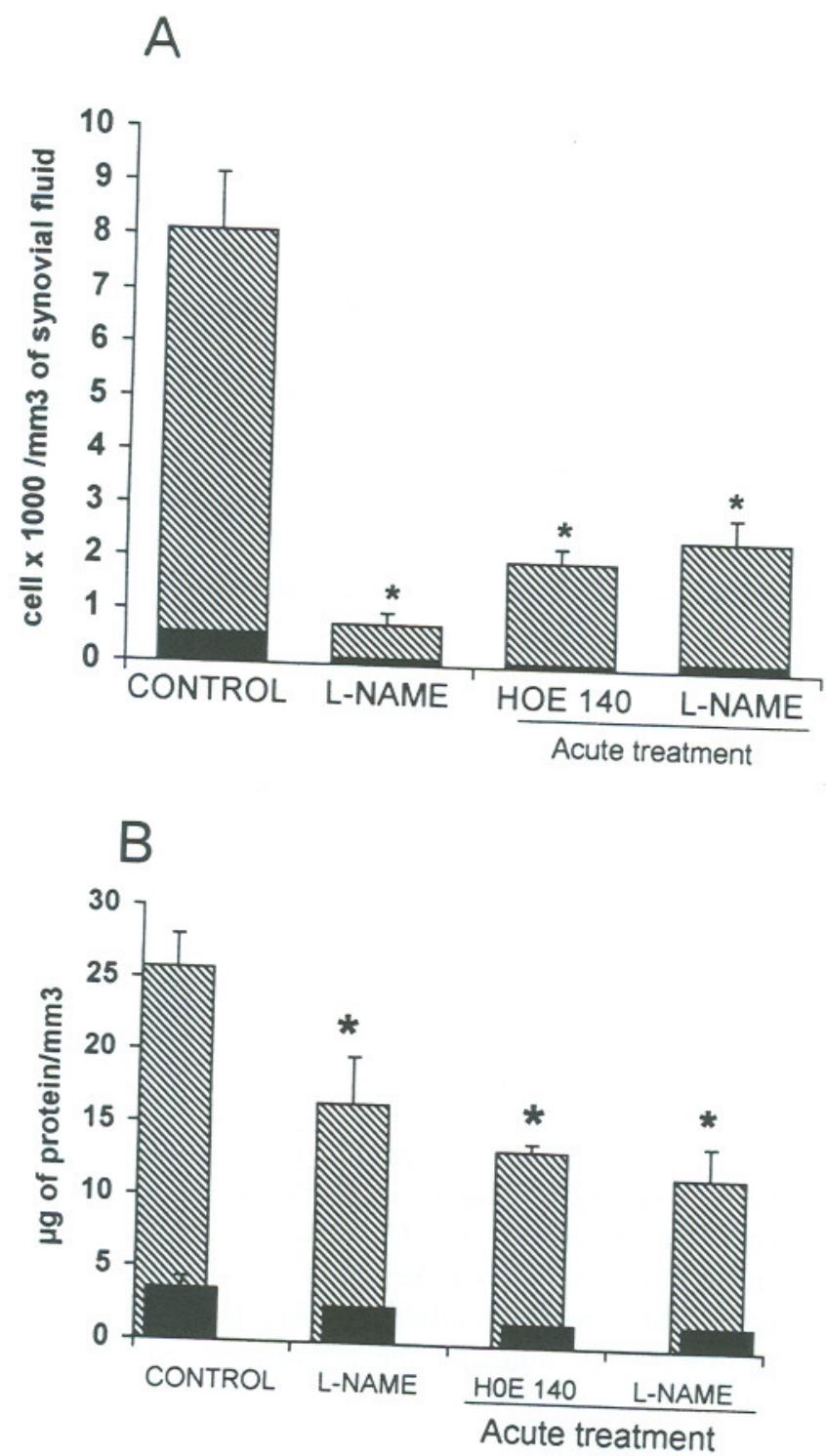

Fig. 2. (a) Total and differential cell count $(\mathbb{Q}=\mathrm{PMN}$ with $\operatorname{BjV}(16 \mu \mathrm{g}) 4 \mathrm{~h}$ after challenge. Animald of rabbits injected $\mathrm{mg} / \mathrm{kg}$ i.v.) treated with L-NAME or with were chronically $(20 \mathrm{mg} / \mathrm{kg} /$ day $/ 2$ weeks) or acutely ( 30 induction). Each column comparison with control animals. (b) Vascun \pm SEM of 4-6 joints injected with BjV. " $p<0.001$ by $4 \mathrm{~h}$ of $\mathrm{BjV}$ induced artelit collected from rabbits at $4 \mathrm{~h}$ of $\mathrm{BjV}$ induced arthritis (striped columns). The solid column represents the protein leakage assessed respective controls. 
with BSA did not differ from those evoked by saline injection (Verissimo de Mello, 1997) and were not altered by the any drug employed. Treatment with DNAME did not affect the synovial fluid levels of NO metabolites, when compared with the results obtained in animals, which drank only water (data not shown). Interestingly, the decrease in $\mathrm{NO}_{2}$ and $\mathrm{NO}_{3}$ levels observed with $\mathrm{HOE} 140$ was significantly larger as compared to that induced by the chronic L-NAME treatment.

\subsection{Synovial membrane PMN cell infiltrate}

The synovial membrane of animals that received the venom intraarticularly had significant PMN cell infiltrate at the 4th hour, 12 cells $/ 23 \mu \mathrm{m}^{2}$ (Fig. 3a). Chronic administration of L-NAME, but not D-NAME, greatly reduced the cell infiltration in the synovial membrane, 2 cells $/ 23 \mu \mathrm{m}^{2}$ (Fig. $3 \mathrm{~b}$ ). The pattern of the synovial membrane of HOE 140 treated animals was similar to that observed in the synovial membrane of the L-NAME treated animals (data not shown).

\section{Discussion}

The findings that HOE 140 and L-NAME treatment abolished the inflammatory reaction induced by $\mathrm{BjV}$ clearly implicates kinins and $\mathrm{NO}$ in this phenomenon. Since bradykinin is known to release NO from various cells, including polymorphonuclear cells (Catz and Sterin-Speziale, 1996), it could be concluded that this kinin plays a pivotal role in the venom-induced arthritis.

Other mediators, such as histamine, 5-hydroxytryptamine, PAF, cyclooxygenase and lypooxygenase products have been considered to play a role in the BjVinduced inflammatory process. The contribution of eicosanoids is relevant to oedema formation and leukocyte recruitment during BjV-induced pleurisy and airpouch inflammatory reaction (Búrigo et al., 1996; Farsky et al., 1997). Since bradykinin causes eicosanoid release via both phospholipase $\mathrm{A}_{2}$ (Hong and Deykin, 1982) and phospholipase C (De Nucci et al., 1988) activation, it is possible that bradykinin also plays a key role on eicosanoids mediation during $\mathrm{BjV}$ envenomation. Additionally, bradykinin may be responsible for $\mathrm{NO}$ release (De Nucci et al., 1988) which suggests the importance of the interaction between both mediators in the $\mathrm{BjV}$ inflammatory response. The intense reduction of $\mathrm{NO}_{2} /$ $\mathrm{NO}_{3}$ levels in the synovial fluid by HOE 140 and L-NAME suggests that NO production in the $\mathrm{BjV}$ inflammatory reaction is mediated by bradykinin.

The role of $\mathrm{NO}$ as a mediator of inflammatory reaction is controversial. The participation of $\mathrm{NO}$ in the vascular and cellular aspects of inflammation was demonstrated by their attenuation in L-NAME treated animals (Salvemini et al., 1995; Veríssimo de Mello et al., 1997; Stefanovic-Racic et al., 1995; Ianaro et al., 1994; Salvemini et al., 1996). Acute administration of L-NAME reduces protein leakage in response to different inflammatory agents; however, this reduction was attributed to a reduction in local microvascular blood flow rather than vascular 

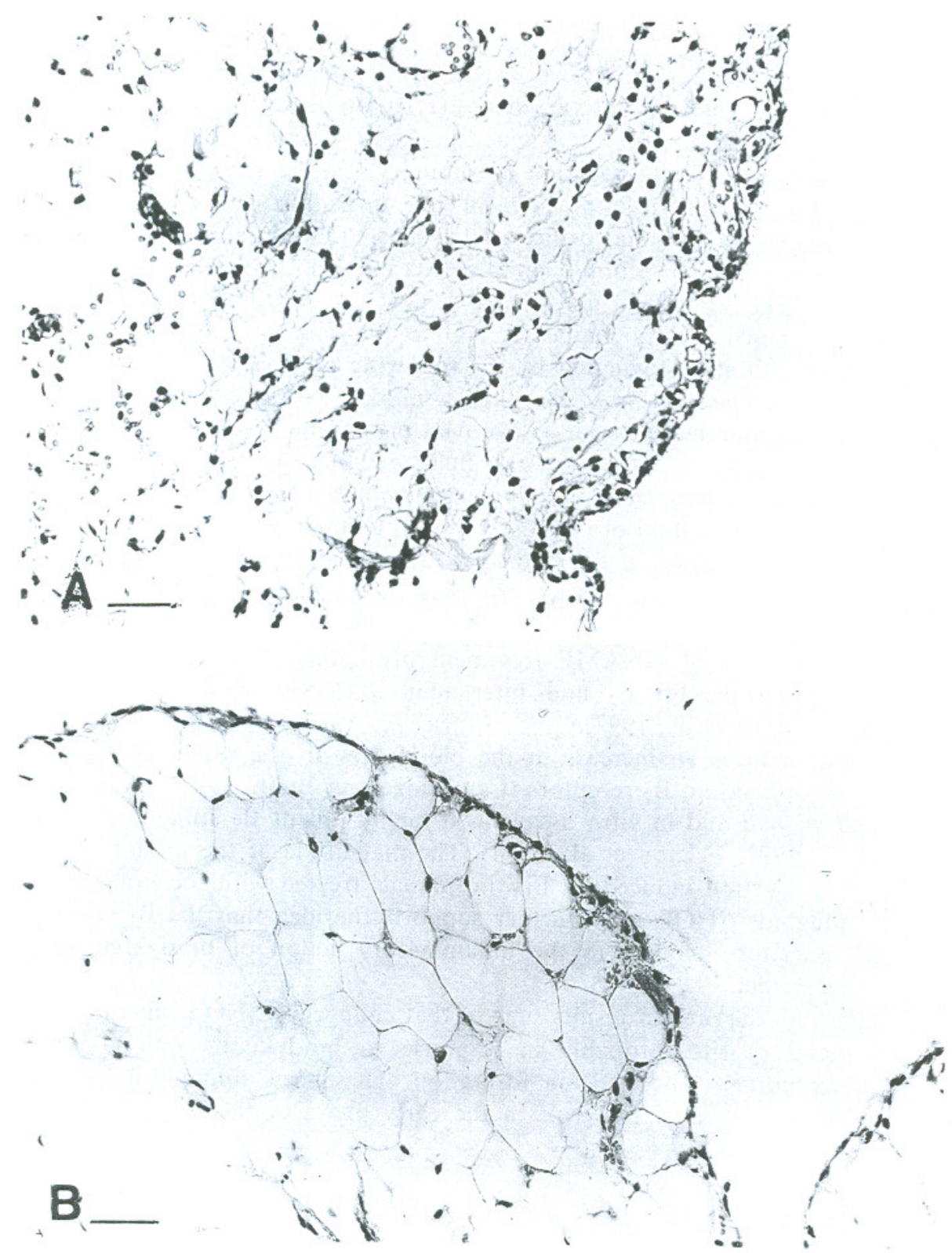

Fig. 3. Histopathological characteristics of rabhit synovial membrane at th h after BjV injection. The anmals were treated before the induction of arthritis with 1)-NAME (a) or L-NAME (b). Note the reduction of PMN cell infiltration in $\mathrm{B}$ (hatr $-2.3 \mu \mathrm{m}$ ). 
permeability (Hughes et al.. 1990; Ialenti et al., 1992; Teixeira et al., 1993; Mariani-Pedroso et al., 1995). Interestingly, L-NAME treatment increases the plasma protein influx in certain microcirculatory beds including rat large airways, liver, spleen, pancreas, kidney, stomach, duodenum, mesenteric circulation. coronary circulation and mesenteric venules (Filep and Foldes-Filep, 1993; Kurose et al., 1993). The inhibition of oriented leukocyte locomotion induced by LNMMA is overcome by L -arginine or dibutyryl cGMP (Kaplan et al., 1989), indicating an important role of $\mathrm{NO}$ on cell migration. On the other hand. intravital microscopy study has demonstrated that NOS inhibitors greatly enhance leukocyte-endothelial interactions, initial events involved in leukocyte recruitment (Kubes et al., 1991).

The present study clearly implicates $\mathrm{NO}$ in the acute phase of $\mathrm{Bj} V$ induced arthritis in the rabbit as suggested by the following observations: first, treatment with the NOS inhibitor L-NAME evoked a marked reduction in some signs of acute articular inflammation such as synovial membrane PMN cell infiltrate and vascular permeability in the synovial fluid; second, a reduction in cellular infiltration was also observed in the synovial membrane; third, $\mathrm{NO}_{2} / \mathrm{NO}_{3}$ level was reduced in the synovial fluid of L-NAME treated animals. D-NAME treatment did not induce any attenuation of the studied parameters. Our results show that in the articular environment $\mathrm{NO}$ seems to play a pro-inflammatory effect and corroborate our previous results in the antigen-induced arthritis in rabbits. These data show the effect of L-NAME treatment promoting a decrease in leukocyte infiltration, prostaglandin $E_{2}$ and interleukin-1 $\beta$ levels in the synovial fluid (Verissimo de Mello et al., 1997).

Bradykinin induces an increase in the blood flow in the rabbit synovium via activation of bradykinin $B_{2}$ receptors (Cambridge and Brain, 1998). HOE 140 has been tested in vivo and in vitro assays as a highly potent $\mathrm{B}_{2}$ antagonist receptor (Wirth et al., 1991; Feletou et al., 1994). The magnitude of the inhibition of the inflammatory reaction induced by $\mathrm{BjV}$ in animals treated with the bradykinin $\mathrm{B}_{2}$ receptor antagonist (HOE 140), further supports the idea that the $B_{2}$ receptor is the major receptor involved in the inflammatory action of bradykinin in this experimental model.

In conclusion, the present results suggest that endogenous NO is liberated at the $\mathrm{BjV}$ inflammatory site, probably in response to bradykinin, with consequent leukocyte recruitment and oedema formation. These new findings indicate that these mediators play a pivotal role in the early phase of the BjV inflammatory process.

\section{Acknowledgements}

We thank Maria de Fatima de Almeida for technical assistance and Maria Lucia Martins for $\mathrm{NO}_{2} / \mathrm{NO}_{3}$ determination. This work was partially supported by FAPESP grants and the Brazilian Society of Rheumatology (Conselho de fundos remanescentes). 


\section{References}

Bhoola, K.D., Figueroa, C.D., Worthy, K., 1992. Bioregulation of kinins: Kallikreins, kininogens and kininases. Pharmac. Rev. 44, 1-80.

Brenner, N.J., Stonesifer, G.Y., Scneck, K.A., Burns, H.D., Ransom, R.W., 1993. [125I] PIP HOE 140. a high affinity radioligand for bradykinin B2 receptors. Life Sci. 53, 1879-1886.

Búrigo, A.C., Calixto, J.B., Medeiros, Y.S., 1996. Pharmacological profile of rat pleurisy induced by Bothrops jararaca venom. J. Pharm. Pharmac. 48, 106-111.

Cambridge, H., Brain, S.D., 1998. Kinin B2 and B1 receptor-mediated vasoactive effects in rabbit synovium. Peptides 19, 569-576.

Catz, S.D., Sterin-Speziale, N.B., 1996. Bradykinin stimulates phosphoinositide turnover and phospholipase C but not phospholipase D and NADPH oxidase in human neutrophils. J. Leukocyte Biol. 59, 591-597.

Corbett, J.A., Kwon, G., Turk, J., McDaniel, M.L., 1993. IL-1 beta induces coexpression of both nitric oxide synthase and cyclooxygenase by islets of Langerhans: activation of cyclooxygenase by nitric oxide. Biochemistry 32, 13,767-13,770.

De Nucci, G., Gryglewski, R.J., Warner, T.D., Vane, J.R., 1988. Receptor mediated release of endothelium-derived relaxing factor and prostacyclin from and bovine aortic endothelial cells is coupled. Proc. Natl. Acad. Sci. USA 85, 9797-9800.

Farsky, S.H.P., Costa-Cruz, J.W.M., Cury, Y., Teixeira, C.F.P., 1997. Leukocyte response induced by Bothrops jararaca venom. Studies in vivo and in vitro. Toxicon 35, 185-193.

Feletou, M., Germain. M., Thurieau, C., Fauchere, J.L., Canet, E., 1994. Agonistic and antagonistic properties of the bradykinin B2 receptor antagonist. HOE 140, in isolated blood vessels from different species. Br. J. Pharmacol. 112, 683-689.

Filep, J.G., Foldes-Filep, E., 1993. Modulation by nitric oxide of platelet-activating factor-induced albumin extravazation in the conscious rat. Br. J. Pharmac. 110, 1347-1352.

Grabowski. P.S., Macpherson, H., Ralston, S.H., 1996. Nitric oxide production in cells derived from the human joint. Br. J. Rheumatol. 35, 207-212.

Gutiérrez. J.M., Lomonte. B.. 1989. Local tissue damage induced by Bothrops snake venoms. A review. Mem. Inst. Butantan. 51, 211-233

Hong, S.L., Deykin. D.. 1982. Activation of phospholipase A2 and C in pig aortic endothelial cells sinthesizing prostacyclin. J. Biol. Chem. 257, 7151-7156.

Hughes, S.R.. Williams, T.J., Brain, S.D., 1990. Evidence that endogenous nitric oxide modulates oedema formation induced by substance P. Eur. J. Pharmac. 191, 481-484

Ialenti, A., Ianaro, A., Moncada, S., Di Rosa, M., 1992. Modulation of acute inflammatory by endogenous nitric oxide. Eur. J. Pharmac. 211, 177-182.

Ianaro, A., O'Donnell, C.A., Di Rosa, M.. Liew. F.Y.. 1994. A nitric oxide synthase inhibitor reduces inflammation, down-regulates inflammatory cytokines, and enhances interleukin-10 production in carrageenin-induced oedema in mice. Immunology 82, 370-375.

Kaplan, S.S., Billiar, T., Curran, R.D., Zdziarski, U.E., Simmons, R.L., Basford. R.E., 1989. Inhibition of chemotaxis with NG-monomethyl-L-arginine: a role for cyclic GMP. Blood 74, 1885-1887.

Kubes, P., Suzuki, M., Granger, D.N., 1991. Nitric oxide: an endogenous modulator of leukocyte adhesion. Proc. Natl. Acad. Sci. USA 88, 4651-4655.

Kurose, I., Kubes, P., Wolf, R.. Anderson, D.C., Paulson, J., Miyasaka, M., Granger. D.N., 1993. Inhibition of nitric oxide production. Mechanism of vascular albumin leakage. Circ. Res. 73, 164 171 .

McCartney-Francis, N., Allen, J.B., Mizel, D.E., Abina, J.E., Xie. Q.W., Nathan. C.F., Wahl, S.M.. 1993. Suppression of arthritis by an inhibitor of nitric oxide synthase. J. Exp. Med. 178, 749-754.

Mariani-Pedroso. S.R.. Bizeto, L.. Antunes, E., Zatz. R., de Nucci, G.. 1995. Dissimilarity between prostaglandin El and nitric oxide donors as a potentiators of plasma exudation in the rabbit skin in vivo. Prostaglandins Leukotrienes Essent. Fatty Acids 52, $399-402$.

Muscará, M.N.. De Nucci, G.. 1996. Simultaneous determination of nitrite and nitrate anions in 
plasma, urine and cell culture supernatants by high-performance liquid chromatography with postcolumn reactions. J. Cromatogr. B. Biomed. Appl. 686, 157-164.

Novaes, G.S., Mello, S.B.V., Laurindo, I.M.M., Palacios, F.A.S., Cossermelli. W., 1997. Intraarticular nitric oxide levels in patients with rheumatoid arthritis. Rev. Hosp. Clin. Fac. Med. SP 52, 55-59.

Palmer, R.M., Hickery, M.S., Charles, I.G., Moncada, S., Bayliss, M.T., 1993. Induction of nitric oxide synthase in human condrocytes. Biochem. Biophys. Res. Commun. 193, 398-405.

Radomski, M.W., Palmer, R.M., Moncada. S., 1990. Glucocorticoids inhibit the expression of inducible, but not the constitutive nitric oxide synthase in vascular endothelial cells. Proc. Natl. Acad. Sci. USA 87, 10,043-10,047.

Rhaleb, N.E., Rouissi. N.. Jukic, D., Regoli, D., Henke, S., Breipohl, G., Knolle, J., 1992. Pharmacological characterization of a new highly potent B2 receptor antagonist (Hoe 140: D-Arg$\left[\mathrm{Hyp}^{3}, \mathrm{Thi}^{5}, \mathrm{Dtic}^{5}, \mathrm{Oic}^{8}\right]$-bradykinin). Eur. J. Pharmac. 14, 115-120.

Rocha e Silva, M., Beraldo, W.T.. Rosenfeld. G., 1949. Bradykinin, a hypotensive and smooth muscle stimulating factor released from plasma globulin by snake venoms and by trypsin. Am. J. Physiol. 156. 261-273.

Rosenfeld, G., 1971. Symptomathology, pathology and treatment of snakes bites in South America. In: Bücherl. W., Buckley, E. (Eds.). Venomous animals and their venoms, vol. 2. Academic Press. New York, p. 345 .

Salvemini, D., Misko, T.P., Masferrer, J.L., Seibert, K., Currie, M.G., Needleman, P.. 1993. Nitric oxide activates cyclooxygenase enzymes. Proc. Natl. Acad. Sci. USA I (90), 7240-7244.

Salvemini, D., Settle, S.L., Masferrer, J.L., Seibert, K., Currie, M.G., Needleman, P., 1995. Regulation of prostaglandin production by nitric oxide: an in vivo analysis. Br. J. Pharmac. 114, 1171-1178.

Salvemini, D., Wang, Z.Q., Wyatt, P.S., Bourdon, D.M., Marino, M.H., Manning, P.T., Currie, M.G., 1996. Nitric oxide: a key mediator in the early and late phase of carageenan-induced rat paw inflammation. Br. J. Pharmac. 118, 829-838.

St Clair, E.W.. Wilkinson, W.E., Lang. T., Sanders, L., Misukonis, M.A., Gilkeson, G.S., Pisetsky, D.S.. Granger, D.I., Weinberg. J.B., 1996. Increased expression of blood mononuclear cell nitric oxide synthase type 2 in rheumatoid arthritis patients. J. Exp. Med. 184, 1173-1178.

Stadler, R.J., Stefanovic-Racic, M., Billiar. T.R.. Curran, R.D., McIntyre, L.A., Georgescu. H.I.. Simmons, R.L., Evans, C.H., 1991. Articular condrocytes synthesize nitric oxide in response to cytokines and lipopolysaccharide. J. Immun. 147, 3915-3920.

Stefanovic-Racic, M., Stadler, J., Georgescu, H.I., Evans, C.H., 1994a. Nitric oxide and energy production in articular chondrocytes. J. Cell. Physiol. 159, 274-280.

Stefanovic-Racic. M., Stadler, J., Georgescu, H.I., Evans, C.H., 1994b. Nitric oxide synthesis and its regulation by rabbit synoviocytes. J. Rheumat. 21, 1892-1898.

Stefanovic-Racic, M., Meyers, K., Meschter, C., Coffey, J.W., Hoffman, R.A., Evans, C.H.. 1994c. NMonomethyl arginine, an inhibitor of nitric oxide synthase, suppresses the development of adjuvant arthritis in rats. Arthritis Rheum. 37, 1062-1069.

Stefanovic-Racic. M., Meyers, K., Meschterm. C.. Coffey, J.W., Hoffman, R.A., Evans, C.H., 1995. Comparison of the nitric oxide synthase inhibitors methylarginine and aminoguanidine as prophylactic and therapeutic agents in rat adjuvant arthritis. J. Rheumat. 22, 1922-1928.

Teixeira, M.M., Williams. T.J., Hellewell, P.G., 1993. Role of prostaglandin and nitric oxide in acute inflammatory reaction in guinea-pig skin. Br. J. Pharmac. 110, 1515-1521.

Trebien. H.A.. Calixto, J.B., 1989. Pharmacological evaluation of rat paw oedema induced by Bothrops jararaca venom. Agents Actions 26, 292-300.

Verissimo de Mello, S.B.. Novaes, G.S., Laurindo. I.M.M., Maciel. F.M.B., Cossermelli. W., 1997. NOs inhibition influences eicosanoids and interleukin I production in experimental arthritic joint. Inflamm. Res. 46, 72-77.

Wirth. K., Hock, F.J., Albus, U., Linz, W., Alpermann, H.G., Anagnostopoulos, H., Henk. S., Breipohl, G., Konig. W.. Knolle, J., et al., 1991. Hoe 140 a new potent and long acting bradykininantagonist: in vivo studies. Br. J. Pharmac. 102, 774-777. 
Anexo 4. Trabalho apresentado: VERÍSSIMO DE MELLO, S.B.; GUZZO, M.L.; LISBOA, L.F.S.; 93 FARSKY, S.H.P. Pharmacological characterization of arthritis induced by Bothrops jararaca venom in rabbits. A positive cross-talk between bradykinin, nitric oxide and Prostaglandin E2 (BjV). Mediators of Inflammation $11(1): 13-6,2002$.

BACKGROUND: Our previous results showed that nitric oxide (NO) and bradykinin (BK) mediate the arthritis induced by Botbrops jararaca venom (BjV) in rabbits. In this study, we investigated the contribution of each receptor of $\mathrm{BK}$ as well as the inter-relationship between NO and eicosanoids in BjV-induced arthritis.

Metbods: The arthritis was induced in rabbits with $16 \mu \mathrm{g}$ of $\mathrm{BjV}$ injected intra-articularly. Prostaglandin $\mathrm{E}_{2}\left(\mathrm{PGE}_{2}\right)$, thromboxane $\mathrm{B}_{2}\left(\mathrm{TxB}_{2}\right)$, leukotriene $\mathrm{B}_{4}$ $\left(\mathrm{LTB}_{4}\right)$ (radioimmunoassay) and nitrite/nitrate concentrations $\left(\mathrm{NO}_{2} / \mathrm{NO}_{3}\right)$ (Griess reaction) were evaluated in the synovial fluid $4 \mathrm{~h}$ later. The animals were prior treated with NO synthase inhibitor (L-NAME; $20 \mathrm{mg} / \mathrm{kg} /$ day for 14 days), the B2 antagonist of BK (HOE-140) and the B1 antagonist of BK (des$\mathrm{Arg}^{9}\left[\mathrm{Leu}^{8}\right]$-bradykinin), both at a dose of $0.3 \mathrm{mg} / \mathrm{kg}$, $30 \mathrm{~min}$ prior to the venom injection.

Results: Data show that L-NAME and HOE-140 treatment were equally able to reduce $\mathrm{PGE}_{2}$ and $\mathrm{NO}_{2} / \mathrm{NO}_{3}$ levels without interfering with $\mathrm{TxB}_{2}$ and $\mathrm{LTB}_{4}$ production. On the contrary, the B1 antagonist of BK inhibited $\mathrm{TxB}_{2}$ and $\mathrm{LTB}_{4}$ production, and did not alter $\mathrm{PGE}_{2}$ and NO metabolites levels in the inflamed joint.

Discussions: The results presented clarify the contribution of the kinin system, mainly through the B2 receptor, to the local inflammatory response induced by $\mathrm{BjV}$, as well as its positive interaction with $\mathrm{PGE}_{2}$ and NO production.

Key words: Bothrops jararaca venom, Inflammatory reaction, Arthritis, Bradykinin, Nitric oxide, Eicosanoids

\section{Pharmacological characterisation of arthritis induced by Bothrops jararaca venom in rabbits: a positive cross talk between bradykinin, nitric oxide and prostaglandin $\mathrm{E}_{2}$}

Suzana B. V. Mello ${ }^{1, C A}$, Maria Luiza Guzzo', Luiz Filipe Santiago Lisboa ${ }^{1}$ and Sandra H. P. Farsky ${ }^{2}$

${ }^{1}$ Rheumatology Division, Department of Internal Medicine, School of Medicine, University of São Paulo, Av. Dr. Arnaldo 455, Sāo Paulo 0124-6903, SP, Brazil; ${ }^{2}$ Laboratory of Imunochemistry, Instituto Butantan, Av. Vital Brazil 1500, São Paulo 05503-900, SP, Brazil

\footnotetext{
${ }^{\mathrm{CA}}$ Corresponding Author

Tel: +551130667492

Fax: +551130667490

E-mail: svmello@usp.br
}

\section{Introduction}

Endogenous nitric oxide (NO) has been described as a pro-inflammatory molecule showing interactions with cytokines ${ }^{1-3}$ and inflammatory products of the cyclooxygenase pathway. ${ }^{4-10}$ Studies have shown that NO increases interleukin-1 $\beta$ and eicosanoid products, which may result in an exacerbated inflammatory response. ${ }^{2.3}$ In addition, inhibition of NO biosynthesis by an L-arginine antagonist reduced prostaglandin $\mathrm{E}_{2}$ $\left(P E_{2}\right)$ production in different models of inflammatory reactions in vivo. ${ }^{11-13}$

Additionally, bradykinin (BK) and NO have been implicated on eicosanoids and cytokine secretions in several experimental inflammatory processes. ${ }^{8,12,13-15}$ BK acts on the acid arachidonic metabolism via both phospholipase $\mathrm{A}_{2}{ }^{16}$ and phospholipase $\mathrm{C}^{17}$ activation. Also, BK is known to release NO from various cells, including polymorphonuclear ${ }^{18}$ and endothelial cells at the site of injury. ${ }^{19}$

The acute inflammatory reaction induced by Bothrops jararaca venom $(\mathrm{BjV})$ is determined by oedema and leukocyte influx. ${ }^{20-22}$ These effects are mediated by histamine, serotonine, products of arachidonic acid metabolism, platelet-activating factor and factors derived from complement system. ${ }^{20-22}$ The eicosanoids contribution is relevant to oedema formation and leukocyte recruitment during $\mathrm{BjV}$ induced pleurisy and air-pouch inflammatory reaction. $^{21,22}$ Recently, to determine the participation of kinins and $\mathrm{NO}$ in the local inflammatory reaction induced by $\mathrm{BjV}$, we developed an experimental model of arthritis by injecting the venom intra-articularly. The findings that B2 BK antagonist (HOE-140) and $\mathrm{NO}$ synthase inhibitor (L-NAME) treatment greatly reduced the cellular influx and protein leakage in the arthritis induced by $\mathrm{BjV}$ clearly implicate kinins and $\mathrm{NO}$ in this phenomenon. ${ }^{23}$

Since eicosanoids, BK and NO are important mediators involved in the inflammatory reaction evoked by $\mathrm{BjV}$, and since there is strong evidence regarding the interaction between these mediators on different models of the inflammatory process, the aim of this study was to evaluate the participation of each receptor of $\mathrm{BK}$ in $\mathrm{NO}$ and eicosanoid production in the acute inflammatory response evoked by $\mathrm{BjV}$. 


\section{Material and methods}

Induction of arthritis

The Animal Ethics Committee of COBEA (Brazilian College of Experimental Animals) approved all experimental procedures, performed on animals in accordance with procedures set by The Universities Federation for Animals Welfare. The arthritis was induced in the knee joint of Male New Zealand White rabbits $(2 \mathrm{~kg})$ by the injection of $\mathrm{BjV}$ provided by the Laboratory of Herpetology, Butantan Institute, Brazil ( $16 \mu \mathrm{g}$ diluted in $0.5 \mathrm{ml}$ of saline). The venom was filtered in sterilising membrane (ester cellulose filter, $0.22 \mu \mathrm{m}$ pore size; Millipore, Săo Paolo, Brazil) before joint injection. The contralateral joint was injected with the same amount of bovine serum albumin (BSA) (Sigma, St Louis, MO, USA). The amount of protein present in BjV or BSA solution was spectrophotometrically assessed and the equivalent protein concentration was injected in each joint. Four hours after intraarticular challenge, the animal was anaesthetised with a mixture of xylazine $(5 \mathrm{mg} / \mathrm{kg}$; Bayer, Săo Paolo, Brazil) associated with ketamine $(50 \mathrm{mg} / \mathrm{kg}$; Parke Davis, Săo Paolo, Brazil) by intramuscular injection and killed by intravenous injection of $2.0 \mathrm{ml}$ of $20 \%$ $\mathrm{KCl}$ solution. Immediately after the sacrifice, $2 \mathrm{ml}$ of saline containing ethylenediamine tetraacetic acid $(1 \mathrm{mg} / \mathrm{ml})$ was injected into the knee joint. Synovial fluid was aspirated, the joint was opened and the remainder of the synovial fluid was recovered and stored at $-70^{\circ} \mathrm{C}$.

\section{Pharmacological treatments}

A group of animals were randomly treated with L-NAME (Sigma), $20 \mathrm{mg} / \mathrm{kg} /$ day mixed with drinking water, administered for 2 weeks prior to the induction of arthritis. Treatments with $0.3 \mathrm{mg} / \mathrm{kg}$ of B1 or B2 BK antagonists des-Arg ${ }^{9}\left[\mathrm{Leu}^{8}\right]$-bradykinin (Sigma) and HOE-140 (Hoechst, Frankfurt, Germany), respectively, were performed subcutaneously, $30 \mathrm{~min}$ before the venom injection. Control animals received an equivalent volume of sterile saline by the same route.

\section{Determination of total $\mathrm{NO}_{2} \cdot / \mathrm{NO}_{3}$. levels in the} synovial fluid

The concentration of the total amount of nitrate and nitrite $\left(\mathrm{NO}_{2} \cdot / \mathrm{NO}_{3} \cdot\right)$ anions (stable $\mathrm{NO}$ breakdown products in vivo) present in the synovial fluid samples collected $4 \mathrm{~h}$ after venom injection was determined by Griess reaction. The absorbance was monitored at $546 \mathrm{~nm}$.

\section{Determination of eicosanoids in the synovial fluid}

$\mathrm{PGE}_{2}$, thromboxane $\mathrm{B}_{2}\left(\mathrm{TxB}_{2}\right)$, leukotriene $\mathrm{B}_{4}\left(\mathrm{LTB}_{4}\right)$ levels were assayed in the synovial fluid collected $4 \mathrm{~h}$ after venom injection using commercial kits (NEN Life Science products, Boston, MA, USA) as previously described. ${ }^{24,25}$ The competitive binding radioimmunoassays were performed in polypropylene tubes with the reagents diluted in phosphate-buffered saline ( $\mathrm{pH}$ 6.8) with gelatine and thimerosal. One hundred microlitres each of unknown samples, of tracers ( ${ }^{125} \mathrm{I}_{-}-\mathrm{PGE}_{2}$ and ${ }^{125} \mathrm{I}-\mathrm{TxB}_{2}$ or ${ }^{3} \mathrm{H}-\mathrm{LTB}_{4}$ ), and of rabbit antiserum to each eicosanoids were combined and incubated overnight at $8^{\circ} \mathrm{C}$ for $\mathrm{LTB}_{4}$ determination, and were then incubated for $2 \mathrm{~h}$ at $25^{\circ} \mathrm{C}$ in a water bath for $\mathrm{PGE}_{2}$ and $\mathrm{TxB}_{2}$ determinations. Unbound radiolabelled $\mathrm{PGE}_{2}$ and $\mathrm{TxB}_{2}$ was removed by the addition of $250 \mu \mathrm{l}$ of donkey anti-rabbit serum coated onto magnetisable polymer particles, and $\mathrm{LTB}_{4}$ was removed by the addition of $250 \mu \mathrm{l}$ of $2 \%$ charcoal suspension coated with $0.4 \%$ dextran to the tubes. After centrifugation, the residual bound activity was measured in each tube by counting ${ }^{125} \mathrm{I}_{-} \mathrm{PGE}_{2}$ and ${ }^{125} \mathrm{I}-\mathrm{TxB}_{2}$ in a $\gamma$-scintillation counter, and ${ }^{3} \mathrm{H}_{-} \mathrm{LTB}_{4}$ in a $\beta$-scintillation counter. Cross-reactivities of the antiserum with other eicosanoids were below $0.05 \%$. The assay sensitivities were $1.25-160 \mathrm{pg} /$ tube $\left(\mathrm{PGE}_{2}\right)$, and $1.6-200 \mathrm{pg} /$ tube $\left(\mathrm{LTB}_{4}\right)$.

\section{Statistics}

Results are expressed as mean \pm standard error of mean. Results were analysed by Student's $t$-test or by repeated-measures analysis of variance. When appropriate, the data were analysed by the Newman-Keuls test. The chosen level of significance was 0.05 .

\section{Results}

Eicosanoids and $\mathrm{NO}_{2} \cdot / \mathrm{NO}_{3}$ levels in the synovial fluid

The synovial fluid collected from animals pre-treated with L-NAME, HOE-140 and des-Arg ${ }^{9}\left[\right.$ Leu $\left.^{8}\right]$-bradykinin and intra-articularly injected with venom, and that from respective controls, was extracted to $\mathrm{PGE}_{2}, \mathrm{LTB}_{4}$ and $\mathrm{TxB}_{2}$. The determinations were performed by radioimmunoassay. $\mathrm{NO}_{2} \cdot / \mathrm{NO}_{3}$ levels in diluted joint wash were also determined by Griess reaction. Figure $1 \mathrm{~A}$ shows the $\mathrm{PGE}_{2}$ level measured in the synovial fluid obtained $4 \mathrm{~h}$ after the BjV. Prior treatment of the rabbits with L-NAME or B2 antagonist of BK HOE-140 significantly reduced it when compared with values obtained in samples from animals, which did not receive pharmacological treatments. It is important to note that des$\operatorname{Arg}^{9} 1\left[\mathrm{eu}^{8}\right]$-bradykinin treatment did not interfere with the production of $\mathrm{PGE}_{2}$. On the contrary, levels of $\mathrm{LTB}_{4}$ and $\mathrm{TxB}_{2}$ (represented in Fig. $1 \mathrm{~B}$ and Fig. $1 \mathrm{C}$, respectively) exhibited a different pattern of alteration. They were not altered after treatment with L-NAME or HOE-140, but they were greatly reduced 
Anexo 4. Trabalho apresentado: VERÍSSIMO DE MELLO, S.B.; GUZZO, M.L.; LISBOA, L.F.S.; 95 Anexo 4. Trabalho apresentado:
FARSKY, S.H.P. Pharmacological characterization of arthritis induced by Bothrops jararaca
venom in rabbits. A positive cross-talk between bradykinin, nitric oxide and Prostaglandin E2 (BjV). Mediators of Inflammation 11 (1):13-6, 2002.

Mediators involved in arthritis induced by $B$. jararaca venom

A

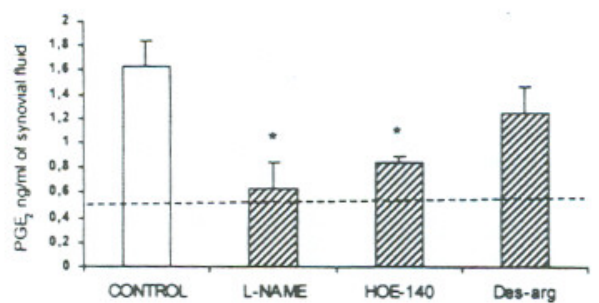

B

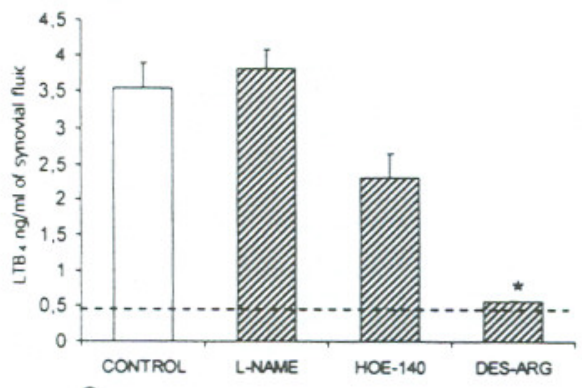

C
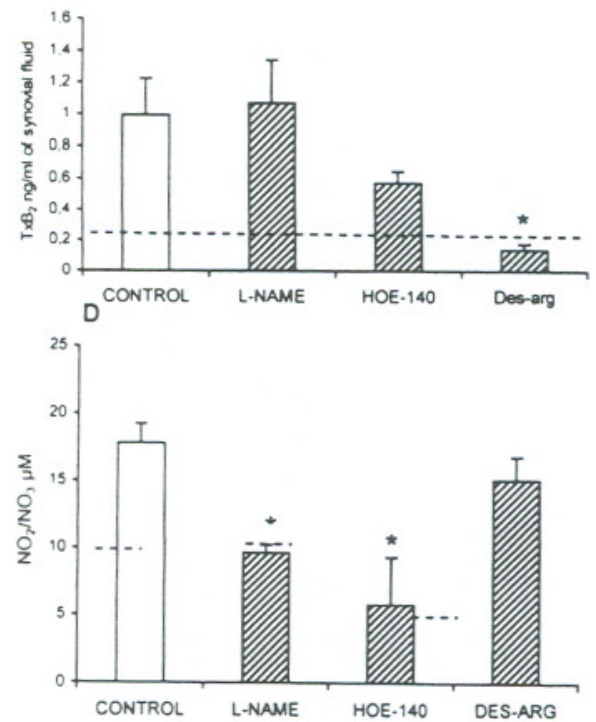

FIG. 1. Effects of L-NAME, HOE-140 and des-Arg ${ }^{9}\left[\mathrm{leu}^{8}\right]$. bradykinin treatments on local eicosanoid and NO production $4 \mathrm{~h}$ after intra-articular injection of BjV. (A) PGE $\mathrm{P}_{2}$ levels, (B) $L T B_{4}$ levels (C) $\mathrm{T}_{x B_{2}}$ levels and (D) $\mathrm{NO}_{2} / \mathrm{NO}_{3}$. levels following treatments with L-NAME $(n=5)$, HOE-140 $(n=4)$ and des-Arg ${ }^{9}\left[\right.$ Leu $\left.^{8}\right]$-bradykinin $(n=5)$. Open column, the level of the eicosanoid in control animals $(n=6)$. Dotted line, the values of each eicosanoid in the BSA-injected joint. Each column expresses data as the mean ( \pm s.e.m.). ${ }^{*} p<0.05$ by comparison with control animals.

after pre-treatment with the B1 antagonist of BK desArg $^{9}\left[\right.$ Leu $\left.^{8}\right]$-bradykinin. Also, values observed in samples from Bl antagonist-treated animals were significantly lower than that obtained in samples from control animals. At the fourth hour after the injec- tion of BSA, the contralateral joint exhibited low levels of the eicosanoids, similar to the observed in the saline-injected joint (data not shown). ${ }^{12.26}$

Similar to the observed pattern of alteration promoted in $\mathrm{PGE}_{2}$ production, the level of the total amount of the $\mathrm{NO}$ metabolites $\left(\mathrm{NO}_{2} \cdot / \mathrm{NO}_{3} \cdot ; \mathrm{Fig}\right.$. 1D) was significantly reduced in the synovial fluid collected from L-NAME-treated and HOE-140-treated animals when compared with the level observed in control animals. Differently, the treatment with the B1 antagonist of BK, des-Arg ${ }^{9}\left[\mathrm{Leu}^{8}\right]$-bradykinin, did not affect NO production in the joint, which exhibited values of $\mathrm{NO}_{2} \cdot / \mathrm{NO}_{3}$ obtained $4 \mathrm{~h}$ after $\mathrm{BjV}$ injection equivalent to those found in control animals.

\section{Discussion}

The data presented in this paper regarding $\mathrm{BjV}$ local effects corroborate the positive cross-talk between $\mathrm{BK}, \mathrm{NO}$ and the cyclooxygenase $(\mathrm{COX})$ product $\mathrm{PGE}_{2}$ described in the inflammatory reaction induced by other different agents, ${ }^{8,12,13}$ and additionally show the main participation of the B2 BK receptor in this axis. This last observation is in accordance with recent experimental studies in rats that demonstrated HOE140 treatment reduced the oedema induced by local injection of Bothrops lanceolatus snake venom and abolished the hyperalgesic effect of $\mathrm{BjV}^{27.28}$ Additionally, the employment of specific receptor antagonists and enzymatic inhibitors in experimental studies has demonstrated the participation of BK receptors and COX metabolites on the inflammatory process evoked by BjV through measurement of its symptomatic effects such as oedema, ${ }^{20.21 .29}$ leukocyte recruitment ${ }^{21,22,29}$ and pain. ${ }^{28}$ However, in the experimental model employed in this study, it was possible to establish the link between each mediator involved in the kinin/NO/COX axis at the inflammatory site after pharmacological treatments.

We have clearly demonstrated the contribution of the kinin system, via the B2 receptor, on NO production, with subsequent stimulation of $\mathrm{PGE}_{2}$ secretion. Also, our results showed that the B2 receptor and $\mathrm{NO}$ do not participate in $\mathrm{LTB}_{4}$ and $\mathrm{TXB}_{2}$ secretions, which were affected by inhibition of the B1 receptor. These conclusions are demonstrated by the following observations: (1) HOE-140 and L-NAME treatments equally abolished the inflammatory reaction, ${ }^{23} \mathrm{PGE}_{2}$ and $\mathrm{NO}_{2} / \mathrm{NO}_{3}$ levels without interfering with $\mathrm{LTB}_{4}$ or $\mathrm{TxB}_{2}$ production; and (2) alternatively, des-Arg ${ }^{9}\left[\right.$ Leu $\left.^{8}\right]$-bradykinin treatment did not alter the $\mathrm{PGE}_{2}$ and $\mathrm{NO}$ metabolites, and greatly reduced $\mathrm{LTB}_{4}$ and $\mathrm{TxB}_{2}$ secretions. It is important to note that our previous results showed that the NO synthase inhibitor (L-NAME) and the B2 receptor antagonist of BK (HOE-140) treatments promoted a great reduction of the leukocyte influx ( $90 \%$ of the control animals) to the articular cavity. ${ }^{23}$ These data associated with the 
verified low levels of $\mathrm{LTB}_{4}$ in the joint, suggest the participation of other(s) chemoattractant(s) in this phase of $\mathrm{BjV}$ inflammatory reaction. Recent experimental studies have demonstrated that Bothrops snake venoms activate the complement system, with a consequent contribution of its metabolites on leukocyte recruitment. ${ }^{22,30}$ The participation of the complement system, BK and NO has been described in several models of inflammation. ${ }^{31,32}$ The possibility that the complement system participates in or may be affected by BK/NO cascade in the bothropic envenomation will be further investigated. In addition, the treatment with the $\mathrm{B} 1$ receptor antagonist of $\mathrm{BK}$, which promoted reduction of $\mathrm{LTB}_{4}$, was less effective than $\mathrm{HOE}-140$, promoting $40 \%$ of reduction in the cellular influx to the inflamed area (data not shown).

In conclusion, our results suggest that the NO generation in arthritis induced by $\mathrm{BjV}$ is produced mainly after BK stimulation through B2 receptors. Also, the endogenous release of NO enhances COX activity with further increase of $\mathrm{PGE}_{2}$ production, demonstrating the inter-relation between the kinins system with $\mathrm{NO}$ and $\mathrm{PGE}_{2}$ in the $\mathrm{BjV}$ inflammatory process.

This paper, together our previous results, ${ }^{23}$ would be useful to pharmacological interventions to modulate the imminent inflammatory response evoked by $\mathrm{BjV}$, which is not neutralised by specific antivenom.

AC.KNOWLEDGEMENTS. The authors thank Maria de Fatima de Almeida and Maria Aurora Gomes da Silva for technical assistance. This work was supported by FAPESP grants $\$ 99 / 0149-5$.

\section{References}

1 Kelner MJ. Uglik SF. Mechanism of prostaglandin $E_{2}$ release and increase in $\mathrm{PGH}_{2} / \mathrm{PGE}_{2}$ isomerase activity by PDGF: involvement of nitric oxide. Arch Biochem Biophys 1994; 312: 240-243.

2. Inoue T, Fukuo K. Morimoto S, Koh E, Ogihara T. Nitric oxides mediates interleukin-1-induced prostaglandin $E_{2}$ production by vascular smooth muscle cells. Biochem Btophys Res Commun 1993; 194: 420-424.

3 Corbett JA, Kwon G, Turk J, MCDaniel ML. IL-1 beta induces coexpression of both nitric oxide synthase and cyclooxygenase by islets of Langer. hans: activation of cyclooxygenase by nitric oxide. Biocbemistry 1993:
32: $13767-13770$.

4 Milano S. Arcoleo F. Dieli M. D'Agostino R. D'Agostino P, De Nucci G. Cillari E. Prostaglandin $E_{2}$ regulates inducible nitric oxide synthase in the murine macrophage cell line J774. Prostaglandins 1995: 49: 105-115.

Molina HF, Ledo A. Guaza C. Evidence for cyclooxygenase activation by nitric oxide astrocyres. Glia 1995: 15: 167-172.

6. Davidge ST, Baker PN. Laughlin MK, Roberts JM. Nitric oxide produced by endothelial cells increases production of eicosanoids through activation of prostaglandin H synthase. Circ Res 1995: 77: 274-283.

activation of prostaglandin H synthase. Circ Res 1995: 77: 274-283.
7. Salvemini D. Seiber K. Masferrer $\Omega$., Misko TP, Currie MG, Needleman P Endogenous nitric oxide enhances prostaglandin production in a model of renal inflammation. J Clin Iniest 1994; 93 : 1940-1947.

8. Salvemini D. Settle SL. Masferrer JL, Seibert K. Currie MG, Needleman P. Regulation of prostaglandin production by nitric oxide: an in with anatysis. BrJ Pharmacol 1995; 114: 1171-1178.

9. Swierkosz TA. Mitchell JA, Warner TD, Botting RM, Vane JR. Co-induction of nitric oxide synthase and cycloxygenase: interactions between nitric oxide and prostanoids. BrJ Pharmacol 1995; 114: 1335-1342.
10. Tetsuka T, Dafhna-Iken D, Srivastava SK, Baier LD, DuMaine J, Morrivwon AR. Crosstalk between cyclooxygenase and nitric oxide pathways prostaglandin $E_{2}$ negatively modulates induction of nitric oxide synthase by interleukin 1. Proc Natl Acad Sct USA 1994: 91: 12168-12172.

11. Salvemini D. Misko TP, Masferrer JL, Seibert K. Currie MG, Needleman P Nitric oxide activates cyclooxygenase enzymes. Proc Natl Acad Sor USA
1993; 90: 7240-7244. 2. Verissimo de Mello SB, Novaes GS, Laurindo IMM, Maciel FMB. Cossermelli W. NOs inhibition influences eicosanoids and interleukin 1 production in experimental arthritic joint. Inflamm Res 1997; 46 $72-77$.

13. Palácios FAS, Novaes GS. Guzzo ML. Laurindo IMM. Mello SBV Interrelationship of kinin system. nitric oxide and eicosanoids in the Interrelationship of kinin system, nitric oxide and eicosanoids in the
antigen induced arthritis in rabbits. Mediat Inflamm 1999: 8 antigen $249-255$

14. McCartney-Francis N, Allen JB, Mizel DE, Abina JE, Xie QW, Nathan CF, Wahl SM. Suppression of arthritis by an inhibitor of nitric oxide synthase J Exp Med 1993: 178: 749-754

15. Taskiran D, Stefanovic-Racic M, Georgescu H, Evans $\mathrm{CH}$. Nitric oxide mediates suppression of cartilage proteoglycan synthesis by interleukin. 1. Biochem Biopbys Res Commun 1994; 200: 142-148.

16. Hong SL. Deykin D. Activation of phospholipase $A_{2}$ and $C$ in pig aoric endothelial cells synthesising prostacyclin. $J$ Biol Chem 1982:257 $7151-7156$

17. De Nucci G, Gryglewski R, Warner TD, Vane JR. Receptor mediated release of endothelium-derived relaxing factor and prostacyclin from and bovine aortic endothelial cells is coupled. Proc Natl Acad Sct 1988: 85 9797-9800.

18. Catz SD, Sterin-Speziale NB. Bradykinin stimulate phosphoinositide turnover and phosphotipase $C$ but not phospholipase $D$ and $N A D P H$ turnover and phospholipase $C$ hut not phospholipase D and
oxidase in human neutrophils. $J$ Lete Btol 1996; 59:591-597.

19. Radomski MW, Palmer RM. Moncada S. Glucocorticoids inhibit the expression of inducible, but not the constitutive nitric oxide synthase in vascular endothelial cells. Proc Natl Acad SCt USA 1990; 87 10043-10047

20. Trebien HA, Calixto JB. Pharmacological evaluation of rat paw oedema induced by Botbmos jararaca venom. Agents Actions 1989; 26 $292-300$

21. Búrigo AC, Calixto JB. Medeiros YS. Pharmacological profile of rat pleurisy induced by Bothrops jararaca venom. I Pharm Pharmacol 1996; $48: 106-111$

22. Farsky SHP. Costa-Cruz JWM. Cury Y. Teixeira CFP. Leucocyte response induced by Bothrops jararaca venom. Studies in wito and in witro. Taxicon 1997; 35 : 185-193.

23. Guzzo ML, Farsky SHP, De Nucci G, Antunes E, Silva MAG, Mello SBV Role of kinins and nitric oxide on the rabbit arthritis induced by Botbmps fararaca venom. Taxicon 2000: 38: 1535-1546

24. Salmon JA. A radioimmunoassay for (-Keto-prostaglandin F1 alfa Prostaglandins 1978: 15: 387-397.

25. Salmon JA, Simmons PM. Palmer RMJ. A radioimmunoassay for leukor triene $\mathrm{B}_{4}$. Prostaglandins 1982: $24: 225-235$.

26. Novaes GS, Mello SBV. Laurindo IMM. Cossermelli W. Low-dose methotrexate decreases intraarticular prostaglandin and interleukin.1 levels in antigen-induced arthritis in rabbits. $J$ Rbeumatol 1996: 23 2092-2097.

27. De Faria L, Antunes E, Bon C, de Araujo AL. Pharmacological character. isation of the rat paw edema induced by Botbmps lanceolatus (Fer de Lance) venom. Toxtcon 2001:39:825-830

28. Chacur M, Gutierrez JM. Teixeira C.F. Cury Y. Pharmacological modulation of hyperalgesia induced by Botbrops asper (terciopelo) snake venom Taxicon 2001: 39: 1173-1181

29. Teixeira CFP, Costa-Cruz JWM. Cury Y. Study of inflammatory events induced by Bothrops jararaca venom in the air pouch. Taxicon 1996 34: 323 .

30. Farsky SHP, Gonçalves LRC, Gutierrez JM. Correa AP. Rucavado A. Gasque P. Tambourgi DV. Botbrops asper snake venom and its metalloproteinase BaP.1 activate the complement system. Role in leucocyte recruitment. Mediat Inflamm 2000; 9: 213-221

31. Gryglewski RJ, Chlopicki S, Uracz W, Marcinkiewicz E. Significance of endothelial prostacyclin and nitric oxide in peripheral and pulmonary circulation. Med Sct Monit 2001; 7: 1-16.

32. Ogino M, Majima M, Kawamura M. Hatanaka K, Saito M. Harada Y, Katori M. Increased migration of neutrophils to granulocyte-colony stimulating factor in rat carrageenin-induced pleurisy: roles of complement, bradyki-

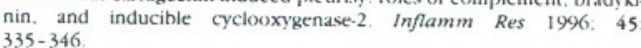

Received 10 September 2001

Accepted 16 October 2001 

in rats: effect on leukocyte endothelial interaction and on leukocyte recruitment. Inflammation Research, 53:442-542, 2004.

\title{
Original Research Papers
}

\section{Chronic blockade of nitric oxide biosynthesis in rats: effect on leukocyte endothelial interaction and on leukocyte recruitment}

\author{
S. H. P. Farsky ${ }^{1}$, P. Borelli ${ }^{1}$, R. A. Fock ${ }^{1}$, S. Z. Proto ${ }^{2}$, J. M. C. Ferreira Jr ${ }^{3}$ and S. B. V. Mello ${ }^{2}$ \\ ' Department of Clinical and Toxicological Analyses, School of Pharmaceutical Sciences, Av. Prof. Lineu Prestes 580, bl. 13B, São Paulo, SP, CEP \\ 05508-900, Brazil \\ 2 Rheumatology Division, Department of Internal Medicine, School of Medicine, University of São Paulo, Av. Dr. Arnaldo, 455, São Paulo, SP, CEP \\ 01246-903, Brazil, Fax: ++551130667490, e-mail: svmello@usp.br \\ ${ }^{3}$ Immunochemistry Laboratory, Butantan Institute, Av. Vital Brazil, 1500, São Paulo, SP, CEP: 05503-900, Brazil
}

Received 14 May 2003; returned for revision 20 June 2003; accepted by N. Boughton-Smith 4 February 2004

\begin{abstract}
Introduction: Previous studies showed that animals chronically treated with NG-nitro-L-arginine methyl ester (L-NAME) have a reduced inflammatory reaction. Now the role of L-NAME treatment $(20 \mathrm{mg} / \mathrm{Kg} /$ day $/ 14$ days $)$ on leukocyte mobilisation was assessed in rats.

Methods: In vivo leukocyte recruitment evoked by Bothrops jararaca venom $(\mathrm{BjV})$ and nitrite/nitrate $\left(\mathrm{NO}_{2}-\mathrm{NO}_{3}^{-}\right.$; Griess reaction) were evaluated in the air pouch cavity. Haematological parameters were evaluated in the bone marrow and in the peripheral compartment. Microcirculatory blood flow, number of rolling and adhered leukocytes, vascular reactivity and mast cell activity were studied by intravital microscopy. Blood pressure was measured by the tail-cuff method. $\mathrm{L}$-selectin and $\beta_{2}$ integrin expressions on peripheral and bone marrow leukocytes were quantified by flow cytometry.

Results: When compared with control rats (D-NAME) L-NAME treated rats had reduced PMN cell infiltrate (50\%) and $\mathrm{NO}_{2}-\mathrm{NO}_{3}{ }^{-}(27 \%)$ in the air pouch cavity. Rolling leukocytes were decreased $(70 \%)$ in L-NAME-treated animals, which was reversed by topical application of NO donor (SIN1). BjV stimulation increased the number of rolling and adhered leukocytes only in control rats. Systemic blood pressure, microcirculatory blood flow and microvascular reactivity was not altered by the treatment. Only the vessel response to acetylcholine was delayed in treated rats. Peripheral PMN cells were increased by L-NAME treatment $(100 \%)$, but the number of bone marrow cells was not altered. The treatment reduced L-selectin expression on circulating leukocytes, by either with $(16 \%)$ or without $(26 \%)$ stimulation with $\mathrm{BjV}$; PMN cells were more affected (32-37\%). Impairment of L-selectin expression was also verified in bone marrow cells under stimulation with $\mathrm{BjV}$.
\end{abstract}

Correspondence to: S. B. V. Mello
Conclusions: Results show that this schedule of L-NAME treatment promotes a decrease on L-selectin expression. This effect may promote the standstill of leukocytes in the blood compartment and may be responsible, at least in part, for the observed deficient leukocyte-endothelium interactions with subsequent impairment of leukocyte migration to the inflammatory site.

Key words: Nitric oxide - Leukocyte-endothelial interactions - Microcirculation - Inflammation - Haematological parameters

\section{Introduction}

The effect of nitric oxide (NO) in the inflammatory reaction is complex since an effective role has been established on the production and mobilisation of leukocytes and on vascular reactivity. Different experimental conditions, doses and administration routes, as well as the tissue employed have determined opposite effects. Thus, NO has been suggested to act either as a pro or anti-inflammatory mediator.

Enhanced production of NO by the inducible form of nitric oxide synthase (iNOS) is associated with the development of inflammatory diseases. It has been demonstrated that in vivo non-specific pharmacological inhibition of nitric oxide synthases (NOS) reduces leukocyte migration to inflammatory sites promoting amelioration of pathological conditions [ $1-8]$. The reduction is not likely to depend on the hypertensive effect evoked by these inhibitors, because pharmacological normalisation of blood pressure does not prevent the decrease in the number of leukocytes migrating to the inflamed area [9]. 
In apparent conflict with these studies, it has been fully demonstrated that both constitutive and inducible generation of NO by competent cells modulates leukocyte-endothelium interaction within the microcirculatory network. Superfusion or bolus injection of non-specific NOS inhibitors, as NGmonomethyl-L-arginine (L-NMMA) or NG-nitro-L-arginine methyl ester (L-NAME), evokes marked increases in the attachment of leukocytes to postcapillary venules and their emigration into the extravascular tissue [10-12]. In addition, treatment with aminoguanidine, a specific iNOS inhibitor, promoted an increase in the number of rolling leukocytes in cat mesentery superfused with TNF- $\alpha$ [13]. A plausible explanation for the effect was interference with superoxide production and mast cell degranulation [14-16]. However, the NO effect on mast cell degranulation is also controversial [17-20].

It is well known that leukocyte-endothelial interaction is dependent on the expression of adhesion molecules. The role of $\mathrm{NO}$ on expression and/or activity of these receptors has not been fully elucidated. In this context, in vivo studies have suggested a correlation between inhibition of $\mathrm{NO}$ production and increment of endothelial adhesion molecules expression $[12,21]$. Additionally, the effect of L-NMMA or L-NAME superfusion in cat or rat microcirculatory vessels is mediated by CD11/CD18 complex expression [22]. The effect of NOS inhibitors directly on blood flow may contribute to the CD18 expression [22]. In vitro studies corroborate the inhibitory effect on vascular adhesion molecules [10,23-26], but do not confirm the participation of CD18 complex detected in vivo through L-NAME superfusion [10].

A role for NO modulating haematopoiesis has been proposed since several studies have demonstrated its interference on progenitor cells, on maturation steps, apoptosis, and bone marrow blood flow [27]. L-NAME treated mice presented lymphopenia and neutrophilia, which were partially reversed by L-Arg administration [28]. These effects may interfere with leukocyte/endothelial interactions, since up and down modulation of adhesion molecules are observed during the intermediate stages of leukocyte maturation [29].

We have previously shown that chronicle L-NAME treatment ( 14 days, $20 \mathrm{mg} / \mathrm{kg}$, oral route) reduces albumin leakage and leukocyte migration to the articular cavity of rabbits in which an arthritic lesion was induced, either immunologically or by the injection of Bothrops jararaca venom (BjV) $[9,30,31]$. The efficacy of NO synthesis blockade was confirmed by a significant reduction in levels of NO metabolites (nitrate/nitrite) in the synovial fluid $[9,30-32]$

The results presented herein show that oral L-NAME chronicle treatment employed in our laboratory promotes impairment in L-selectin expression firstly in PMN. This effect may be responsible, at least in part, for the in vivo deficient leukocyte/endothelium interaction, which may determine a reduced recruitment to the inflamed area and their standstill in the peripheral compartment.

\section{Materials and methods}

Animals

Male Wistar rats, weighing 200-250 g at the beginning of the pharmacological treatment were employed. The animals were allowed a stan- dard pellet diet and water ad libitum. During experimental procedures the animals were anaesthetised to avoid any stress condition. The local Committee for Ethical Surveillance in Animal Experimentation (COBEA) approved the experimental protocol.

\section{L-NAME and D-NAME treatments}

A group of animals were randomly treated with L-NAME or its inactive enantiomer D-NAME (Sigma, St Louis, MO, USA; $20 \mathrm{mg} / \mathrm{Kg} /$ day) mixed in the drinking water. The drugs were administered during two weeks and the experiments, in vivo, in vitro or in situ were then performed.

\section{Bothrops jararaca Venom (BjV)}

Lyophilised crude BjV was a venom pool obtained from several specimens of Bothrops jararaca snakes and was supplied by the Laboratory of Herpetology, Institute Butantan, Brazil. The venom was maintained at $-20^{\circ} \mathrm{C}$, dissolved in sterile saline solution at the moment of the use, the solutions were filtered through a cellulose ester membrane of $0.22 \mu \mathrm{m}$ average pore size

\section{In vivo leukocyte migration: Air Pouch model}

Animals were anaesthetised with pentobarbital sodium (Cristália Brazil; $65 \mathrm{mg} / \mathrm{Kg}$; intraperitoneally) and $10 \mathrm{~mL}$ of sterile air was injected subcutaneously in the dorsal region. Seven days thereafter the pouch was reinstalled with approximately $5 \mathrm{~mL}$ of air. At the 14th day following the first air injection, $\mathrm{BjV}(10 \mu \mathrm{g}$ or $25 \mu \mathrm{g}$ dissolved in $1.0 \mathrm{~mL}$ of sterile saline, $n=6$ for each dose of $\mathrm{BjV}$ ) was injected into the pouch. Control animals received the same volume of sterile saline. Six h later the animals were anaesthetised and sacrificed. The pouches were washed with $3 \mathrm{~mL}$ of Hank's balanced salt solution and the total leukocyte number in the harvested material was determined in Neubaue chambers. Differential cell counts were performed in smears stained with Giemsa dye

Total $\mathrm{NO}_{2} / \mathrm{NO}_{3}^{-}$determination

The concentration of the total amount nitrite/nitrate anions presented in the pouch wash samples collected $6 \mathrm{~h}$ after $\mathrm{BjV}$ injection was determined by Griess reaction. The absorbance was monitored at $646 \mathrm{~nm}$.

\section{Intravital microscopy studies}

Animals were anaesthetised with pentobarbital sodium $(65 \mathrm{mg} / \mathrm{Kg}$; intraperitoneally) and the internal spermatic fascia or cremaster muscle of the wall of the scrotal chamber were exteriorised for microscopic examination in situ $[33,34]$. After surgery, the animals were maintained on a special board thermostatically controlled at $37^{\circ} \mathrm{C}$, which included a transparent platform on which the tissue to be transilluminated was placed. The preparation was kept moist and warmed by irrigating the tissue with warmed Ringer-Locke solution ( $\mathrm{pH} 7.2-7.4 \times \mathrm{NaCl} 154 \mathrm{mM}$; $\mathrm{KCl} 5.6 \mathrm{mM} ; \mathrm{CaCl}_{2} .2 \mathrm{H}_{2} \mathrm{O} 2 \mathrm{mM} ; \mathrm{NaHCO}_{3} 6 \mathrm{mM}$ and glucose $5 \mathrm{mM}$ ) containing $1 \%$ gelatine. The rate of outflow of the solution onto the exposed tissue was controlled to maintain the preparation in continuous contact with a film of the liquid. Transilluminated images were obtained by optical microscopy (Axioplan II, Carl-Zeiss equipped with $\times 5.0 / 0.30$ plan-neofluar or $\times 10.0 / 0.25$ Achroplan longitudinal distance objectives/numeric aperture and $\times 1.0,1.25$ or 1.60 optovar). The images were captured by a video camera (ZVS, 3C75DE, Carl-Zeiss) and were transmitted simultaneously to a TV monitor and to a computer. Images obtained on the TV monitor were recorded on a video, and digitised in the computer and analysed through an image analyser soft- 
ware (KS 300, Kontron). An optical doppler velocimeter was incorporated to the microscope to assess erythrocyte velocity $[35,36]$.

Chronicle administration of L-NAME or D-NAME on leukocyteendothelial interactions, microvascular reactivity, blood flow and mast cell number and degranulation ability were evaluated at 14 th day of the beginning of treatments.

\section{Leukocyte-endothelial interaction}

The number of rolling and adhered leukocytes in postcapillary venules (20-30 $\mu \mathrm{m}$ diameter; $200 \mu \mathrm{m}$ length) of internal spermatic fascia was determined at intervals of $10 \mathrm{~min}$ before and after the topical application of $\mathrm{BjV}(0.25 \mu \mathrm{g} / 10 \mu \mathrm{L}, \mathrm{n}=6$ for L-NAME and control groups). In another group $(n=4)$ of L-NAME and D-NAME treated animals the effect of topical application of a nitric oxide donor, 3-morpholinosydnonimine (SIN-1, $10 \mathrm{mM}$ ) on leukocyte-endothelial interactions was observed.

\section{Microvascular reactivity}

The constrictor response to noradrenaline (NA, 1, 2.5, $5 \mu \mathrm{g} / \mathrm{mL}$, Sigma, St Louis, MO, USA) and vasodilatation to acetylcholine (Ach, $300 \mu \mathrm{g} / \mathrm{mL}$, Sigma, St Louis, MO, USA) and histamine $(50 \mu \mathrm{g} / \mathrm{mL}$, Sigma, St Louis, MO, USA) were tested. Drugs dissolved in Ringer-Locke's solution were topically applied to vessels $(20-30 \mu \mathrm{m})$ of the internal spermatic fascia or cremaster muscle in a standard volume of $10 \mu \mathrm{L}$ and removed by washing with Ringer-Locke's solution. Animals of each group ( $n=4-6$ ) were tested for the different stimulus. The latency time required to the arteriole stasis in response to each dose of NA and the subsequent re-flow in response to Ach were recorded. Changes in venule diameter, expressed as percentage of increasing of the initial diameter in response to histamine was addressed. Results are expressed as mean \pm S.E.M of 4-6 rats for each group, in which were evaluated 5 fields.

\section{Mast cell: number and activity}

Other set of experiments was designed to assess the interference of L-NAME treatment on mast cell. The degranulation of mast cells under topical application of $10 \mu \mathrm{g}$ of $48 / 80$ compound (Sigma, St Louis, MO, USA) was determined in the adjacent tissue to postcapillary venules of internal spermatic fascia. The number of mast cell degranulated in an area of $7,200 \mu \mathrm{m}^{2}$ and the time of latency required to begin the process was recorded in 10 vessels of each animal. The number of constitutive mast cells was evaluated after 5 min of topical application of blue toluidin dye (Sigma, St. Louis, MO, USA) and 10 areas were evaluated. It was employed 4-6 animals for each group, in each assay.

\section{Blood pressure measurement}

Arterial blood pressure was measured in $6 \mu \mathrm{m}$ anaesthetised animals of each group by tail plethysmography using a programmed E\&M Instrument Co electrosphygmomanometer (Narco Bio System, Texas, USA). The rats were placed in a warming chamber maintained at $37^{\circ} \mathrm{C}$ for $10 \mathrm{~min}$ to allow pulses to be recorded. The cuff pressure was controlled automatically and the systolic pulses detected by the pulse transducer were monitored with the audio signal. The average of five successive measurements was taken as the mean systolic pressure value.

\section{Haematological parameters}

Blood

Animals (6-8 for each group) were anaesthetised with pentobarbital sodium $(65 \mathrm{mg} / \mathrm{Kg}$, intraperitoneally) and whole blood samples with
EDTA ( $1 \mathrm{mg} / \mathrm{mL}$, Sigma, St. Louis, MO, USA) were obtained via abdominal aorta punctures and collected concomitantly with bone marrow cells The haemoglobin concentration [37] and hematocrit were [38] determined by standard methods. Total cells were quantified using a Neubauer chamber. Differential leukocytes counts were performed on blood smears stained May Grumwald- Giemsa solution (Sigma, St. Louis, MO, USA)

Bone marrow and splenic cells

Bone marrow cells were obtained by flushing the femoral cavity with the McCoy's 5A medium (Sigma, St. Louis, MO, USA) with EDTA $(1 \mathrm{mg} / \mathrm{mL})$. Spleens were removed, placed in Petri dishes containing McCoy's 5A medium (Sigma Chemical Co., St. Louis, MO) with EDTA $(1 \mathrm{mg} / \mathrm{mL})$ and gently dissociated. The number of total cells was quantified in Neubauer chamber. Differential counts were performed on the basis of 500 cells per slide in cytocentrifuge smears stained by MayGrumwald and Giemsa dye.

\section{Flow cytometry}

Leukocytes were isolated from blood collected from the orbital plexus using EDTA or from bone marrow (4 L-NAME and 4 control animals) to quantify L-selectin or $\beta_{2}$ integrin expression. Briefly, erythrocyte lysis was performed using ammonium chloride solution $(0.13 \mathrm{M})$ and leukocytes were recovered after washing with Hank's balanced solution (HBSS). Cells $\left(1 \times 10^{6}\right)$ were incubated with or without BjV $(1-5 \mu \mathrm{g} /$ 10 or $30 \mathrm{~min}$ ). After washing, leukocytes were further incubated for $30 \mathrm{~min}$ at $4^{\circ} \mathrm{C}$ in the dark with $10 \mu \mathrm{L}$ of IgG 1 -FITC and $10 \mu \mathrm{l}$ of primary monoclonal antibody against L-selectin (FITC conjugated, hamster anti-rat L-selectin, Seikagaku corporation, Tokyo, $50 \mu \mathrm{g} / \mathrm{mL}$ ) or $\beta_{2}$ integrin (FITC conjugated, mouse anti-rat CD 18, BD PharMingen Technical, CA, USA, $50 \mu \mathrm{g} / \mathrm{mL}$ ). Immediately after incubation, cells were analysed on a FACScalibur flow cytometer (Becton \& Dickinson - San Jose, CA, USA). Data from 10,000 cells were obtained and only the morphologically viable leukocytes were considered for analysis.

\section{Statistical analysis}

Means and standard error of means (SEM) of all data are presented and were compared by student's $t$-test or Mann \& Whitney test with significant probability levels of less than 0.05 .

\section{Results}

In vivo leukocyte migration

To investigate the effect of L-NAME treatment on in vivo leukocyte recruitment, groups of L-NAME or D-NAME treated animals were injected with increasing doses of BjV. Results presented in figure 1 show that oral L-NAME administration impaired the leukocyte migration $6 \mathrm{~h}$ after $\mathrm{BjV}$ injection. The number of polymorphonuclear cells (PMN) in the inflammatory reaction induced by $\mathrm{BjV}$ was reduced in L-NAME treated rats when compared with control animals (D-NAME). Total amount of nitrite/nitrate anions presented in the control pouch wash samples was $26 \pm 0.68 \mu \mathrm{M}$ and $19.53 \pm 0.85 \mu \mathrm{M}$ in LNAME treated animals $(n=5 ; p<0.001)$.

\section{Leukocyte-endothelial interactions}

The contribution of NO to leukocyte-endothelial interactions was examined by determining the number of rolling and 


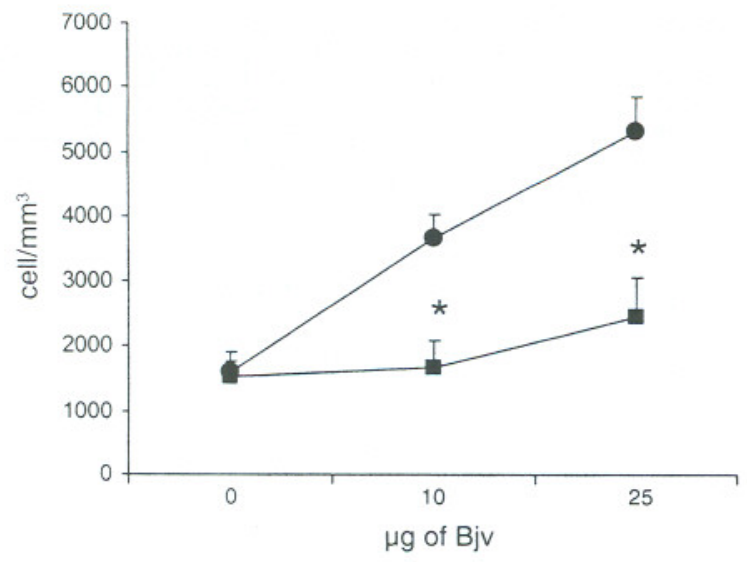

Fig. 1. Leukocyte influx into rat air pouch cavity, $6 \mathrm{~h}$ after 10 or $25 \mu \mathrm{g}$ of BjV injection = L-NAME $(20 \mathrm{mg} / \mathrm{Kg}$ /day for 14 days $)$ : $=\mathrm{D}$ NAME treated rats $(20 \mathrm{mg} / \mathrm{Kg} /$ day for 14 days $)$. Results are expressed as mean \pm S.E.M. of six rats in each group. ${ }^{*} \mathrm{p}<0.05 \mathrm{vs}$. control.
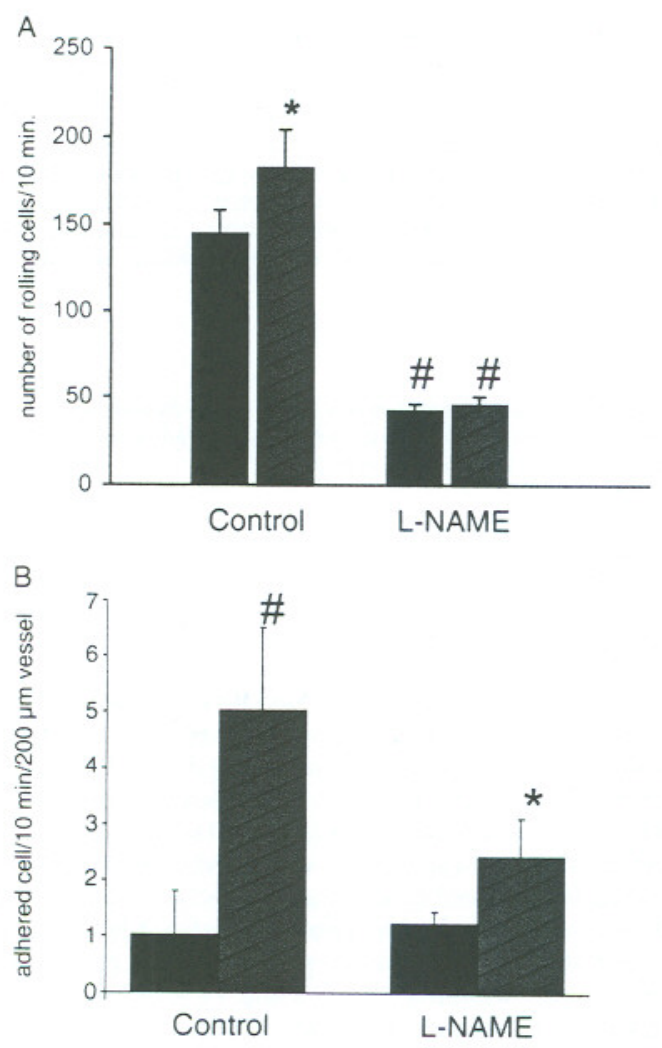

Fig. 2. Number of rolling (Panel A) and adhered leukocytes (Panel B) in postcapillary venules of the internal spermatic fascia of L-NAME (20 $\mathrm{mg} / \mathrm{Kg} / 14$ days; $\mathrm{n}=6)$ and D-NAME $(20 \mathrm{mg} / \mathrm{Kg} / 14$ days; $\mathrm{n}=6)$ treated rats. Black columns represent the number of rollers before $\mathrm{BjV}$ and striped columns represent values obtained after the topical administration of $0.25 \mu \mathrm{g}$ of $\mathrm{BjV} .{ }^{*} \mathrm{P}<0.05 \mathrm{vs}$ initial values $\# \mathrm{P}<0.001$ vs. control. adhered cells in postcapillary venules of the internal spermatic fascia of L-NAME treated rats. As shown in figure $2 \mathrm{~A}$, L-NAME reduced the number of rolling leukocytes, either before or after BjV topical application. Adhered cells, in basal conditions, were quantitatively equivalent in both groups of animals (Figure 2B). However, the increment in the number of adhered cells induced by $\mathrm{BjV}$ was much lesser in L-NAME treated rats than in controls.

To assess the contribution of NO in L-NAME treated rats, a set of L-NAME- or D-NAME-treated animals received a topical application of the NO donor SIN-1 (10 mM). Data obtained demonstrated that SIN-1 reversed the decrease in the number of rolling leukocytes previously observed in L-NAME-treated animals. Twenty min after SIN-1 addition, the number of rolling leukocytes was similar to that observed in control animals (Figure 3). In both group of animals was detected decreasing in blood flow, however the reduction was more intense in L-NAME treated rats (control: 10\%; L-NAME treated: $23 \% ; n=4$ ).

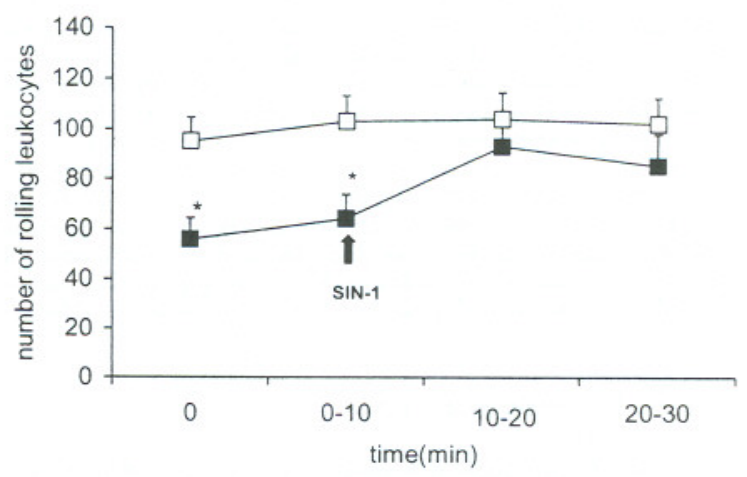

Fig. 3. Number of rolling leukocytes in postcapillary venules of the internal spermatic fascia of rats treated with L-NAME $(\mathbb{\square} 20 \mathrm{mg} / \mathrm{Kg} / 14$ days; $\mathrm{n}=4)$ and D-NAME $(20 \mathrm{mg} / \mathrm{Kg} / 14$ days; $\mathrm{n}=4)$ before and after the topical application of nitric oxide donor (SIN-1, $10 \mathrm{mM}) .{ }^{*} \mathrm{p}<0.05$ vs. control.

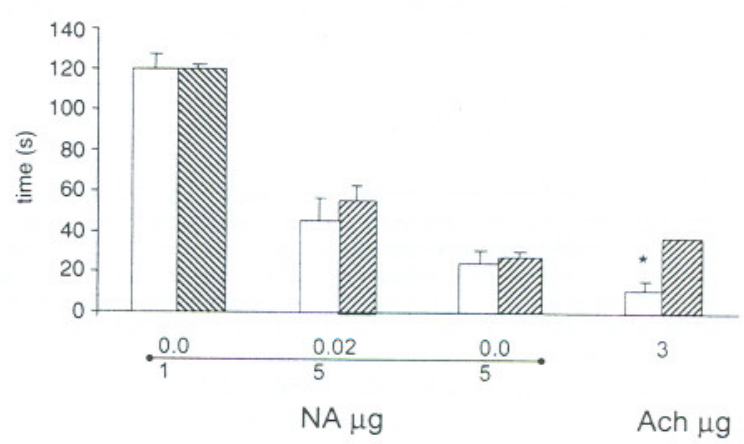

Fig. 4. Effect of L-NAME treatment $(20 \mathrm{mg} / \mathrm{Kg} / 14$ days) on in vivo arteriolar response to noradrenaline and acetylcholine. Data represent the time required to cessation of blood flow. White columns show mean \pm S.E.M. of values obtained in 4-6 control animals (D-NAME $20 \mathrm{mg} / \mathrm{Kg} / 14$ days) and the striped column values obtained in $4-6 \mathrm{~L}$ NAME treated rats. ${ }^{*} p<0.05$ vs. control values. 
Anexo 5. Trabalho apresentado: FARSKY, S.H.P.; BORELLI, P.; FOCK, R.A.; PROTO, S.Z.; FERREIRA, J.M.C.; MELLO, S.B.V. Chronic blockage of nitric oxide biosynthesis in rats: effect on leukocyte endothelial interaction and on leukocyte recruitment. Inflammation Research, 53:442-542, 2004.

Table 1. Haemodynamic parameters (erythrocyte velocity in postcapillary venules and systemic blood pressure) in L-NAME ( $20 \mathrm{mg} / \mathrm{Kg} /$ day for 14 days $)$ and D-NAME treated animals $(20 \mathrm{mg} / \mathrm{Kg} /$ day for 14 days $) . \mathrm{n}=$ number of animals in each group. Results are expressed as mean \pm S.E.M.

\begin{tabular}{llll}
\hline Treatment & Erythrocyte velocity $(\mathrm{mm} / \mathrm{seg})$ & Mean blood Pressure (mmHg) \\
\cline { 2 - 4 } & Before BjV & After BjV & \\
\hline Control $(\mathrm{n}=6)$ & $2.9 \pm 0.15$ & $2.8 \pm 0.30$ & $118 \pm 13.4$ \\
L-NAME $(\mathrm{n}=6)$ & $3.2 \pm 0.37$ & $2.6 \pm 0.05$ & $125 \pm 9.7$ \\
\hline
\end{tabular}
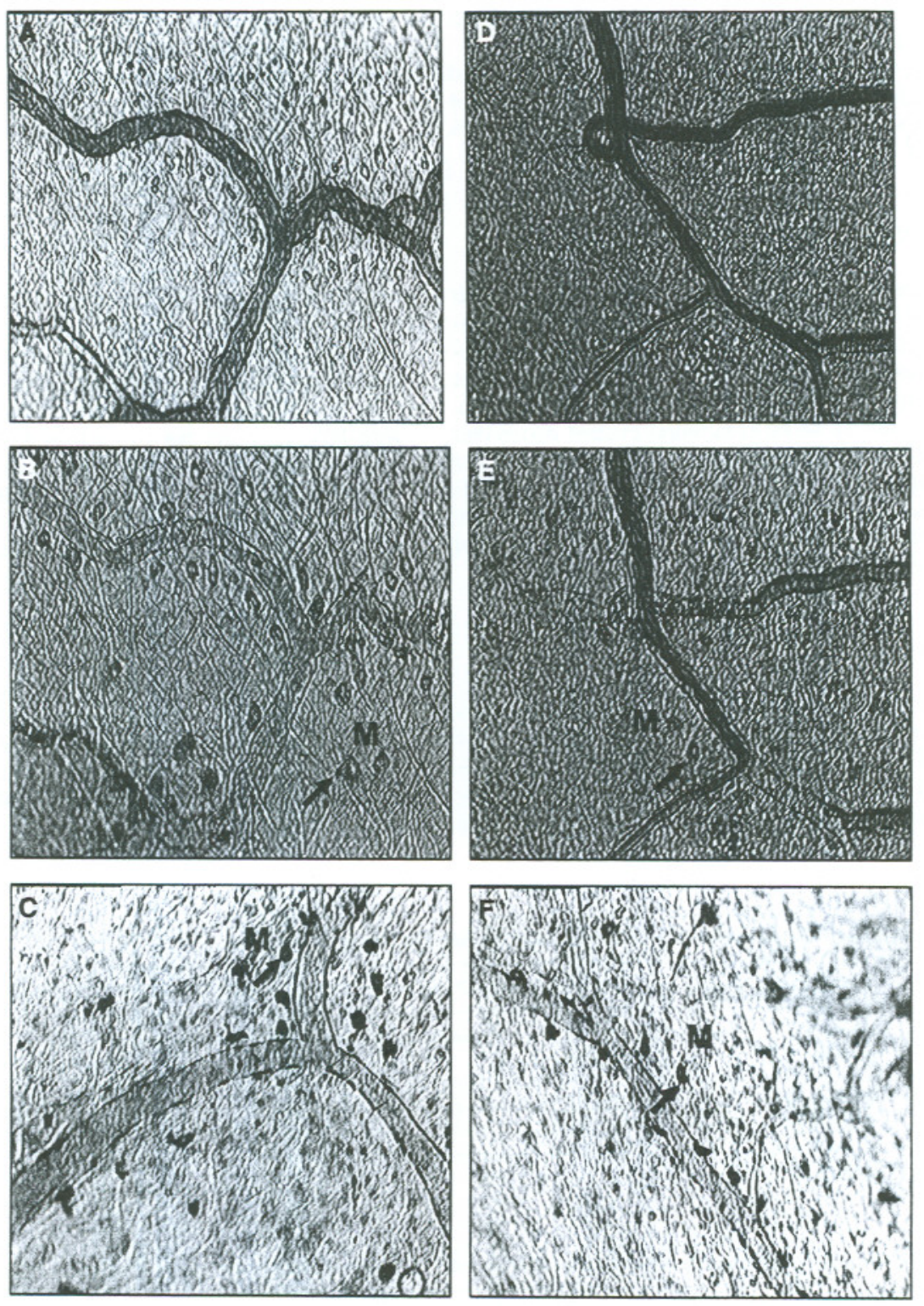

Fig. 5. Mast cells activity and number. Panel A and D show normal venules $(20 \mu \mathrm{m})$ in the spermatic fascia of control and L-NAME treated animals (20 $\mathrm{mg} / \mathrm{Kg} / 14$ days) respectively. Panels $\mathrm{B}$ and $\mathrm{E}$ exhibit the degranulation of perivascular mast cells under topical application of $10 \mu \mathrm{g}$ of $48 / 80$ compound in control and L-NAME treated animals, respectively. Panels $\mathrm{C}$ and $\mathrm{F}$ show the number of perivascular mast cells 5 min after topical application of blue toluidin dye in control (D-NAME $20 \mathrm{mg} / \mathrm{Kg} / 14$ days) and L-NAME treated animals, respectively. Bar $=40 \mu \mathrm{m}$. 
Microvascular response to Noradrenaline. Acetylcholine and Histamine

At resting conditions, diameters of arterioles and venules of L-NAME and D-NAME treated rats were not different (data not shown). Results presented in figure 4 shows that L-NAME treatment did not interfere with arteriolar reactivity in response to NA. Similar dose-response was observed in both groups of animals studied. On the other hand, the subsequent re-flow induced by Ach was significantly de-layed in L-NAME treated animals in comparison to controls (Figure 4).

In addition, vessel response to histamine was not altered by L-NAME treatment. Equivalent dilation was recorded in both groups of animals, $20 \%$ for venules and about $10-15 \%$ for arterioles ( $n=4-6$ for each group of animals).

\section{Mast cell: number and activity}

Results depicted in figure 5 show that chronicle L-NAME treatment, here employed, does not interfere with the number or degranulation ability of mast cells adjacent to venules. The average of mast cell number was similar in L-NAME (16.26 \pm 2.11$)$ and control animals (12.38 \pm 0.45$)$. Topical application of $48 / 80$ compound evoked equivalent mast cell degranulation in both groups. The time required to degranulate was about $30 \mathrm{~s}$, and the numbers of degranulated cells in adjacent area of postcapillary venules were 13.26 \pm 0.57 for L-NAME treated rats and $15.25 \pm 1.1$ for control animals (4-6 animals in each group).

\section{Haemodynamic parameters}

Results presented in table 1 indicate that L-NAME administration, as currently employed, did not significantly affect systemic blood pressure or erythrocyte velocity in postcapillary venules. Therefore the impairment in leukocyte-endothelial interactions could not be ascribed to haemodynamic factors.

\section{Haematological parameters}

L-NAME administration did not modify the total cellularity of the bone marrow and spleen or the distribution of the different cellular populations (Table 2). Shunting line to the left in the granulocyte sector was not observed. However L-NAME treatment promoted a markedly increase $(111 \%)$ in the absolute number of circulating neutrophils (Table 3), being that this rise did not reflect the appearance of band cells. Others blood parameters such as erythrocyte, reticulocyte and platelet numbers, haemoglobin concentration and hematocrit were not modified by L-NAME treatment (data not shown).

\section{L-selectin and CDI8 expression}

Surface expressions of L-selectin and CD 18 were investigated in circulating and bone marrow leukocytes using immunofluorescence flow cytometry. Images presented in figure $6 \mathrm{~B}$ and $6 \mathrm{C}$ demonstrate that L-NAME, but not D-NAME, reduced Lselectin expression, particularly noticeable in PMN cells. The reduction was detected in cells even stimulated or not with $\mathrm{BjV}$ (Fig. 6A). Pre incubation of cells, collected from control rats, with $\mathrm{BjV}$ increases the expression of both adhesion moleculesby about $30 \%$ (not shown). On the other hand, $\beta_{2}$ integrin expression was not altered by L-NAME treatment even with or without stimulation (data not shown).

Additionally, impairment on L-selectin expression may be present in bone marrow cells. The treatment did not alter the basal expression of L-selectin on membrane of early, mature PMN cells or lymphocyte and blastocytes (figure 7, panels $\mathrm{A}$ and $\mathrm{C}$ ). On the other hands, under stimulation with $\mathrm{BjV}$ the expression was highly increased in cells obtained from control animals (early $\mathrm{PMN}=40 \%$; mature $\mathrm{PMN}=$ $100 \%$ and lymphocyte and blastocytes $=100 \%$, figure 7 , panels A and B), but cells collected from bone marrow of L-NAME treated animals were not able to respond to the stimulus (figure 7, panels $\mathrm{C}$ and $\mathrm{D}$ ).

Table 2. Cell counts in bone marrow and spleen of control and L-NAME treated rats.

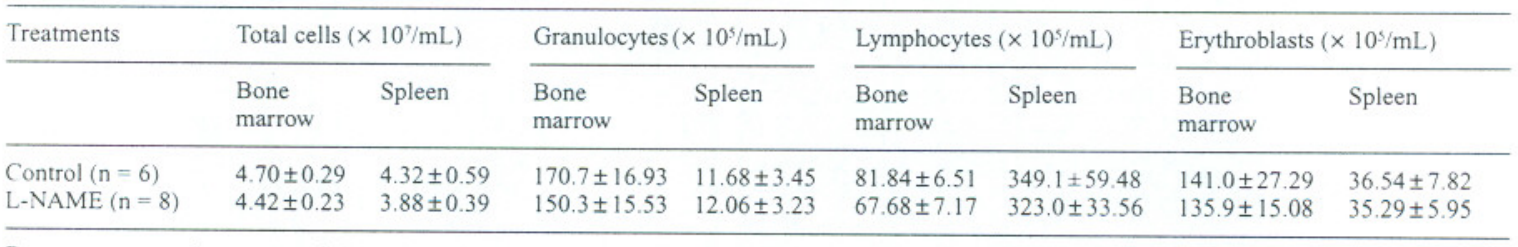

Data are expressed as mean \pm S.E.M.

Table 3. Total and differential leukocytes counts in blood of control and L-NAME treated rats. Results are presented as mean \pm S.E.M.

\begin{tabular}{lllll}
\hline Treatments & Leucocytes $\left(\mathrm{mm}^{3}\right)$ & Neutrophils $\left(\mathrm{mm}^{3}\right)$ & Lymphocytes $\left(\mathrm{mm}^{3}\right)$ & Monocytes $\left(\mathrm{mm}^{3}\right)$ \\
\hline Control $(\mathrm{n}=6)$ & $4,819 \pm 516$ & $471 \pm 77$ & $3,763 \pm 495$ & $139 \pm 42.5$ \\
L-NAME $(\mathrm{n}=7)$ & $5,714 \pm 469$ & $993 \pm 136^{*}$ & $4,031 \pm 548$ & $185 \pm 31.9$ \\
\hline$*$ P $<0.05$ v. respective & & & \\
\hline
\end{tabular}


Anexo 5. Trabalho apresentado: FARSKY, S.H.P.; BORELLI, P.; FOCK, R.A.; PROTO, S.Z.; FERREIRA, J.M.C.; MELLO, S.B.V. Chronic blockage of nitric oxide biosynthesis in rats: effect on leukocyte endothelial interaction and on leukocyte recruitment. Inflammation Research, 53:442-542, 2004.

\begin{tabular}{|lcc|}
\hline \multirow{3}{*}{ A \% reduction of selectin expression vs control } \\
\cline { 2 - 3 } & $\begin{array}{c}\text { Basal } \\
\text { expression }\end{array}$ & $\begin{array}{c}\text { Stimulated with } \\
\text { Bjv }\end{array}$ \\
\hline Total leukocyte & $26.15^{*}$ & $16.39^{*}$ \\
lymphocyte & $19.25^{*}$ & 5.17 \\
Polymorphonuclear & $37.29^{*}$ & $32.17^{*}$ \\
\hline
\end{tabular}
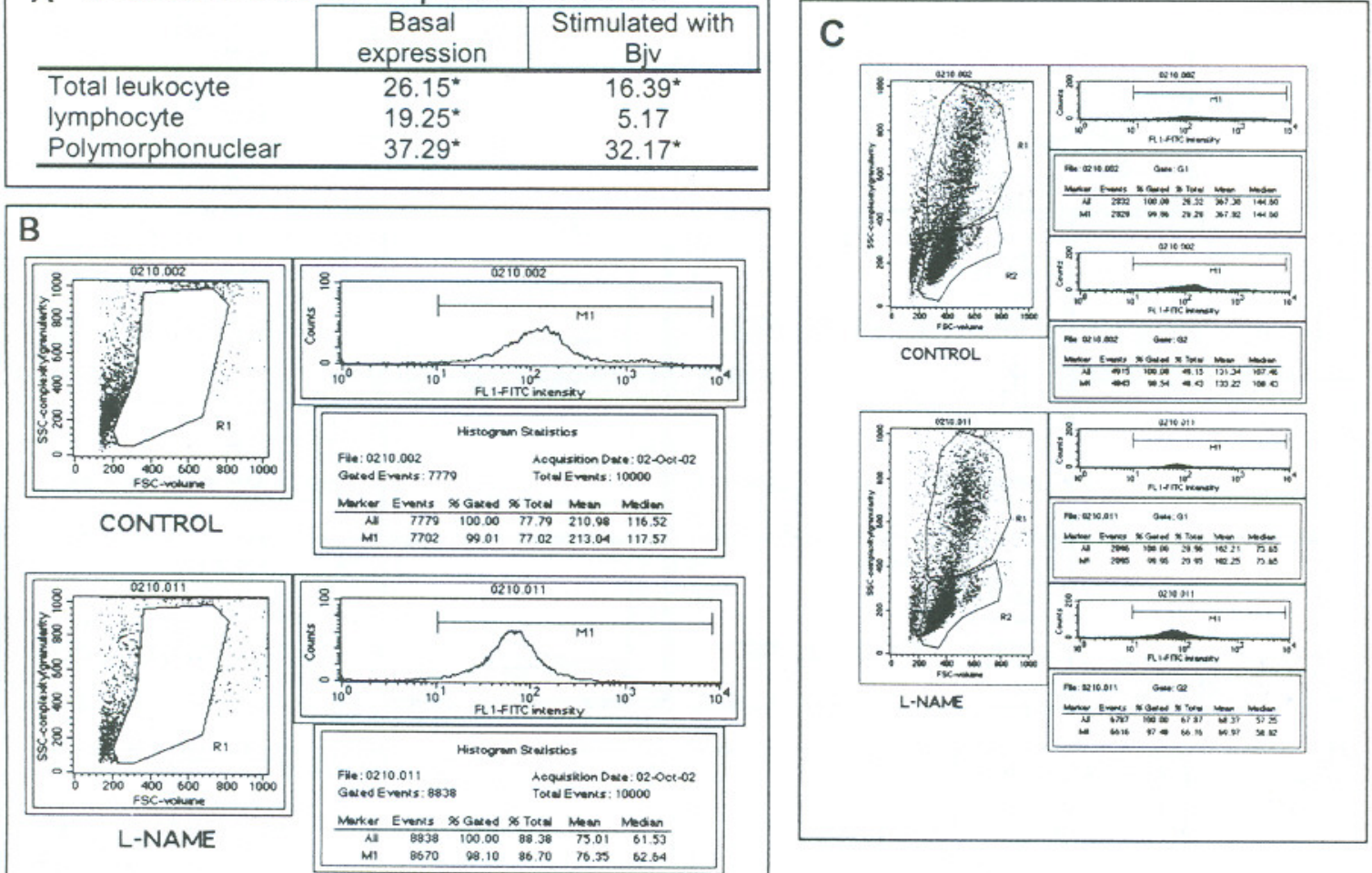

Fig. 6. L-selectin expression on peripheral leukocytes obtained from L-NAME and D-NAME treated rats. Data were obtained in blood flow cytometry. (A) Represents percentage of reduction of L-selectin in L-NAME treated animals $(20 \mathrm{mg} / \mathrm{Kg} / 14$ days; $\mathrm{n}=4)$ in relation to D-NAME (20 mg/ $\mathrm{Kg} / 14$ days; $\mathrm{n}=4)$, in basal and following stimulation by $\mathrm{BjV}(10 \mu \mathrm{g}$ of $\mathrm{BjV})$. Panel B shows images observed in total leukocytes and $\mathrm{C}$ demonstrate images from polymorphonuclear (PMN) and mononuclear (MN) cells. ${ }^{*} \mathrm{p}<0.05 \mathrm{vs}$. control.

\section{Discussion}

In the current study we have clearly show that chronic unspecific NOS inhibition evokes impairment on leukocyte-endothelial interactions, visualised by decreasing on the number of rolling and adhered leukocytes to the postcapillary venule endothelium. The reversal of rolling behaviour following local application of the NO donor SIN-1 indicates that the relative lack of NO in L-NAME treated rats appears to be the major determinant for the effect. These data are surprising since the literature has determined NO as a modulator of leukocyteendothelium interactions. However, these studies were performed using higher doses and acute treatments with NOS inhibitors or NO donors $[10,11,13-16]$. Possibly, differences obtained between studies are attributed to the amount of NO produced as an outcome of pharmacological treatments. This hypothesis is based on observations that $\mathrm{NO}$ is recognised as a protective or injurious agent in physiological and pathological conditions depending on the amount produced, the site of production, and the presence of other reactive species $[25,39,40]$. It is important to emphasise that our treatment does not induce a total blockage in NO synthesis, since nitrite/nitrate levels in air pouch inflammatory exudate was reduced by about $30 \%$.
The alterations on leukocyte behaviour on microvessels, observed in basal conditions, persisted during the development of an inflammatory response evoked by the topical application of $\mathrm{BjV}$. The increase in number of rolling and adhered leukocyte evoked by the venom in control animals was not observed in L-NAME treated rats.

The migration of leukocytes from the vascular system to the injured area is a key event in inflammation. In this context, tethering and rolling of leukocytes on the vessel wall is the initial and fundamental event, following by firmly adherence to the endothelium. These cellular interactions in vivo are influenced by alterations on microcirculatory haemodynamics, leukocytes and platelet aggregation as well as other blood component, and by endogenous mediators liberated by interstitial cells. Our results indicate that inhibition on leukocyte-endothelial interaction by L-NAME treatment does not reflect haemodynamics modification, since erythrocyte velocity on postcapillary venule and arteriolar or venular response to vasoactive substances, such as noradrenaline and histamine are not altered. As expected, a delayed response to acetylcholine was recorded in L-NAME treated rats. Systemic blood pressure is also similar in control and L-NAME treated animals. The observed effect is not surprisingly since 
Anexo 5. Trabalho apresentado: FARSKY, S.H.P.; BORELLI, P.; FOCK, R.A.; PROTO,

S.Z.; FERREIRA, J.M.C.; MELLO, S.B.V. Chronic blockage of nitric oxide biosynthesis in rats: effect on leukocyte endothelial interaction and on leukocyte recruitment. Inflammation Research, 53:442-542, 2004.
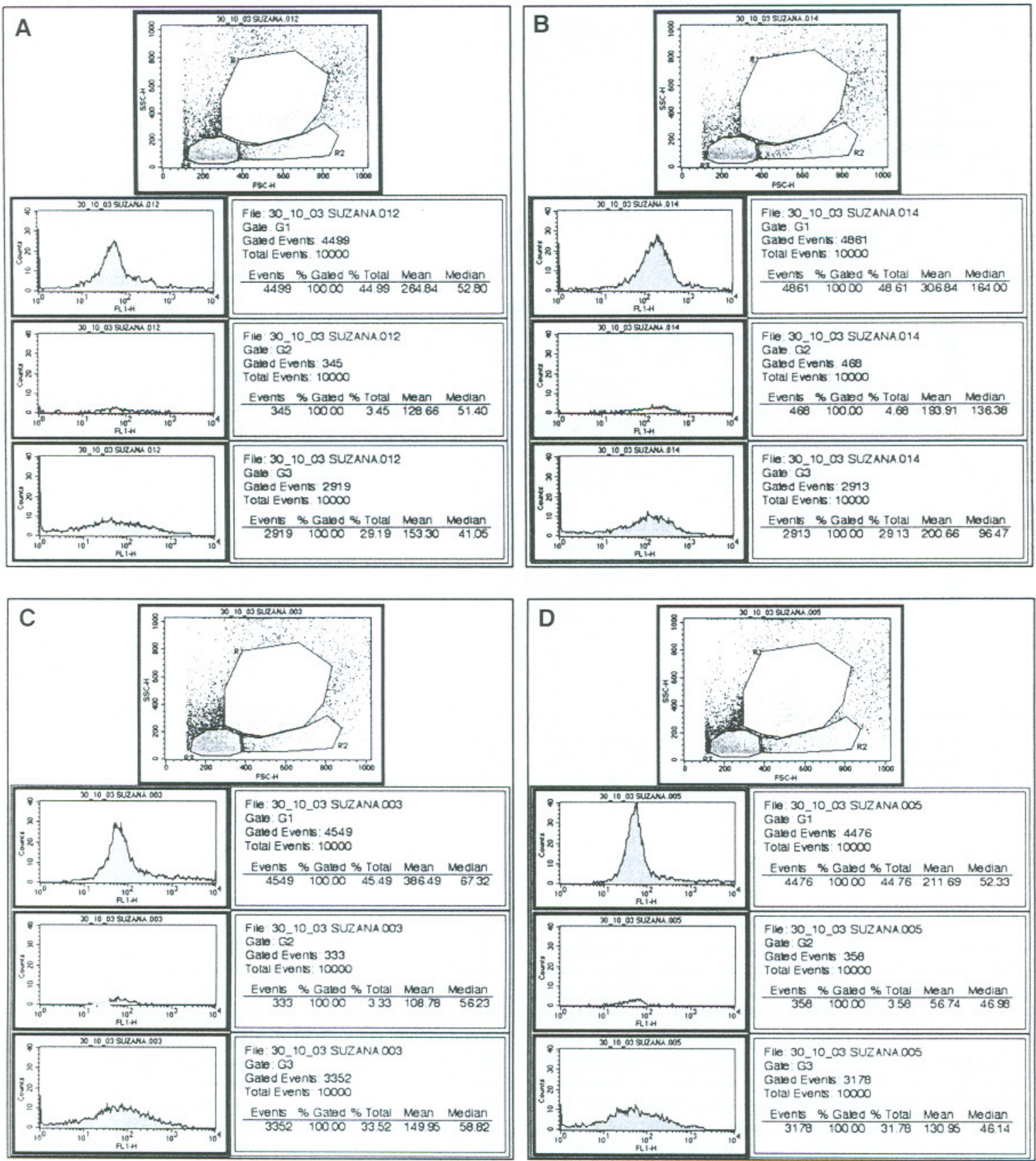

Fig. 7. L-selectin expression on bone marrow leukocytes obtained from L-NAME and D-NAME treated rats. Figures represent L-selectin expression in non-stimulated $(\mathrm{A})$ and stimulated with BjV (B) leukocytes collected from control animals. Panels $\mathrm{C}$ and $\mathrm{D}$ represent equivalent results obtained in cells collected from $\mathrm{L}-\mathrm{NAME}$ treated rats $(20 \mathrm{mg} / \mathrm{Kg} / 14$ days; $n=4) . R 1=$ mature PMN; R2 = early PMN; R3 = lymphocyte and blastocytes 
it has been shown that increment on blood pressure by L-NAME treatment is achieved by higher doses and during a longer time of treatment than here employed [41-44].

Mediators secreted by mast cells, mainly histamine, are clearly associated to induction of rolling behaviour $[45,46]$. It has been suggested that NO plays a role in the in vivo modulation of mast cell degranulation and histamine release [17, $18,20,47]$. The possibility that our treatment could inhibit mast cell activity and consequently impair the leukocyteendothelial interactions was excluded by the observations that the number of mast cells on adjacent tissue to postcapillary venule and their ability of degranulating in response to $48 / 80$ compound was not modified.

The impaired leukocyte-endothelium interaction in L-NAME-treated rats may be responsible, at least in part, by the reduction of leukocyte influx to the air pouch in response to $\mathrm{BjV}$. We had already demonstrated that rabbits submitted to the same pharmacological treatment had reduction in cellular recruitment and vascular permeability on arthritis induced even by $\mathrm{BjV}$ or by serum albumin bovine $[9,30-$ $32]$. Additionally, the reduced inflammatory response observed in L-NAME treated rats is in agreement with other experimental studies which employed different schedules of treatments and stimulus [48-51]. Although we demonstrated that L-NAME treatment promotes leukocyte-endothelial impairment, a direct effect on leukocyte locomotion should not be excluded. Previous studies demonstrated that in vitro incubation with NOS inhibitors attenuates subsequent chemotaxis of polymorphonuclear cells [52-55]. It is important to note that this protocol of treatment also promoted reduction on IL1 and eicosanoids levels on inflammatory exudates, which may contribute to the impairment of the inflammatory reaction $[9,30,32]$.

During the course of an inflammatory reaction, neutrophils first bind loosely to endothelial cells and this is due to the interaction between selectin molecules expressed, such as on endothelium and leukocytes, and their ligands. Neutrophils then roll on the vessel wall in the direction of the blood stream. Subsequent adherence is dependent on leukocyte integrin expression and the intervention of immunoglobulin adhesion molecules on the endothelial cell membrane. Downregulation of endothelial molecules has been observed in cultures of normal cells submitted to the action of exogenous NO donors $[23,24,26,56,57]$. The participation of $\mathrm{NO}$ derived from constitutive NOS and the exclusion of NO derived from iNOS on basal up expression of P-selectin was ascertained with the use of knockout mice [58]. Additionally, In vitro incubation of human neutrophils with L-NAME promoted increment on function of $\beta_{1}$ integrin, but did not modify their expression [59]. The role of $\mathrm{NO}$ on in vivo adhesion molecule expression is now suggested, by the expression of L-selectin on peripheral leukocytes. Nonspecific chronic blockade of NO synthesis promoted a reduction in the expression of this component of the selectin family in circulating PMN, which are the predominant cells in the air pouch infiltrate. Interestingly, the impairment on molecule expression was detected even in basal conditions. On the other hand, the treatment did not affect the expression of $\beta_{2}$ integrin. However, modification on activity of this molecule cannot be excluded, and it will be further investigated.
Different growth factors, cytokines, hormonal action and plasmatic and cellular mediators of the inflammatory response, including NO, influence haematopoiesis [27, $60-62]$. NO is a potent inhibitor of haematopoiesis, but the levels required for the inhibition in vitro may not be physiologically important. Additionally, erythroid and myeloid progenitor cells appear to have differential sensitivity to NO $[63,64]$. Determination of myeloid and erythroid cell numbers at different stages of maturation in the bone marrow demonstrated that haematopoiesis was not altered by LNAME treatment, however the number of circulating neutrophils is markedly increased. The analysis of blood and medullar erythropoiesis in L-NAME treated animals excluded haemoconcentration or haemolytic nature in the effect, which suggesting the standstill of PMN in the peripheral compartment.

It has been fully demonstrated that each stage of cell maturation is associated with the expression of a particular combination of adhesion molecules, which may therefore play general roles in compartmentalisation and development of leukocytes [65-67]. Here we showed that basal expression of L-selectin on early or mature PMN, lymphocyte and blastocytes of bone marrow was not modified by L-NAME treatment. However, under stimulatory condition, all lines of cells obtained from treated rats were completely incapable of increasing L-selectin expression.

Together, these data suggest that treatment with L-NAME here employed promotes impairment of L-selectin expression, even in the medullar compartment. The continued effect on the leukocyte circulating pool may be responsible for the standstill of neutrophils in the peripheral compartment and for the deficient leukocyte/endothelium interaction, which may underlie the reduced recruitment to the inflamed area.

Acknowledgements. The authors thank Dr. João Garcia Leme for his helpful discussion and Maria de Fátima de Almeida. Maria Aurora Gomes da Silva, Carla Cristina Prizon for technical assistance. This work was supported by FAPESP grants \# 02/02659-5.

\section{References}

[1] Ialenti A, Moncada S, Di Rosa M. Modulation of adjuvant arthritis by endogenous nitric oxide. Br J Pharmacol 1993; 110: 701-6.

[2] McCartney-Francis N, Allen JB, Mizel DE, Albina JE, Xie QW, Nathan CF et al. Suppression of arthritis by an inhibitor of nitric oxide synthase. J Exp Med 1993; 178: 749-54.

[3] Stefanovic-Racic M, Meyers K, Meschter C, Coffey JW, Hoffman $\mathrm{RA}$, Evans $\mathrm{CH}$. Comparison of the nitric oxide synthase inhibitors methylarginine and aminoguanidine as prophylactic and therapeutic agents in rat adjuvant arthritis. J Rheumatol 1995; 22: 1922-8.

[4] Medeiros MV, Binhara IM, Moreno JH, Zatz R, De Nucci G, Antunes E. Effect of chronic nitric oxide synthesis inhibition on the inflammatory responses induced by carrageenin in rats. Eur J Pharmacol 1995; 285: 109-14.

[5] Salvemini D, Settle SL, Masferrer JL, Seibert K, Currie MG, Needleman $\mathrm{P}$. Regulation of prostaglandin production by nitric oxide; an in vivo analysis. Br J .Pharmacol 1995; 114: 1171-8.

[6] Salvemini D, Wang ZQ, Wyatt PS, Bourdon DM, Marino MH, Manning PT et al. Nitric oxide: a key mediator in the early and late phase of carrageenan-induced rat paw inflammation. Br J Pharmacol 1996; 118: 829-38.

[7] Salvemini D, Manning PT, Zweifel BS, Seibert K, Connor J, Currie $M G$ et al. Dual inhibition of nitric oxide and prostaglandin pro- 
duction contributes to the antiinflammatory properties of nitric oxide synthase inhibitors. J Clin Invest 1995; 96: 301-8.

[8] Weinberg JB, Granger DL, Pisetsky DS, Seldin MF, Misukonis $\mathrm{MA}$, Mason SN et al. The role of nitric oxide in the pathogenesis of spontaneous murine autoimmune disease: increased nitric oxide production and nitric oxide synthase expression in MRL-lpr/lpr mice, and reduction of spontaneous glomerulonephritis and arthritis by orally administered NG-monomethyl-L-arginine. J Exp Med 1994: 179:651-60

[9] Palácios FA, Novaes GS, Guzzo ML, Laurindo IM, Mello SB. Interrelationship of the kinin system, nitric oxide and eicosanoids in the antigen-induced arthritis in rabbits. Mediators Inflamm $1999 ; 8: 245-51$.

[10] Kubes P, Suzuki M, Granger DN. Nitric oxide: an endogenous modulator of leukocyte adhesion. Proc Natl Acad Sci USA 1991; $88: 4651-5$

[11] Arndt H, Russell JB, Kurose I, Kubes P, Granger DN. Mediators of leukocyte adhesion in rat mesenteric venules elicited by inhibition of nitric-oxide synthesis. Gastroenterology 1993; 105: 675-80.

[12] Davenpeck KL, Gauthier TW, Lefer AM. Inhibition of endothelialderived nitric oxide promotes P-selectin expression and actions in the rat microcirculation. Gastroenterology 1994; 107:1050-8.

[13] Kubes P, Sihota E, Hickey MJ. Endogenous but not exogenous nitric oxide decreases TNF-alpha-induced leukocyte rolling. Am J Physiol 1997: 273: G628-35.

[14] Kubes P, Kanwar S, Niu XF, Gaboury JP. Nitric oxide synthesis inhibition induces leukocyte adhesion via superoxide and mast cells. FASEB J 1993; 7: 1293-9.

[15] Gaboury J, Woodman RC, Granger DN, Reinhardt P, Kubes P. Nitric oxide prevents leukocyte adherence: role of superoxide. Am J Physiol 1993; 265: H862-7

[16] Niu XF, Ibbotson G, Kubes P. A balance between nitric oxide and oxidants regulates mast cell-dependent neutrophil-endothelial cell interactions. Circ Res 1996; 79: 992-9.

[17] Kwasniewski FH, Tavares de Lima W, Bakhle YS, Jancar S. Endogenous nitric oxide does not modulate mesenteric mast cell degranulation in rats. Biochem Pharmacol 2003; 65: 2073-80.

[18] Peh KH, Moulson A, Wan BY, Assem EK, Pearce FL. Role of nitric oxide in histamine release from human basophils and rat peritoneal mast cells. Eur J Pharmacol 2001; 425: 229-38

[19] Brooks AC, Whelan CJ, Purcell WM. Reactive oxygen species generation and histamine release by activated mast cells: modulation by nitric oxide synthase inhibition. Br J Pharmacol 1999; 128 : 585-90.

[20] Kimura M, Mitani H, Bandoh T, Totsuka T, Hayashi S. Mast cell degranulation in rat mesenteric venule: effects of L-NAME, methylene blue and ketotifen. Pharmacol Res 1999; 39: 397-402

[21] Scalia R, Appel JZ 3rd, Lefer AM. Leukocyte-endothelium interaction during the early stages of hypercholesterolemia in the rabbit: role of P-selectin, ICAM-1, and VCAM-1. Arterioscler Thromb Vasc Biol 1998; 18: 1093-100

[22] Mitchell DJ, Yu J, TymL K. Local L-NAME decreases blood flow and increases leukocyte adhesion via CD18. Am J Physiol 1998; 274: $\mathrm{H} 1264-8$

23] De Caterina R, Libby P, Peng HB, Thannickal VJ, Rajavashisth TB, Gimbrone MA Jr et al. Nitric oxide decreases cytokine-induced endothelial activation. Nitric oxide selectively reduces endothelial expression of adhesion molecules and proinflammatory cytokines. J Clin Invest 1995; 96: 60-8.

[24] Adams MR, Jessup W, Hailstones D, Celermajer DS, L-arginine reduces human monocyte adhesion to vascular endothelium and endothelial expression of cell adhesion molecules. Circulation 1997; 95: 662-8.

[25] Hickey MJ. Role of inducible nitric oxide synthase in the regulation of leucocyte recruitment. Clin Sci (Lond) 2001: 100:1-12.

[26] Lee SK, Kim JH, Yang WS, Kim SB, Park SK, Park JS. Exogenous nitric oxide inhibits VCAM-1 expression in human peritoneal mesothelial cells. Role of cyclic GMP and NF-kappaB. Nephron 2002; 90: 447-54

[27] Selleri C, Maciejewski JP. Nitric oxide and cell survival: megakaryocytes say 'NO'. J Lab Clin Med 2001; 137: 225-30.
[28] Geffner JR, Trevani AS, de D'Elia I, Diament M, Klein D, Giordano $\mathrm{M}$. Involvement of nitric oxide in the regulation of peripheral blood leukocyte counts. J Leukoc Biol 1995; 58: $391-4$

[29] Lund-Johansen F, Terstappen LW. Differential surface expression of cell adhesion molecules during granulocyte maturation. J Leukoc Biol 1993; 54: 47-55.

[30] Mello SBV, Novaes GS, Laurindo IMM, Maciel FMB, Cossermelli W. NOS inhibition influences eicosanoids and Interleukin I production in experimental arthritic joint. Inflamm Res 1997; 46: $72-7$

[31] Guzzo ML, Farsky SH, De Nucci G, Antunes E, Silva MA, Mello SB. Role of kinins and nitric oxide on the rabbit arthritis induced by Bothrops jararaca venom. Toxicon 2000; 38: $1535-46$

[32] Mello SB, Guzzo ML, Lisboa LF, Farsky SH. Pharmacological characterisation of arthritis induced by Bothrops jararaca venom in rabbits: a positive cross talk between bradykinin, nitric oxide and prostaglandin E2. Mediators Inflamm 2002; 11: 13-6.

[33] Fortes ZB, Farsky SP, Oliveira MA, Garcia-Leme J. Direct vital microscopic study of defective leukocyte-endothelial interaction in diabetes mellitus. Diabetes 1991; 40: 1267-73.

[34] Farsky SP, Sannomiya P, Garcia-Leme J. Secreted glucocorticoids regulate leukocyte-endothelial interactions in inflammation. A direct vital microscopic study. J Leukoc Biol 1995; 57: 379-_86.

[35] Borders JL, Granger HJ. An optical doppler intravital velocimeter. Microvasc Res 1984; 27: 117-17.

[36] Davis MJ. Determination of volumetric flow in capillary tubes using an optical Doppler velocimeter. Microvasc. Res 1987; 34 : 223-30.

[37] Van Kampen EJ, Zijstra WG. Standardization of hemoglobinometry II. The hemoglobin cyanide methods. Clin Chem Acta 1961; 6 : $538-43$

[38] Brown BA. In: Lea, Febiger (Eds), Hematology, Principles and practice, Fourth Edition. Philadelphia, 1984

[39] Beckman JS, Koppenol WH. Nitric oxide, superoxide, and peroxynitrite: the good, the bad, and ugly. Am J Physiol 1996; 271 C1424-37.

[40] Halliwell B, Zhao K, Whiteman M. Nitric oxide and peroxynitrite. The ugly, the uglier and the not so good: a personal view of recent controversies. Free Radic Res 1999:31:651-69.

[41] Ribeiro MO, Antunes E, De Nucci G, Lovisolo SM, Zatz R Chronic inhibition of nitric oxide synthesis. A new model of arterial hypertension. Hypertension 1992; 20: 298-303

[42] Navarro J, Sanchez A, Saiz J, Ruilope LM, Garcia-Estan J, Romero JC et al. Hormonal, renal, and metabolic alterations during hypertension induced by chronic inhibition of $\mathrm{NO}$ in rats. Am J Physiol 1994; 267: R1516-21.

[43] Moreno H Jr, Piovesan NL, Pereira Costa SK, Metze K, Antunes E, Zatz R et al. Enalapril does not prevent the myocardial ischemia caused by the chronic inhibition of nitric oxide synthesis. Eur J Pharmacol. 1995; 287: 93-6

[44] De Gennaro Colonna V, Rossoni G, Rigamonti A, Bonomo S, Manfredi B, Berti F et al. Enalapril and quinapril improve endothelial vasodilator function and aortic eNOS gene expression in L-NAME-treated rats. Eur J Pharmacol 2002; 450: 61-6.

[45] Kubes P, Granger DN. Leukocyte-endothelial cell interactions evoked by mast cells. Cardiovasc Res 1996; 32: 699-708

[46] Yamaki K, Thorlacius H, Xie X, Lindbom L, Hedqvist P, Raud J. Characteristics of histamine-induced leukocyte rolling in the undisturbed microcirculation of the rat mesentery. $\mathrm{Br} \mathrm{J}$ Pharmacol 1998; 123: 390-9

[47] Baldwin AL, Thurston G, al Naemi H. Inhibition of nitric oxide synthesis increases venular permeability and alters endothelial actin cytoskeleton. Am J Physiol 1998; 274: H1776-84.

[48] Salvemini D, Manning PT, Zweifel BS, Seibert K, Connor J, Currie MG et al. Dual inhibition of nitric oxide and prostaglandin production contributes to the antiinflammatory properties of nitric oxide synthase inhibitors. J Clin Invest 1995b; 96:301-8.

[49] Paya M, Garcia PP, Coloma J, Alcaraz MJ. Nitric oxide synthase and cyclo-oxygenase pathways in the inflammatory response induced by zymosan in the rat air pouch. Br J Pharmacol 1997; 120: $1445-52$ 
[50] Gad MZ, Khattab M. Modulation of nitric oxide synthesis in inflammation. Relationship to oxygen-derived free radicals and prostaglandin synthesis. Arzneimittelforschung 2000; 50: 449-55

[51] Herencia F, Ferrandiz ML, Ubeda A, Guillen I, Dominguez $\mathrm{JN}$, Charris JE et al. 4-dimethylamino-3',4'-dimethoxychalcone downregulates iNOS expression and exerts anti-inflammatory effects. Free Radic Biol Med 2001; 30: 43-50.

[52] Kaplan SS, Billiar T, Curran RD, Zdziarski UE, Simmons RL, Basford RE. Inhibition of chemotaxis $\mathrm{Ng}$-monomethyl-L-arginine: a role for cyclic GMP. Blood 1989; 74: 1885-7.

[53] Belenky SN, Robbins RA, Rennard SI, Gossman GL, Nelson KJ, Rubinstein I. Inhibitors of nitric oxide synthase attenuate human neutrophil chemotaxis in vitro. J Lab Clin Med 1993; 122: 388 94.

[54] VanUffelen BE, de Koster B, Van den Broek MPJ, VanSteveninck J, Elferink JG. Modulation of neutrophil migration by exogenous gaseous nitric oxide. J Leukoc Biol 1996; 60: 94-100

[55] Zanardo RC, Costa E, Ferreira HH, Antunes E, Martins AR, Murad $\mathrm{F}$ et al. Pharmacological and immunohistochemical evidence for a functional nitric oxide synthase system in rat peritoneal eosinophils. Proc Natl Acad Sci USA 1997; 94: 14111-4.

[56] Biffl WL, Moore EE, Moore FA, Barnett C. Nitric oxide reduces endothelial expression of intercellular adhesion molecule (ICAM)-1. J Surg Res 1996; 63: 328-32.

[57] Takahashi M, Ikeda U, Masuyama J, Funayama H, Kano S, Shimada K. Nitric oxide attenuates adhesion molecule expression in human endothelial cells. Cytokine 1996; 8: 817-21.

[58] Lefer DJ, Jones SP, Girod WG, Baines A, Grisham MB, Cockrel AS et al. Leukocyte-endothelial cell interactions in nitric oxide synthase-deficient mice. Am J Physiol 1999; 276: H1943-50.
[59] Conran N, Gambero A, Ferreira HH, Antunes E, de Nucci G Nitric oxide has a role in regulating VLA-4-integrin expression on the human neutrophil cell surface. Biochem Pharmacol 2003;66. 43-50.

[60] Zhu J, Emerson SG. Hematopoietic cytokines, transcription factors and lineage commitment. Oncogene 2002; 21: 3295-313.

[61] Lotem J, Sachs L. Cytokine control of developmental programs in normal hematopoiesis and leukemia. Oncogene 2002; $21: 3284-94$

[62] Thomas J, Liu F, Link DC. Mechanisms of mobilization of hematopoietic progenitors with granulocyte colony-stimulating factor. Curr Opin Hematol 2002; 9 : 183-9.

[63] Selleri C, Sato T, Raiola AM, Rotoli B, Young NS, Maciejewski JP Induction of nitric oxide synthase is involved in the mechanism of Fas-mediated apoptosis in haemopoietic cells. $\mathrm{Br} \mathrm{J}$ Haematol 1997; 99: 481-9

[64] Maciejewski JP, Selleri C, Sato T, Cho HJ, Keefer LK, Nathan CF et al. Nitric oxide suppression of human hematopoiesis in vitro. Contribution to inhibitory action of interferon-gamma and tumor necrosis factor-alpha. J Clin Invest 1995; 96: 1085-92.

[65] Kansas GS, Muirhead MJ, Dailey MO. Expression of the CD11/CD18, leukocyte adhesion molecule 1, and CD44 adhesion molecules during normal myeloid and erythroid differentiation in humans. Blood; 1990; 76(12): 2483-92.

[66] Lund-Johansen F, Terstappen LW. Differential surface expression of cell adhesion molecules during granulocyte maturation. Leukoc Biol 1993; 54: 47-55.

[67] Terstappen LW, Gandour D, Huang S, Lund-Johansen F, Manion $\mathrm{K}$, Nguyen $\mathrm{M}$ et al. Assessment of hematopoietic cell differentiation by multidimensional flow cytometry. J Hematother 1993 2(3): $431-47$ 


\title{
On-Fiber Derivatization of SPME extracts of Phenol, Hydroquinone and Catechol with GC-MS Detection
}

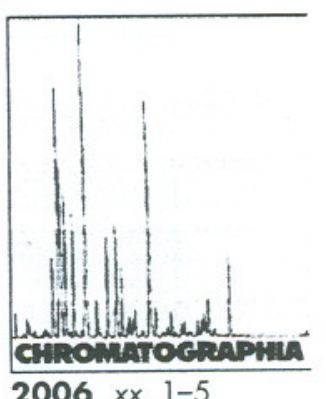

\author{
E. L. B. Lourenço ${ }^{1,2}$, A. Ferreira' ${ }^{1}$, E. Pinto' ${ }^{1}$, M. Yonamine ${ }^{1, \bigotimes}$, S. H. P. Farsky \\ 'Faculdade de Ciências Farmacêuticas, Universidade de Sáo Paulo-USP, Av. Prof. Lineu Prestes, 580 B-13B, CEP 05508-900, São Paulo-SP \\ Brazil; E-Mail: yonamine@usp.br \\ 2 Universidade Paranaense, UNIPAR, Praça Mascarenhas de Moraes, CEP 87500-000, Umuarama-PR, Brazi
}

Received: 23 September 2005 / Revised: 7 November 2005/ Accepted: 10 January 2006

Online publication:

\begin{abstract}
A gas chromatography-mass spectrometry (GC-MS) method for the simultaneous determination of phenol (PHE), hydroquinone (HQ) and catechol (CAT) in urine was developed and validated. The method was based on the acidic hydrolysis of conjugated phenolic compounds and further extraction of analytes using solid-phase microextraction (SPME). Analytes were extracted by submersing the polar polyacrylate coated fiber $(85 \mu \mathrm{m})$ into urine (adjusted to $\mathrm{pH} 3.0$ with glacial acetic acid) for $20 \mathrm{~min}$ with magnetic stirring. The extracted compounds on the fiber were exposed to hexamethyldisilazane reagent in the vapor phase for $20 \mathrm{~min}$ to yield the corresponding trimethysilitylated derivates. This on-fiber derivatization procedure allowed the formation of more amenable compounds for GC analysis, without adversely affecting the lifetime of the fiber. The MS was operated in the selected ion monitoring mode (SIM). The limits of detection were $0.3 \mu \mathrm{g} \mathrm{mL}^{-1}$ for PHE, $0.15 \mu \mathrm{g} \mathrm{mL}^{-1}$ for $\mathrm{HQ}$ and $0.02 \mu \mathrm{g} \mathrm{mL}^{-1}$ for CAT. Inter and intra-assay precisions were also verified (coefficient of variation $<8 \%$ ) with the use of deuterated internal standards. This method of GC-MS analysis can be readily utilized to monitor PHE and its metabolites (HQ and CAT) in urine samples.
\end{abstract}

\section{Keywords}

Gas chromatography-mass spectrometry

Solid-phase microextraction

On-fibre derivatisation

Phenol, hydroquinone and catechol

\section{Introduction}

Phenols are compounds frequently monitored in urine and other biological samples to obtain an indication of occupational exposure or exposure to environmental contamination $[1,2]$. Phenol (PHE) itself is a widely employed chemical and is associated with headache, fainting, vertigo, and mental disturbances [3]. As a raw industrial material, it is

Original widely used as a disinfectant, as an antiseptic, and in medicinal preparations such as mouthwash and sore throat lozenges. It is also a constituent of phenolic resins and employed in the manufacture of nylon and other synthetic fibers $[4,5]$.

PHE is absorbed into the human body following dermal, oral or inhalatory exposure and is extensively metabolized in the liver. Excretion is primarily through the urinary route, and therefore it can be found in urine either in its unaltered form or as biotransformed substances. Conjugation with glucuronic acid or sulphation is the major detoxification pathways for phenolic compounds, and consequently glucuronide and sulphate conjugates can also be found in urine. Additionally, PHE and more polar phenolic compounds such as hydroquinone (HQ) and catechol (CAT) are benzene metabolites. These substances are substrates for peroxidases present in the bone marrow and are responsible for the immunological and hematological toxic effects of benzene $[3,6,7,8]$.

Quantitative methods for the determination of PHE and its derivatives in urine have been described in the scientific literature using high-performance liquid chromatography (HPLC) $[9,10,11]$, capillary gas chromatography (GC) [12] and GC-MS $[4,13,14]$. For these applications, an extraction step is a necessary pre-requisite to isolate and pre-concentrate the analytes prior to chromatographic analysis.

Conventional liquid-liquid extraction (LLE) is the most frequently employed sample preparation technique used in the determination of phenolic compounds. However, it produces emulsions and sometimes requires an additional cleanup step which gives rise to further losses, as well as requiring large amounts of solvents and being a time-consuming and laborious technique as well [1]. Solid-phase extraction (SPE) has been extensively used for the analyses of organic compounds present in biological samples, which can be retained into the cartridges and eluted with an 

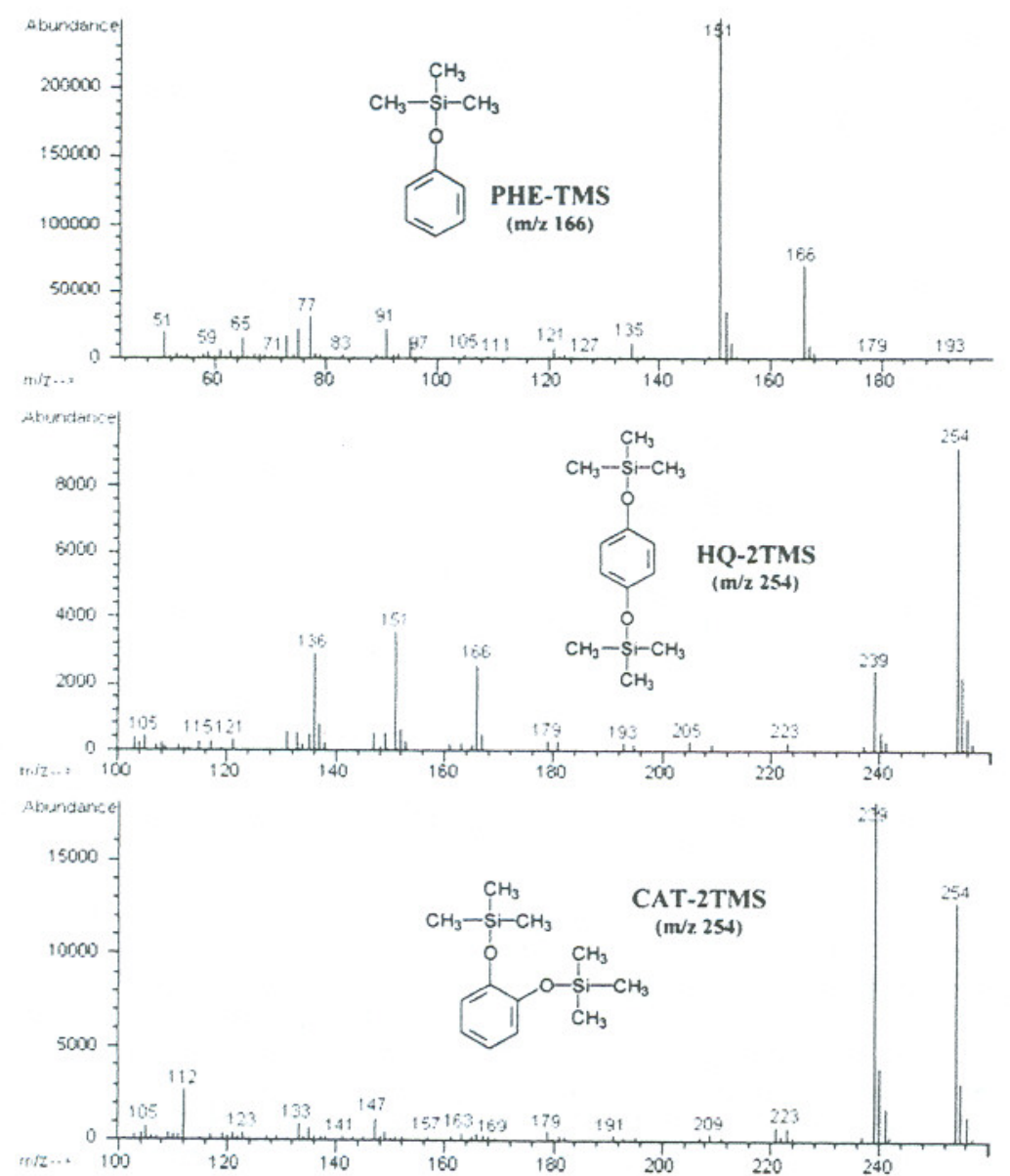

Fig. 1. Full scan mode mass spectra of the trimethylsilylated derivatives of phenol (PHE-TMS), hydroquinone (HQ-2TMS) and catechol (CAT-2TMS)

adequate solvent. However, SPE has some important limitations, since it is a multistep process and relatively high solvent volumes are necessary to clean up and elute the analytes $[1,4,15]$.

Recently, a simple, rapid and solventfree extraction technique has been developed. First introduced in 1990 by Arthur and Pawliszyn [16], solid-phase microextraction (SPME) does not require the use of an organic solvent for extraction. Nowadays, SPME has been widely used in a broad field of analyses, including the environmental, food and drug abuse areas [17]. The extraction efficiency is determined by the partitioning of analytes between the sample matrix and the solid-phase fiber coating. After a pre-determined extraction time, the fiber is placed into the injector port of gas chromatograph in order to strip the adsorbed substances [15, 18].
To our knowledge, SPME had never been employed for the determination of PHE and more polar metabolites in biological specimens. In the present work, an on-fiber derivatization method for the simultaneous analysis of PHE, HQ and CAT in urine was developed using SPME and GC-MS. The feasibility of applying this method was evaluated by investigating the limits of detection and quantification (LOD and LOQ), recovery values, linear dynamic ranges and reproducibility for the analytes.

\section{Experimental}

\section{Reagents and Reference Standards}

PHE (99.5\% purity), HQ $(99 \%)$ and catechol $(99 \%)$ were purchased from
Sigma (St. Louis, USA). Their respective deuterated-labeled analogues, PHE-d5 (98\%), CAT-d6 (98\%) and HQ-d6 (98\%) were purchased from Cambridge Isotope Laboratories (Andover, USA). The silylating reagent hexamethyldisilazane was obtained from Merck (Darmstadt, Germany). Other reagents of common use in the laboratory were of analytical grade purchased from Merck (Darmstadt, Germany).

\section{Preparation of Standard Solutions}

Working solutions of PHE, PHE-ds (PHE-d5), HQ, HQ-d6 (HQ-d6). CAT and catechol-d6 (CAT-d6) at a concentration of $1000 \mu \mathrm{g} \mathrm{mL}^{-1}$, and $100 \mu \mathrm{g}$ $\mathrm{mL}^{-1}$ were prepared with deionized water in volumetric glassware.

\section{Instrumentation}

Solid-phase microextraction (SPME) instrumentation were obtained from $\mathrm{Su}$ pelco (Bellefonte, PA, USA) equipped with $85 \mu \mathrm{m}$ polyacrylate coated fiber GC-MS analyses for PHE, HQ and CAT were performed using a gas chromatograph model 6890 coupled with a mass selective detector (MSD) model 5972 (Agilent Technologies Inc., Palo Alto. CA, USA). Chromatographic separation was achieved on a HP5-MS fused-silica capillary column $(30 \mathrm{~m} \times 0.25 \mathrm{~mm} \times$ $0.10 \mu \mathrm{m}$ film thickness) using helium carrier gas at $0.6 \mathrm{~mL} \mathrm{~min}^{-1}$ in a constant flow rate mode. The MSD was operated using electronic ionization $(70 \mathrm{eV})$ in selected ion monitoring (SIM) mode. The injector port and interface temperature was $250^{\circ} \mathrm{C}$. The injector was operated in splitless mode. The oven temperature was maintained at $50{ }^{\circ} \mathrm{C}$ for $2 \mathrm{~min}$, programmed at $13{ }^{\circ} \mathrm{C} \mathrm{min}-1$ to $250^{\circ} \mathrm{C}$ with a hold at $250^{\circ} \mathrm{C}$ for $5 \mathrm{~min}$. The following ions were chosen for SIM analyses (quantification ions underlined): PHE: 151, 152, 166; PHE-d5: 156, 171; HQ: 239, 240, 254; HQ-d6: 243, 258; CAT: 239, 240, 254; CAT-d6: 243, 258.

\section{Sample Preparation}

Urinary conjugated phenolic derivatives were hydrolyzed by concentrated hydrochloric acid by adding $0.1 \mathrm{~mL}$ of 
A
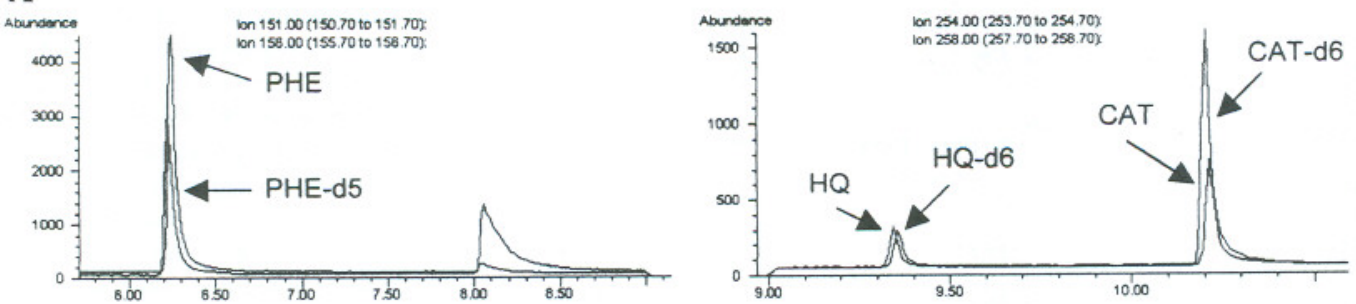

B
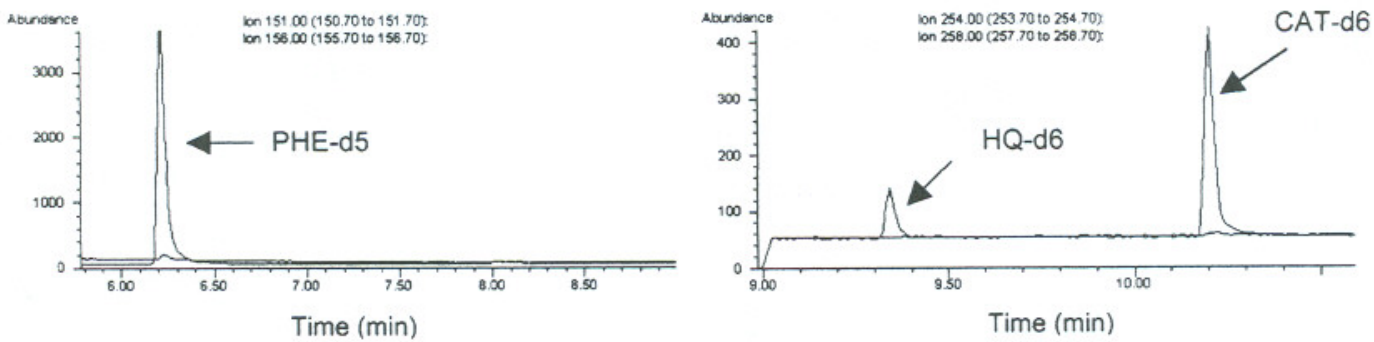

Fig. 2 A Chromatographic profiles obtained with the SPME and GC-MS analysis of a spiked urine sample containing $10 \mu \mathrm{g} \mathrm{mL}{ }^{-1}$ of phenol (PHE). hydroquinone (HQ) and catechol (CAT) and B Blank sample. Chromatographic separation was achieved on a HP5-MS fused-silica capillary column $\left(30 \mathrm{~m} \times 0.25 \mathrm{~mm} \times 0.10 \mu \mathrm{m}\right.$ film thickness) using helium as carrier gas at $0.6 \mathrm{~mL} \mathrm{~min}^{-1}$ in a constant flow rate mode. The oven temperature was maintained at $50{ }^{\circ} \mathrm{C}$ for 2 min, programmed at $13{ }^{\circ} \mathrm{C} \mathrm{min}-1$ to $250{ }^{\circ} \mathrm{C}$ with a hold at $250{ }^{\circ} \mathrm{C}$ for $5 \mathrm{~min}$

concentrated $\mathrm{HCl}$ to $1.0 \mathrm{~mL}$ of urine sample. The solution was heated for $90 \mathrm{~min}$ at $95^{\circ} \mathrm{C}$. After cooling, deuterated internal standards of PHE-d5 $(5 \mu \mathrm{g})$, HQ-d6 $(10 \mu \mathrm{g})$ and CAT-d6 $(10 \mu \mathrm{g})$ were added. Afterwards, the solution was neutralized with approximately $0.27 \mathrm{~mL}$ of $\mathrm{KOH} 5 \mathrm{M}$ and the volume was completed to $2 \mathrm{~mL}$ with deionized water. The solution was acidified with $0.1 \mathrm{~mL}$ of glacial acetic acid to adjust $\mathrm{pH}$ to approximately 3.0. Analytes were extracted using SPME, dipping an $85 \mu \mathrm{m}$ polyacrylate fiber into solution for 20 min with magnetic stirring to obtain an optimal exchange surface. Extraction was performed at room temperature (20 $\pm 3^{\circ} \mathrm{C}$ ). After the extraction time, the fiber was immediately exposed to the headspace (vapor phase) over $100 \mu \mathrm{L}$ of hexamethyldisilazane reagent (heated to $80^{\circ} \mathrm{C}$ ) for $20 \mathrm{~min}$ and the SPME device was then directly inserted into the GC injector port at $250^{\circ} \mathrm{C}$ for a $20 \mathrm{~min}$ desorption. The derivatization step with hexamethyldisilazane converts PHE, HQ, CAT and their respective deuterated internal standards to corresponding trimethylsilyl-ethers prior to GC-MS analysis. Mass spectra in full scan mode of trimethylsilylated derivatives are shown in Fig. 1.

\section{Validation of the Method}

Validation of the method was carried out to establish recovery values, linearity, intra- and inter-assay precision, limits of detection (LOD) and quantification (LOQ). Negative urine samples, used in these studies, were prepared as follows: urine samples were added with $10 \%$ of concentrated hydrochloric acid and boiled until complete evaporation of water. Afterwards, the residue was ressuspended with the same volume of deionized water. This procedure was performed to eliminate any $\mathrm{PHE}$ contents present in urine.

\section{Recovery}

The recovery studies for PHE, HQ and CAT were performed taking into consideration the possible loss of the analytes by thermal decomposition after the hydrolysis procedure. For this study, two set of samples of different concentrations were analyzed. Set A consisted of three concentrations for all substances $(5.0 ; 20$ and $40 \mu \mathrm{g} \mathrm{mL}^{-1}$ ) and they were analyzed, according to the method described above, in six replicates for each concentration (processed). Set B also consisted of six replicates for each concentration $(5.0 ; 20$ and $40 \mu \mathrm{g} \mathrm{mL}^{-1}$ ) and the standard solutions (PHE, HQ and CAT) were spiked to the sample after the hydrolysis procedure (unprocessed). The absolute recovery was evaluated by comparison of the mean response obtained for set A (processed) and the response of set B (unprocessed). The unprocessed response represented $100 \%$ recovery.

\section{Linearity}

The study of linearity was carried out by the analysis of urine samples in triplicate submitted to the method with the following concentrations for PHE, HQ and CAT: (LOQ; $8.0 ; 15 ; 30 ; 60 ; 100 \mu \mathrm{g}$ $\mathrm{mL}^{-1}$ ).

\section{Intra-Day and Inter-Day Precision}

Precision, defined as the relative standard deviation or coefficient of variation $(\mathrm{CV})$, was determined by intra- and inter-day repetitions. This was performed by analyzing urine samples (quality controls) on three different days at the following concentrations for PHE. HQ and CAT: $5.0 ; 20$ and $40 \mu \mathrm{g} \mathrm{mL}^{-1}$. Six 
Table 1. Confidence parameters of the validated method for the determination of phenol. hydroquinone and catechol in urine samples

\begin{tabular}{|lccc|}
\hline & Phenol & Hydroquinone & Catechol \\
\hline Recovery $(\%)$ & & & \\
QC1 & 85.10 & 92.50 & 89.70 \\
QC2 & 76.40 & 77.20 & 81.30 \\
QC3 & 86.70 & 85.60 & 80.30 \\
LOD $\left(\mu \mathrm{g} \mathrm{mL}^{-1}\right)$ & 0.30 & 0.15 & 0.02 \\
LOQ $\left(\mu \mathrm{g} \mathrm{m}^{-1}\right)$ & 0.50 & 0.40 & 0.10 \\
Intra-assay precision $(\mathrm{CV} \%)$ & & & \\
QC1 & 3.30 & 7.20 & 6.60 \\
QC2 & 3.90 & 4.20 & 5.70 \\
QC3 & 3.90 & 7.20 & 7.80 \\
Inter-assay precision $(\mathrm{CV} \%)$ & & & \\
QC1 & 3.50 & 4.90 & 2.60 \\
QC2 & 1.00 & 2.30 & 1.00 \\
QC3 & 3.70 & 1.40 & 2.40 \\
\hline
\end{tabular}

$\mathrm{LOD}=$ limit of detection: $\mathrm{LOQ}=$ limit of quantification; $\mathrm{QCl}=5.0 \mu \mathrm{g} \mathrm{mL} \mathrm{L}^{-1} ; \mathrm{QC} 2=20 \mu \mathrm{g} \mathrm{m} \mathrm{L}^{-1}$; $\mathrm{QC} 3=40 \mu \mathrm{g} \mathrm{mL}$

replicates analyses were performed for each concentration.

\section{Limit of Detection (LOD) and Limit of Quantification (LOQ)}

The LOD was considered to be the concentration that produced a signal-tonoise ratio of about $3: 1$ and the LOQ was considered to be the concentration that produced a signal-to-noise ratio of about 10:1. The LOD and LOQ should still satisfy the predetermined acceptance criteria of qualification (retention time within $1 \%$ of standards and ion ratios within $20 \%$ ).

\section{Results and Discussion}

Several methods have previously been proposed to quantify phenols in urine, however, none of them employed solid phase microextraction (SPME) for the simultaneous determination of PHE and more polar phenolic metabolites, such as HQ and CAT. Data herein describes an analytical method using SPME and GCMS for quantification of three phenolic compounds in urine.

LLE or SPE have been used for determination of PHE, HQ and CAT in urine [4, 12, 13]. Recently, solid-phase microextraction (SPME), a relatively new technique, has gained considerable interest in a broad field of analysis [15, 18]. All steps of the conventional liquid-liquid extraction (LLE) such as extraction, concentration, derivatization and transfer to the chromatograph are integrated into one device, considerably simplifying the sample preparation technique. In the present method, over 20 urine samples could be extracted, injected and analyzed by one person in approximately $8 \mathrm{~h}$. The polar polyacrylate fiber was shown to be suitable to extract phenolic compounds in urine. Here, more than a hundred injections could be performed with the same fiber.

Before the extraction procedure of the analytes, a hydrolysis step was necessary because PHE and its derivatives are ex creted as glucuronide or sulphate conjugates in urine. In these cases, acidic and enzymatic hydrolyses are the chosen techniques. We favored acidic hydrolysis with the use of concentrated hydrochloric acid and incubation of samples at $95^{\circ} \mathrm{C}$ for $90 \mathrm{~min}$ because enzymatic hydrolysis, largely employed $[9,20]$, is hampered by the long time required for complete hydrolysis of phenolic compounds [21]

The acidic protons present on PHE, $\mathrm{HQ}$ and CAT require a chemical derivatization step before chromatographic analyses. Most derivatization procedures use acetylation, alkylation and silylation to block the active protons in phenolic hydroxyl group $[13,14,22]$. The formation and extraction of derivatives in the aqueous solution by a single-step procedure would be highly desirable. Nevertheless, the aqueous acetylation with acetic anhydride according to the method described by Llompart et al. [23] is not suitable for HQ and CAT since they are prone to oxidative degradation at a $\mathrm{pH}$ above eight [22]. Hence, a SPME step followed by an on-fiber derivatization procedure was necessary. Acetic anhydride was also used as a reagent to produce acetylated derivatives of $\mathrm{PHE}$
HQ and CAT in our initial experiments with on-fiber derivatization. The reaction was demonstrated to have a high success rate, however after only 4-6 derivatizations, the coating of the fiber was stripped off. Probably, the derivatizing reagent chemically attacked the epoxy that holds the fiber. This problem was solved with the use of hexamethyldisilazane, which promoted a rapid conversion of the phenolic compounds to trimethylsilyl derivatives, without dam. aging the fiber (Fig. 1).

Chromatograms obtained with the practical use of SPME and GC-MS analyses of urine samples are shown in Fig. 2. For this purpose, a blank sample was employed (PHE was excluded by adding $10 \%$ of concentrated hydrochloric acid and further boiled until complete evaporation of water) along with a sample spiked with PHE, HQ and CAT at the concentration of $10 \mu \mathrm{g} \mathrm{mL}^{-1}$ each.

The calibration curves were linear over the specified range for all analytes (PHE from 0.5 to $100 \mu \mathrm{g} \mathrm{mL}^{-1}$; HQ from 0.4 to $100 \mu \mathrm{g} \mathrm{mL}^{-1}$; CAT from 0.1 to $\left.100 \mu \mathrm{g} \mathrm{mL}^{-1}\right)$. The linear regression equations and coefficients of correlation were: $Y=0.184 X-0.183 ; r^{2}=0.998$ (PHE): $Y=0.123 X+0.099 ; r^{2}=0.999$ (HQ), and $Y=0.129-0.377 ; r^{2}=0.987$ (CAT), where $\mathrm{Y}$ and $\mathrm{X}$ represents the relationship between the peak area ratio (compound/internal standard) and the corresponding calibration concentration. respectively.

The confidence parameters of the validated method (LOD, LOQ, intra- and inter-assay precision and recoveries) are shown in Table 1. The internal standards (IS's) employed were with deuteriumlabeling in the aromatic ring. For this reason, the ions chosen were 5,4 and 4 a.m.u. higher than the non-labeled PHE, HQ and CAT, respectively. The analytical technique developed for the determination of PHE, HQ and CAT in urine with the use of respective deuterated IS's provided better precision ( $\mathrm{CV}$ $<8 \%$ ) than previous published methods $[11,13](\mathrm{CV}<17 \%)$. The sensitivity was equivalent for all analytes if compared with the method proposed by Marrubini et al. [11].

\section{Conclusion}

As far as we know, this is the first report dealing with an on-fiber derivatization 
method for the determination of PHE, HQ and CAT in urine samples. It is demonstrated that these compounds could be isolated from urine samples by SPME and sensitively quantified using the SIM mode with GC-MS. Hence, this methodology could be an efficient tool to follow phenol kinetics in several toxicological studies.

\section{Acknowledgments}

Financial support from Fundação de Amparo à Pesquisa do Estado de São Paulo (FAPESP grant $n^{\circ} 03 / 04013-8$ ) is gratefully acknowledged. Emerson Luiz Botelho Lourenço and Alexandre Ferreira are graduate fellows. Alexandre Ferreira is fellow of FAPESP $\left(\mathrm{n}^{\circ} 04\right.$ 11412-9). The authors thank Dr. Paul Gates (School of Chemistry, University of Bristol, UK) for the English revision.

\section{References}

1. Lee MR, Yeh YC, Hsiang WS, Chen CC (1998) J Chromatogr B 707:91-7.

2. Khoschsorur GA, Petek W (2000) Anal Sci 16:589-91.

3. Bruce W, Meek ME, Newhook R (2001) J Environ Sci Heal C. 19:305-24.

4. Crespin MA. Gallego M. Valcarcel M (2002) J Chromatography B 773:89-96.

5. www.oehha.ca.gov/air/chronic_rels/pdf/ 108952.pdf.

6. Irons RD (1985) J Toxicol Environ Health 16:673-8.

7. Smith MT. Yager JW, Steinmetz KL, Eastmond DA (1989) Environ Health Perspect 82:23-9.

8. Snyder R (2004) Drug Metab Rev 36:53!-47. 9. Schad H, Schafer F, Weber L, Seidel HJ (1992) J Chromatogr 593:147-51.

10. Lee BL, Ong HH, Shi CY, Ong CN (1993) J Chromatogr 619:259-66.

11. Marrubini G, Calleri E, Coccini T, Castoldi AF. Manzo L (2005) Chromatographia 62:25-31.

12. Ong $C N$, Lee BL, Ong HY. Heng LF (1988) J Anal Toxicol 12:159-61.
13. Waidyanatha S, Rothman N, Li G, Smith MT, Yin S, Rappaport SM (2004) Analytical Biochemistry 327:184-99

14. Laurens JB, Mbianda XY. Spies JH Ubbink JB, Vermaak WJ (2002) J Chromatogr B 774:173-85.

15. Vas G, Vekey, K (2004) J Mass Spectrom 39:233-54. DOI: 10.1002/jms.606.

16. Arthur CL, Pawliszyn J (1990) Anal Chem 62:2145-48

17. Yonamine M. Tawil N, Moreau RLM Silva OA (2003) 789:73-8.

18. Lord H, Pawliszyn J (2000) J Chromatogr A 902:17-63.

19. Agozzino P, Avellone G, Boscaino G. Miceli S (1999) J Mass Spectrom 34:1 383-4

20. Wittig J, Wittemer S, Veit M (200) J Chromatogr B 76!:125-32.

21. Ong CN, Lee BL (1994) J Chromatography B $660: 1-22$.

22. Kim KR, Kim H (2000) J Chromatogr A 866:87-96.

23. Llompart $M$, Lourido $M$, Landin $P$, Garcia-Jares C, Cela R (2002) J Chromatogr A 963:137-48. 
Anexo 7. Trabalho apresentado: MACEDO, S.M.; LOURENÇO, E.L.; BORELLI, P.; FOCK, exposure on events related to neutrophil delivery during an inflammatory response. Toxicology, 2006.

\title{
Effect of in vivo phenol or hydroquinone exposure on events related to neutrophil delivery during an inflammatory response
}

\author{
S.M.D. Macedo ${ }^{a, b}$, E.L.B. Lourenço ${ }^{a, c}$, P. Borelli ${ }^{a}$, R.A. Fock ${ }^{a}$, \\ J.M. Ferreira Jr. ${ }^{\mathrm{d}}$, S.H.P. Farsky ${ }^{\mathrm{a}, *}$ \\ ${ }^{a}$ Department of Clinical and Toxicological Analysis, School of Pharmaceutical Sciences, University of São Paulo, \\ Av. Prof. Lineu Prestes, 580 Bl 13 B. São Paulo 05503-900, Brazil \\ ${ }^{b}$ Department of Health Sciences, Regional Integrated University of Alto Uruguai and Missñes, Erechim, Brazil \\ 'Paranaense University, Umuarama, Brazil \\ 'Immunochemistry Lab, Butantan Institute, São Paulo, Brazil
}

Received 22 September 2005; received in revised form 8 December 2005; accepted 15 December 2005

Abstract

Phenol (PHE) and hydroquinone (HQ) are metabolites of benzene that affect leukocytes after solvent intoxication. Hence, we investigated the effects of PHE or HQ exposure on neutrophil mobilization during an inflammatory response. Male Wistar rats received intraperitoneal injections of $\mathrm{PHE}, \mathrm{HQ}$ or vehicle only and assays were performed $24 \mathrm{~h}$ after the last dose. Quantifications of bone marrow or circulating leukocytes showed that only HQ exposure induced neutrophilia, probably due to the accelerated mobilization from the bone marrow compartment, since reduced numbers of segmented cells in the last phase of maturation were detected there. Interracial microscopy showed that circulating leukocytes of HQ-exposed rats increased their rolling behavior and adherence to the mesenteric postcapillary venule wall in vivo. The enhanced leukocyte-endothelium interaction was not dependent on microvascular reactivity or perivascular mast cell degranulation. Instead, it was the result of neutrophil activation, demonstrated by a decrease in L-selectin and an increase in $\beta_{2}$ integrin expression on neutrophil membranes. This pattern of neutrophil activation may have contributed to the higher number of neutrophils in the subcutaneous inflammatory response of HQ-exposed rats after oyster glycogen injection. Taken together, our results indicate that HQ exposure alters neutrophil mobilization, which results in an exacerbated response after an injury. Although PHE is endogenously metabolized to HQ, PHE exposure only induced an increment in rolling behavior, which was not sufficient to alter the inflammatory response.

(C) 2005 Published by Elsevier Ireland Ltd.

Keywords: Phenol; Hydroquinone; Inflammation; Leukocyte-endothelial interaction; Adhesion molecules

\section{Introduction}

Human exposure to phenolic compounds can occur in the environment, occupationally, through diet, cosmetics, medicines and cigarette-smoke (Ong et al.. 1994: Duarte-Davidson et al.. 2001; ( heynier. 2005). These

- Corresponding author. Tel.: +55 1130912197 ; fax: +551138156593 .

E-mail address: sfarsky@usp.br (S.H.P. Farsky). highly reactive compounds are substrates to various enzymes, including polyphenoloxidases, peroxidases, 
+ Model

glycosidases and esterases (Cheynier. 2005). For this reason, their pharmacological and toxic effects are varied and complex.

Two such compounds, phenol (PHE) and hydroquinone (HQ), are reactive metabolites from benzene biotransformation and are responsible for serious effects of solvent intoxication (Schrenk et al.. 1996: Snyder. 20000. 2002. 2004). After pulmonary or dermal absorption, benzene is oxidized in the liver by cytochrome P450 2E1 to form benzene epoxide, which can be either conjugated to ring-opened metabolites or transformed into PHE and catechol. Moreover, CYP450 enzymes convert PHE and catechol to HQ and 1,2,4-benzenetriol, respectively (Goldstem et at. 1982: Snvder. 20022.2014). The ability of these circulating phenolic compounds to easily penetrate into the bone marrow compartment and be locally metabolized and accumulated contributes in an important way to the myelotoxicity in benzene intoxication (Henderson. 1996: Snyder. 2002. 2004). In the bone marrow, these compounds are auto-oxidized or further oxidized via reactions mediated by peroxidases, such as myeloperoxidase, to their highly active quinone and semiquinone derivates (Schlosser and Kall. 1989. Schlonier et al. I(x)in).

The effects of PHE or HQ administration on mononuclear leukocytes are detected even in stem cells in the bone marrow microenvironment and in distinct phases of maturation and proliferation (1.i ef al. 1996: Pyan et at. 1998. 2000): Stillman et at., 2000\%: Smith et al. 2006: Doepker et al. 2000): Kalf. 2000: Poirier et al. 2002: Ve (ue et al, 2003). The consequent reduced number and activity of $\mathrm{B}$ and $\mathrm{T}$ lymphocytes contribute to leukemia and immunossupressive effects (Snyder. 2002. 2004 ). Conversely, PHE and HQ may stimulate granulocyte production. Previous studies demonstrated an increase in the number of granulocyte-macrophage progenitor cells in the bone marrow of mice pre-treated with HQ and an increased proliferation of murine multipotent hematopoietic progenitor cells in vitro. Addition of PHE to HQ generated even larger effects (Hayel et al. 1996a; Henschler et al.. 1996). Furthermore. it has been shown in vitro that low concentrations of HQ induce terminal granulocytic differentiation in murine myeloblasts and inhibit apoptosis at the myeloblasts/myelocyte stage of differentiation ( Hayel and Kalf. 1996: Hazel et at., 19966). Although the mechanisms involved are not totally understood, influence on growth-stimulating factors, such as granulocytemacrophage colony-stimulating factor and IL-3, and leukotriene D4 receptor has been suggested (Hwel et 4.. Hoga, 1996b: Harel and Kalf. 1996: Wiemels and Simsth, (wo9).
Effective mobilization of leukocytes to the site of injury is crucial for the host defense against infections. At the early stages of an acute inflammatory response. neutrophils are mobilized from the bone marrow or peripheral compartments to the blood and to the site of lesion, respectively. Circulating cells initially roll and adhere to the endothelium from postcapillary venules of the microcirculatory network and subsequently transmigrate into the extravascular space and move directly to the site of inflammation. The rolling and adherence of leukocytes on endothelium of postcapillary venules is influenced by events that alter hemodynamic parameters, such as vascular reactivity, which can modify the blood flow at the site of inflammation, and by endogenous mediators, which trigger cellular interactions. In this context, constitutive mast cells neighboring postcapillary venules release starter chemicals that induce the rolling behavior (Salazar-Mather and Hokeness. 2003. Sallusto and Mackay. 2004). A coordinated interplay involving a spectrum of adhesion molecules successively expressed on cellular membranes mediates the interactions in the microvasculature and the extravascular tissue (Granger and Kubes, 1994: Steeher and Tedder. 2000. Bochner. 2004: Steeher el ai.. 2015).

It has been extensively demonstrated that the adhesion molecule L-selectin, constitutively expressed in leukocytes, mediates the rolling behavior through the interaction with sialylated carbohydrate determinants on the endothelial membrane (Cambi and Figdor. 2003: Rosen. 2004). After activation, L-selectin undergoes ectodomain cleavage, resulting in its intermittent expression. The significance of L-selectin endoproteolytic shedding was experimentally verified by an increased recruitment of neutrophils to the inflamed area (Veniuri el al. 2003). The stronger cellular interaction during subsequent adhesion is mediated by $\beta_{2}$ integrin molecules on activated leukocytes, which bind to molecules of the immunoglobulin superfamily on the endothelium (Hubbard and Rothlein, 2000); Hogg et al. 2002). The sequential expression of adhesion molecules on leukocyte trafficking is linked to the ability of rolling leukocytes and endothelial cells to sense signals, which stimulate cellular events responsible for firm adherence to the vessel wall surface. Such signals can be given by endogenous mediators, which are secreted by immune competent cells on the vessel wall or on the adjacent tissue of the microcirculatory network of an inflamed area (Fibnet and vestweber. 1999. Kin et al. 2004: Kuldo et al. 2005). Recent studies have suggested that adhesion molecule interactions induce a bidirectional signaling between leukocytes and the endothelium, which mediate events that facilitate the onward migration of 
Anexo 7. Trabalho apresentado: MACEDO, S.M.; LOURENÇO, E.L.; BORELLI, P.; FOCK,

leukocytes through venule walls, as well as their responsiveness. behavior, differentiation state and survival at inflammation sites (Huhbard and Rothlein. 2000; Wang 5 and Doerschuk. 2002; Kluger. 2004; Nourshargh and Marelli-Berg, 2005).

Despite abundant descriptions of the effect of PHE and/or HQ on neutrophil production or maturation in vivo, the effect of these substances on neutrophil recruitment to different compartments has not yet been reported. Therefore, in this study we evaluated the consequence of a 17-day exposure to PHE or HQ in vivo on cellular events involved in the phases of neutrophil mobilization. In addition, the outcome of the altered mechanisms detected in neutrophils was investigated after an acute inflammatory response. Our data also indicate that although PHE is endogenously transformed into HQ, PHE exposure did not alter the mechanisms involved in neutrophil distribution and the inflammatory process.

130 2. Materials and methods

:31 2.1. Chemicals

PHE (Merck, Darmstadt, Germany), pentobarbital sodium (Cristália, São Paulo, Brazil), cellulose ester filter $0.25 \mu \mathrm{m}$ (Millipore, Sao Paulo, Brazil), FITC-labeled monoclonal antirat CD62L (L-selectin, LECAM-1) and FITC-labeled mon136 oclonal anti-rat CD18 ( $\beta_{2}$ integrin; BD Pharmingen, San 137 Diego, CA, USA), heparin (Liquemine ${ }^{\star}$, Roche), oyster glyco${ }_{38}$ gen (Type II), EDTA, HQ, noradrenaline (NA), acetylcholine

39 (Ach), compound 48/80 and McCoy's 5A medium (Sigma, St. 40 Louis, MO, USA).

\subsection{Animals}

Adult male Wistar rats weighing 180-220 g were used. Aniallowed a standard pellet diet and water ad libitum. All animal procedures were performed according to approved protocols and in accordance with recommendations for the proper use and care of laboratory animals. At the time of the experimental 48 assays, animals were anaesthetized with pentobarbital sodium 49 (65 mg/kg; intraperitoneally).

\section{2.3. Protocols of exposure}

PHE or HQ $(50 \mathrm{mg} / \mathrm{kg}$ in a final volume of $1 \mathrm{ml})$ was intraperitoneally injected into the rats once a day. The animals received 13 injections, daily on Days $1-5,8-12$ and 15-17. Assays were carried out on Day 18, $24 \mathrm{~h}$ after the last injection with each phenolic agent. Control rats received the same amount of vehicle through the same route. PHE or HQ was dissolved in absolute ethanol ( $5 \%$ of the final solution) and the volume was completed with sterile saline solution. Body weight was determined before and after the exposure to assess tolerance. The gain of corporal mass was equivalent in the three groups of animals studied (PHE $=107.8 \pm 4.89$. $\mathrm{HQ}=104.5 \pm 10.14$ and Vehicle $=105.6 \pm 8.13, n=36$ animals for each group).

\subsection{Quantification of bone marrow and circulating leukocytes}

Numbers of bone marrow and circulating leukocytes after chemical exposure were determined $24 \mathrm{~h}$ after the last injection. For circulating leukocytes, we obtained blood samples from the abdominal aorta using EDTA $(100 \mathrm{mg} / \mathrm{mL})$ as anticoagulant. Bone marrow leukocytes were obtained by flushing the femoral cavity with McCoy's 5A medium and with EDTA $(100 \mathrm{mg} / \mathrm{mL})$. The total number of leukocytes was assessed using a Neubauer chamber. Differential counts were performed on the basis of 500 cells per slide in cytocentrifuge smears stained with May-Grünwald and Giemsa dyes.

\subsection{Intravital microscopy assay}

Rats were anesthetized intraperitoneally with pentobarbital sodium $(65 \mathrm{mg} / \mathrm{kg})$ and the mesentery was exteriorized. After surgery, the animals were kept on a special board thermostatically controlled at $37^{\circ} \mathrm{C}$, which included a transparent platform on which the tissue to be transilluminated was placed. The preparation was kept moist and warmed by irrigating the tissue with a warmed Ringer-Locke solution $(\mathrm{pH} 7.2-7.4 ; \mathrm{NaCl}$ $154 \mathrm{mM} ; \mathrm{KCl} 5.6 \mathrm{mM} ; \mathrm{CaCl}_{2} \cdot 2 \mathrm{H}_{2} \mathrm{O} 2 \mathrm{mM} ; \mathrm{NaHCO}_{3} 6 \mathrm{mM}$ and glucose $5 \mathrm{mM}$ ) containing $1 \%$ gelatine. The rate of outflow of the solution onto the exposed tissue was controlled to keep the preparation in continuous contact with a film of the liquid. Transilluminated images were obtained by optical microscopy (Axioplan II, Carl-Zeiss equipped with $\times 5.0 / 0.30$ plan-neofluar or $\times 10.0 / 0.25$ Achroplan longitudinal distance objectives/numeric aperture and $\times 1.0,1.25$ or 1.60 optovar) The images were captured by a video camera (ZVS, 3C75DE Carl-Zeiss) and were transmitted simultaneously to a TV monitor and a computer. Images obtained on the TV monitor were recorded on video-tape. Digitized images on the computer monitor were subsequently analyzed by an image-analyzing software (KS 300, Kontron).

\subsubsection{Leukocyte-endothelial interaction}

The interaction between leukocytes and vessel walls was evaluated by determining the number of rolling and adhered leukocytes on the postcapillary venule wall $(20-30 \mu \mathrm{m}$ diameter, $200 \mu \mathrm{m}$ length) of the mesentery at 10-min intervals. Three fields from each animal were evaluated. Leukocytes moving in the peripheral of the axial stream, in contact with the endothelium, were considered to be rollers. These leukocytes moved sufficiently slowly to be individually visible and were counted as they rolled past a selected point on one side of the vessel. The number of leukocytes adhering to the endothelium (stopped at the vessel wall) was determined at the same vascular segment (Dahlen et al.. 1981; Fortes ef a1., 1991: Farky at al. 1995. 2(604) 


\title{
Toxicology, 2006.
}

\author{
+ Model
}

S.M.D. Macedo et al. / Toxicology $x x x(2006) x x x-x x x$

\section{2.6. Blood flow cytometry}

In order to quantify L-selectin or $\beta_{2}$ integrin expression, we isolated leukocytes from blood collected from the abdom.98 inal aorta (EDTA, $100 \mathrm{mg} / \mathrm{mL}$ ). Briefly, erythrocyte lysis was 9 performed using an ammonium chloride solution $(0.13 \mathrm{M})$ and 240 leukocytes were recovered after washing with HBSS. Cells 24. $\left(1 \times 10^{6}\right)$ were incubated with or without $N$-formyl-methionyl${ }^{242}$ leucyl-phenylalanine (fMLP; $10^{-8} \mathrm{M}$ for 10 or $30 \mathrm{~min}$ ). After 243 washing, leukocytes were further incubated for $30 \mathrm{~min}$ at $4{ }^{\circ} \mathrm{C}$ ${ }_{244}$ in the dark with $10 \mu \mathrm{L}$ of monoclonal antibody against $\mathrm{L}$ 245 selectin or $\beta_{2}$ integrin. Immediately after incubation, cells were 24 analyzed on a FACScalibur flow cytometer (Becton \& Dickin${ }_{247}$ son, San Jose, CA, USA). Data from 10,000 cells were obtained ${ }_{248}$ and only morphologically viable leukocytes were considered 249 for analysis. The cytometer separated leukocytes by size and 250 granulosity. As circulating leukocytes in rats are represented by lymphocytes (about $80-85 \%$ ), neutrophils (about 10-15\%), 252 monocytes (about 4-5\%), eosinophils (about 1\%), gates were 253 selected as mononuclear (lymphocytes and monocytes) and 254 polymorphonuclear (neutrophils and eosinophils) (farkis ot 255 . 21. 2014). Fluorescence intensity was obtained by median of 256 gated cells and results express the mean of four assays, per257 formed in duplicate.

258 2.7. In vivo neutrophil migration: Air Pouch model

Animals were anaesthetized with pentobarbital sodium $(65 \mathrm{mg} / \mathrm{kg}$; intraperitoneally) and $20 \mathrm{~mL}$ of sterile air were subcutaneously injected on the 8th day of chemical treatment. After 7 days, the pouch was upheld with approximately $5 \mathrm{~mL}$ of air. This procedure was described by Fitward et at. 1984 .
On the 10th day following the first injection of arr, oyster glycogen ( $5 \%$ in saline solution, $1 \mathrm{~mL}$ ) was injected into the pouch. Six hours later, the animals were again anesthetized and later sacrificed. The pouches were washed with $4 \mathrm{~mL}$ of PBS/heparin $(5 \mathrm{UL} / \mathrm{mL})$ and the total numbers of leukocytes in the collected exudate were determined in Neubauer chambers. Differential cell counts were performed using smears stained with Giemsa dye.

\subsection{Statistical analysis}

Means and standard errors of means (S.E.M.) of all data are presented and were compared using Student's $t$-test or ANOVA with a significance of less than 0.05 . Individual comparisons were subsequently carried out with Bonferroni's $t$-test for unpaired values and with Tukey test.

\section{Results}

\subsection{Numbers of circulating leukocytes}

To investigate if chemical exposure resulted in altered leucogram, leukocyte numbers were quantified in blood collected from control, PHE- or HQ-exposed rats. As seen in Fig. 1, the total number of leukocytes in PHEor HQ-exposed rats was equivalent to that from control animals. In addition, differential analysis demonstrated that HQ exposure did not modify the number of lymphocytes or monocytes, but resulted in an increase in the number of circulating neutrophils compared to control rats. PHE exposure did not modify the number of any type of peripheral white cells (Fig. I).

\subsection{Production and maturation of neutrophils in} the bone marrow

The effects of chemical exposure on neutrophil production or maturation were evaluated by bone marrow cellularity $24 \mathrm{~h}$ after the last injection of HQ or PHE. Our data demonstrate that neither exposure altered leukocyte production, since the number of lineage precursor cells was equivalent in the three groups of animals studied (Fig. 2). HQ exposure did not modify the number of polymorphonuclear leukocytes (PMN) in the early phase of maturation, but induced a significant decrease in the number of segmented cells at the last stage of maturation (Fig. 2). PHE exposure did not alter any phase of neutrophil maturation (Fig. 2).

\subsection{Leukocyte-endothelial interaction}

The behavior of leukocytes in the peripheral blood was evaluated by direct observation of the microcir300 307 302 303 
Anexo 7. Trabalho apresentado: MACEDO, S.M.; LOURENÇO, E.L.; BORELLI, P.; FOCK,

R.A.; FERREIRA, J.M. Jr; FARSKY, S.H.P. Effect of in vivo phenol or hydroquinone exposure on events related to neutrophil delivery during an inflammatory response. Toxicology, 2006.

+ Model

S.M.D. Macedo et al. / Toxicology $x x x(2006) x x x-x x x$
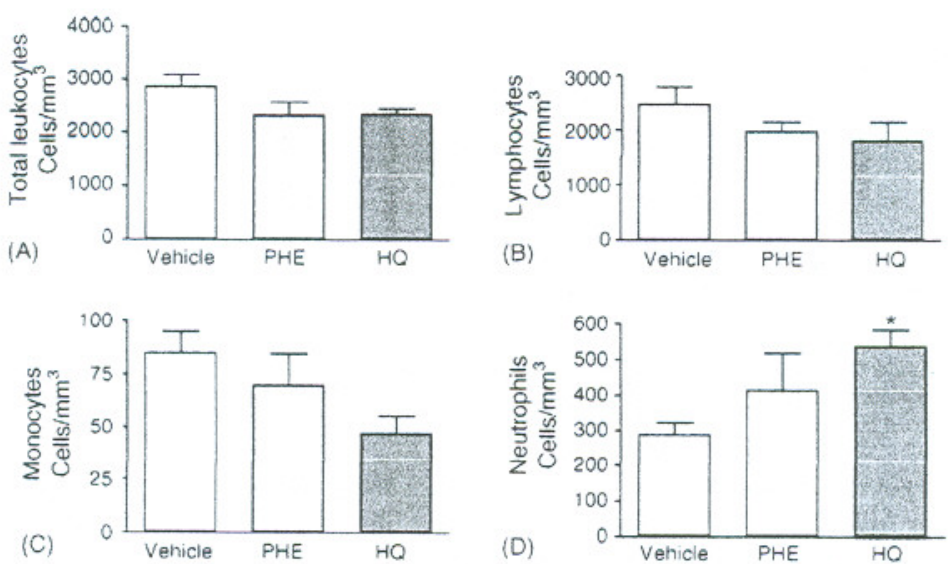

Fig. 1. Bar graphs demonstrate the number of circulating leukocytes in rats exposed to vehicle. PHE, or HQ $(50 \mathrm{mg} / \mathrm{kg}:$ i.p. route: 13 doses. daily on Days 1-5, 8-12 and 15-17). Blood samples were obtained from the abdominal aorta $24 \mathrm{~h}$ after the last dose of exposures and quantifications were carried out in Neubauer chambers and cytocentrifuge smears stained with May-Grünwald and Giemsa dye. Results express mean \pm S.E.M. of six animals in each group. ${ }^{*} P<0.05$ in comparison with the respective value in vehicle-exposed animals.

culatory network. As shown in Fig. $3 \mathrm{~A}$, HQ or PHE exposure increased initial contact between white cells and endothelial membranes, as shown by the increased number of rolling leukocytes in postcapillary venules of the mesentery. In HQ-exposed rats, this early interaction progressed to firm leukocyte attachment to the vessel wall, given that the number of cells adhered to the endothelium was also higher in this group of animals than in the PHE- or vehicle-exposed groups (Fig. 3B).

\subsection{Microvascular response to noradrenaline and} acetylcholine

At resting conditions, the diameters of arterioles and venules used for the assays were equivalent and varied between 20 and $30 \mu \mathrm{m}$. To investigate the vascular reactivity after chemical exposure, NA and Ach were topically applied to the microvascular network of the mesentery. Results presented in Fig. 4 show that chem-
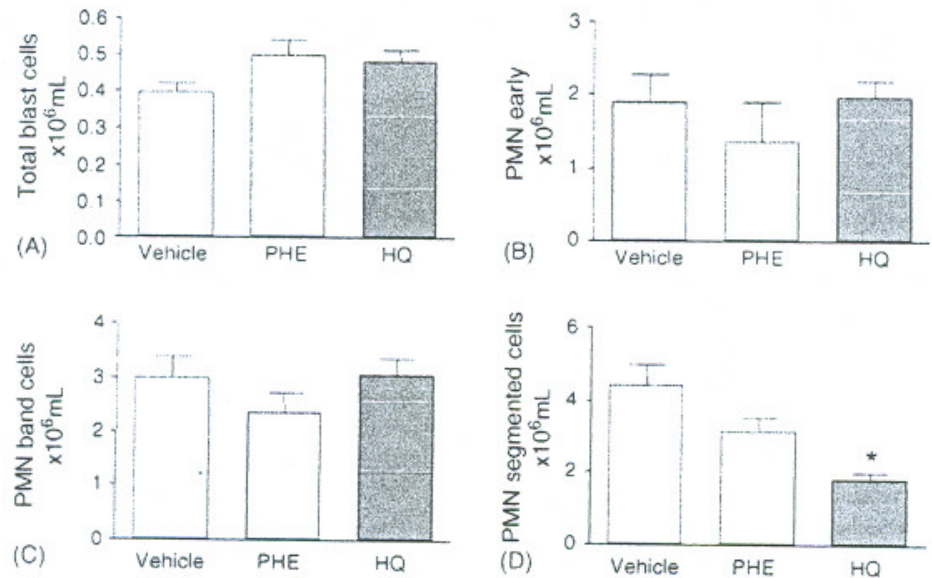

Fig. 2. Number of bone marrow leukocytes in rats exposed to vehicle, PHE or HQ ( $50 \mathrm{mg} / \mathrm{kg}$; i.p. route; 13 doses, daily on Days $1-5,8-12$ and 15-17). Cells were obtained $24 \mathrm{~h}$ after the last injection by flushing the femoral cavity with McCoy's $5 \mathrm{~A}$ medium with EDTA. The total number of cells was determined in Neubauer chambers and the differential number in cytocentrifuge smears stained with May-Grünwald and Giemsa dye. Results express mean \pm S.E.M. of six animals in each group. " $P<0.001$ in comparison with the respective value in vehicle-exposed animal 

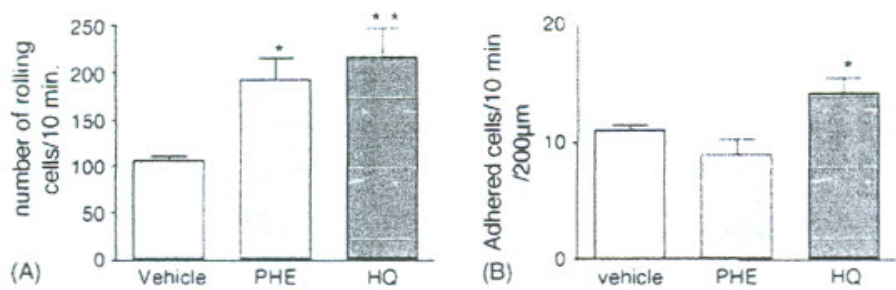

Fig. 3. Number of rolling (Panel A) and adhered leukocytes (Panel B) in postcapillary venules (20-30 $\mu \mathrm{m}$ diameter) of the mesentery of rats exposed to vehicle, PHE or HQ ( $50 \mathrm{mg} / \mathrm{kg}$; i.p. route: 13 doses, daily on Days 1-5, 8-12 and 15-17). Results were obtained by intravital microscopy $24 \mathrm{~h}$ after the last dose of exposures. Data express mean \pm S.E.M. of six animals in each group. ${ }^{\circ} P<0.01$ or ${ }^{*} P<0.001$ in comparison with the respective values in vehicle-exposed animals.

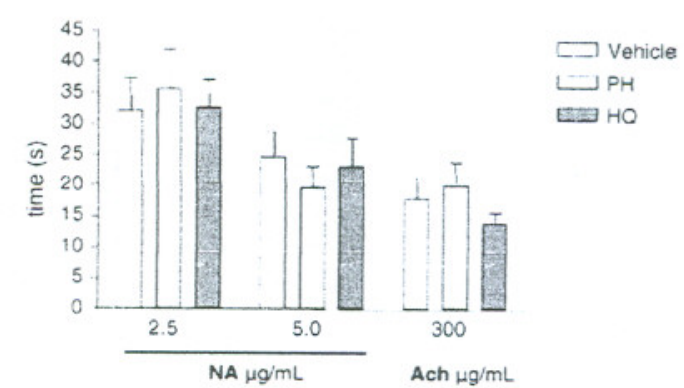

Fig. 4. Microvascular reactivity after topical application of noradrenaline (NA) and acetylcholine (Ach) in rats exposed to vehicle, PHE or HQ $(50 \mathrm{mg} / \mathrm{kg}$; i.p. route; 13 doses, daily on Days $1-5,8-12$ and 15-17). Results were obtained by intravital microscopy of the mesentery microcirculatory network, $24 \mathrm{~h}$ after the last dose of exposures. Data represent the time required for the cessation of blood flow in response to NA and its recovery after Ach. Data are expressed as mean \pm S.E.M. of six animals in each group. blood flow cytometry. Data presented in Fig. 6A show that the expression of L-selectin on PMN cells collected from PHE- or HQ-exposed rats was lower than that found in cells from control rats. After AMLP in vitro stimulation, cells obtained from HQ-exposed rats lost their ability to increase L-selectin expression on the membrane (Fig. $6 \mathrm{~A}$ ). On the other hand, the increment on L-selectin expression on PMNs collected from PHE-exposed rats after AMLP stimulation was equivalent to that found in cells from control rats (Fig. 6A). Expressions of $\mathrm{L}$-selectin on mononuclear cells (MN) were not altered by chemical exposures (data not shown).

Analysis of $\beta_{2}$ integrin expression on PMN cells showed that cells collected from PHE- or vehicleexposed rats presented a similar pattern of molecule expression even before or after fMLP stimulation (Fig. 6B). In contrast, PMN cells obtained from HQexposed animals presented elevated levels of $\beta_{2}$ integrin in both before or after in vitro stimulated conditions (Fig. 6B). As detected to L-selectin expression, the chem-

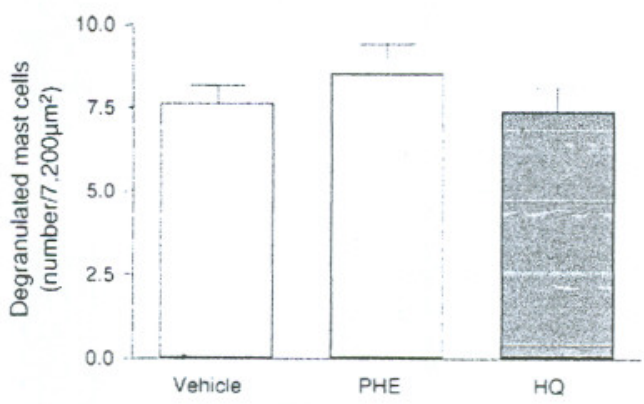

Fig. 5. Degranulated mast cell number in the mesentery of rats exposed to vehicle PHE or HQ ( $50 \mathrm{mg} / \mathrm{kg}$; i.p. route; 13 doses, daily on Days $1-5,8-12$ and 15-17). Results were obtained by intravital microscopy, $24 \mathrm{~h}$ after the last injection and $10 \mathrm{~min}$ after topical application of $48 / 80$ compound. Data are expressed as mean \pm S.E.M. of six animals in each group. 

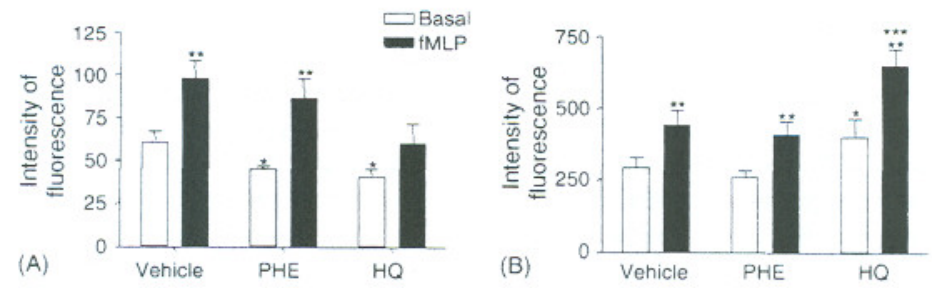

Fig. 6. Leukocyte adhesion molecule expression on peripheral PMN cells obtained from vehicle-, PHE- or HQ-exposed rats ( $50 \mathrm{mg} / \mathrm{kg}$ : i.p. route: 13 doses, daily on Days 1-5, 8-12 and 15-17). Leukocytes were obtained from blood samples collected from the abdominal aorta. L-Selectin (Panel A) or $\beta_{2}$ integrin (Panel B) expression was quantified in quiescent (basal condition) neutrophils or after fMLP stimulation (10 $0^{-8} \mathrm{M}$ ) by blood flow cytometry. Results are expressed as mean \pm S.E.M. of samples collected from four animals in each group. Assays were performed in duplicate. ${ }^{*} P<0.01$ vs. basal values from vehicle-exposed rats, ${ }^{*} P<0.05$ vs. respective basal values and ${ }^{\cdots} P<0.05$ vs. values on MLP stimulated cell from vehicle- or PHE-exposed rats.
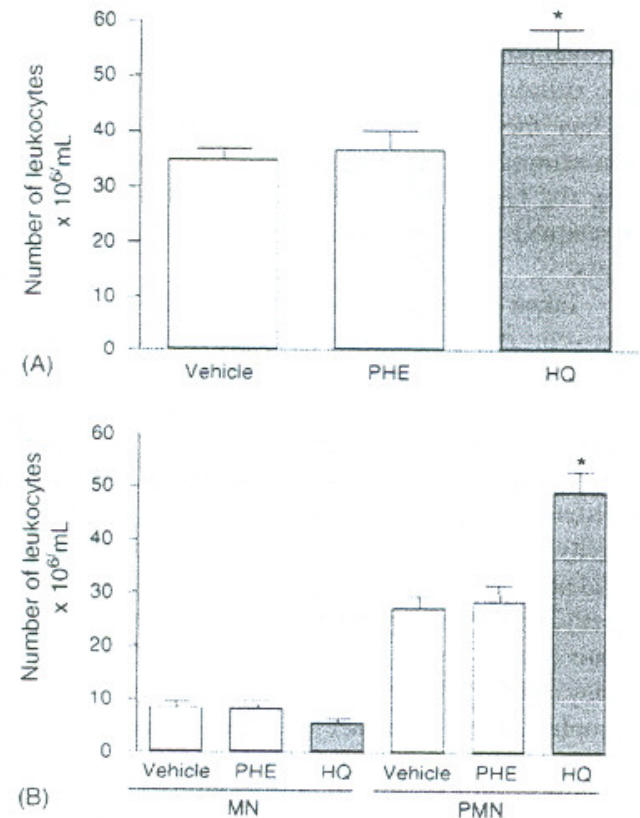

Fig. 7. Number of total (Panel A) or differential (B) leukocytes in inflammatory exudates of rats exposed to vehicle, PHE, or HQ $150 \mathrm{mg} / \mathrm{kg}$; i.p. route; 13 doses, daily on Days $1-5,8-12$ and $15-17)$. Inflammation was induced in the subcutaneous cavity $24 \mathrm{~h}$ after the last dose of exposures (oyster glycogen: $1 \mathrm{~mL} 5 \%$ solution). Exudates were collected $6 \mathrm{~h}$ later. Total leukocytes were quantified in a Neubauer chamber and differential cells in cytocentrifuge smears stained with May-Grünwald and Giemsa dye. Results are expressed as mean \pm S.E.M. of six animals in each group. $\mathrm{MN}$, mononuclear cells; $\mathrm{PMN}$, polymorphonuclear cells. ${ }^{\circ} P<0.001$ in comparison with the respective values in vehicle-exposed animals. ical exposures did not modify the $\beta_{2}$ integrin expression on $\mathrm{MN}$ cells (data not shown).

\subsection{Local leukocyte recruitment during an inflammatory response}

The leukocyte influx into inflamed subcutaneous tissue was quantified $6 \mathrm{~h}$ after the injection of oyster glycogen into the air pouch. As shown in Fig. 7A, leukocyte migration into the site of lesion in PHE-exposed rats was equivalent to the migration to the inflamed cavity in control animals. However, the total number of leukocytes present in the inflamed pouch of HQ-exposed rats was higher than that found in PHE- or vehicle-exposed rats (Fig. 7A). Differential analysis demonstrated that the higher numbers of leukocytes in inflammatory exudates of HQ-exposed rats represented a significant increase in the number of neutrophils accumulated in the pouch (Fig. 7B).

\section{Discussion}

Neutrophils are among the first leukocytes recruited from reservoir compartments into an injured area, and their interaction with different cells during the migration process triggers intracellular events whose steps advance the inflammatory response. Alterations in this complex process of delivery may reduce or increase the accumulation of white cells at the site of lesion; in both cases, the host defense is impaired. In the current study we proposed an experimental protocol involving intoxication with $\mathrm{PHE}$ or $\mathrm{HQ}$ to investigate their role on mechanisms responsible for neutrophil mobilization, as well as their effect during an acute inflammatory response

Our data showed that HQ exposure induced neutrophilia, probably because of a more intense mobilization of segmented cells from the bone marrow comnart- 
ment. While it has been previously suggested that HQ impairs production and/or maturation of granulocytes (Sinder. 2002 2. 2004), our data show that HQ does not affect precursor cell numbers, but induces earlier maturation of neutrophils. In HQ-exposed rats we detected a significant reduction in the number of PMN cells at the last phase of maturation in the bone marrow compartment and increased neutrophil numbers at the peripheral compartment. In contrast, PHE exposure did not alter any phase of cell maturation in the bone marrow compartment and did not modify the circulating number of leukocytes. These effects might be expected since PHE seems to act synergistically with HQ or other phenolic compounds on granulocytic lineage alterations (Kolachana 4 al. 1993 Woran at al. 1996. Henchter et al. 1996).

In the circulation, leukocytes move in the mainstream of blood. However, during activation states, white cells interact with the microcirculatory vessel wall for subsequent migration into the site of injury. Modifications . 5 in microvascular wall reactivity and in the activation of .6. leukocytes and the endothelium - both effects mediated $\therefore$ by endogenous substances secreted at the site of injury A. promote leukocyte-endothelial interactions. Data herein 4.9 suggest that HQ and PHE exposure induced rolling of 420 leukocytes to postcapillary venules of the mesentery. 42. However, only leukocytes from HQ-exposed rats were 22 able to advance and adhere to the vessel wall.

It has been reported that HQ is a potent constric24 tor of small arterioles, mainly by blocking microvessel dilation dependent on nitric oxide (NO) (Lubbe et al.. J49.4; Zhao and loshua, 1908). It is well-known that NO production is increased in response to Ach, and that NO diffuses from endothelial cells into the cytosol of adjacent vascular smooth muscle cells to activate the enzyme guanylyl cyclase, increasing GMPc levels, which result in vascular smooth cell relaxation (R usso ef 4. $2(022)$. Thus, the possibility that the enhancement of leukocyte-endothelial interactions detected in rats exposed to phenolic compounds could result from modifications in the microvascular reactivity was investigated 36 by measurements of arteriolar constriction and its subse17 quent dilation after topical application of NA and Ach on $4 \rightarrow$ the mesenteric tissue, respectively. Our data showed that . 34 the times required for pharmacological responses were 40) similar in all groups of animals studied, suggesting that ${ }_{44}$. the leukocyte-endothelial interactions are not dependent ${ }_{\triangle 4}$ on changes in microvascular reactivity. Additionally, the ${ }_{443}$ mesenteric tissue has postcapillary venules surrounding ${ }_{44}$ mast cells, which secrete mediators that clearly induce ${ }_{445}$ in vivo rolling behavior, such as histamine (Kubes and

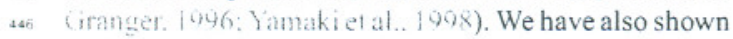
${ }_{447}$ that local injections of phenolic compounds for a long period of time did not alter the numbers of mesentery mast cells or their ability to degranulate in response to compound $48 / 80$, suggesting that the elevated number of rolling leukocytes in the postcapillary venules of animals exposed to phenolic compounds does not involve substances secreted from an elevated mast cell activity.

The expression of adhesion molecules on both leukocytes and the endothelium mediates leukocyte-endothelial interactions and also indicates the stage of cellular activation (Ley. 2002; thrhardi el at. 20014). Neutrophils rapidly express L-selectin and subsequently upregulate $\beta_{2}$ integrin under stimulation with chemotactic factors. This pattern of adhesion molecule expression during leukocyte priming in several inflammatory diseases has been fully demonstrated (Fernander-Segina ef al. 1006) Walchech et a1. 1946: Willams and Solomkin. foy9: Kana and Knath. 2(h)!: Noguera et at. 206i- Camm ef af. sotis). Our data suggest that HQ exposure induces neutrophil activation, as indicated by a downregulation of L-selectin and an upregulation of $\beta_{2}$ integrin expression, which may lead to cellular activities during an inflammatory process. Then, the importance of adhesion molecule expression in neutrophils from HQ-exposed rats was demonstrated by the higher influx of neutrophils into subcutaneous inflamed areas compared to PHE- or vehicle-exposed rats.

Taken together, our data support the notion that the benzene metabolite quinone plays a role in the toxicity of granulocytes and influences the host defense against nonspecific agents. This is the first report of neutrophil activation by $\mathrm{HQ}$ in vivo, resulting in an excessive inflammatory response. Additionally, our data demonstrate the differential role of phenolic compounds in cellular reactivity, since unlike exposure to $\mathrm{HQ}$, PHE administration did not promote alterations on neutrophil maturation and activation. Although PHE is endogenously transformed into $\mathrm{HQ}$, endogenous transformation of PHE into $\mathrm{HQ}$ may not be sufficient to generate the same level of neutrophil priming as direct HQ exposure. It is important to emphasize that rats are able to metabolize benzene, and that they have been used as a model for human exposure because of close similarities in the biotransformation of

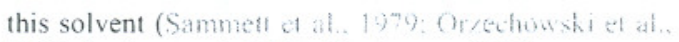
1905: Seatom et al. 1995; Hetiderson. 1496).

\section{Acknowledgments}

We gratefully acknowledge Suéllen Cristine Moreira Vaz, Amanda R. Crisma and Karina Nakajima for technical assistance and FAPESP for financial support (grants $\# 03 / 04013-8$ ). S.H.P. Farsky is fellow of the Conselno 
Nacional de Pesquisa e Tecnologia (CNPq) and S.M.D. Macedo and R.A. Fock are graduate fellows.

\section{References}

Bochner, B.S., 2004. Adhesion molecules as therapeutic targets. Immunol. Allergy Clin. North Am. 24 (4), 615-630.

Caimi, G., Montana, M., Carollo, C., Porretto, F., Vaccaro, F., Canino, B., Lo Presti, R., 2005. Polymorphonuclear leukocyte integrins in chronic renal failure. Clin. Hemorheol. Microcirc. 32 (1), 43-49.

Cambi, A., Figdor, C.G., 2003. Dual function of C-type lectin-like receptors in the immune system. Curr. Opin. Cell Biol. 15 (5), 539-546.

Cheynier, V., 2005. Polyphenols in foods are more complex than often thought. Am. J. Clin. Nutr. 81 (Suppl.), 223S-229S.

Dahlen, S.E., Bjork, J., Hedquist, P., Arfors, K.E., Hammarstrom, S., Lindgren, J.A., Samuelsson, B., 1981. Leukotrienes promote plasma leakage and leukocyte adhesion in postcapillary venules: in vivo effects with relevance to the acute inflammatory response. Proc. Natl. Acad. Sci. 78 (6), 3887-3891.

Doepker, C.L., Dumont, K.W., O'Donoghue, J., English, J.C., 2000. Lack of induction of micronuclei in human peripheral blood lymphocytes treated with hydroquinone. Mutagenesis 15 (6), 479-487.

Duarte-Davidson, R., Courage, C., Rushton, L., Levy, L., 2001. Benzene in the environment: an assessment of potencial risks to the health of the population. Occup. Environ. Med. 58, 2-13.

Edwards, J.C., Sedwick, A.D., Willoughby, D.A., 1981. The formation of a structure with the features of synovial lining by subcutaneous injection of air: an in vivo tissue culture system. J. Pathol. 134 (2), $147-156$.

Ebnet, K., Vestweber, D., 1999. Molecular mechanisms that control leukocyte extravasation: the selectins and the chemokines. Histochem. Cell Biol. 112 (1), 1-23.

Ehrhardt, C., Kneuer, C., Bakowsky, U., 2004. Selectins-an emerging target for drug delivery. Adv. Drug Deliv. Rev. 56, 527-549.

Farsky, S.H.P., Borelli, P., Fock, R.A., Proto, S.Z., Ferreira Jr, J.M., Mello, S.B., 2004. Chronic blockade of nitric oxide biosynthesis in rats: effect on leukocyte endothelial interaction and on leukocyte recruitment. Inflamm. Res. 53 (9), 442-452

Farsky, S.H.P., Sannomiya, P., Garcia-Leme, J., 1995. Secreted glucocorticoids regulate leukocyte-endothelial interactions in inflammation. A direct vital microscopic study. J. Leukoc. Biol. 57 (3), 379-386.

ernandez-Segura, E., Garcia, J.M., Campos, A., 1996. Topographic distribution of CD18 integrin on human neutrophils as related to shape changes and movement induced by chemotactic peptide and phorbol esters. Cell Immunol. 171 (1), 120-125.

Fortes, Z.B., Farsky, S.P., Oliveira, M.A., Garcia-Leme, J., 1991. Direct vital microscopic study of defective leukocyte-endothelial interaction in diabetes mellitus. Diabetes $40(10), 1267-1273$.

Goldstein, B.D., Snyder, C.A., Laskin, S., Bromberg, 1., Albert, R.E. Nelson, N., 1982. Myelogenous leukemia in rodents inhaling benzene. Toxicol. Lett. 13 (3-4), 169-173.

Granger, D.N., Kubes, P., 1994. The microcirculation and inflammation: modulation of leukocyte-endothelial cell adhesion. J. Leukoc. Biol. $55(5), 662-675$.

Hazel, B.A., Kalf, G.F., 1996. Induction of granulocytic differentiation in myeloblast by hydroquinone, a metabolite of benzene, involves the leukotriene D4 receptor. Recept. Signal Transduct. 6 (1), 1-12.

Hazel, B.A., O'Connor, A., Niculescu, R., Kalf, G.F., 1996a. Induction of granulocytic differentiation in a mouse model by ben. zene and hydroquinone. Environ. Health Perspect. 104 (Suppl. 6), $1257-1264$.

Hazel, B.A., Baum, C., Kalf, G.F., 1996b. Hydroquinone, a bioreactive metabolite of benzene, inhibits apoptosis in myeloblast. Stem Cells 14 (6), 730-742.

Henderson, R.F., 1996. Species differences in the metabolism of benzene. Environ. Health Perspect. 104 (Suppl. 6), 1173-1175.

Henschler, R., Glatt, H.R., Heyworth, C.M., 1996. Hydroquinone stimulates granulocyte-macrophage progenitor cells in vitro and in vivo. Environ. Health Perspect. 104 (Suppl. 6), 1271-1274.

Hogg, N., Henderson, R., Leitinger, B., McDowall, A., Porter, J., Stanley, P., 2002. Mechanisms contributing to the activity of integrins on leukocytes. Immunol. Rev. 186, 164-171.

Hubbard, A.K., Rothlein, R., 2000. Intercellular adhesion molecule$1($ ICAM-1) expression and cell signaling cascades. Free Radic. Biol. Med. 28 (9), 1379-1386.

Kaba, N.K., Knauf, P.A., 2001. Hypotonicity induces L-selectin shedding in human neutrophils. Am. J. Physiol. Cell Physiol. 281 (4), 1403-1407.

KalfF G.F., 2000. Utility of a mouse model for studying the effects of benzene on the myeloid lineage: effects of hydroquinone on a model myeloid system. J. Toxicol. Environ. Health A 61 (5-6), 399-411.

Kim, M., Carman, C.V., Yang, W., Salas, A., Springer, T.A., 2004. The primacy of affinity over clustering in regulation of adhesiveness of the integrin \{alpha\} L \{beta\}2. J. Cell Biol. 167 (6), 1241-1253.

Kluger, M.S., 2004. Vascular endothelial cell adhesion and signaling during leukocyte recruitment. Adv. Dermatol. 20, 163-201.

Kolachana, P., Subrahmanyam, V.V., Meyer, K.B., Zhang, L., Smith. M.T., 1993. Benzene and its phenolic metabolites produce oxidative DNA damage in HL60 cells in vitro and in the bone marrow in vivo. Cancer Res. 53, 1023-1026.

Kubes, P., Granger, D.N.. 1996. Leukocyte-endothelial cell interactions evoked by mast cells. Cardiovasc. Res. 32, 699-708.

Kuldo, J.M., Ogawara, K.1., Werner, N., Asgeirsdottir, S.A., Kamps. J.A., Kok, R.J., Molema, G., 2005. Molecular pathways of endothe lial cell activation for (targeted) pharmacological intervention of chronic inflammatory diseases. Curr. Vasc. Pharmacol. 3 (1), $11-39$

Ley, K., 2002. Integration of inflammatory signals by rolling neutrophil. Immunol. Rev. 186 (1), 8-18.

Li, Y., Kuppusamy, P., Zweir, J.L., Trush, M.A., 1996. Role of Cu/Znsuperoxide dismutase in xenobiotic activation. II. Biological effects resulting from the $\mathrm{C} u / \mathrm{Zn}$-superoxide dismutase-accelerated oxidation of the benzene metabolite 1,4-hydroquinone. Mol. Pharmacol. 49 (3), $412-421$

Lubbe, A.S., Garrison, R.N., Harris, P.D., 1994. Endotheliumdependent microvascular responses to activated complement. J. Surg. Res. 57 (6), 654-660.

McCue, J.M., Lazis, S., John Cohen, J., Modiano, J.F., Freed, B.M. 2003. Hydroquinone and catechol interfere with T-cell cycle entry and progression through the Gl phase. Mol. Immunol. 39 (16). 995-1001.

Moran, J.L., Siegel, D., Sun, X.M., Ross, D., 1996. Induction of apoptosis by benzene metabolites in HL60 and CD 34+ human bone marrow progenitor cells. Mol. Pharmacol. 50 (3), 610-615.

Noguera, A., Sala, E., Pons, A.R., lglesias, J., MacNee, W., Agusti, A.G., 2004. Expression of adhesion molecules during apoptosis of circulating neutrophils in COPD. Chest 125 (5), 1837-1842.

Nourshargh, S., Marelli-Berg, F.M., 2005. Transmigration through venular walls: a key regulator of leukocyte phenotype and function. Trends lmmunol. 26 (3). 157-165. 
Ong, C.N., Lee, B.L., Shi, C.Y., Ong, H.Y., Lee, H.P., 1994. Elevated levels of benzene-related combounds in the urine of cigarette smokers. int. J. Cancer 59, 177-180.

Orzechowski, A., Schwarz, L.R., Schwegler, U., Bock, K.W., Snyder. R., Schrenk, D., 1995. Benzene metabolism in rodent hepatocytes: role of sulphate conjugation. Xenobiotica 25 (10), $1093-$ 1102.

Poirier. M., Fourneir, M., Brousseau, P., Morin, A., 2002. Effects of volatile aromatics, aldehydes, and phenols in tobacco smoke on viability and proliferation of mouse lymphocytes. J. Toxicol. Env. iron. Health A 65 (19), 1437-1451.

Pyatt, D.W., Stillman, W.S., Irons, R.D., 1998. Hydroquinone, a reactive metabolite of benzene, inhibits NF-kappa B in primary human CD4+ T lymphocytes. Toxicol. Appl. Pharmacol. 149 (2). $178-184$.

Pyatt. D.W., Yang, Y., Stillman, W.S., Cano, L.L., Irons, R.D., 2000. Hydroquinone inhibits PMA-induced activation of NFkappaB in primary human $\mathrm{CD} 19+\mathrm{B}$ lymphocytes. Cell Biol. Toxicol. 16(1), $4 !-5 !$.

Rosen, S.D., 2004. Ligands for L-selectin: homing, inflammation, and beyond. Annu. Rev. Immunol. 22 (1), 29-56.

Russo, G., Leopold, J.A., Loscalzo, J., 2002. Vasoactive substances: nitric oxide and endothelial dysfunctions in atherosclerosis. Vasc. Pharmacol. 38, 259-269.

Salazar-Mather, T.P., Hokeness, K.L., 2003. Calling in the troops: regulation of inflammatory cell trafficking through innate cytokine/chemokine networks. Viral Immunol. 16 (3), 291-306.

Sallusto, F.. Mackay, C.R., 2004. Chemoattractants and their receptors in homeostasis and inflammation. Curr. Opin. Immunol. 16 (6). 724-731.

Sammett. D., Lee, E.W., Kocsis, J.J., Snyder, R., 1979. Partial hepatectomy reduces both metabolism and toxicity of benzene. J. Toxicol. Environ. Health 5 (5), 785-792.

Schlosser, M.J., Kalf, G.F., 1989. Metabolic activation of hydroquinone by macrophage peroxidase. Chem. Biol. Interact. 72(1-2). 191-207.

Schlosser, M.J., Shumira, R.D., Kalf, G.F., 1990. Prostaglandin H synthase catalyzed oxidation of hydroquinone to a sulfhydrylbinding and DNA-damaging metabolite. Chem. Res. Toxicol. 3 (4). 333-339.

Schrenk, D., Orzechowski, A., Schwarz, L.R., Snyder, R., Burchell, B. Ingelman-Sundberg, M., Bock, K.W., 1996. Phase II metabolism of benzene. Environ. Health Perspect. 104 (Suppl. 6), 11831188.

Seaton. M.J., Schlosser, P., Medinsky, M.A., 1995. In vitro conjugation of benzene metabolites by human liver: potential influence of interindividual variability on benzene toxicity, Carcinogenesis is (7). 1519-1527.

Smith, M.T., Zhang, L., Jeng, M. Wang, Y., Guo, W., Duramad, P., Hubbard, A.E., Hofstadler, G., Holland, N.T., 2000. Hydroquinone, a benzene metabolite, increases the level of aneusomy of Chromo. somes 7 and 8 in human CD34-positive blood progenitor cells. Carcinogenesis 21 (8), 1485-1490.

Snyder, R., 2000. Overview of the toxicology of benzene. J. Toxicol. Environ. Health A $6 !$ (5-6), 339-346.

Snyder. R., 2002. Benzene and Leukemia. Crit. Rev. Toxicol. 32 (3). 155-210.

Snyder, R., 2004. Xenobiotic metabolism and the mechamism(s) of benzene toxicity. Drug Metab. Rev. 36 (3-4), 531-547.

Steeber, D.A., Tedder, T.F., 2000. Adhesion molecule cascades direct lymphocyte recirculation and leukocyte migration during inflammation. Immunol. Res, 22 (2-3), 299-317.

Steeber, D.A., Venturini, G.M., Tedder, T.F., 2005. A new twist to the leukocyte adhesion cascade: intimate cooperation is key. Trends Immunol. 26 (1), 9-12.

Stillman, W.S., Varella-Garcia, M., Irons, R.D., 2000. The benzene metabolite, hydroquinone, selectively induces $5 q 31-$ and -7 in human CD34+CD19- bone marrow cells. Exp. Hematol. 28 (2), 169-176.

Venturi, G.M., Tu, L., Kadono, T., Khan, A.1., Fujimoto, Y., Oshel, P. Bock, C.B., Miller, A.S., Albrecht, R.M., Kubes, P., Steeber, D.A. Tedder, T.F., 2003. Leukocyte migration is regulated by L-selectin endoproteolytic release. Immunity 19 (5), 713-724.

Walcheck, B., Kahn, J., Fisher, J.M., Wang, B.B., Fisk, R.S., Payan. D.G.. Feehan, C., Betageri, R., Darlak, K.. Spatola, A.F., Kishimoto, T.K., 1996. Neutrophil rolling altered by inhibition of L. selectin shedding in vitro. Nature 380 (6576), 720-723.

Wang, Q., Doerschuk, C.M., 2002. The signaling pathways induced by neutrophil-endothelial cell adhesion. Antioxid. Redox Signal. 4 (1), 39-47.

Wiemels, J., Smith, M.T., 1999. Enhancement of myeloid cell growt by benzene metabolites via the production of active oxygen species. Free Radic. Res. 30 (2), 93-103.

Williams, M.A.. Solomkin, J.S., 1999. Integrin-mediated signaling in human neutrophil functioning. J. Leukoc. Biol. 65 (6), 725-736.

Yamaki, K., Thorlacius, H., Xie, X., Lindbom, L., Hedqvist, P., Raud, J., 1998. Characteristics of histamine-induced leukocyte rolling in the undisturbed microcirculation of the rat mesentery. Br. J. Pharmacol. 123, 309-9.

Zhao, H., Joshua, I.G., 1998. Release of endogenous nitric oxide mediates arteriolar dilation to endothelin in rat striated muscle. J. Cardiovasc. Pharmacol. 31 (3), 331-335. 
IN VIVO HYDROQUINONE EXPOSURE INHIBITS LEUKOCYTE MIGRATION DURING AN ALLERGIC LUNG INFLAMMATION IN RATS

S.M.D. Macedo ${ }^{a, b}$; S.C.M. Vaz ${ }^{a}$; E.L.B. Lourenço ${ }^{a, c}$; M. da Glória de Souza ${ }^{a}$; G. Cavriani ${ }^{\text {d; }}$ A.P. Ligeiro-Oliveira ${ }^{\text {d; S.R. Almeida }}{ }^{a}$; W. Tavares de Lima ${ }^{\text {; }}$; S.H.P. Farsky ${ }^{\mathrm{a}^{*}}$

${ }^{a}$ Department of Clinical and Toxicological Analysis, School of Pharmaceutical Sciences, University of São Paulo, São Paulo, Brazil; ${ }^{b}$ Department of Heatlh Science, Regional Integrated University of Alto Uruguai and Missões, Erechim, Brazil, 'Paranaense University, Umuarama, Brazil; 'Department of Pharmacology, Institute of Biomedical Science, University of São Paulo, São Paulo, Brazil.

"Corresponding author: S.H.P. Farsky

Av. Prof. Lineu Prestes, 580 Bl 13 B, São Paulo, 05508-900, Brasil;

FAX: 55-11-3815-6593

Telephone: 55-11-3091-2197

sfarsky@usp.br 


\section{Abstract}

We investigated the effects of hydroquinone $(\mathrm{HQ})$ exposure on the host defense during a lung allergic inflammatory response. Male Wistar rats were intraperitoneally exposed to vehicle or $\mathrm{HQ}$ once a day, for 22 days with a twoday interval every five days. On day 10, the animals were intraperitoneally sensitized with ovalbumin (OVA). Thirteen days after sensitization and 24 hours after the last injection of $\mathrm{HQ}$ or vehicle, rats were challenged with OVA by inhalation. The numbers of leukocytes in the bronchoalveolar fluid were reduced in HQ-exposed rats. However, numbers of polymorphonuclear cells in the pulmonary tissue were equivalent in $\mathrm{HQ}$ or vehicle-exposed rats, as measured by myeloperoxidase activity. The inability of leukocyte migration into inflamed tissue was not influenced by changes in the number of circulating leukocytes or the expression of adhesion molecules on circulating leukocytes or pulmonary endothelium. Nevertheless, the effect is dependent on impairment on IgEmediated mast cell degranulation, since tracheal contraction in vitro in response to OVA was reduced in tissues obtained from $\mathrm{HQ}$-exposed rats, and the capacity to mount passive cutaneous anaphylaxis was impaired in normal rats previously sensitized with serum from $\mathrm{HQ}$-exposed rats. Equivalent proliferation of spleen lymphocytes in response to OVA or Concanavalin A in cells collected from vehicle- or HQ- exposed rats excluded possible alterations on antigen recognize and on intracellular signaling of proliferation. Together, our data show that $\mathrm{HQ}$ exposure diminishes leukocyte recruitment during a host allergic response, primary depending on inhibition of lgE-mediated mast cell degranulation.

Keywords: hydroquinone, leukocyte migration, pulmonary allergic inflammation, ovalbumin, mast cell degranulation, IgE. 


\section{Introduction}

Asthma is an inflammatory disease of the lungs characterized by local mast cell activation, influx of leukocytes and reversible episodes of bronchospasm (Lazaar and Panettieri, 2005). Briefly, the early phase of asthma is characterized by airway smooth muscle contraction, mucus secretion and increase of microvascular permeability caused by mast cell-derived mediators (Pascual and Peters, 2005; Lazaar and Panettieri, 2005), which in turn leads to cellular influx and airway epithelial injury and bronchial hyper responsiveness (Pascual and Peters, 2005). All of these hallmarks of asthma are dependent on the synthesis of immunoglobulin $\mathrm{E}(\mathrm{IgE})$ antibodies and their fixation on highaffinity surface receptors ( $\mathrm{Fc \varepsilon} \mathrm{RI}$ ) of mast cells in sensitized subjects (Miyasaka et al., 1999; Bochner et al., 2004). The first step in this process is the antigen presentation by professional antigen-presenting cells (APC) to B lymphocytes, and the subsequent enhancement of immunoglobulin $\mathrm{E}$ ( $\mathrm{IgE})$ antibody production. During a challenge, Th2 helper T cells are activated and proliferate by action of Interleukins-4 (IL-4), 5 (IL-5) and 13 (IL13). Subsequently, these activated $T$ cells secrete cytokines, such as IL-4 and IL-13, which drive Blymphocytes to produce specific antibodies (Murphy and Reiner, 2002; Careau et al., 2002; Ansel et al., 2003).

In terms of cellular traffic, the mechanisms underlying involve tethering, rolling and adherence of leukocytes to the endothelium of the lung microvasculature under influence of chemical mediators secreted by different resident cells, including mast cells, fibroblasts and macrophages (Kubes and Kerfoot, 2001; Bochner, 2004). The initial contact of rolling leukocytes with the endothelium is mediated by expressions of L-selectin and integrins (very late antigen-4 (VLA-4) and $\alpha \mathrm{d} \beta 2$ ) on leukocytes, which bind to specific carbohydrate ligands and to vascular cell-adhesion molecule 1 (VCAM-1) on the endothelium, respectively (Grayson et al., 1999; Kikuchi et al., 2003). As the response progresses, this initial binding is followed by the induction of firm adhesion, mediated primarily by the expression of $\beta 1$ (CD19) and $\beta 2$ (CD18) integrins on 
respectively (Grayson et al., 1999; Kikuchi et al., 2003). As the response progresses, this initial binding is followed by the induction of firm adhesion, mediated primarily by the expression of $\beta 1$ (CD19) and $\beta 2$ (CD18) integrins on leukocyte membranes and their interaction with intercellular adhesion molecule 1 (ICAM-1) and VCAM-1 (von Andrian and Mackay, 2000; Tachimoto et al., 2002). Subsequently, leukocytes undergo diapedesis into the tissue by expression of ICAM-1, platelet-endothelial cell-adhesion molecule 1 (PECAM-1) and migrate at the extravascular tissue by expression of $\beta 1$ and $\beta 7$ integrins (Vaporciyan et al., 1993; Miller et al., 2001).

Various experimental models of asthma have been developed for studying the inflammatory mechanisms of the airways (Bice et al, 2000). Challenged rats previously sensitized to an antigen associated to the adequate adjuvant, induces the secretion of the complex network of chemical mediators, migration and activation of leukocytes and resident cells, which are responsible for the beginning and improvement of the process (Tavares de Lima and Silva, 1998; Kim et al., 2004; Leung et al., 2004). In a IgE-mediated response, mast cells degranulation trigger the process (Tavares de Lima and Silva, 1998; Guo et al., 2001).

Benzene, an organic compound with well-known immunotoxic properties, is widely used as an industrial solvent. It is a component of cigarette smoke and a common environmental pollutant generated by the processing, combustion and evaporation of gasoline. The immunosuppressive effects of benzene have been associated to its phenolic bio-products (Hoffmann et al., 1983; Li et al., 1996; 1997; McCue et al., 2000; Snyder, 2002,2004).

Hydroquinone $(H Q)$ is a reactive metabolite from benzene biotransformation that can cause serious solvent intoxication (Schrenk et al., 1996; Snyder, 2000; 2002; 2004). It is produced via oxidation reactions catalized by liver cytochrome P450 enzymes (Goldstein et al., 1982; Snyder 2002; 2004). The ability of circulating $H Q$ to easily penetrate into the bone marrow compartment, to be locally metabolized and to accumulate there contributes in an important way to the myelotoxicity in benzene intoxication 
(Schlosser and Kalf, 1989; Schlosser et al., 1990). The complex immunossupressive effects of $\mathrm{HQ}$ and its quinone derivatives have been demonstrated and their underlying mechanisms are likely associated with higher concentrations of $\mathrm{HQ}$ in different body compartments, which affect cell maturation and function.

In vitro assays have demonstrated that $\mathrm{HQ}$ has potential immunosuppressive effects on lymphocytes, mainly blocking their production and their ability of proliferation (Li et al., 1996; 1997; Pyatt et al., 1998; 2000; McCue et al., 2003). Regarding to granulocyte lineage, in vivo and in vitro exposures have shown that $\mathrm{HQ}$ promotes alterations on phases of neutrophil maturation at the bone marrow cavity, with consequent neutrophilia (Kolachana et al., 1993; Henschler et al., 1996; De Caprio, 1999; Macedo et al., 2006).

Despite the broad actions of $\mathrm{HQ}$ on white cells, the role of this phenolic compound on leukocyte recruitment during an allergic response in vivo has not been show. Using ovalbumin (OVA)-sensitized rats as an experimental model, we herein demonstrated for the first time that $H Q$ exposure for an extended period of time inhibits leukocyte infiltration into the lung during an allergic inflammatory response. The mechanisms involved are not related to leukocyte production, expression of adhesion molecules involved in leukocyte recruitment neither or ability of lymphocyte proliferation. However, we verified that inhibition on immunoglobulin synthesis is an important mechanism responsible for the subsequent impaired mast cell degranulation and development of the response. 


\section{Materials and methods}

\subsection{Chemicals}

Pentobarbital sodium (Cristália, Brazil); Chloral hydrate (Rhodia-Farma, Brazil); Ketamine (Vetaset $\Theta$, Lab. Font Dodte, USA); Xylazine (Vensol, Lab. Konie); FITC-labeled anti-rat CD62L (L-selectin, LECAM-1), FITC-labeled antirat CD18 ( 32 integrin), R-PE-labeled anti-rat CD31 (PECAM-1), R-PE-labeled anti-rat CD106 (VCAM-1) were purchased from BD Pharmingen; FITC-labeled anti-rat CD54 (ICAM-1), (Southern Biotechnology Associates); Heparin (Liquemine ${ }^{\circledR}$, Roche); Ovalbumin (chicken egg albumin crude, grade II), Concanavalin A from Canavalia ensiformis (type IV), RPMI 1640 medium, $\theta$ dianisidine, Hexadecyltrimethyl ammonium bromide, EDTA and Hydroquinone compound were purchased from Sigma (St. Louis, MO, USA); O.C.T. Tissue Tek ${ }^{\mathrm{TM}}$ mounting medium (Raymond A Lamb, London, UK); Block solution (Pierce CO., Rockford, Illinois); $\mathrm{H}_{2} \mathrm{O}_{2}$ and Ethanol (Merck, USA); [ $\left.{ }^{3} \mathrm{H}\right]$ thymidine (Amershan Pharmacia Biotech UK Limited, UK); Fetal calf serum (Gibco-BRL, MD,USA).

\subsection{Rats}

Adult male Wistar rats weighing $180-220 \mathrm{~g}$ were employed. Animals were kept under light/dark cycle (12 h on, $12 \mathrm{~h}$ off), allowed a standard pellet diet and water ad libitum. All animal procedures were performed according to approved protocols and in accordance with recommendations for the proper use and care of laboratory animals.

\subsection{Protocol of exposure}

$\mathrm{HQ}(50 \mathrm{mg} / \mathrm{Kg}$ in a final volume of $1 \mathrm{~mL})$ was intraperitoneally injected, once a day. Animals used as control received the same volume of vehicle by 
the same route. $\mathrm{HQ}$ was dissolved in absolute ethanol ( $5 \%$ of the final solution) and the volume was completed with sterile saline solution. The animals received 16 daily doses of treatments, with 2-day intervals every 5 doses. Assays were carried out 24 hours after the last dose of exposure.

\subsection{Induction of hypersensitivity reaction}

Rats were sensitized by a single intraperitoneal injection of ovalbumin (OVA, $10 \mu \mathrm{g})$ mixed with aluminum hydroxide $\left(10 \mathrm{mg}\right.$ ) as adjuvant on the $10^{\text {th }}$ day of $\mathrm{HQ}$ or vehicle exposure. Thirteen days later, rats were challenged with OVA administered by inhalation (1\% in PBS; 15 min application using an ultrasonic inhaler). The time frame was chosen based on Coleman et al. (1983), who demonstrated that the levels of circulating immunoglobulin E ( $\operatorname{lgE}$ ) antibodies in rats increases rapidly 7-14 days after intraperitoneal injection with OVA.

\subsection{Bronchoalveolar lavage (BAL) and cell counting}

Animals were anesthetized with ketamine and xilazine and exsanguinated. A cannula was then inserted into the trachea and $20 \mathrm{~mL}(2 \times 10$ $\mathrm{mL}$ ) phosphate-buffered saline (PBS) was injected. Immediately following PBS injection, BAL was collected and the fluid was centrifuged at $500 \times g$ for $10 \mathrm{~min}$ at $4^{\circ} \mathrm{C}$. The cell pellet was re-suspended in $1 \mathrm{~mL}$ of PBS. The number of cells was determined using a Neubauer chamber and stained cell suspensions $(0,5 \%$ crystal violet dissolved in $30 \%$ acetic acid). Differential cell counts were performed from cytospin preparations and then stained with May-Grünwald and Giemsa dyes.

\subsection{Myeloperoxidase activity}

In order to quantify neutrophil infiltration in the lung tissue, we assayed myeloperoxidase activity in lung homogenates. The thorax was cut open and the lungs perfused with saline containing heparine $(5 \mathrm{IU} / \mathrm{mL})$ with PBS $(\mathrm{pH} 7.0)$ via the pulmonary artery. The whole lung was then homogenized using a 
Brinkmann Tissue Homogenizer (Polytron $®)(2 \times 30 \mathrm{~s})$ in $3 \mathrm{~mL} / \mathrm{g}$ of $0.1 \mathrm{M}$ phosphate buffer pH 6.0 containing $0.5 \%$ hexadecyltrimethyl ammonium bromide and $5 \mathrm{mM}$ EDTA. The samples were then sonicated (Vibra Cell-Sonics Materials $\left.{ }^{\circledR}\right)(3 \times 2 \mathrm{~min}, 40 \mathrm{~Hz})$ and centrifuged $(37,000 \mathrm{~g}, 15 \mathrm{~min})$ at $4^{\circ} \mathrm{C}$. Myeloperoxidase activity was assayed in $40 \mu \mathrm{L}$ aliquots of the supernatants by measuring changes in absorbance at $460 \mathrm{~nm}$ resulting from decomposition of $\mathrm{H}_{2} \mathrm{O}_{2}$ in the presence of $\theta$-dianisidine in a final volume of $1.5 \mathrm{~mL}$ as previously described (Henson et al., 1978).

\subsection{Circulating leukocyte number: total and differential}

The number of circulating leukocytes was determined on day 10 of chemical exposure immediately before sensitization, on day13 after sensitization and before challenge, and 24 hours after challenge. The leukocytes were obtained from blood samples from the orbital plexus using heparin $(5 \mathrm{Ul} / \mathrm{mL})$ as anticoagulant. The total number of leukocytes was assessed using a Neubauer chamber. Differential counts were performed on the basis of 100 cells per blood extension stained with May-Grünwald and Giemsa dyes.

\subsection{Endothelial immunohistochemistry}

The lungs were rapidly removed and insufflated with O.C.T. Tissue Tek ${ }^{\mathrm{TM}}$ mounting medium diluted 2:1 with PBS. Regions of the left and right lung lobes were frozen in nitrogen-hexan solution, cryosectioned ( $8 \mu \mathrm{m}$ thickness) and fixed with cold acetone for $10 \mathrm{~min}$. For direct immunohistochemistry, sections were incubated with block solution to block unspecific sites for $24 \mathrm{~h}$ in a humidified atmosphere at $4^{\circ} \mathrm{C}$, followed by an overnight incubation (humidified box, $4^{\circ} \mathrm{C}$ ) with FITC-labeled rat anti-mouse ICAM-1 (1:50) monoclonal antibody, R-PE-labeled mouse anti-rat PECAM-1 (1:500) monoclonal antibody, and R-PE labeled mouse anti-rat VCAM-1 (1:100) monoclonal antibody. The preparations were analysed using an image analysing software (KS 300, Kontron) and 
fluorescence microscopy. To evaluate background reactions, procedures were also performed in sections incubated without antibodies.

\subsection{Blood flow cytometry}

Leukocytes were isolated from blood collected from the orbital plexus (EDTA, $100 \mathrm{mg} / \mathrm{mL}$ ) before and after challenge to quantify L-selectin or $\beta_{2^{-}}$ integrin expression. Briefly, erythrocyte lysis was performed using ammonium chloride solution $(0.13 \mathrm{M})$ and leukocytes were recovered after washing with HBSS. After washing, leukocytes were incubated for 30 minutes at $4^{\circ} \mathrm{C}$ in the dark with $10 \mu \mathrm{L}$ of monoclonal antibody against L-selectin or $\beta 2$ integrin. Immediately after incubation, cells were analysed on a FACScalibur flow cytometer (Becton \& Dickinson - San Jose, CA). Data from 10,000 cells were obtained and only the morphologically viable leukocytes were considered for analysis.

\subsection{Anaphylactic reaction in vitro}

Thirteen days after sensitization, the anaphylactic response in isolated distal tracheal segments was tested in vitro. Rats were killed under deep chloral hydrate anesthesia $(>400 \mathrm{mg} / \mathrm{Kg}$, i.p.) and exsanguinated via the abdominal aorta. The trachea was removed and dissected free of connective tissue. Tracheal rings corresponding to the last 3-5 cartilaginous rings closest to the carine, designated the distal trachea were set up for the measurement of isometric contractions by suspending them with two steel hooks in $8 \mathrm{~mL}$ organ baths containing Krebs-Henseleit solution with the following composition ( $\mathrm{mM}$ ): $\mathrm{NaCl}$ 115.0, $\mathrm{KCl} 4.6, \mathrm{CaCl}_{2} 2 \mathrm{H}_{2} \mathrm{O} 2.5, \mathrm{KH}_{2} \mathrm{PO} 4$ 1.2, $\mathrm{MgSO}_{4} 7 \mathrm{H}_{2} \mathrm{O} 2.5$, $\mathrm{NaHCO}_{3} 25.0$ and glucose 11.0. The solution was gassed with $95 \% \mathrm{O}_{2}$ and $5 \%$ $\mathrm{CO}_{2}$ and maintained at $36^{\circ} \mathrm{C}$. The tissue was allowed to equilibrate for $60 \mathrm{~min}$ under an initial tension of $500 \mathrm{mg}$. During this period, the tension was adjusted to $1.0 \mathrm{~g}$, and the contractile activity of the tissue was then assessed by the addition of iso-osmolar Krebs-bicarbonate solution containing $60 \mathrm{mM} \mathrm{KCl}$. The 
tissue was subsequently challenged by the addition of $\mathrm{AO}$ at final concentration of $100 \mu \mathrm{g} / \mathrm{mL}$.

\subsection{Passive cutaneous anaphylaxis (PCA) reaction}

An IgE-dependent cutaneous reaction was generated by sensitizing the skin of non-manipulated rats with an intradermal injection of diluted serum from vehicle- or HQ-exposed rats and sensitised with OVA. $24 \mathrm{~h}$ later animals received an intravenous injection of $1 \mathrm{~mL}$ of solution containing $500 \mu \mathrm{g}$ OVA and 2,5 mg Evans blue. After $30 \mathrm{~min}$, the rats were sacrificed; the dorsal skin was removed for measurement of the pigmented area. Passive cutaneous anaphylaxis was expressed by PCA title, which represents the greater dilution of sera those induced an tissue reaction with area greater than $5 \mathrm{~mm}$ in diameter.

\subsection{Cell proliferation assays}

Thirteen days after sensitization, the spleen was harvested and $2 \times 10^{5}$ cells per well were cultured in 96-well flat bottom tissue culture plates with 25 to $125 \mu \mathrm{g} / \mathrm{mL}$ of OVA in complete RPMI with $5 \%$ FCS or with concanavalin A $(\mathrm{ConA} ; 7 \mu \mathrm{g} / \mathrm{mL})$. During the last $18 \mathrm{~h}$ of the 4 -day culture period, $\left[{ }^{3} \mathrm{H}\right]$ thymidine was added $(1 \mu \mathrm{Ci} /$ well). At the end of this period of incubation, cells were collected with an automated cell harvester, and incorporated radioactivity was measured by liquid scintillation spectrometry. Data are expressed as mean \pm standard deviation counts per minute of $\left[{ }^{3} \mathrm{H}\right]$ thymidine incorporation.

\subsection{Statistical analysis}

Means and standard errors of means (SEM) of all data are presented and were compared by Student's $t$-test or ANOVA with a significance probability of less than 0.05 . Individual comparisons were subsequently performed with Bonferroni's test for unpaired values and Tukey test. 


\section{Results}

3.1 HQ exposure inhibits leukocyte migration to the allergic inflammatory focus

There were significantly fewer leukocytes present in the bronchoalveolar lavage (BAL) fluid $24 \mathrm{~h}$ after OVA challenge in $\mathrm{HQ}$-exposed rats compared to vehicle-exposed rats (Figure 1A), and differential analysis showed that chemical exposure reduced the influx of both polymorphonuclear (PMN) cells and mononuclear $(\mathrm{MN})$ cells into the bronchoalveolar cavity (Figure 1A). Figure 1B shows the activity of myeloperoxidase in the pulmonary tissue, as an indicative of PMN number in the tissue. A comparison of results from HQ- and vehicleexposed rats shows that the decreased number of PMN in the BAL fluid from $\mathrm{HQ}$-exposed rats is not dependent on its accumulation in the pulmonary tissue (Figure 1B).

\subsection{HQ exposure does not alter the number of circulating leukocytes}

The number of circulating leukocytes was not modified by $\mathrm{HQ}$ exposure, since the amount of total white cells and their subtypes MN and PMN cells of $H Q$ exposure were not different from the values detected in vehicle-exposed rats 10 days after the exposures (Table 1). Similar numbers of cells were also detected after OVA sensitization and challenge in both groups of animals (Table 1).

3.3 HQ exposure does not alter the expression of adhesion molecules involved in pulmonary leukocyte recruitment

Characterization of L-selectin and $\beta 2$ integrin expression on circulating leukocytes showed that $\mathrm{HQ}$ exposure did not change the basal pattern of expression of both molecules on PMN and MN membranes (Figure 2). Twelve hours after OVA challenge, there was a comparable decrease in the expression of L-selectin on PMN and $\mathrm{MN}$ from HQ- and vehicle-exposed rats, and $\beta 2$ integrin expression was not significantly altered on the two types of leukocytes from both groups of animals (Figure 2). Also, the expression of counter- 
receptors for $\beta 2$ integrin on pulmonary endothelial cells was not modified by $\mathrm{HQ}$ exposure even at basal conditions or $12 \mathrm{~h}$ after OVA challenge. The expressions of PECAM-1, ICAM-1 and VCAM-1 were comparable on cells from both groups of animals at basal or OVA-challenge conditions (Figure 3). Figures $3 A$ and $B$ show similar expression of PECAM-1 on the vessel walls of vehicleor $\mathrm{HQ}$-exposed rats, and also confirm the inhibitory effect of $\mathrm{HQ}$ on impairment of leukocyte migration to the pulmonary tissue, since the amount of PECAM-1labeled leukocytes is this tissue is much lower in HQ- exposed rats than in vehicle-exposed animals.

\subsection{HQ exposure reduces tracheal contraction in vitro}

Tracheas obtained from HQ- or vehicle-exposed rats were assayed to investigate their ability of contraction after in vitro OVA challenge. As shown in Figure 4 , the tension developed by tracheas from $\mathrm{HQ}$-exposed rats was significantly lower than that developed by tracheas from vehicle-exposed rats.

\subsection{HQ exposure impairs the production of $\lg E$}

Results depicted in Figure 5 show the ability of sera obtained from $\mathrm{HQ}$ or vehicle-exposed rats to induce an increase in cutaneous permeability in nonmanipulated rats. HQ-exposed rats required higher concentrations of sera than vehicle exposed rats to evoke a pattern of PCA similar to that of the latter, indicating that vehicle-exposed rats presented lower amounts of IgE in their sera.

\subsection{HQ exposure does not alter the proliferation of lymphocytes}

In vitro lymphocyte proliferation in response to OVA or ConA challenge was not altered by $\mathrm{HQ}$ exposure as demonstrated in Figure 6. Lymphocyte proliferation was equivalent in spleen cells collected from $\mathrm{HQ}$ - or vehicleexposed rats. HQ exposure also did not modify the total number of spleen leukocytes in vehicle-exposed rats $\left(\mathrm{HQ}=18,6 \pm 1,7 \times 10^{6} \mathrm{cell} / \mathrm{mL}\right.$; Vehicle 18,6 $\pm 3,1 \times 10^{6} \mathrm{cell} / \mathrm{mL} ; \mathrm{n}=4$ for each group). 


\section{Discussion}

We have shown that in vivo $\mathrm{HQ}$ exposure impairs leukocyte influx into the lungs during an allergic inflammatory reaction. The mechanism involved is dependent on reduced antibody production, which may decrease mast cell degranulation and the beginning of the process.

Allergic asthma is a form of chronic inflammatory response characterized by reversible obstruction of the airways, secretion of inflammatory mediators and airway hyper responsiveness (Rankin et al., 2000; Taube et al., 2003; Bochner, 2004). After exposure to allergens, the airway is infiltrated with a variety of inflammatory cells, including lymphocytes, macrophages, neutrophils and eosinophils, each with a different kinetics of migration. Neutrophils are the first inflammatory cells to accumulate in the airways (Fahy et al., 1995; Koh et al., 1993). This kinetic of leukocyte migration was detected in an experimental model of asthma similar to the one employed (Tomkinson et al. 2001). Our data showed that $\mathrm{HQ}$ exposure is capable of impairing the recruitment of both PMN and $\mathrm{MN}$ cells to the bronchoalveolar cavity in rats sensitized and challenged to OVA. In addition, the reduced PMN migration did not reflect the accumulation of neutrophils, the main PMN cell in rats, in the pulmonary tissue. It was detected comparable low myeloperoxidase activity in pulmonary tissues of both groups of animals studied, indicating that in HQ-exposed rats neutrophils do not even arrive at lung tissues.

In vivo exposure to benzene alters the production and maturation of leukocytes in the bone marrow compartment, which may impair the delivery of white cells to the circulation and/or may alter their specific functions (MacEachern et al., 1992; Farris et al., 1997; Yoon et al., 2001). The importance of $\mathrm{HQ}$ in these effects has been demonstrated after its in vitro addition to cultured precursor cells (King et al., 1987; 1989; Li et al., 1996; 1997; 1998; Pyatt et al., 1998; 2000; McCue et al., 2000; 2003) and in vivo by reducing the number of $\mathrm{B}$ cell progenitors in the spleen and bone marrow of HQ- or catechol-treated mice (Wierda and Irons, 1982). Here we showed that 
HQ- or catechol-treated mice (Wierda and Irons, 1982). Here we showed that our experimental procedure of $\mathrm{HQ}$ exposure did not modify the number of circulating leukocytes or the number of spleen lymphocytes after sensitization, suggesting that the impaired leukocyte migration to inflamed area does not reflect effects of $\mathrm{HQ}$ on leukocytes production and/or their maturation phases.

The possibility that $\mathrm{HQ}$ alters the specific functions involved in the initial phases of leukocyte migration was excluded by the observation that the expression of both L-selectin and $\beta 2$ integrin adhesion molecules was not modified in circulating PMN and MN cells. The reduction in L-selectin expression after OVA challenge was equivalent in cells from both groups of animals studied, and may represent its shedding from cell membranes after the initial rolling to postcapillary venules during the early stages of inflammation (Fors et al., 2001; Venturi et al., 2003; Smalley and Ley, 2005). The expected upregulation of $\beta 2$ integrin expression after OVA challenge was not also detected in cells from both groups of animals. After 12 hours of inflammation other integrins, such as $\beta 1$ and $\beta 7$, may mediate leukocyte migration in pulmonary tissue (Bochner, 2004). However, the similar pattern of expression of selectin and integrin in both groups of animals indicates that $\mathrm{HQ}$ exposure does not induce a different state of leukocyte activation. As observed in leukocytes, $H Q$ exposure also did not modify the expression of endothelial counter-ligand molecules ICAM-1, VCAM-1 and PECAM-1. Interestingly, our data indicate that PECAM-1 can be an important molecule expressed by leukocytes after OVA challenge, given that its expression was detected on white cells present in the pulmonary tissue. In this case, the number of PECAM-1-labeled leukocytes was higher in vehicle-exposed rats than $\mathrm{HQ}$-exposed animals, confirming that $\mathrm{HQ}$ exposure reduces neutrophil numbers in the pulmonary tissue.

In allergic asthma, IgE-activated mast cells secrete endogenous mediators, which are capable of producing smooth muscle contraction in the airways, including arachidonic acid metabolites, histamine and 5hydroxytryptamine (Shin et al., 2000; Bochner, 2004). Here we showed that isolated tracheal segments from $\mathrm{HQ}$-exposed rats did not respond to the in vitro 
of mast cells to degranulate in response to OVA-IgE. Data from previous study, where we employed similar experimental protocol, but in absence of immunological sensitization, may exclude these possibilities. $\mathrm{HQ}$ exposure did not alter the number of mast cells or their ability to degranulate in response to $48 / 80$ compound (Macedo et al., 2006). Additional data here presented suggest that the inhibitory effect of $\mathrm{HQ}$ is dependent on IgE production, since serum from HQ-exposed rats produced an ineffective response to OVA in nonmanipulated rats. This was demonst ed by inducing the IgE-dependent cutaneous reaction, a typical model to measure IgE levels (Shin et al., 2000; Hong et al., 2003). The reduced production of IgE seems to be independent on antigen presentation or the ability of lymphocytes to proliferate, given that our in vitro assays showed that the proliferation of spleen lymphocytes in response to OVA was equivalent in cells from vehicle- or HQ-exposed rats. Additionally, a similar response to Con $A$ indicates that spleen lymphocytes maintain intact the intracellular mechanisms of proliferation. In contrast to these data, results from other groups obtained in in vitro assays have demonstrated that $\mathrm{HQ}$ impairs lymphocyte proliferation and activation by different mechanisms. For instance, it has been proposed that $\mathrm{HQ}$ inhibits progression of the cell cycle ( $\mathrm{Li}$ et al, 1996, 1997; McCue et al., 2003) and the activity of ribonucleotide reductase (Li et al., 1998; McCue et al., 2000), consequently blocking lymphocyte proliferation. It has also been shown that $\mathrm{HQ}$ reduces IL-2 and TNF production by $\mathrm{T}$ and $\mathrm{B}$ cells, respectively, in a mechanism dependent on NF-kappa B in response to various stimuli (Pyatt et al., 1998, 2000).

$H Q$ may differently affect the chemical mediation of $B$ lineage production and functions, depending on its phases of maturations and cell activation state. In vitro assay using murine bone marrow cell suspension showed that $\mathrm{HQ}$ blocks the final maturation stages of $B$ cells differentiation, generating reduced number of mature cells. The mechanism proposed is toxicity of regulatory cells involved in the process (king et al., 1987). Complementary assays demonstrated that the effect was dependent, at least in part, on inhibition of IL-4 production by fibroblast stromal cells and by IL-1 secretion by macrophages 
production by fibroblast stromal cells and by IL-1 secretion by macrophages (King et al., 1989). Differently, Lee et al. (2002) showed that HQ significantly increased IL-4 production in murine keyhole limpet haemocyanin (KLH)-primed $\mathrm{CD} 4^{+} \mathrm{T}$ cells in vitro. The effect was in vivo corroborated by elevated levels of $\lg \mathrm{E}$ after $\mathrm{HQ}$ exposure in sensitized mice.

Despite the complexity of controlling IgE B-cell differentiation, down regulating IgE levels can be achieved by bypassing the cytokine regulatory circuits, such as IL-4, IL-13, and CD40 (Chen et al., 2005). Therefore, we expect that the in vivo $\mathrm{HQ}$ exposure here employed may impair the cell signalling for B-cell differentiation and IgE production, with consequent immunosuppressive activity. This possibility will be further investigated to elucidate the mechanisms involved on the inhibitory effect of $\mathrm{HQ}$ on IgE production here proposed.

Together, our data clearly show that in vivo $H Q$ exposure, for an extended period of time, which can be addressed in an occupational or environmental exposure, may lead to an inability of allergic response, as measured here by impairment on leukocyte mobilization.

Acknowledgement: This work was supported by FAPESP grants \#03/04013-8. Suéllen Cristine Moreira Vaz is FAPESP fellow undergraduate student (\#05/55623-6) and S.M.D. Macedo is graduate fellow supported by Capes. S.H.P. Farsky and W.Tavares de Lima are fellow of the Conselho Nacional de Pesquisa e Tecnologia (CNPq). 


\section{References}

Ansel, K.M., Lee, D.U., Rao, A. (2003). An epigenetic view of helper T cell differentiation. Nat. Immunol. 4(7), 616-623.

Bice, D.E., Seagrave, J., Green, F.H. (2000). Animal models of asthma: potential usefulness for studying health effects of inhaled particles. Inhal. Toxicol. 12(9), 829-862.

Bochner, B.S. (2004). Adhesion molecules as therapeutic targets. Immunol. Allergy Clin. North. Am. 24(4), 615-630.

Careau, E., Sirois, J., Bissonnette, E.Y. (2002). Characterization of lung hyperresponsiveness, inflammation, and alveolar macrophage mediator production in allergy resistant and su ptible rats. Am. J. Respir. Cell Mol. Biol. 26(5), 579-586.

Chen, S.S., Gong, J., Yang, Y.M., Oettgen, H., Zanetti, M. (2005). Cytotoxic Tcells specific for natural $\lg$ E peptides downregulate $\operatorname{lgE}$ production. Cell. Immunol. 233(1), 11-22.

Coleman, J.W., Layton, G.T., Stanworth, D.R. (1983). The kinectics of in vivo sensitization of rat peritoneal and lung mast cells: temporal dissociation from circulating levels of IgE. Eur. J. Immunol. 13(12), 994-998.

DeCaprio, A.P. (1999). The toxicology of hydroquinone - Relevance to occupational and environmental exposure. Crit. Reviews in Toxicol. 29(3), 283-330. 
Fahy, J.V., Kim, K.W., Liu, J., Boushey, H.A. (1995). Prominent neutrophilic inflammation in sputum from subjects with asthma exacerbation. J. Allergy Clin. Immunol. 95(4), 843-852.

Farris, G.M., Robinson, S.M., Gaido, K.W., Wong, B.A., Wong V.A., Hahn, W.P, Shah, R.S. (1997). Benzene-induced hematotoxicity and bone marrow compensation in B6C3F1 mice. Fundam. Appl. Toxicol. 36(2), 119-129.

Fors, B.P., Goodarzi, K., von Andrian, U.H. (2001). L-selectin shedding is independent of its subsurface structures and topographic distribution. J. Immunol. 167(7), 3642-3651.

Grayson, M.H., Van der Vieren, M., Sterbinsky, S.A., Gallantin, W.M., Hoffman, P., Staunton, D., Bochner, B.S. (1999). $\alpha \mathrm{d} \beta 2$ integrin is a ligand for vascular cell adhesion molecule-1. Int. Arch. Allergy Immunol. 118(2-4), 263-264.

Goldstein, B.D., Snyder, C.A., Laskin, S., Bromberg, I., Albert, R.E., Nelson, N. (1982). Myelogenous leukemia in rodents inhaling benzene. Toxicol. Lett., 13(3-4), 169-173.

Guo, Y., Heqvist, P., Gustafsson, L.E. (2001). Absence of mast cell involvement in active systemic anaphylaxis in rats. Eur. J. Pharmacol. 430, 305-310.

Henderson, R. F. (1996). Species differences in the metabolism of benzene. Environ. Health Perspect. 104(Suppl 6), 1173-1175.

Henschler, R., Glatt, H.R., Heyworth, C.M. (1996). Hydroquinone stimulates granulocyte-macrophage progenitor cells in vitro and in vivo. Environ. Health Perspect. 104(Suppl.6), 1271-1274. 
Henson, P., Zanolary, B., Schwartzman, N.A., Hong, S. (1978). Intracellular control of human neutrophil secretion. J. Immunol. 121(3), 851-855.

Hoffmann, D., Hecht, S.S., Wynder, E.L. (1983). Tumor promoters and cocarcinogens in tobacoo carcinogenesis. Environ. Health Perspect. 50, 247-257.

Hong, S.H., Jeong, H.J., Kim, H.M. (2003). Inhibitory effects of Xanthii fructus extract on mast cell-mediated allergic reaction in murine model. J. Ethnopharmacol. 88(2-3), 229-234.

Kikuchi, M., Tachimoto, H., Nutku, E., Hudson, S.A., Bochner, B.S. (2003). Phorbol esters $\alpha 4$ and $\alpha \mathrm{d}$ integrin usage during eosinophil adhesion to VCAM-1. Cell Commun. Adhes. 10(3), 119-128.

Kim, J., McKinley, L., Siddiqui, J., Bolgos, G.L., Remick, D.G. (2004). Prevention and reversal of pulmonary inflammation and airway hyperresponsiveness by dexamethasone treatment in a murine model of asthma induced by house dust. Am. J. Physiol. Lung Cell Mol. Physiol. 287(7), L503-L509.

King, A.G., Landreth, K.S., Wierda, D. (1987). Hydroquinone inhibits bone marrow pre-B cell maturation in vitro. Mol. Pharmacol. 32(6), 807-812.

King, A.G., Landreth, K.S., Wierda, D. (1989). Bone marrow stromal cell regulation of B-lymphopoiesis. II. Mechanisms of hydroquinone inhibition of pre-B cell maturation. J Pharmacol. Exp. Ther. 250(2), 582-590. 
Koh, Y.Y., Dupuis, R., Pollice, M., Albertine, K.H., Fish, J.E., Peters, S.P. (1993). Neutrophils recruited to the lungs of humans by segmental antigen challenge display a reduced chemotactic response to leukotriene B4. Am. J. Respir. Cell Mol. Biol. 8(5), 493-499.

Kolachana, P., Subrahmanyam, V.V., Meyer, K.B., Zhang, L., Smith, M.T. (1993). Benzene and its phenolic metabolites produce oxidative DNA damage in HL60 cells in vitro and in the bone marrow in vivo. Cancer Res. 53, 1023-1026.

Kubes, P., Kerfoot, S.M. (2001). Leukocyte recruitment in the microcirculation: the rolling paradigm revisited. News Physiol. Sci. 16, 76-80.

Lazaar, A.L., Panettieri, R.A. (2005). Airway smooth muscle: A modulator of airway remodeling in asthma. J. Allergy Clin. Immunol. 116(3), 488-495.

Lee, M.H., Chung, S.W., Kang, B.Y., Kim, K.M., Kim, T.S. (2002). Hydroquinone, a reactive metabolite of benzene, enhances interleukin-4 production in CD4+ $T$ cells and increases immunoglobulin $E$ levels in antigenprimed mice. Immunology 106(4):496-502.

Leung, S.Y., Eynott, P., Noble, A., Nath, P., Chung, K.F. (2004). Resolution of allergic airways inflammation but persistence of airway smooth muscle proliferation after repeated allergen exposures. Clin. Exp. Allergy 34, 213220.

Li, Q., Geiselhart, L., Mittler, J.N., Mudzinski, S.P., Lawrence, D.A., Freed, B.M. (1996). Inhibition of human T lymphoblast proliferation by hydroquinone. Toxicol. Appl. Pharmacol. 139(2), 317-323. 
Li, Q., Aubrey, M.T., Christian, T., Freed, B.M. (1997). Differential inhibition of DNA synthesis in human $T$ cells by the cigarette tar components hydroquinone and catechol. Fundam. Appl. Toxicol. 38(2), 158-165.

Li, Q., Kasten-Jolly, J., Yen, Y., Freed, B.M. (1998). Reversal of hydroquinonemediated suppression of T cell proliferation by transfection of the M2 subunit of ribonucleotide reductase. Toxicol. Appl. Pharmacol. 150(1), 154-157.

MacEachern, L., Snyder, R., Laskin, D.L. (1992). Alterations in the morphology and functional activity of bone marrow phagocytes following benzene treatment of mice. Toxicol. Appl. Pharmacol. 117(2), 147-154.

Macedo, S.M.D., Lourenço, E.L.B., Borelli, P., Fock, R.A., Ferreira Jr., J.M., Farsky, S.H.P. (2006). Effect of in vivo phenol or hydroquinone exposure on events related to neutrophil delivery during an inflammatory response. Toxicology, in press.

McCue, J.M., Link, K.L., Eaton, S.S., Freed, B.M. (2000). Exposure to cigarette tar inhibits ribonucleotide reductase and blocks lymphocyte proliferation. J. Immunol. 165(12), 6771-6775.

McCue, J.M., Lazis, S., Cohen, J.J., Modiano, J.F., Freed, B.M. (2003). Hydroquinone and catechol interfere with $T$ cell cycle entry and progression through the G1 phase. Molecular Immunol. 39(16), 995-1001.

Miller, M., Sung, K.L., Muller, W.A., Cho, J.Y., Roman, M., Castaneda, D., Nayar, J., Condon, T., Kim, J., Sriramarao, P., Broide, D. H. (2001). Eosinophil tissue recruitment to sites of allergic inflammation in the lung is platelet endothelial cell adhesion molecule independent. J. Immunol. 167(4), 2292-2297. 
Miyasaka, C.K., Mendonça, J.R., Silva, Z.L., de Sousa, J.A.A., Tavares de Lima, W., Curi, R. (1999). Modulation of hypersensitivity reaction by lipids given orally. General Pharmacol. 32(5), 597-602.

Murphy, K.M., Reiner, S.L. (2002). The lineage decisions of helper T cells. Nat. Rev. Immunol. 2(12), 933-944.

Pascual, R.M., Peters, S.P. (2005). Airway remodeling contributes to the progressive loss of lung function in asthma: an overview. J. Allergy Clin. Immunol. 116(3):477-486.

Pyatt, D.W., Stillman, W.S., Irons, R.D. (1998). Hydroquinone, a reactive metabolite of benzene, inhibits NFKB in primary human CD4+ T lymhocytes. Toxicol. Appl. Pharmacol. 149(2), 178-184.

Pyatt, D.W., Yang, Y., Stillman, W.S., Cano, L.L., Irons, R.D. (2000). Hydroquinone inhibits PMA-induced activation of $\mathrm{NFKB}$ in primary human CD19+ B lymphocytes. Cell Biol. Toxicol. 16(1), 41-51.

Rankin, S.M., Conroy, D.M., Williams, T.J. (2000). Eotaxin and eosinophil recruitment: implications for human disease. Mol. Med. Today 6(1), 20-27.

Schlosser, M.J., Kalf, G.F. (1989). Metabolic activation of hydroquinone by macrophage peroxidase. Chem. Biol. Interact. 72(1-2), 191-207.

Schlosser, M.J., Shumira, R.D., Kalf, G.F. (1990). Prostaglandin H synthase catalyzed oxidation of hydroquinone to a sulfhydryl-binding and DNAdamaging metabolite. Chem. Res. Toxicol. 3(4), 333-339. 
Schrenk, D., Orzechowski, A., Schwarz, L. R., Snyder, R., Burchell, B., Ingelman-Sundberg, M., Bock, K. W. (1996). Phase II metabolism of benzene. Environ. Health Perspect. 104(Suppl6), 1183-1188.

Shin, H.Y., Lee, C.S., Chae, H.J., Kim, H.R., Baek, S.H., An, N.H., Kim, H.M. (2000). Inhibitory effect of anaphylactic shock by caffeine in rats. Int. J. Immunopharmacol. 22(6), 411-418.

Smalley, D.M., Ley, K. (2005). L-selectin: mechanisms and physiological significance of ectodomain cleavage. J. Cell Mol. Med. 9(2), 255-266.

Snyder, R. (2000). Overview of the toxicology of benzene. J. Toxicol. Environ. Health A 61(5-6), 339-346.

Snyder, R. (2002). Benzene and Leukemia. Crit. Rev. Toxicol. 32(3), 155-210.

Snyder, R. (2004). Xenobiotic metabolism and the mechamism(s) of benzene toxicity. Drug Metab. Rev. 36(3-4), 531-547.

Tachimoto, H., Ebisawa, M., Bochner, B.S. (2002). Cross-talk between integrins and chemokines that influences eosinophil adhesion and migration. Int. Arch. Allergy Immunol. 128 (suppl 1), 18-20.

Taube, C, Dakhama, A., Takeda, K., Nick, J.A., Gelfand, E.W. (2003). Allergen-specific early neutrophil infiltration after allergen challenge in a murine model.

Chest 123(Suppl 3), 410S-411S. 
Tavares de Lima, W., da Silva, Z.L. (1998). Contractile response of proximal and distal trachea segments isolated from rats subjected to immunological stimulation: role of connective tissue mast cells. General Pharmacol. 30(5), 689-695.

Tomkinson, A., Duez, C., Cieslewicz, G., Gelfand, E.W. (2001). Eotaxin-1deficient mice develop airway eosinophilia and airway hyperresponsiveness.

Int. Arch. Allergy Immunol. 126(2), 119-125.

Vaporciyan, A.A., DeLisser, H.M., Yan, H.C., Mendiguren, I.I., Thom, S.R., Jones, M.L., Ward, P.A., Albelda, S.M. (1993). Involvement of plateletendothelial cell adhesion molecule-1 in neutrophil recruitment in vivo. Science 262(5139), 1580-1582.

Venturi, G.M., Tu, L., Kadomo, T., Khan, A.I., Fujimoto, Y., Oshel, P., Bock, C.B., Miller, A.S., Albrecht, R.M., Kubes, P., Steeber, D.A., Tedder, T.F. (2003). Leukocyte migration is regulated by L-selectin endoproteolytic release.

Immunity 19(5), 713-724.

von Andrian, U.H., Mackay, C.R. (2000). T-cell function and migration. N. Engl. J. Med. 343(14), 1020-1034.

Wierda, D., Irons, R.D. (1982). Hydroquinone and catechol reduce the frequency of progenitor B lymphocytes in mouse spleen and bone marrow. Immunopharmacology 4(1), 41-54. 
Yoon, B.I., Hirabayashi, Y., Kawasaki, Y., Kodama, Y., Kaneto, T., Kim, D.Y., Inoue, T. (2001). Mechanism of action of benzene toxicity: cell cycle suppression in hemopoietic progenitor cells (CFU-GM). Exp. Hematol. 29(3), 278-285.

\section{Legends for figures}

Figure 1: Number of leukocytes in the BAL fluid $(A)$ from rats exposed to vehicle or $\mathrm{HQ}(50 \mathrm{mg} / \mathrm{Kg}$; i.p. route; once a day; 16 doses with a two-day interval after every five doses). The BAL fluid was obtained 24 hours after OVA challenge and quantification of cells was carried out in a Neubauer chamber with stained cell suspensions ( $0.5 \%$ crystal violet dissolved in $30 \%$ acetic acid). Differential cell counts $(\mathrm{MN}=$ mononuclear; $\mathrm{PMN}=$ polymorphonuclear) were performed from cytospin preparation and then stained with May-Grünwald. Myeloperoxidase activity (B) was assessed in lung homogenates from both groups of rats. The supernatants of homogenates were assayed with $\mathrm{H}_{2} \mathrm{O}_{2}$ in the presence of $\theta$-dianisidine and absorbance was assessed at $460 \mathrm{~nm}$. Results are expressed as mean \pm s.e.m. of samples collected from 4 animals in each group. Assays were performed in duplicate. ${ }^{*} p<0.001$ vs values obtained on vehicle-exposed rats.

Figure 2: Leukocyte adhesion molecule expression on peripheral polymorphonuclear (PMN) and mononuclear (MN) cells obtained from vehicleand $\mathrm{HQ}$-exposed rats $(50 \mathrm{mg} / \mathrm{Kg}$; i.p. route; once a day; 16 doses with a two-day interval after every five doses). Leukocytes were obtained from blood samples collected from the orbital plexus. L-selectin or $\beta_{2}$ integrin expression was quantified before and after 12 hours OVA challenge by blood flow cytometry. Results are expressed as mean \pm s.e.m. of samples collected from 4 animals in each group. Assays were performed in duplicate. ${ }^{*} p<0.001$ vs values obtained on before challenge. 
Figure 3: Endothelium adhesion molecule expression in lungs obtained from vehicle- and $\mathrm{HQ}$-exposed rats $(50 \mathrm{mg} / \mathrm{Kg}$; i.p. route; once a day; 16 doses with a two-day interval after every five doses). PECAM-1, ICAM-1 or VCAM-1 expressions were quantified before and after 12 hours of OVA challenge by immunohistochemistry. Results are expressed as mean \pm s.e.m. of tissues collected from 3 animals in each group. PECAM-1 expression on migrated leukocytes and postcapillary vessels from vehicle- $(A)$ or $\mathrm{HQ}$-exposed rats (B) are represented. Arrows show an individual leukocyte interacted to vessel wall and migrated to the tissue. Assays were performed in duplicate.

Figure 4: In vitro anaphylactic response in isolated distal tracheal segments from vehicle- and $\mathrm{HQ}$-exposed rats $(50 \mathrm{mg} / \mathrm{Kg}$; i.p. route; once a day; 16 doses with a two-day interval after every five doses). The tracheal segment was set up for the measurement of isometric contractions by suspending them with two steel hooks in Krebs-Henseleit solution (gassed with 95\% $\mathrm{O}_{2}$ and 5\% $\mathrm{CO}_{2}$; maintained at $36^{\circ} \mathrm{C}$ ). The contractile activity of the tissue was assessed by the addition of iso-osmolar Krebs-bicarbonate solution containing $60 \mathrm{mM} \mathrm{KCl}$ and subsequently challenged by addition of OVA at final concentration of 100 $\mu \mathrm{g} / \mathrm{mL}$. Results are expressed as mean \pm s.e.m. of tracheas collected from 4 animals in each group. Assays were performed in duplicate. ${ }^{*} p<0.001$ vs values obtained on vehicle-exposed rats.

Figure 5: Passive cutaneous anaphylaxis (PCA) reaction on skin of nonmanipulated animals sensitised with an intradermal injection of diluted serum obtained from vehicle or $\mathrm{HQ}$-exposed rats $(50 \mathrm{mg} / \mathrm{Kg}$; i.p. route; once a day; 16 doses with a two-day interval after every five doses) sensitised with OVA. 24 after i.d. injections, animals were intravenous challenged with OVA solution. Evans blue intravenous injection was carried out as a dye. 30 min later, the dorsal skin was removed for measurement of the pigment area. Passive cutaneous anaphylaxis was expressed by PCA title that represents the greater dilution of sera those induced an area greater than $5 \mathrm{~mm}$ in diameter. Results 
are expressed as mean \pm s.e.m. of samples collected from 4 animals in each group. Assays were performed in duplicate. ${ }^{*} p<0.001$ vs values obtained on vehicle-exposed rats.

Figure 6: In vitro proliferation of spleen lymphocytes from vehicle- and $\mathrm{HQ}$-exposed rats $(50 \mathrm{mg} / \mathrm{Kg}$; i.p. route; once a day; 16 doses with a two-day interval after every five doses). $2 \times 10^{5}$ cells were cultured per well with 25 to $125 \mu \mathrm{g} / \mathrm{mL}$ of OVA or with Concanavalin A (ConA; $7 \mu \mathrm{g} / \mathrm{mL}$ ). During the last 18 $\mathrm{h}$ of the 4-day culture period, $\left[{ }^{3} \mathrm{H}\right]$ thymidine was added $(1 \mu \mathrm{Ci} /$ well). At the end of this period of incubation, cells were collected with an automated cell harvester, and incorporated radioactivity was measured by liquid scintillation spectrometry. Data are expressed as mean \pm s.e.m. counts per minute of $\left[{ }^{3} \mathrm{H}\right]$ thymidine incorporation in cells obtained from 3 animals in each group. Assays were performed in triplicate. ${ }^{*} p<0.001$ vs basal values. 
GLÓRIA DE SOUZA, M.; CAVRIANI, G.; LIGEIRO-OLIVEIRA, A.P.; ALMEIDA, S.R.; TAVARES DE LIMA, W.; FARSKY, S.H.P. In vivo hydroquinone exposure inhibits leukocyte migration during an allergic lung inflammation in rats. Toxicology and Applied Pharmacology, enviado para publicação.

A

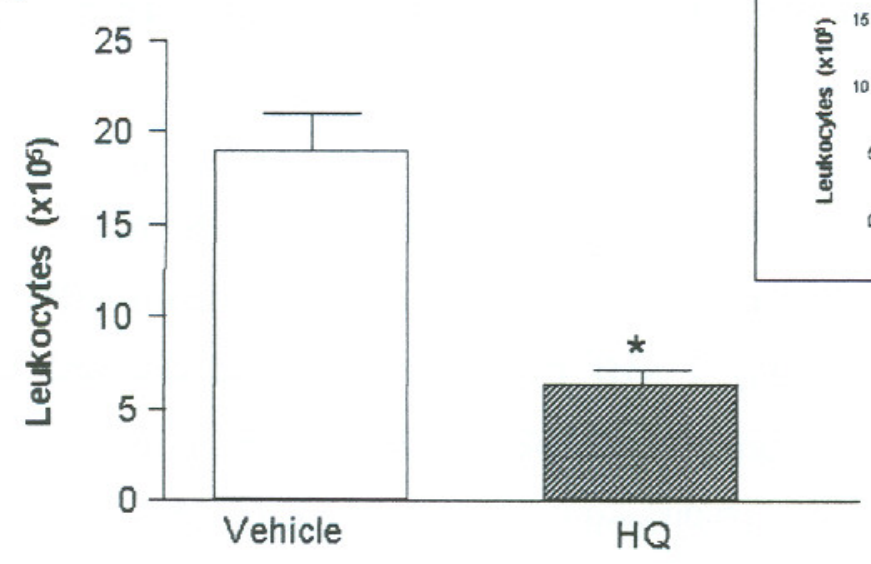

B

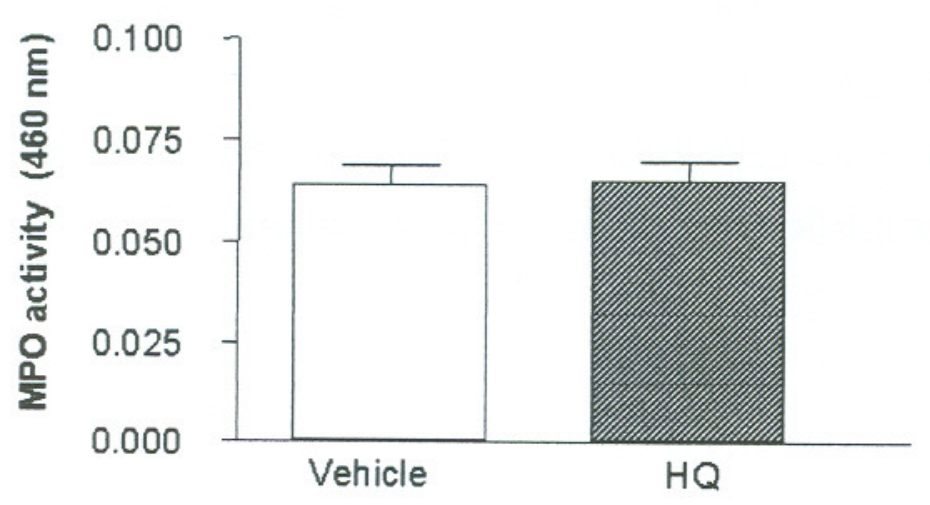

Figure 1 


\section{L-selectin}

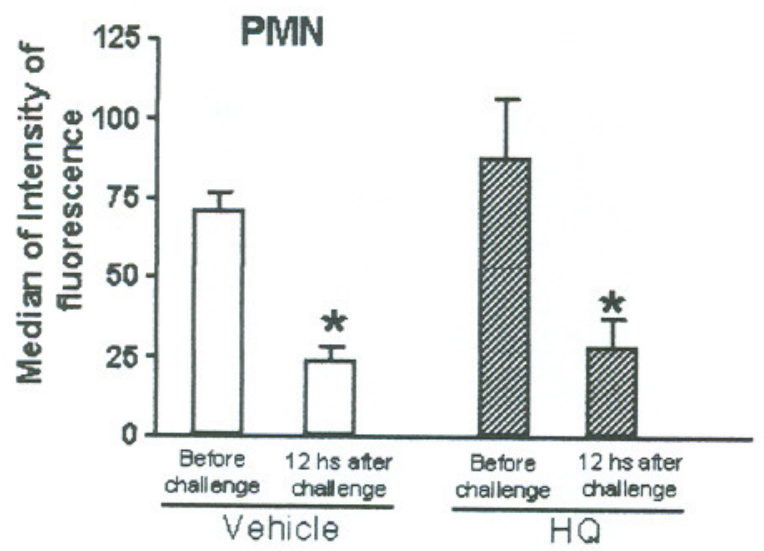

\section{$\beta_{2}$ integrin}

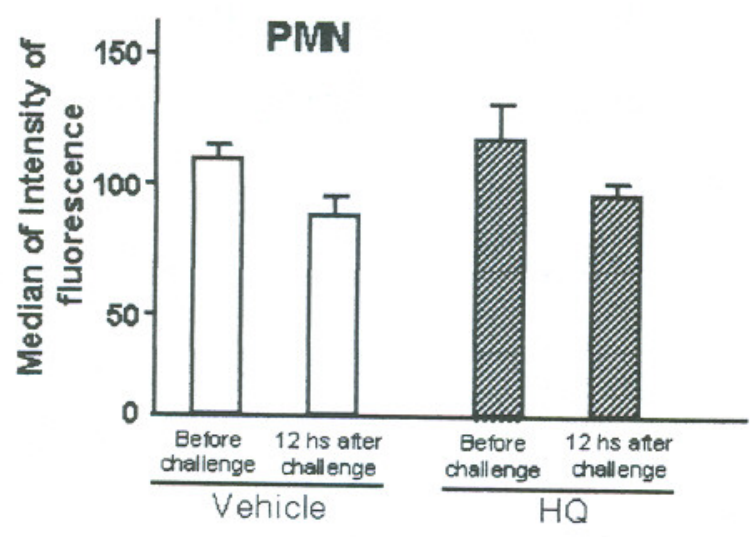

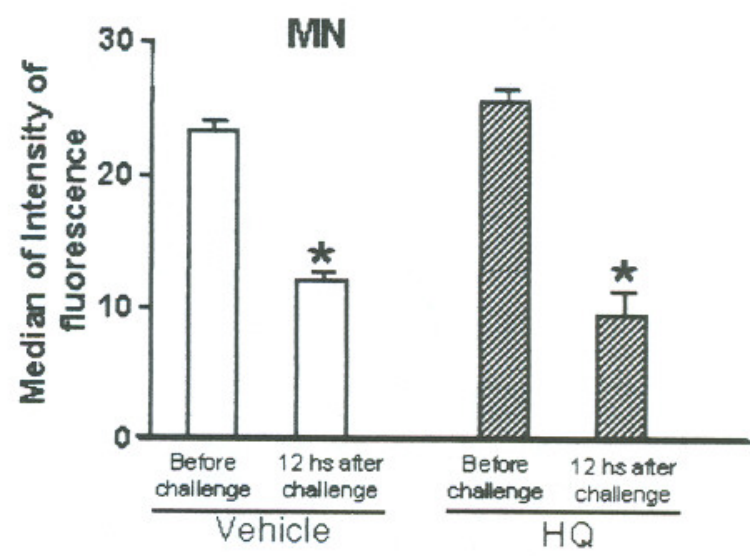

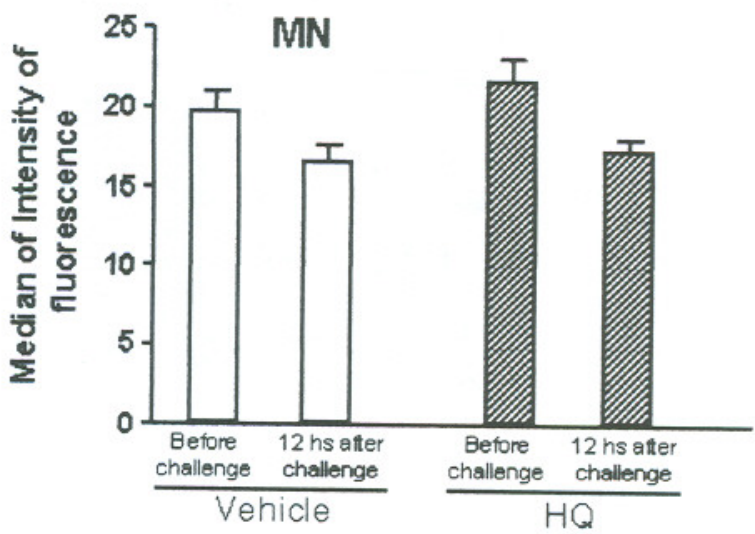

Figure 2 

GLÓRIA DE SOUZA, M.; CAVRIANI, G.; LIGEIRO-OLIVEIRA, A.P.; ALMEIDA, S.R.; TAVARES DE LIMA, W.; FARSKY, S.H.P. In vivo hydroquinone exposure inhibits leukocyte migration during an allergic lung inflammation in rats. Toxicology and Applied Pharmacology, enviado para publicação.
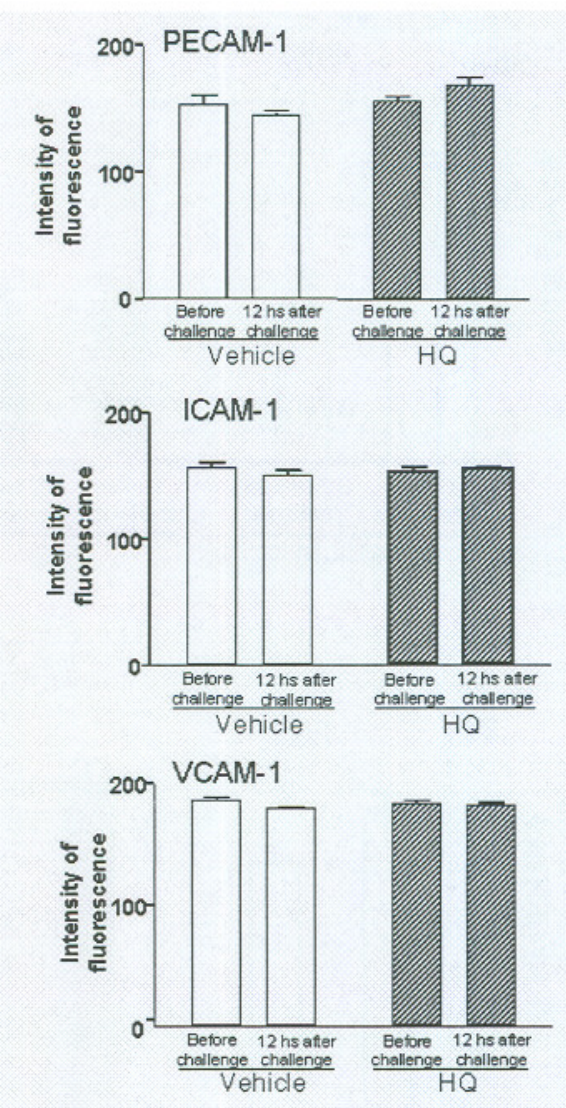
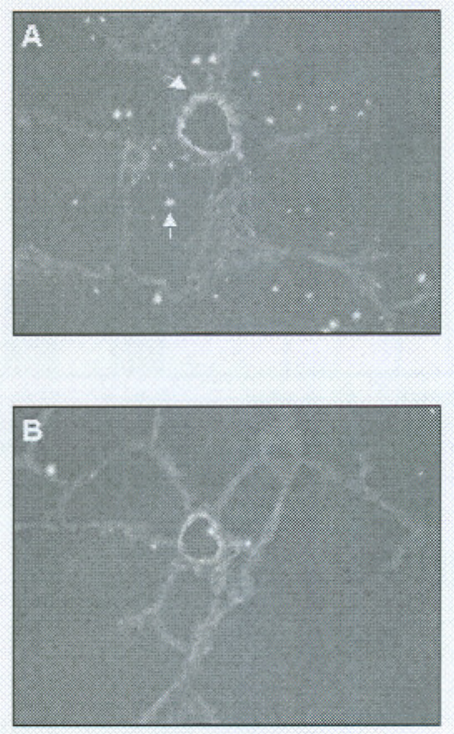

Figure 3 
Anexo 8. Trabalho apresentado: MACEDO, S.M.D; VAZ, S.C.M.; LOURENÇO, E.L.B.; DA

GLÓRIA DE SOUZA, M.; CAVRIANI, G.; LIGEIRO-OLIVEIRA, A.P.; ALMEIDA, S.R.; TAVARES DE LIMA, W.; FARSKY, S.H.P. In vivo hydroquinone exposure inhibits leukocyte migration during an allergic lung inflammation in rats. Toxicology and Applied Pharmacology, enviado para publicação.

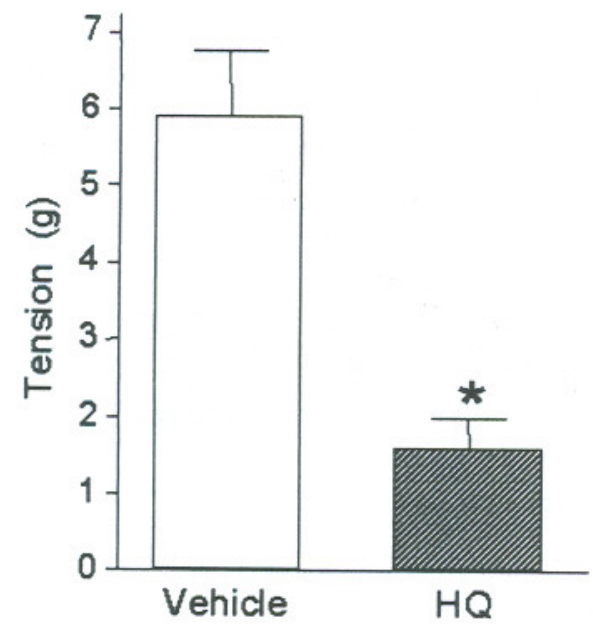

Figure 4

Farsky, S. H. P. 


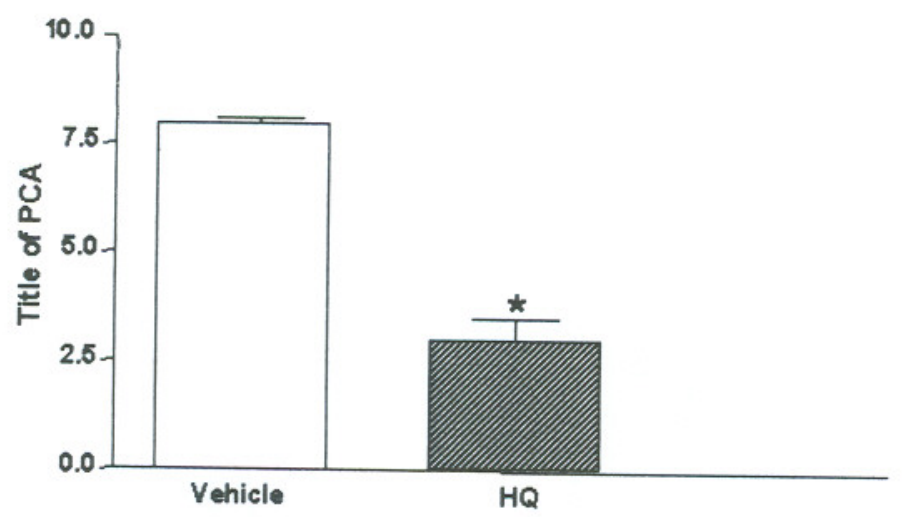

Figure 5

Farsky, S. H. P. 
Anexo 8. Trabalho apresentado: MACEDO, S.M.D; VAZ, S.C.M.; LOURENÇO, E.L.B.; DA GLÓRIA DE SOUZA, M.; CAVRIANI, G.; LIGEIRO-OLIVEIRA, A.P.; ALMEIDA, S.R.; TAVARES DE LIMA, W.; FARSKY, S.H.P. In vivo hydroquinone exposure inhibits leukocyte migration during an allergic lung inflammation in rats. Toxicology and Applied Pharmacology, enviado para publicação.

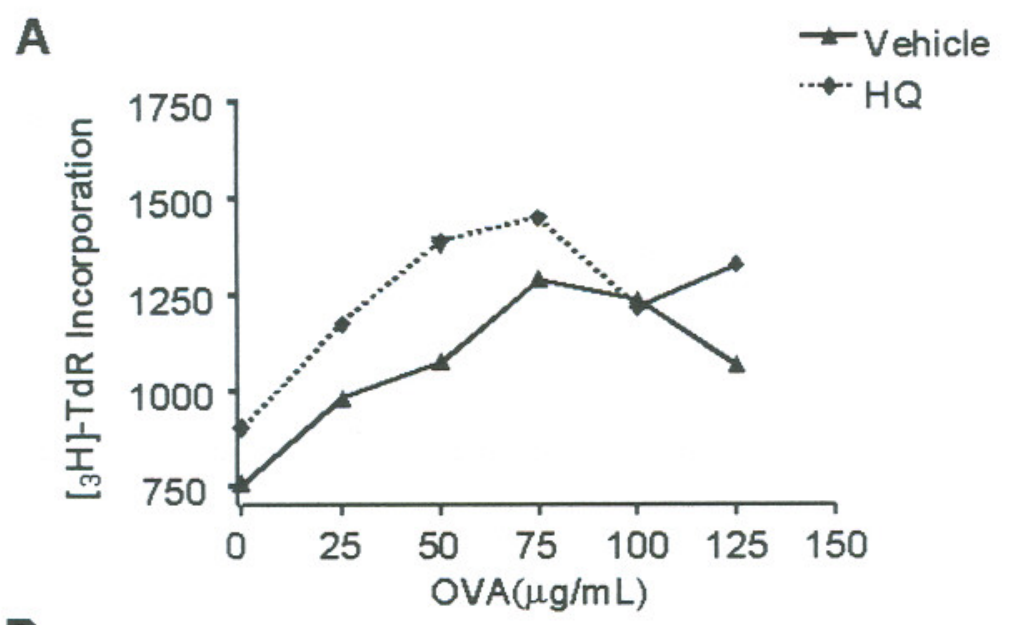

B

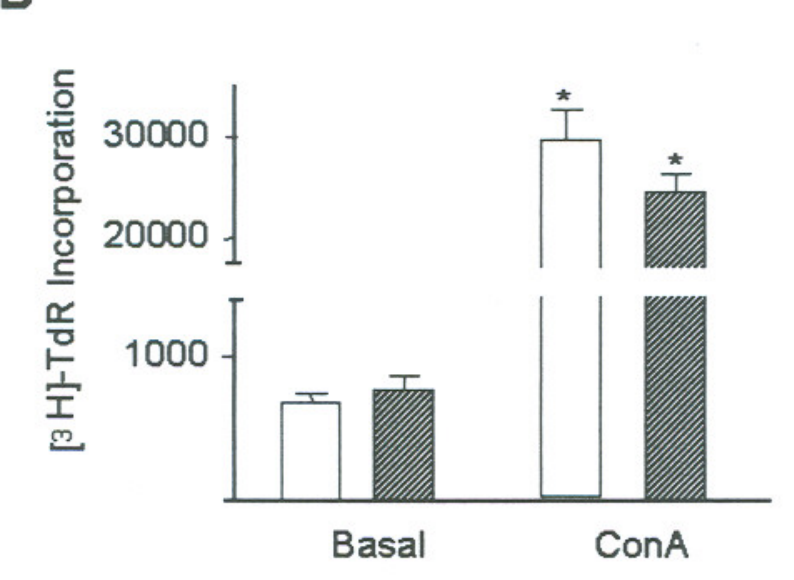

$\square$ Vehicle

שूA $\mathrm{HQ}$

Figure 6 

GLÓRIA DE SOUZA, M.; CAVRIANI, G.; LIGEIRO-OLIVEIRA, A.P.; ALMEIDA, S.R.; TAVARES DE LIMA, W.; FARSKY, S.H.P. In vivo hydroquinone exposure inhibits leukocyte migration during an allergic lung inflammation in rats. Toxicology and Applied Pharmacology, enviado para publicação.

Table 1. Number of circulating leukocytes in rats exposed to $H Q$ or vehicle. Blood was collected from orbital plexus on day 10 of exposures, before and after OVA challenge.

\begin{tabular}{|c|c|c|c|c|c|c|}
\hline & \multicolumn{2}{|c|}{$\begin{array}{c}10^{\text {th }} \text { day of vehicle or } \mathrm{HQ} \\
\text { exposure and } \\
\text { before OVA sensitization }\end{array}$} & \multicolumn{2}{|c|}{$13^{\text {th }}$ day after OVA } & \multicolumn{2}{|c|}{$24 \mathrm{~h}$ after OVA challenge } \\
\hline & Vehide & $\mathrm{HQ}$ & Vehicle & $\mathrm{HQ}$ & Vehicle & $\mathrm{HQ}$ \\
\hline Total & $5686 \pm 293$ & $5557 \pm 452$ & $6186 \pm 331$ & $6240 \pm 559$ & $5610 \pm 451$ & $5433 \pm 465$ \\
\hline MN & $4893 \pm 307$ & $4678 \pm 429$ & $5045 \pm 301$ & $5063 \pm 480$ & $4646 \pm 398$ & $4379 \pm 400$ \\
\hline PMN & $793 \pm 112$ & $879 \pm 87$ & $1141 \pm 83$ & $1177 \pm 83$ & $964 \pm 154$ & $1054 \pm 185$ \\
\hline
\end{tabular}

Data represent mean \pm s.e.m. of 5 animals in each group. 